\title{
Jesuit Art
}

\section{Part 1: Introduction}

\subsection{Jesuit Art}

What is Jesuit art? ${ }^{1}$ A person could answer: objects made by and for Jesuits; the decoration of Jesuit churches; or simply the physical remnants of the Society of Jesus, from the confirmation of the order by Pope Paul III (14681549, r.1534-49) on September 27, 1540 to its suppression by Pope Clement XIV (1705-74, r.1769-74) on July 21, 1773. None of these definitions would be wrong, but they fail to do justice to its extraordinary breadth. In fact, the category "Jesuit art" has been used to encompass objects made by Jesuit artists and workshops, commissioned by Jesuit patrons, closely associated with Jesuit devotion, transported by Jesuits, and merely focused on Jesuit-related subject matter. It ranges from the dizzying heights of monumental church architecture and decoration to ephemeral engravings, bridging European and

1 This book was written during the CoviD-19 pandemic, and a sincere apology must be offered to the reader for places where the impact of closed museums and libraries could not be avoided. The silver lining of this challenging period has been the heroic staff at these institutions, who consistently bent over backwards to accommodate requests despite straitened circumstances. I am particularly indebted to the Bibliothèque Royale de Belgique in Brussels, who kindly allowed this volume to be illustrated with so many of their fine holdings. Truly even a modest book takes a village to bring into production, and some exceptionally generous colleagues moved heaven and earth to aid in procuring critical imagery, without which the argument would be substantially weakened: Karen Bowen, Mauro Brunello, Marinda Chan, Peter van der Coelen, Zeno Colantoni, Ralph Dekoninck, Renzo De Luca, s.J., John Endres, s.J., Edward Fassett, s.J., Pierre Antoine Fabre, Eduardo Fernández, s.J., Christine Göttler, Nanyan Guo, Daan van Heesch, Kayo Hirakawa, Guy Lazure, Huigen Leeflang, Marjolein Leesberg, Francis X. McAloon, s.J., Inêz Correia de Matos, Walter Melion, Teresa Morna, Nadine Orenstein, Luis Gordo Peláez, Luísa Penalva, Rosario Taormina, s.J., António Trigueiros, s.J., Alessandro Vasari, Everlyne Verheggen, Tristan Weddigen, and Steffen Zierholz. I would also like to express my deep appreciation to the anonymous peer reviewers of this manuscript for their meticulous and thoughtful reading of the text, and to Robert Maryks for his vision and support of this project. At Brill, Arjan van Dijk, Ivo Romein, and Irene Jager worked above and beyond to produce this volume in its best form. A special word of thanks must also be extended to old friends and family whose support, even socially distanced, made this book possible: Brian T. Allen, Nina Edwards Anker, Emma Cherniavsky, D. Perry De Valpine, Yoriko Kobayashi-Sato, Rachel Kousser, Susan Donahue Kuretsky, Fumitaka Matsuoka, Kiichi and Anne Mochizuki, Shinichi Mochizuki, Victoria Pulling, Romita Ray, Aileen Tsui, and Emad Zikry. Lastly, in the spirit of the transportive imagination celebrated in Jesuit art, when so many are sheltering inside and experiencing loss due to illness and isolation, it is hoped that this book might at least offer some small consolation.

(C) MIA M. MOCHIZUKI, 2022 | DOI:10.1163/9789004498228_002

This is an open access chapter distributed under the terms of the CC BY-NC-ND A1 license 
extra-European sites of production. This introduction therefore begins with selections from a spectrum of early modern Jesuit art, not always acknowledged, since art historical investigation emerges from questions posed by the works themselves, before situating them within a thumbnail sketch of their art historical context and major resources for their study. However, the geographic and media expansion of the Society's art-related activities changes not only the objects under analysis; it also affects the kinds of queries that arise. In the pages that follow, readers are forewarned not to expect a monograph on an aspect of Jesuit art, a survey of standard styles and iconographies, or a précis of literature on the topic. Instead, in keeping with the aims of the Brill Research Perspectives series, this volume will assess the signature structural innovations of Jesuit art in the history of the image, a subject that has remained under the radar even in a well-trodden field, to provide a productive framework for further exploration. ${ }^{2}$

As a starting point for a reconsideration of Jesuit art, the monumental retable by Br. Andrea Pozzo (1642-1709) in the Chapel of St. Ignatius of the Church of the Gesù in Rome-St. Ignatius Receiving the Banner with the Monogram of the Name of Jesus from the Resurrected Christ (c.1696-1700) - is about as Jesuit as a work of art can be (figs. 1.1-1.2). ${ }^{3}$ It is an object that depicts St. Ignatius of

2 Robert A. Maryks, ed., Brill Research Perspectives in Jesuit Studies; https://brill.com/view/ serial/RPJSS (accessed March 12, 2021), published as a journal until 2021.

3 For an introduction to the bibliography on the Church of the Gesù, with a focus on the Chapel of St. Ignatius, see Gauvin Alexander Bailey, Between Renaissance and Baroque:Jesuit Art in Rome, 1565-1610 (Toronto: University of Toronto Press, 2003), 187-26o; Richard Bösel, Jesuitenarchitektur in Italien, 1540-1773: 1. Die Baudenkmäler der römischen und der neapolitanischen Ordensprovinz (Vienna:Verlag der Österreichischen Akademie der Wissenschaften, 1985), 160-79; Richard Bösel and Lydia Salviucci Insolera, eds., Mirabili disinganni: Andrea Pozzo (Trento 1642-Vienna 1709); Pittore e architetto Gesuita, exhibition catalog (exh. cat. hereafter) (Rome: Istituto Nazionale per la Grafica, 2010), 136-45; Maurizio Gargano, "L'altare di sant'Ignazio nel Gesù di Roma: Committenza e cantiere," in Andrea Pozzo, ed. Vittorio de Feo and Valentino Martinelli (Milan: Electa, 1996), 156-67; Lydia Salviucci Insolera, "Il dipinto ritrovato dell'altare di S. Ignazio: Nuovi contributi su Andrea Pozzo pittore di pale d'altare a Roma," in Artifizi della metafora: Saggi su Andrea Pozzo, ed. Richard Bösel and Lydia Salviucci Insolera (Rome: Artemide, 2011), 92-115; Evonne Levy, "The Institutional Memory of the Roman Gesù: Plans for Renovation in the 1670 os by Carlo Fontana, Pietro da Cortona, and Luca Berrettini," Römisches Jahrbuch der Bibliotheca Hertziana 33 (1999-200o):373-426; Levy, Propaganda and the Jesuit Baroque (Berkeley: University of California Press, 2004); Roberta Maria dal Mas, "Laltare di sant'Ignazio nel Gesù di Roma: Cronache del progetto," in de Feo and Martinelli, Andrea Pozzo, 144-55; Mia M. Mochizuki, "Jesuit Visual Culture in a Machine

FIGURE 1.1 Andrea Pozzo, St. Ignatius Receiving the Banner with the Monogram of the Name of Jesus from the Resurrected Christ, c.1696-170o, oil on canvas. Rome, Church of the Gesù, Chapel of St. Ignatius 


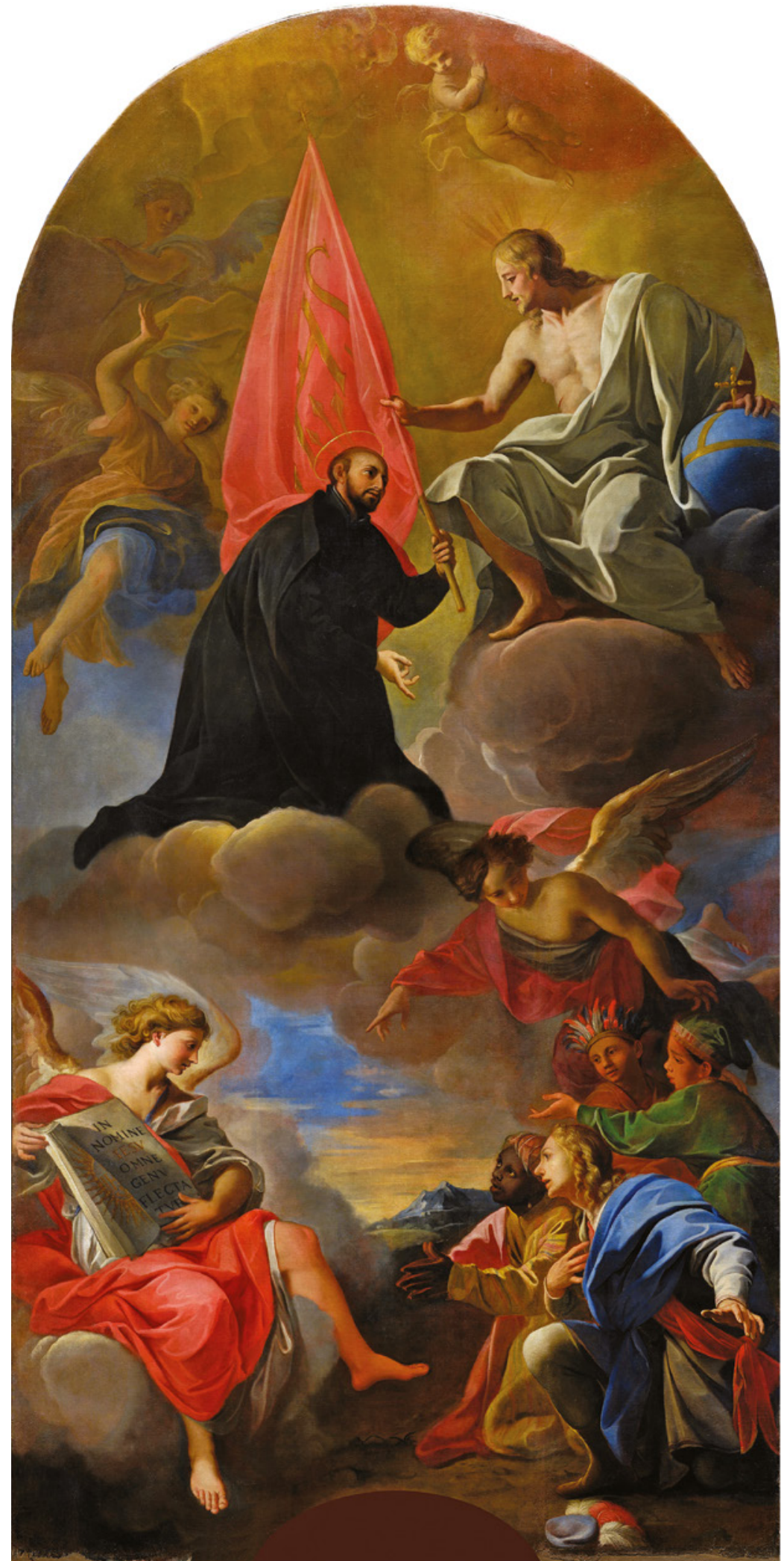

Mia M. Mochizuki - 9789004498228

Downloaded from Brill.com04/26/2023 01:48:39PM 


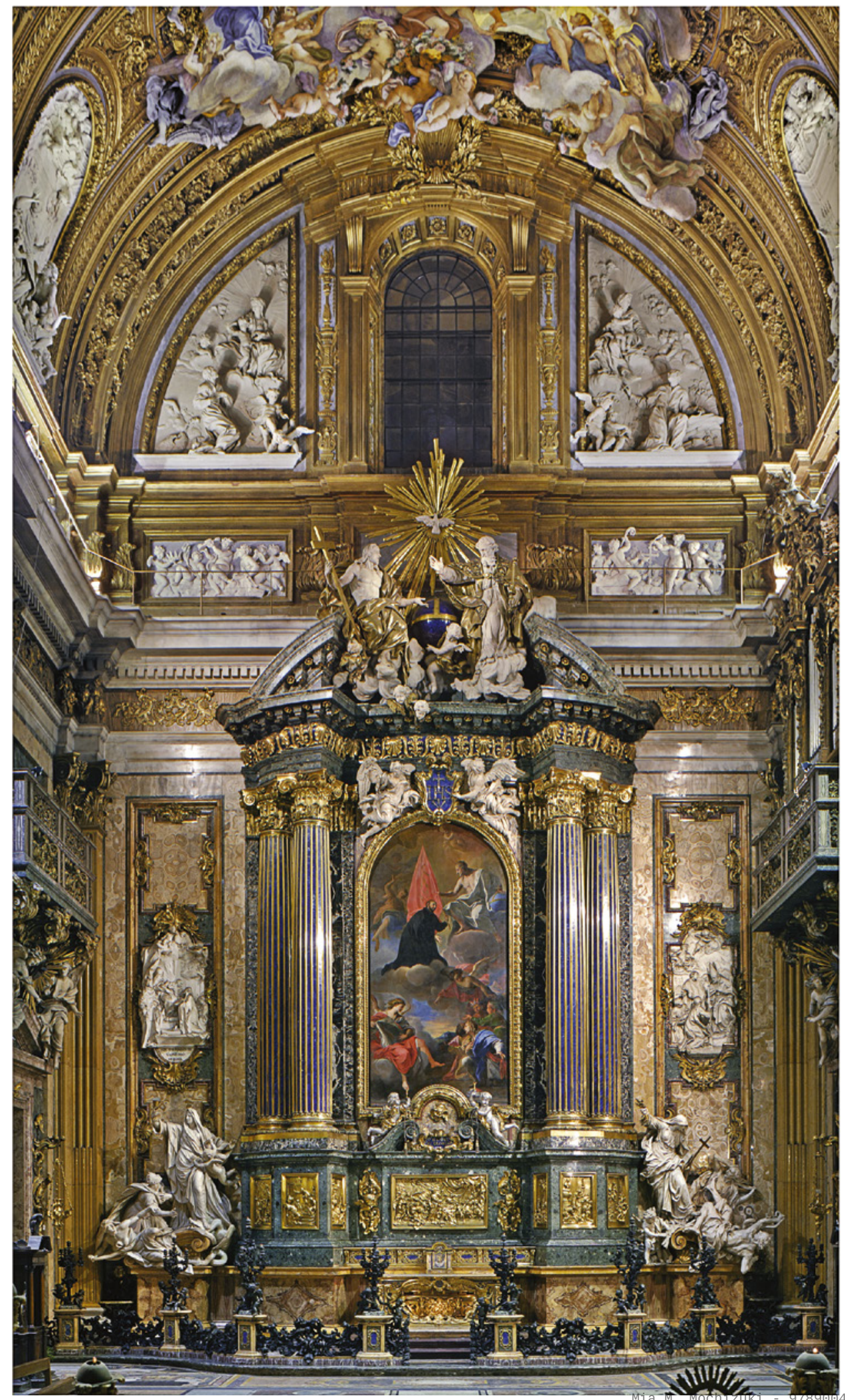


Loyola (c.1491-1556) being tasked by Jesus to form the Society of Jesus, commissioned for the order, painted by a Jesuit artist, in the chapel of the order's founding saint, within its mother church. The painting is presented as part of a wall that proposes a cosmic, inexorable narrative for the coming of the Society to the world initiated by the sculptural grouping of the Trinity (1726) by Lorenzo Ottoni (1658-1736) and Bernardino Ludovisi (1693-1749), the figures conversing over a massive lapis lazuli globe girded across top and middle with bronze bands, the globus cruciger, a sign of God's dominion over the world dating back to the Roman Empire. In the painting, Ignatius receives the banner

Age," in The Oxford Handbook of the Jesuits, ed. Ines G. Županov (Oxford: Oxford University Press, 2019), 449-86, doi: 10.1093/oxfordhb/9780190639631.013.18 (accessed March 13, 2021); Pio Pecchiai, S.J., Il Gesù di Roma (Rome: Società Grafica Romana, 1952), esp. 139-96, 350-61; Pietro Pirri, s.J., Giovanni Tristano e i primordi della architettura gesuitica (Rome: Institutum Historicum Societatis Iesu, 1955), 138-59; Pirri, "La topografia del Gesù di Roma e le vertenze tra Muzio Muti e S. Ignazio," Archivum historicum Societatis Iesu 10 (1941): 177217; Clare Robertson, Il Gran Cardinale: Alessandro Farnese, Patron of the Arts (New Haven: Yale University Press, 1992), 181-96; Robertson, "Two Farnese Cardinals and the Question of Jesuit Taste," in The Jesuits: Cultures, Sciences, and the Arts, 1540-1773, ed. John W. O'Malley, S.J. et al. (Toronto: University of Toronto Press, 1999), 134-47; Giovanni Sale, S.J., Pauperismo architettonico e architettura gesuitica (Rome: Jaca Book, 2001); Sale, "Architectural Simplicity and Jesuit Architecture" and "The Design of the Gesù in Rome: A Difficult Collaboration," in The Jesuits and the Arts, 1540-1773, ed. John W. O'Malley, S.J., and Gauvin Alexander Bailey (Philadelphia: Saint Joseph's University Press, 2005), 27-44, 45-62; Klaus Schwager, "Anlässlich eines unbekannten Stichs des römischen Gesù von Valerianus Regnartius," in Festschrift Lorenz Dittmann, ed. Hans-Caspar von Bothmer et al. (Frankfurt am Main: Peter Lang, 1994), 295-312; Schwager, "Larchitecture religieuse à Rome de Pie IV à Clement VIII," in L'église dans l'architecture de la Renaissance: Actes du colloque tenu à Tours du 28 au ${ }^{1}$ mai 199o, ed. Jean Guillaume (Paris: Picard, 1995), 223-44; Schwager, "La chiesa del Gesù del Vignola," Bollettino del Centro Internazionale di Studi d'Architettura Andrea Palladio 19 (1977): 251-71; Schwager, "Concetto e realtà: Alcune precisazioni sulla difficile nascita del Gesù di Roma," in L'architettura della Compagnia di Gesù in Italia: XVI-XVIII secolo; Atti del convegno Milano, Centro Culturale S. Fedele, 24-27 ottobre 199o, ed. Luciano Patetta and Stefano Della Torre (Genoa: Marietti, 1992), 69-77; Klaus Schwager and Hermann Schlimme, "La chiesa del Gesù di Roma," in Jacopo Barozzi da Vignola, ed. Richard J. Tuttle et al. (Milan: Electa, 2002), 279-99; Rudolf Wittkower and Irma B. Jaffe, eds., Baroque Art: The Jesuit Contribution (New York: Fordham University Press, 1972); Linda Wolk-Simon, ed., The Holy Name: Art of the Gesù; Bernini and His Age, Early Modern Catholicism and the Visual Arts 17, exh. cat. (Philadelphia: St. Joseph's University Press, 2018). For an explanation of terms that frequently appear in early modern Jesuit archival research, like the temporal coadjutor (coadiutor temporalis), the lay religious brothers who assisted professed members, see Wiktor Gramatowski, s.J., Jesuit Glossary: Guide to Understanding the Documents, trans. Camilla Russell, rev. ed. (Rome: Archivum Romanum Societatis Iesu, 2013); http://www.sjweb.info/arsi/documents/glossary. pdf (accessed March 13, 2021). 
with the monogram of the Society from Jesus, who rests his left hand on a cerulean blue globus cruciger. Underneath, an angel holds a book open to the words "In nomine Iesu, omne genu flectatur" - a reference to Philippians 2:10: "So that at the name of Jesus / every knee should bend, / in heaven and on earth and under the earth" - and the allegorical figures of the four continents kneel in response to the name of Jesus. ${ }^{4}$ The causal connection between the Society and the world is then made explicit in the sculptural groupings to either side of the altar: the founding of the order by St. Ignatius above has culminated in the triumph of the church over universal heterodoxy below, sending Pierre Le Gros the Younger's (1666-1719) Religion Defeating Heresy (1695-99) on the right and Jean-Baptiste Théodon's (1645-1713) Faith Defeating Idolatry (1695-99) on the left, complete with the converted king of the Congo, scuttling to the corners. All manner of heretics and idols are trampled: Faith's foot crushes a book entitled "Cames fotoque amida et xaca," the Latinized version of the Portuguese names for Japanese and Chinese gods, and Religion and her putto tear out the pages of books authored by "Luther," "Calvin," and "Zwingli." In a Jesuit artist's vision, the creation of the Society was positioned at the juncture where the Reformation met the world, an appropriate characterization for the variety of objects spanning media, techniques, and cultures that would become integral parts of the heritage of Jesuit art.

One of the prime distinguishing features of Jesuit art was the launch of artistic workshops around the globe, in the process setting up the first system of worldwide production for art. At the farthest point from Europe, a studio under the leadership of Br. Giovanni Niccolò (or Giovanni Cola, 156o-1626), who trained in the atelier of Giovanni Bernardo Lama (1508-79) in Naples before entering the order, was founded in Japan in $1583 .{ }^{5}$ At the highpoint of

4 Biblical translation in this volume follows the New Revised Standard Version (NRSV).

5 The Niccolò School was not fully active until about 1590, when it moved around Japan at least eleven times, before being forced to decamp to Macau in 1614. Eleven names have been connected with the Niccolò School: some were Jesuits, complete or in formation, and others were not necessarily Jesuit-affiliated Japanese. Gauvin Alexander Bailey, Art on the Jesuit Missions in Asia and Latin America, 1543-1773 (Toronto: University of Toronto Press, 1999), 53, 71-72; Yoshie Kojima, "Reproduction of the Image of Madonna Salus Populi Romani in Japan," in Between East and West: Reproductions in Art, ed. Shigetoshi Osano and Milosz Wozny, Proceedings of the 2013 CгнA Colloquium in Naruto, Japan, Tokyo, January 15-18, 2013 (Krakow: Institute for Art Historical Research/IRSA, 2014), 373-87, here 382; Georg Schurhammer, s.J., "Die Jesuitenmissionare des 16. und 17. Jahrhunderts und ihr Einfluss auf die japanische Malerei," Gesammelte Studien, ed. László Szilas, S.J. (Rome: Institutum Historicum Societatis Iesu, 1963-65), 2:769-79, here 773-74. For a list of Jesuit residences, novitiates, colleges, language schools, seminaries, and painting and publishing establishments in early modern Japan, including founders' names, compiled by the Twenty-Six 
the Niccolò School's almost quarter-century of existence, it was responsible for much of the art and books in all the Society's missions from Goa eastward. It was never an autonomous academy; an artistic training was part of the Jesuit education of the whole person, or cura personalis, which involved painting, printmaking, and the manufacture of clocks and musical instruments (organ, viola d'arco, harp, lute, viola semplice, and harpsichord), alongside theology, Latin, music, theater, and literature, as chronicled by Luís Frois (1532-97) in a letter from Nagasaki (December 13, 1596). ${ }^{6}$ Niccolò School artists painted the Madonna and Child with the Fifteen Mysteries of the Rosary and Saints Ignatius, Francis Xavier, Matthias, and Lucy (c.1590-1614) in the Kyoto University Art Museum, whose double-decker scaffolding features the Madonna and Christ Child, Jesus holding the globus cruciger in benediction, with Saints Ignatius and Francis Xavier $\left(1_{506-52)}\right.$ in prayer before the host and chalice centered above the monogram of the Society (fig. 1.3). ${ }^{7}$ Scenes of the fifteen mysteries of the rosary ring the perimeter- the five joys of the incarnation of Christ on the left side, the five sorrows of the passion and death of Christ across the top, and the five glories of the resurrection and reign of Christ in heaven with Mary on the right side- to present a pictorial compendium of the life of Christ derived from the Gospel of St. Luke. ${ }^{8}$ This is a picture of Jesuits praising the sacrament of the Eucharist, designed by a Jesuit workshop, to spark catechesis and devotion on a Jesuit mission, art in many ways as central to the Jesuit enterprise

Martyrs Museum (Renzo De Luca, s.J.), see http://www.26martyrs.com (accessed March 13, 2021).

6 Luís Frois, Lettera annua del Giappone dell'anno 1596 (Rome: Luigi Zanetti, 1599), 78-79; Frois, Lettera del Giappone degli anni 1591 et 1592 (Rome: Luigi Zanetti, 1595), 165; Pedro Gómez, Lettera annua del Giappone dal marzo del 1593 fino al marzo del 1594 (Rome: Luigi Zanetti, 1597), 68-69; M. Antoni J. Üçerler, S.J., "Alessandro Valignano and Jesuit Humanist Education in Japan," in St. Francis Xavier: An Apostle of the East, ed. Executive Committee 45oth Anniversary of the Arrival of St. Francis Xavier in Japan (Tokyo: Sophia University Press, 1999-2000), 2:74-84.

7 St. Matthias (February 24, since moved to May 14), the disciple chosen to replace Judas Iscariot (not to be confused with St. Matthew the Evangelist), is shown with an axe, a reference to the method by which he was killed after miraculously surviving stoning as a punishment for preaching in Judea. St. Lucy's (December 13) first set of gouged-out eyes, the symbol of her torture, are presented on a golden platter. James Bridge, "St. Lucy," in The Catholic Encyclopedia, ed. Charles G. Herbermann et al. (New York: Robert Appleton Co., 1907-14), 9:414-15; Jacque Eugène Jacquier, "St. Matthias," in Herbermann, Catholic Encyclopedia, 10:66; Alban Butler, Butler's Lives of the Saints, ed. Herbert J. Thurston, s.J., and Donald Attwater, rev. ed. (Allen, TX: Christian Classics, 1996), 2:407-8; 4:548-49.

8 The five joyful mysteries of the rosary are: the Annunciation of Gabriel to the Virgin Mary (Lk 1:26-38), the Visitation of the Virgin Mary to Elizabeth (Lk 1:39-56), the Nativity (Lk 2:121), the Presentation of Christ in the Temple at Jerusalem (Lk 2:22-38), and the Finding of 


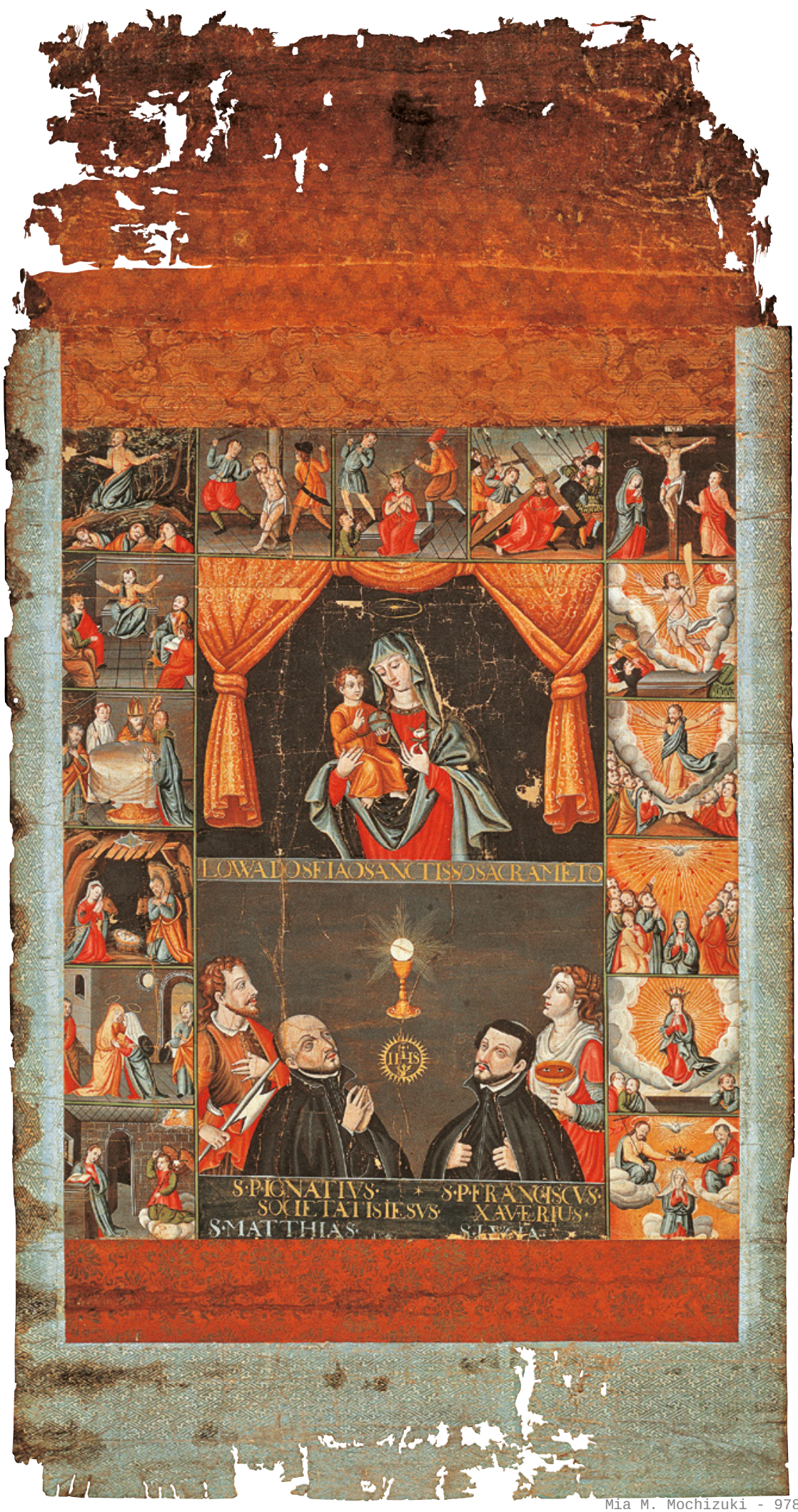


as the Gesù. And from an art historical standpoint, the Niccolò workshop was the first place where western subject matter and compositions, as well as techniques of oil painting and copper engraving, were introduced to Japanese audiences. $^{9}$

But Jesuit art was not restricted to Jesuit artists and workshops. Leading figures, such as Peter Paul Rubens (1577-1640) and Gian Lorenzo Bernini (1598-1680), enjoyed long-standing ties with the Society and executed masterpieces for Jesuit patrons. The result was paintings like the magnificent pendant portraits of the Miracles of St. Ignatius of Loyola and St. Francis Xavier (c.1617-18), made for the Jesuit Church of St. Charles Borromeo in Antwerp (figs. 1.4-1.5). ${ }^{10}$ The pair represented the founder and chief missionary of the Society as active, can-do saints, larger than life miracle-workers whose deeds moved beyond the expression of faith in the ceiling paintings to promise societal renewal in real time. The subject matter, location, and patronage of these paintings situates them among the foremost examples of Jesuit art. In addition to intramural artistic activity, the early Society of Jesus endorsed a patronage

Jesus in the Temple at Jerusalem ( $\left.\operatorname{Lk} 2: 41-5^{2}\right)$. The five sorrowful mysteries of the rosary are: the Agony of Our Lord in the Garden of Gethsemane (Mt 26:36-56), Christ Scourged at the Pillar (Mt 27:26), Christ Crowned with Thorns (Mt 27:27-31), Christ Carrying the Cross to Calvary (Mt 27:32), and the Crucifixion of Our Lord (Mt 27:33-56). The five glorious mysteries of the rosary are: the Resurrection of Our Lord (Jn 20:1-29), the Ascension of Our Lord into Heaven (Lk 24:36-53), the Descent of the Holy Spirit to the Virgin Mary and the Apostles at Pentecost (Acts 2:1-41), the Assumption of the Virgin Mary into Heaven (Munificentissiums Deus, Pope Pius XII 1950), and the Coronation of Mary as the Queen of Heaven and Earth (Rv 12:1). In 2002, Pope St. John Paul II (1920-2005, r.1978-2005) added a set of five luminous mysteries of the rosary: the Baptism of Our Lord in the River Jordan (Mt 3:13-16), the Wedding Feast at Cana (Jn 2:1-11), the Proclamation of the Kingdom of Heaven (Mk 1:4-15), the Transfiguration of Our Lord (Mt 17:1-8), and the Institution of the Eucharist at the Last Supper (Mt 26).

9 Yoriko Kobayashi-Sato and Mia M. Mochizuki, Gurōbaru jidai no yoake: Nichiō bunka no deai, kosaku to sono zanshō 1541-1853 (Kyoto: Koyo Shobo, 2017).

10 After the suppression, the paintings were acquired by Holy Roman Emperor Josef II (1741-9o, r.1765-9o) for the imperial collection in Vienna in 1776 , eventually becoming part of the Kunsthistorisches Museum. For an introduction to the extensive bibliography on these paintings, see Christine Göttler, 'Actio' in Peter Paul Rubens' Hochaltarbildern für die Jesuitenkirche in Antwerpen," in Barocke Inszenierung: Akten des Internationalen Forschungscolloquiums an der Technischen Universität Berlin 20.-22. June 1996, ed. Joseph Imorde, Fritz Neumeyer, and Tristan Weddigen (Emsdetten: Edition Imorde, 1999), 10-31, esp. 11, 14 .

$\leftarrow \quad$ FIGURE 1.3 Niccolò School, Madonna and Child with the Fifteen Mysteries of the Rosary and Saints Ignatius, Francis Xavier, Matthias, and Lucy, c.159o-1614, oil, Japanese colors, and ink (sumi) on bamboo paper. Kyoto, Kyoto University Museum

PHOTO: (C) KYOTO UNIVERSITY MUSEUM 


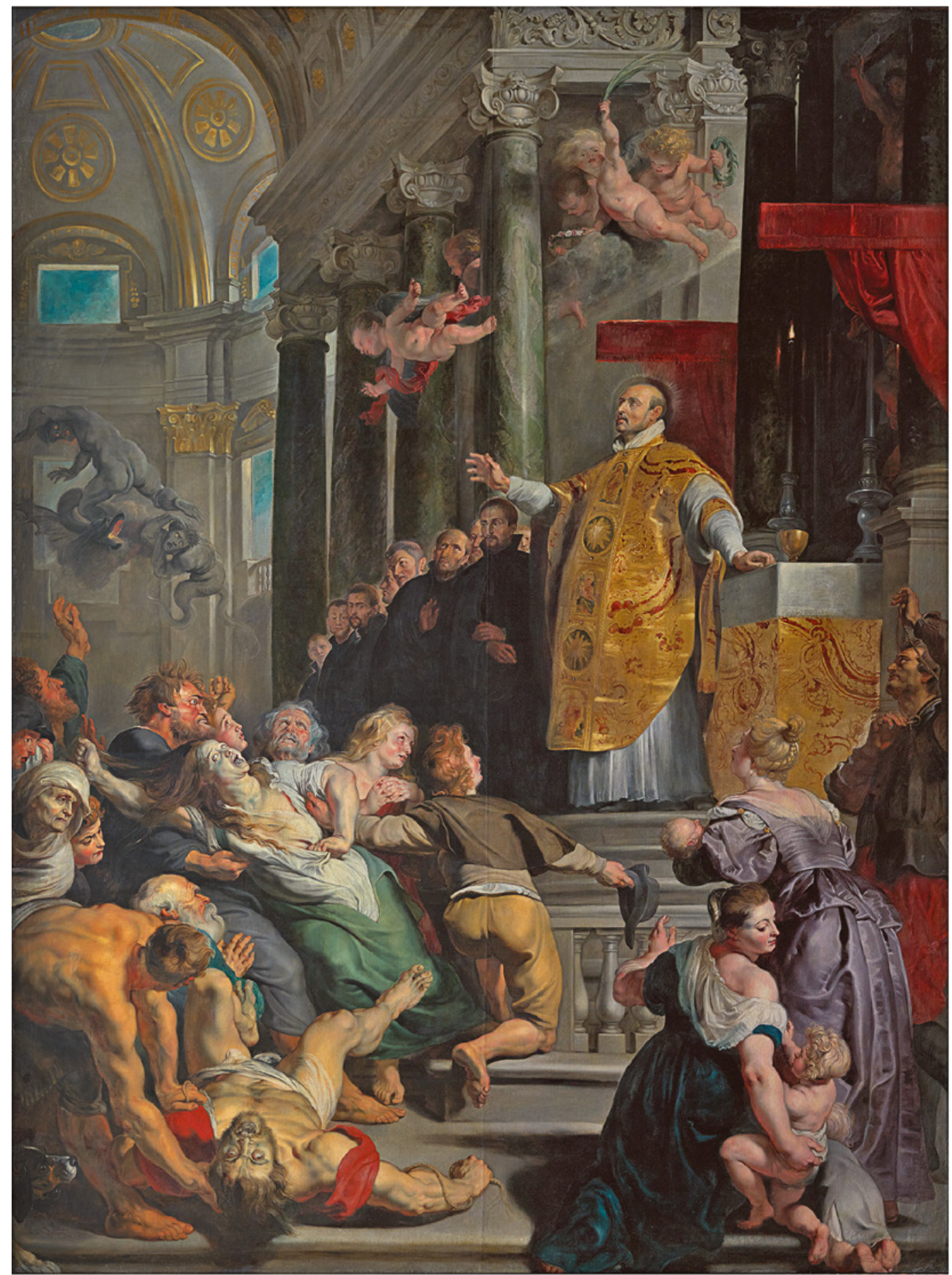

FIgURE 1.4 Peter Paul Rubens, The Miracles of St. Ignatius of Loyola, c.1617-18, oil on canvas (inv. no. GG 517). Vienna, Kunsthistorisches Museum PHOTO: (C) KHM-MUSEUMSVERBAND 


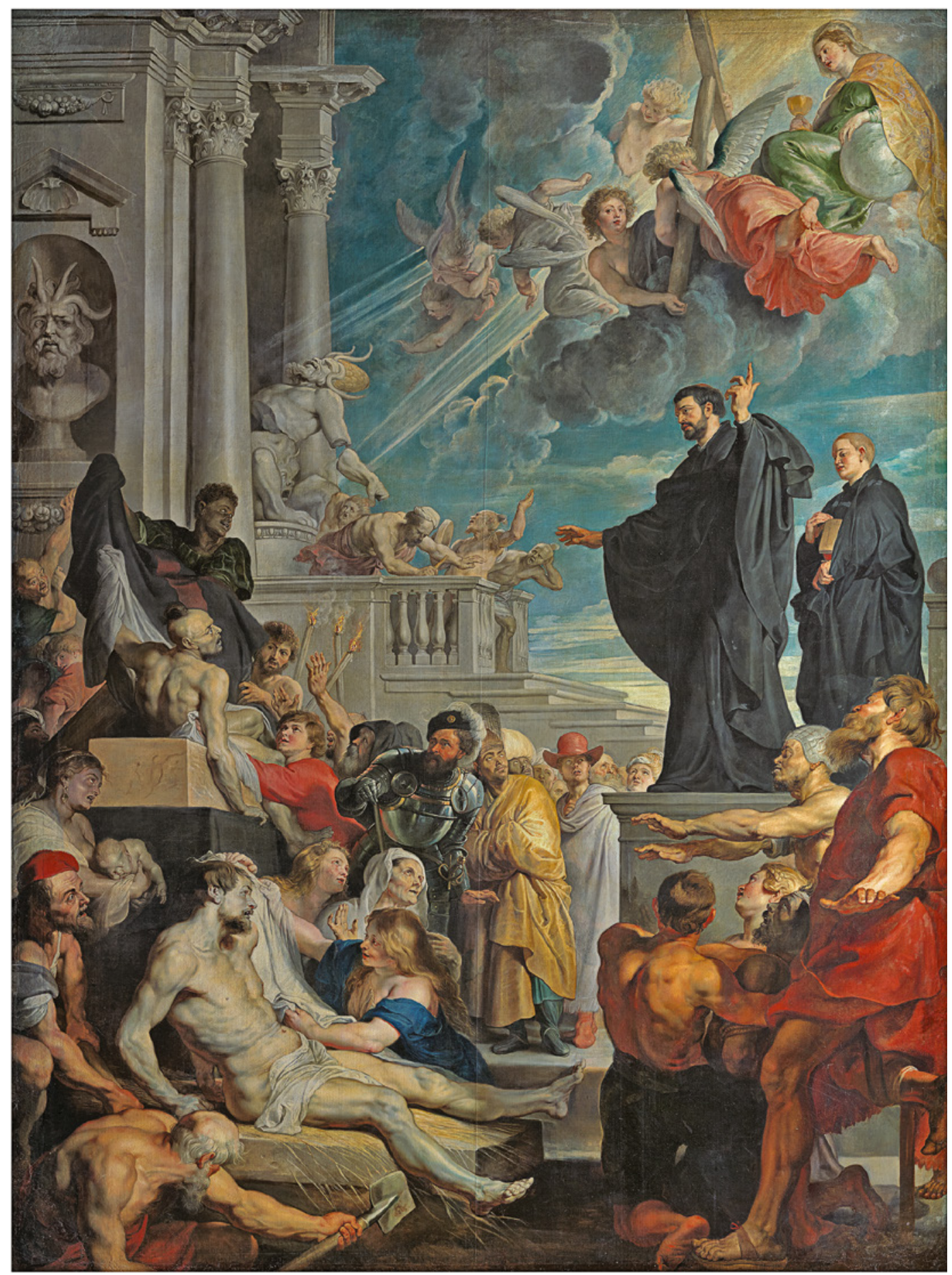

FI GURE 1.5 Peter Paul Rubens, The Miracles of St. Francis Xavier, c.1617-18, oil on canvas (inv. no. Gg 519). Vienna, Kunsthistorisches Museum PHOTO: (C) KHM-MUSEUMSVERBAND 
of the arts that was as distinguished by the quality of its imagery as it was by its quantity, as seen in the publishing houses of Antwerp, where the Society maintained close commercial and personal ties with individual presses, like the Plantin-Moretus Press, and artistic dynasties involved in the industry, such as the Wierix family, whose designs and engravings decorated numerous Jesuit books." ${ }^{11}$ A nephew of the publisher Jan I Moretus (1543-1610), a son of Pieter Moretus (or Moerentorf, 1544-1616) and Henrica (or Henriette) Plantin (c.15611640) named Theodor Moretus (16o2-67), would become an esteemed Jesuit mathematician, physicist, and author of a book in defense of the immaculate conception, Principatus incomparabilis primi filii hominis, Messiae, et primae parentis Matris Virginis in conceptione illius immaculata exhibitus (Exhibited empire of the incomparable, most excellent Son of Man, the Messiah, and of the noble parent, the Virgin Mother, immaculate in the conception of that [Son] [Cologne: Johann Busäus, 1671]). ${ }^{12}$ Jesuit-commissioned art shows that the roots of the Society in society-at-large ran deep, intricately interwoven around collaborative projects and mutual interests.

Aside from the art that was initiated by Jesuits, a body of work exists surrounding objects closely identified with Jesuit devotion, such as the highly venerated Salus Populi Romani Madonna, the "Protectress of the Roman People," housed in the Basilica of Santa Maria Maggiore in Rome, an Italo-Byzantine icon reputed to have been painted by St. Luke on a tabletop built by the young Jesus between the sixth and tenth centuries. ${ }^{13}$ On the morning after the election of the first Jesuit pope (March 14, 2013), Pope Francis I (r.2013-) paid an unannounced visit to the Salus Populi Romani Madonna to ask for the

11 Paul Begheyn, S.J., "Jesuits in the Low Countries and Their Publications," in Jesuit Books in the Low Countries, 1540-1773: A Selection from the Maurits Sabbe Library, ed. Paul Begheyn, s.J. et al. (Leuven: Peeters, 2009), xxi-xxv, here xxiii; Maurits Sabbe, De Meesters van de Gulden Passer: Christoffel Plantin, Aartsdrukker van Philips II, en zijn opvolgers, de Moretussen (Rotterdam: Ad. Donker, 1978), 107-11; Adrianus de Wilt, s.J., "Enkele leden van de familie Plantin en de Annuntiaten," De Gulden Passer 38 (1960): 140-5o.

12 Frans Baudouin, "Balthasar I Moretus, 'Gheestelyck Vader,' en zijn verwanten, begunstigers van de Antwerpse Annuntiaten," in Ex officina Plantiniana Moretorum: Studies over het drukkergeslacht Moretus, ed. Marcus De Schepper and Francine de Nave, De Gulden Passer, Special Issue, 74 (1996): 131-56; Henri Bosmans, S.J., "Théodore Moretus de la Compagnie de Jésus, mathématicien (1602-1667): D’après sa correspondance et ses manuscrits," De Gulden Passer 6 (1928): 57-162; Hermann Hoffmann, "Der Breslauer Mathematiker Theodor Moretus S.J. (1601-1667)," Schlesische Gesellschaft für Vaterländische Cultur 107 (1934): 118-55.

13 Hans Belting, Likeness and Presence: A History of the Image before the Era of Art, trans. Edmund Jephcott (Chicago: University of Chicago Press, 1994), 68-72; Gerhard Wolf, Salus Populi Romani: Die Geschichte römischer Kultbilder im Mittelalter (Weinheim: VCH, Acta Humaniora, 1990), 24-28. 
intercession of the Blessed Virgin Mary for his pontificate; a photograph captures another moment of prayer with the icon before his apostolic visit to Brazil for World Youth Day later the same year (July 20, 2013) (fig. 1.6). His devotion to this picture reflected a long-standing Jesuit veneration of this image. Already on November 5, 1566, the spiritual diary of St. Francisco de Borja (1510-71), third superior general of the Society of Jesus (in office 1565-72), reads: "Day of dedication etc. Consolation before an image of the Madonna," suggesting that Borja visited the Salus Populi Romani Madonna on his return from the Basilica of St. John the Lateran. ${ }^{14}$ The fifth superior general, Claudio Acquaviva (15431615, in office 1581-1615), made a pilgrimage every Saturday to see the painting. Cardinal Francisco de Toledo (1532-96, in office 1593-96), the first Jesuit cardinal, also went to Santa Maria Maggiore weekly to celebrate Mass, and when he passed away on September 14, 1596, he left an annual benefice to ensure its continuation, with two candles to be lit before the icon every twelve days. ${ }^{15}$ By the seventeenth century, the Salus Populi Romani Madonna was ranked second only to the wonder-working image of Loreto, out of the twelve hundred miraculous Marian images cited in the definitive edition of Wilhelm Gumppenberg's (16o9-75) Atlas Marianus (Marian atlas [Munich: Johann Jaecklin, 1672]), leaving no doubt that images to which Jesuits nurtured a special devotion were also integral to the cultural imagination of the early modern Society of Jesus. ${ }^{16}$

Jesuits, however, were not only great creators and profound appreciators of art; they were also the prodigious mediators of the time, and it was through their transportation of objects across the high seas that western art spread farther than ever before. Like Helen of Troy, the Salus Populi Romani Madonna was the "face that would launch a thousand ships," and its fame in

14 Juan de Borja y Enríquez, Sanctus Franciscus Borgia, quartus Gandiae dux et Societatis Jesu praepositus generalis tertius (Monumenta Borgia), ed. Cecilio Gómez Rodeles, S.J. (Madrid: Typis Augustinus Avrial and Gabrielis Lopez del Horno, 1894-1911), 5:839; Pasquale M. d'Elia, s.J., "La prima diffusione nel mondo dell'immagine di Maria 'Salus Populi Romani,"” Fede e arte 2 (October 1954): 301-11, here 302, 310, n. 7; Rafael García Mahíques, "Francisco de Borja y la visualidad jesuítica," in Francisco de Borja y su tiempo: Política, religión y cultura en la edad moderna, ed. Enrique García Hernán and María del Pilar Ryan (Valencia: Albatros Ediciones, 2011), 577-95; Pierre Suau, s.J., Histoire de Saint François de Borgia, troisième général de la Compagnie de Jésus (1510-1572) (Paris: Gabriel Beauchesne \& Cie, 1910), 414, 572, n. 4.

15 D'Elia, "Prima diffusione nel mondo dell'immagine di Maria 'Salus Populi Romani," 302, 310, n. 9; Egidio Marcolini, S.J., Mater Divinae Gratiae: La Madonna del noviziato nella provincia Veneto-Milanese della Compagnia di Gesù (Padua: Tipografia Antoniana, 1941), 22.

16 Olivier Christin, Fabrice Flückiger, and Naüma Ghermani, eds., Marie mondialisée: L'Atlas Marianus de Wilhelm Gumppenberg et les topographies sacrées de l'époque moderne (Neuchâtel: Éditions Alphil-Presses Universitaires Suisses, 2014). 


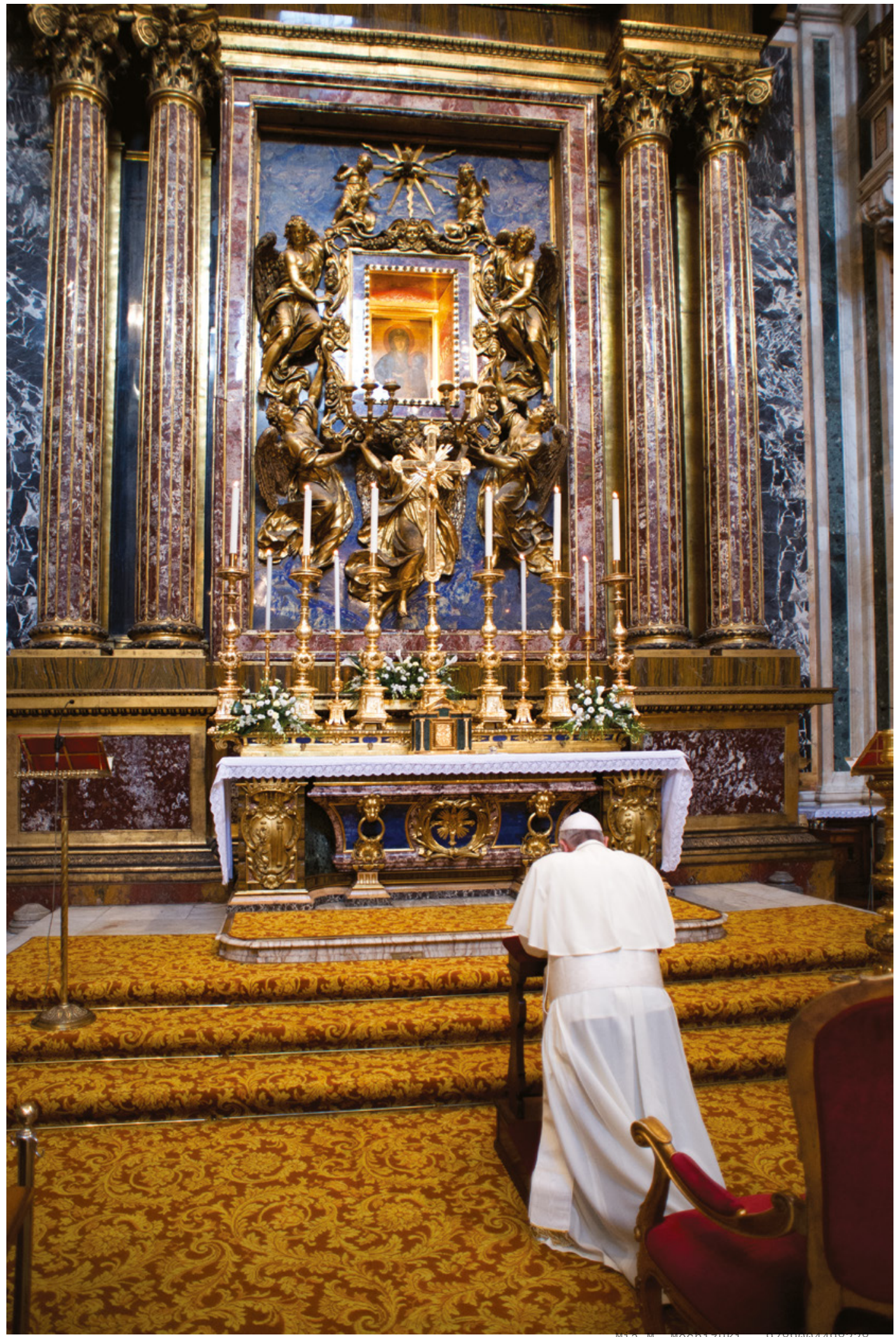


the theatrum mundi (theater of the world) was due to the logistics of Jesuits moving from town to town and region to region until they had crisscrossed the globe. ${ }^{17}$ An anonymous Portuguese artist's Portrait of Blessed Inácio de Azevedo with the Salus Populi Romani Madonna from the turn of the seventeenth century testifies to what can already be adduced from the many objects whose subject matter, compositional quotations, and occasional techniques can be found in partially local vernaculars (fig. 1.7).18 In this image, Blessed Inácio de Azevedo (1526-70), appointed provincial of Brazil by Borja in 1569, only to meet an untimely end soon after as one of the "Forty Martyrs of Brazil" when Calvinist sympathizers captured his convoy, displays a copy of the Salus Populi Romani Madonna, at just under body-size, enlarged to a multiple of the original before the sidelined human figure. ${ }^{19}$ The unusual scale of its depiction speaks to the empowerment of this image-within-an-image in a compositional hierarchy ranked by pictorial mobility: the progression into depth moves from the "Virgin Azevediana," so valuable that the provincial supposedly held on to it as he went overboard; to the caped stagehand of a Jesuit cultural mediator; and lastly, the vehicle of connection, an ocean-worthy Portuguese caravel. ${ }^{20}$

17 "Was this the face that launch'd a thousand ships / And burnt the topless towers of Ilium? / Sweet Helen, make me immortal with a kiss." Christopher Marlowe, "The Tragical History of the Life and Death of Doctor Faustus," c.1592, act 5, scene 1. Christopher Marlowe, Doctor Faustus and Other Plays, ed. David Bevington and Eric Rasmussen (Oxford: Oxford University Press, 1995), 178, 238.

18 Mia M. Mochizuki, "Fukusei gijutsu jidai ni okeru shūkyōga: Sekai no 'Sarusu Popuri Romani Seibozō' wo megutte," in Kirishitan ga hiraita Nihongo bungaku: Tagengo tabunka kouryū no engen, ed. Nanyan Guo (Tokyo: Akashi Shoten, 2017), 273-97; Mochizuki, "Sacred Art in an Age of Mechanical Reproduction: The Salus Populi Romani Madonna in the World," in Sacred and Profane in Early Modern Art, ed. Kayo Hirakawa, Kyoto Studies in Art History 1 (Kyoto: Kyoto University, 2016), 129-44.

19 On June 5, 1570, the largest expedition of Jesuits sent from the Portuguese Empire to date departed from Lisbon for Brazil under Inácio de Azevedo, who had recruited seventythree men to join him. On July 15, 1570, the Santiago was attacked by French Huguenots off the coast of San Miguel de La Palma, the Canary Islands, Spain, casting Azevedo and thirty-nine of his companions into the sea. A second ship survived the first attack only to fall victim to French corsairs on September 13, 1570. Dauril Alden, The Making of an Enterprise: The Society of Jesus in Portugal, Its Empire, and Beyond, 1540-1750 (Palo Alto: Stanford University Press, 1996), 74-75.

20 Two copies of the Salus Populi Romani Madonna were given to Azevedo by Borja, one of which was in his hand at the moment of his death. D'Elia, "Prima diffusione nel mondo dell'immagine di Maria 'Salus Populi Romani," 302; Fausto Sanches Martins, "Notícia sobre o autor e a data do quadro da 'Virgem S. Lucas' do Colégio de Coimbra," Lusitana sacra, 2nd series, 5 (1993): 121-35, here 122.

FIgURE 1.6 Pope Francis I in prayer before the Salus Populi Romani Madonna, July 2o, 2013. Rome, Basilica of Santa Maria Maggiore, Pauline Chapel PHOTO: (C) SERVIZIO FOTOGRAFICO VATICANO 


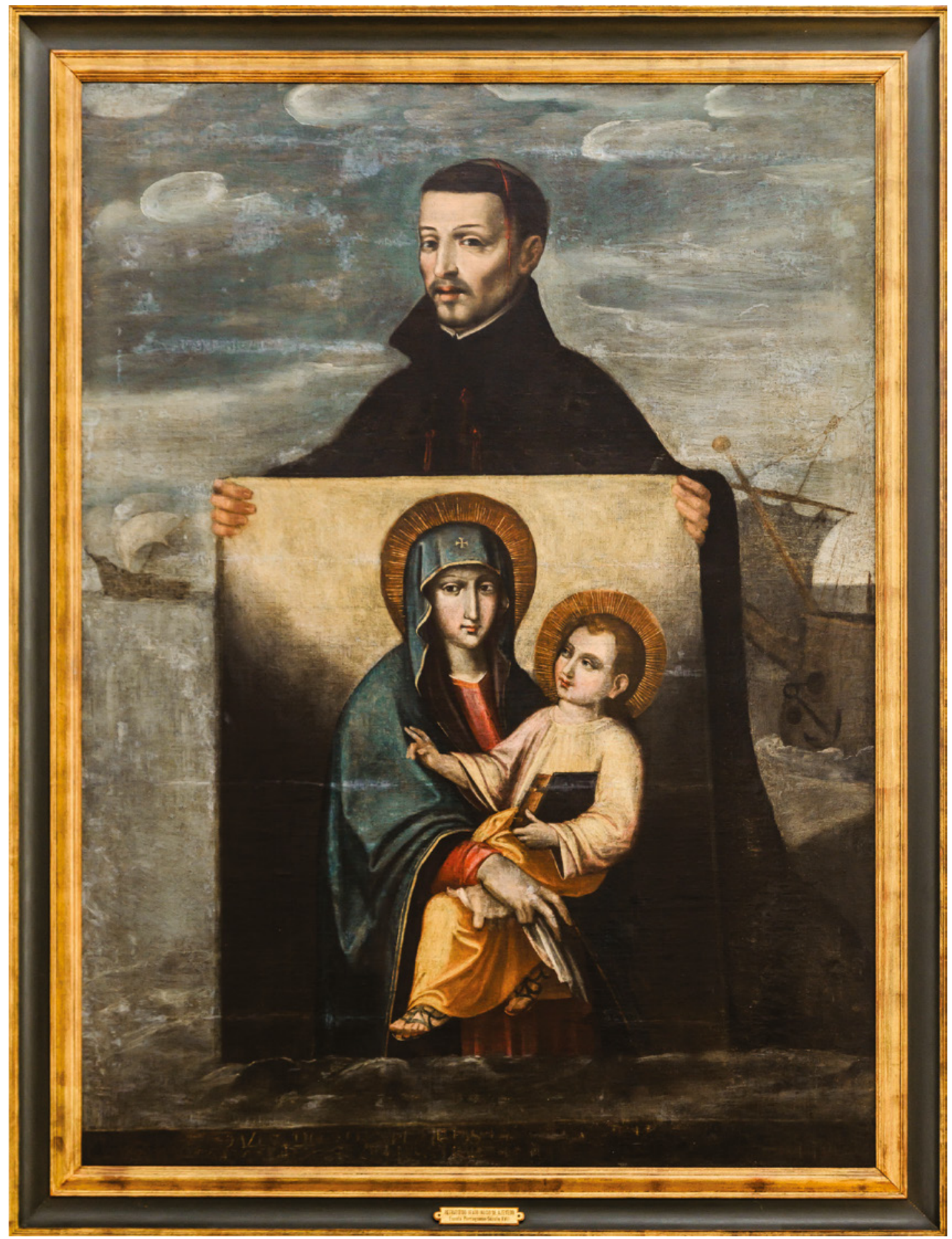

FIgURE 1.7 Portuguese School, Portrait of Blessed Inácio de Azevedo with the Salus Populi Romani Madonna, late sixteenth century-early seventeenth century, oil on canvas. Lisbon, Private Collection

PHOTO: INÊS CORREIA DE MATOS 
Together, this unlikely trifecta of icon with its human and mechanical means of conveyance triangulates one of the most consequential problems sixteenthcentury exploration has posed for art history: how the global circulation of objects affected the way art shaped ideas.

Outside Europe, Jesuits were objects of curiosity, and images from many cultures signal an interest in the Jesuit missionaries who began to appear in their countries. So Jesuit-related art could reasonably comprise not only those objects yielded from trans-cultural contact prompted by Jesuits, but also images of Jesuits in non-European art, what is generally referred to as the distinction between "global" and "world" art in the art historical lexicon. For example, an exceptional pair of screens by Kanō Naizen (1570-1616), Departure of a Ship from a Western Port and Arrival of a Ship in a Japanese Port, late sixteenth to early seventeenth century, document the appearance of black-cloaked and biretta-topped Jesuits in Japan (fig. 1.8). They appear on the left screen among the crowds gathered for the departure of the ship from a Christian port city, one complete with a chapel whose altar features a Salvator mundi (Savior of the world), and disconcertingly, a monstrance with host on the rooftop of another building, and on the right screen, interspersed throughout the landscape of a Japanese coastal town, like Nagasaki, where the ship docks. In just one vertical excerpt from the right screen, from top to bottom, a Jesuit, joined by two companions, responds to a request, with other Japanese and Jesuit figures in attendance (fig. 1.9). Golden clouds part to expose a Mass for Japanese converts before another Salvator mundi altarpiece, the host raised by the celebrant now portrayed with the heft of a gold ball, as if to stress its import. Jesuits go about their daily business, engaged with a cross-section of local society: Japanese men and women, Portuguese merchants in their signature bombasha balloon-shaped pantaloons, and the distinctive gray hooded habit of Franciscan friars. A shopkeeper pokes her head outside and beckons the group to come into her shop filled with curios, from exotic animals, like tigers and peacocks, to bolts of fabric, rare ceramic-ware, and small sculptures, a snapshot of objects linked to the arrival of western "black ships" (kurofune) in Japan. Representations of Jesuits disclose how others saw them, and the primary evidence of the responses they engendered is as critical to understanding the order as the Society's stated intentions.

Pictures with Jesuit protagonists could also assume a decidedly negative slant, conspicuously in areas hostile to Catholicism and/or Jesuit engagement with local politics, with the various strands of anti-Jesuit polemic adopting increasingly antagonistic positions in the lead up to the suppression of the 

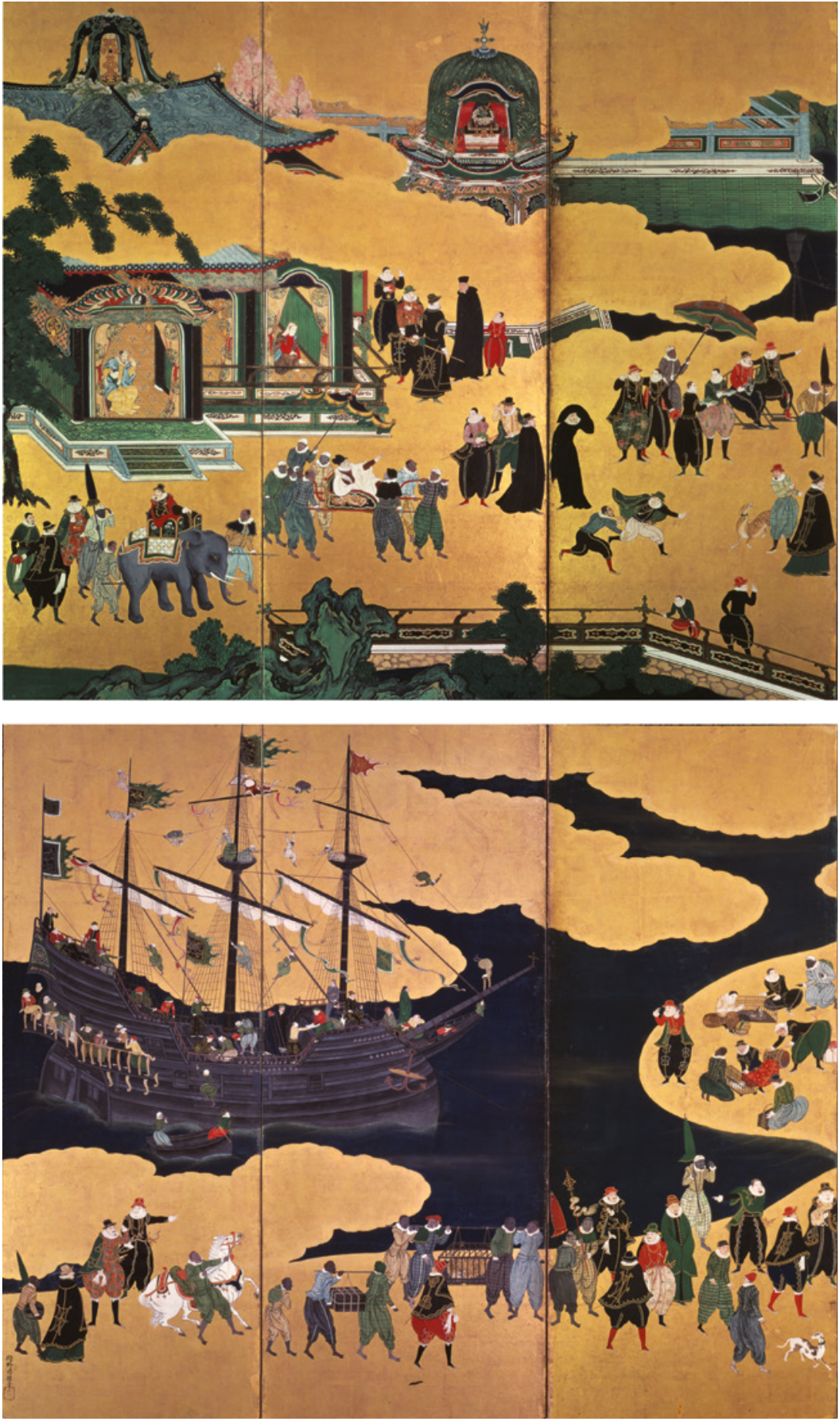

FIg URE 1.8 Kanō Naizen, Departure of a Ship from a Western Port and Arrival of a Ship in a Japanese Port, late sixteenth-early seventeenth century, pair of six-part screens, Japanese colors and gold leaf on paper. Kobe, Kobe City Museum PHоTо: (C) KOBE CITY MUSEUM Mia M. Mochizuki - 9789004498228 

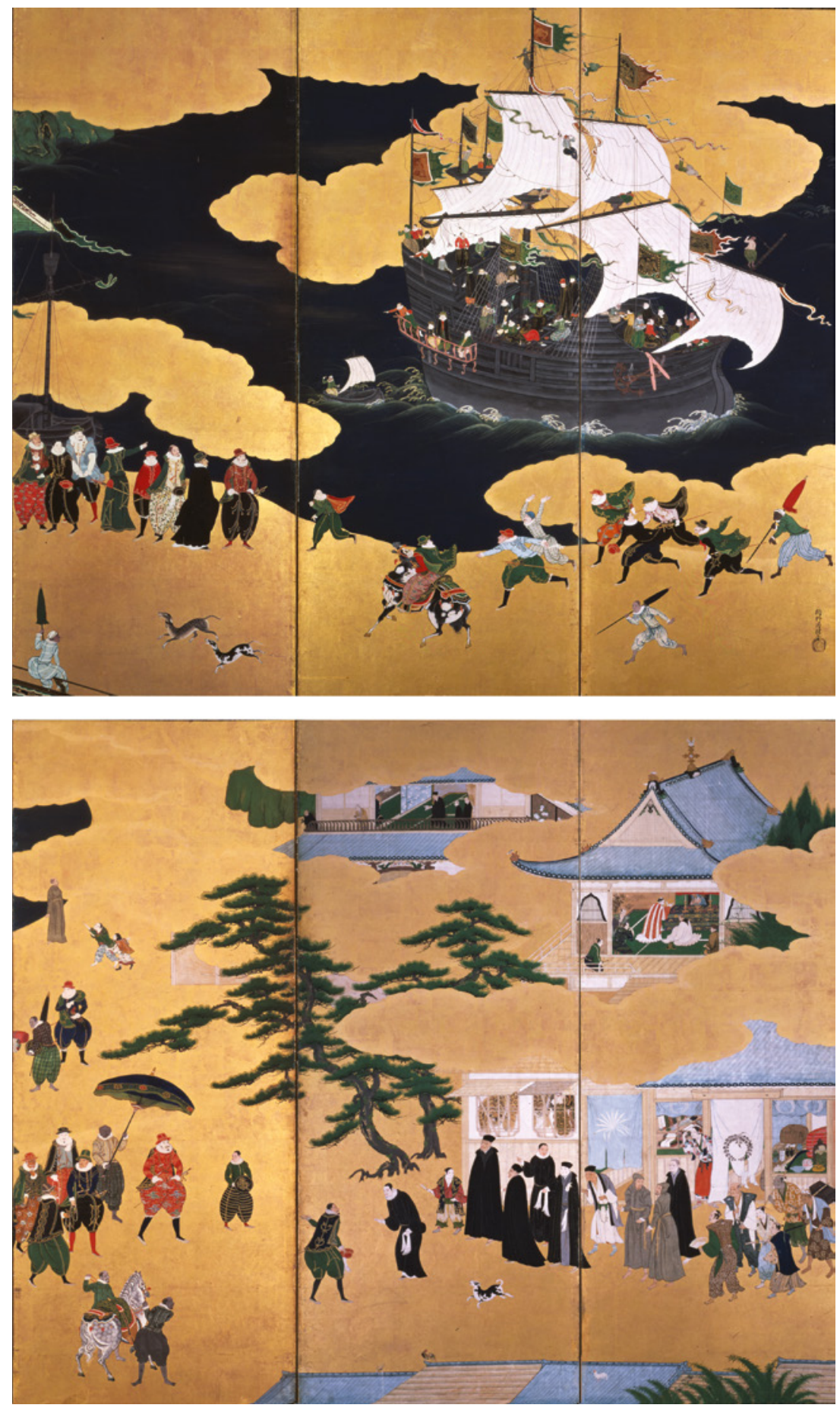


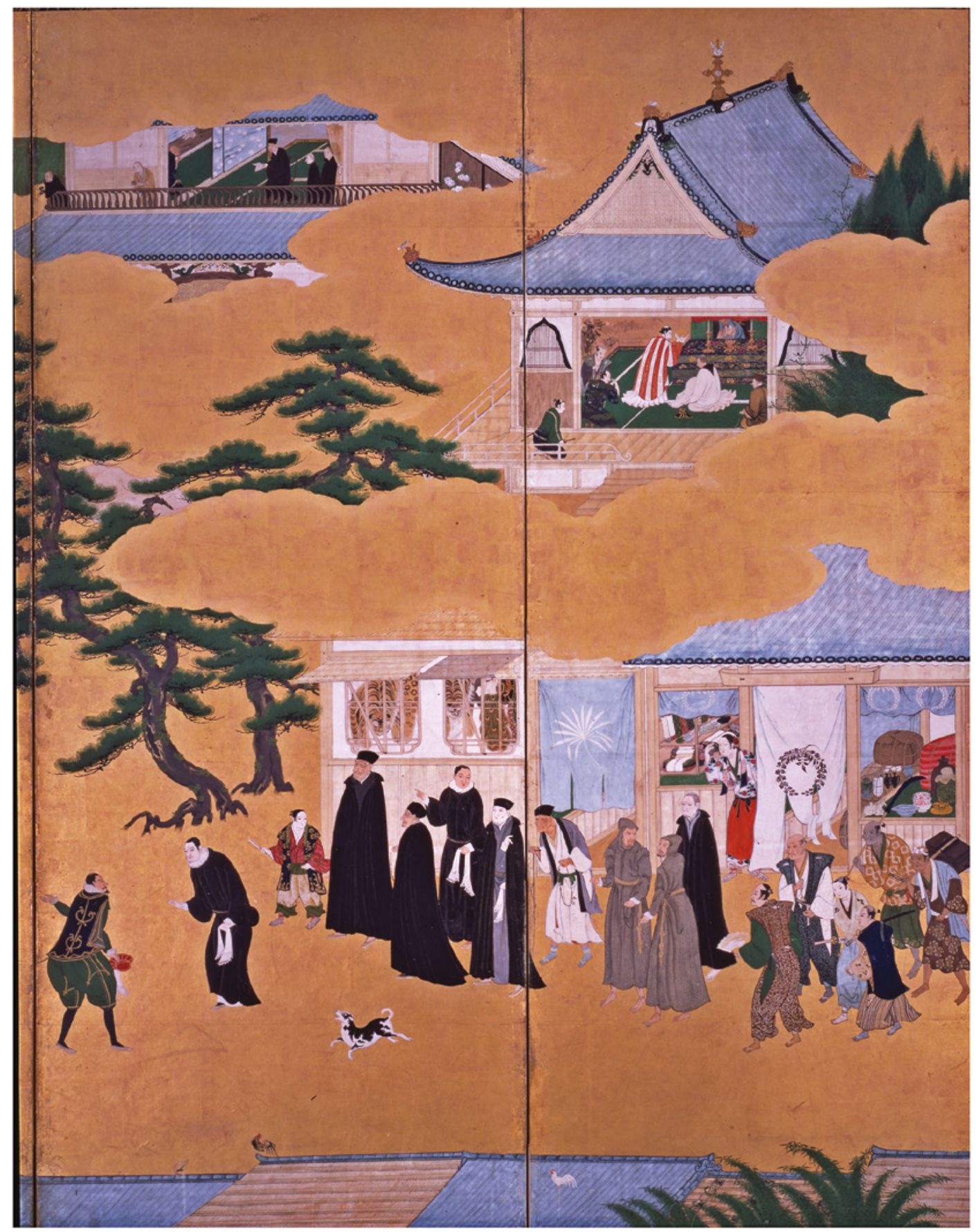

FIGURE 1.9 Kanō Naizen, Departure of a Ship from a Western Port and Arrival of a Ship in a Japanese Port, detail of right third of bottom screen, late sixteenth-early seventeenth century, pair of six-part screens, Japanese colors and gold leaf on paper. Kobe, Kobe City Museum PHOTO: (C) KOBE CITY MUSEUM 
Society in $1773 .{ }^{21}$ The tone could be satirical, as in an English seventeenthcentury woodcut Title Page for a secretly printed book by John Taylor (15801653), A Delicate, Dainty, Damnable Dialogue, between the Devill and a Jesuite (London: I.H. [Thomas Banks], 1642), where the Jesuit priest goes so far as to share a table with the devil, hand of reason countenancing black claw as a caution against the slippery slope of tolerance (fig. 1.10). Taylor's barb parodies the Jesuit reputation for carefully honed rhetoric, which pundits panned as specious rationalizations, leading to charges of casuistry. Jesuits were denounced as dissemblers, liars, and spies, an association still preserved in the Merriam-Webster Dictionary's definition of the adjective "jesuitical" as "one given to intrigue or equivocation."22 In an Allegory of the Church, an eighteenth-century Peruvian artist was yet more explicit in how the putative partnership between the devil and a Jesuit could disintegrate quickly: a horned figure hoists his alleged ally into a cauldron of fire to the consternation of an observant angel (fig. 1.11). Mary and the Christ Child are enthroned on a colonial carpet in the midst of a rocky Andean landscape before a crumbling cathedral, while a guardian angel leads a native woman to them in a pointed warning of the certain demise of a church that neglects indigenous communities. Even scathing critiques must be valued as critical resources for the light they shed on how Jesuits and their actions were viewed by contemporaries.

Other Jesuit-related objects candidly advertise a connection to the Society, like the many items that possess the monogram "IHS," an abbreviation of the Greek name of Jesus. European paintings transported by Jesuits around the world could be physically and conceptually reframed by local artisans under the Society's imprimatur, as in the pediment of a urushi lacquerware frame of a Madonna and Child Hanging Shrine (c.1583-1614), and this insignia was

21 "Anti-Jesuitism, Enlightenment, and the Suppression," in Županov, Oxford Handbook of the Jesuits, 831-949, esp. Sabina Pavone, "Anti-Jesuitism in a Global Perspective," 833-54; Pierre Antoine Fabre and José Eduardo Franco, "The Dynamics of Anti-Jesuitism in the History of the Society of Jesus," in Jesuit Historiography Online, ed. Robert A. Maryks (Leiden: Brill, 2018); http://dx.doi.org/10.1163/2468-7723_jho_COM_19253O (accessed March 13, 2021); Dale Van Kley, Reform Catholicism and the International Suppression of the Jesuits in Enlightenment Europe (New Haven: Yale University Press, 2018); Michael Niemetz, Antijesuitische Bildpublizistick in der Frühen Neuzeit: Geschichte, Ikonographie und Ikonologie, Jesuitica: Quellen und Studien zu Geschichte, Kunst, und Literatur der Gesellschaft Jesu im deutschsprachigen Raum 13 (Regensburg: Schnell \& Steiner, 2008).

22 "Jesuit," Merriam-Webster; https://www.merriam-webster.com/dictionary/Jesuit (accessed March 13, 2021). 


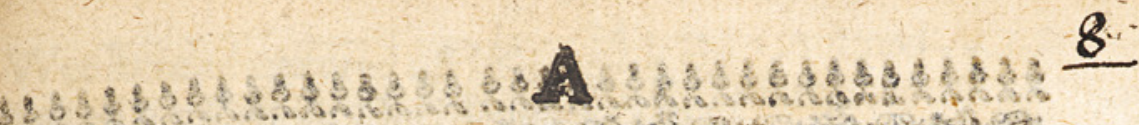
Delicate, Dainty, Daminable D I A L O G V E. Between the:Devilland a Jefuite:

\section{Dy robx Taylor:}

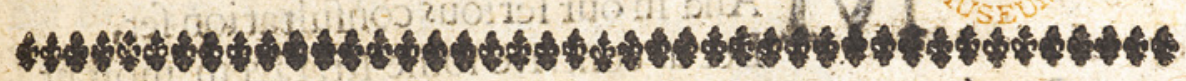

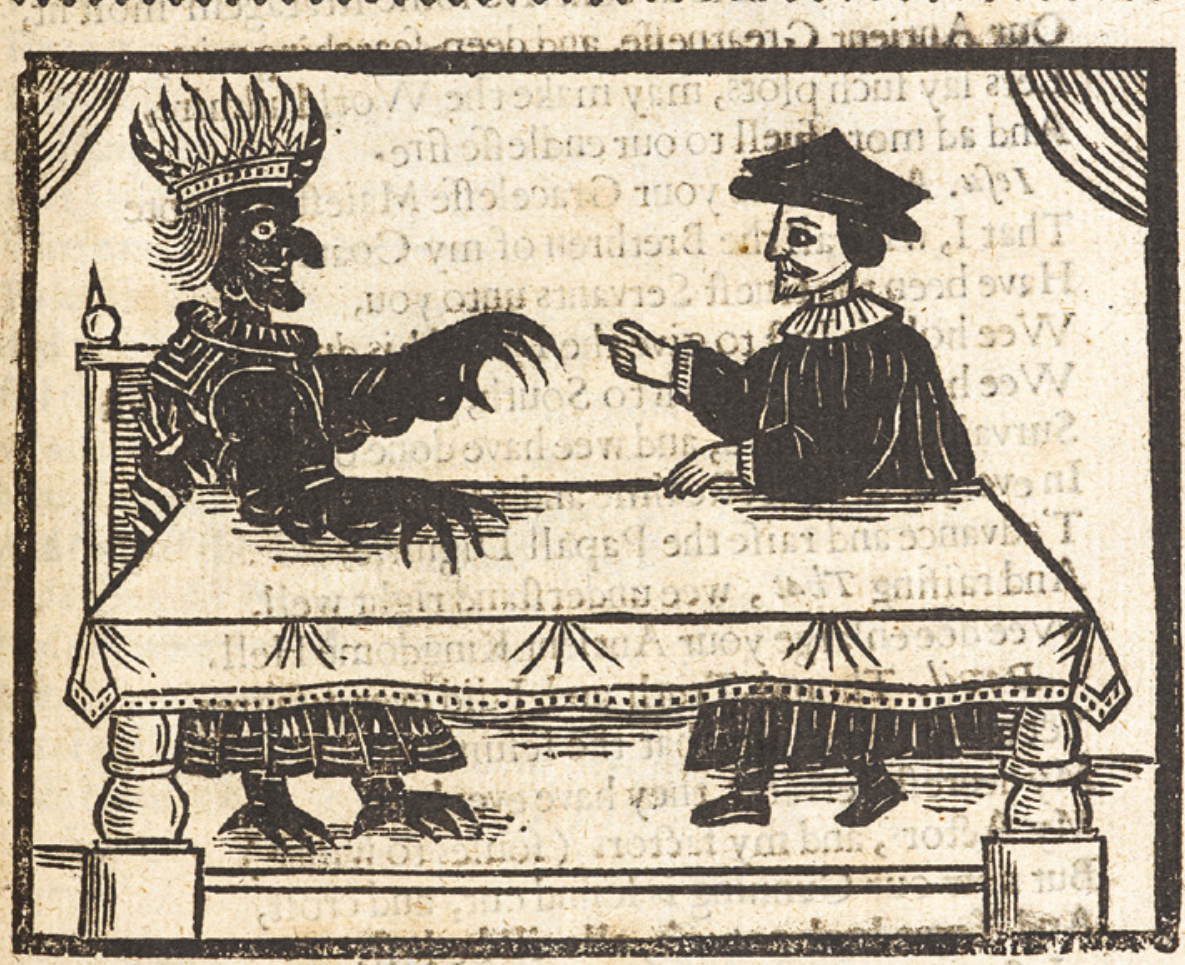

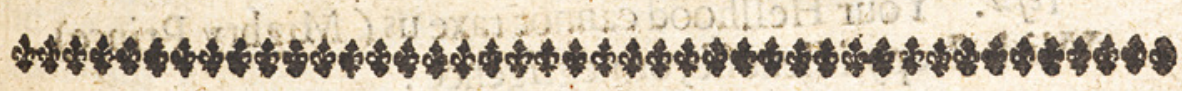

S2YY

I. $N D O N$,

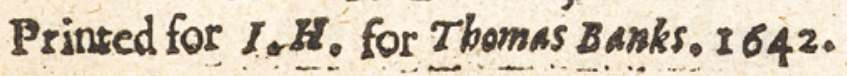

FIGURE 1.10 Title Page, 1642, woodcut, in John Taylor, A Delicate, Dainty, Damnable Dialogue,

between the Devill and a Jesuite (London: I.H. [Thomas Banks], 1642) (inv. no. F6o112-12,

Shelfmark: E.142.[8]). London, by kind permission of the British Library

PHOTO: (C) THE BRITISH LIBRARY BOARD 


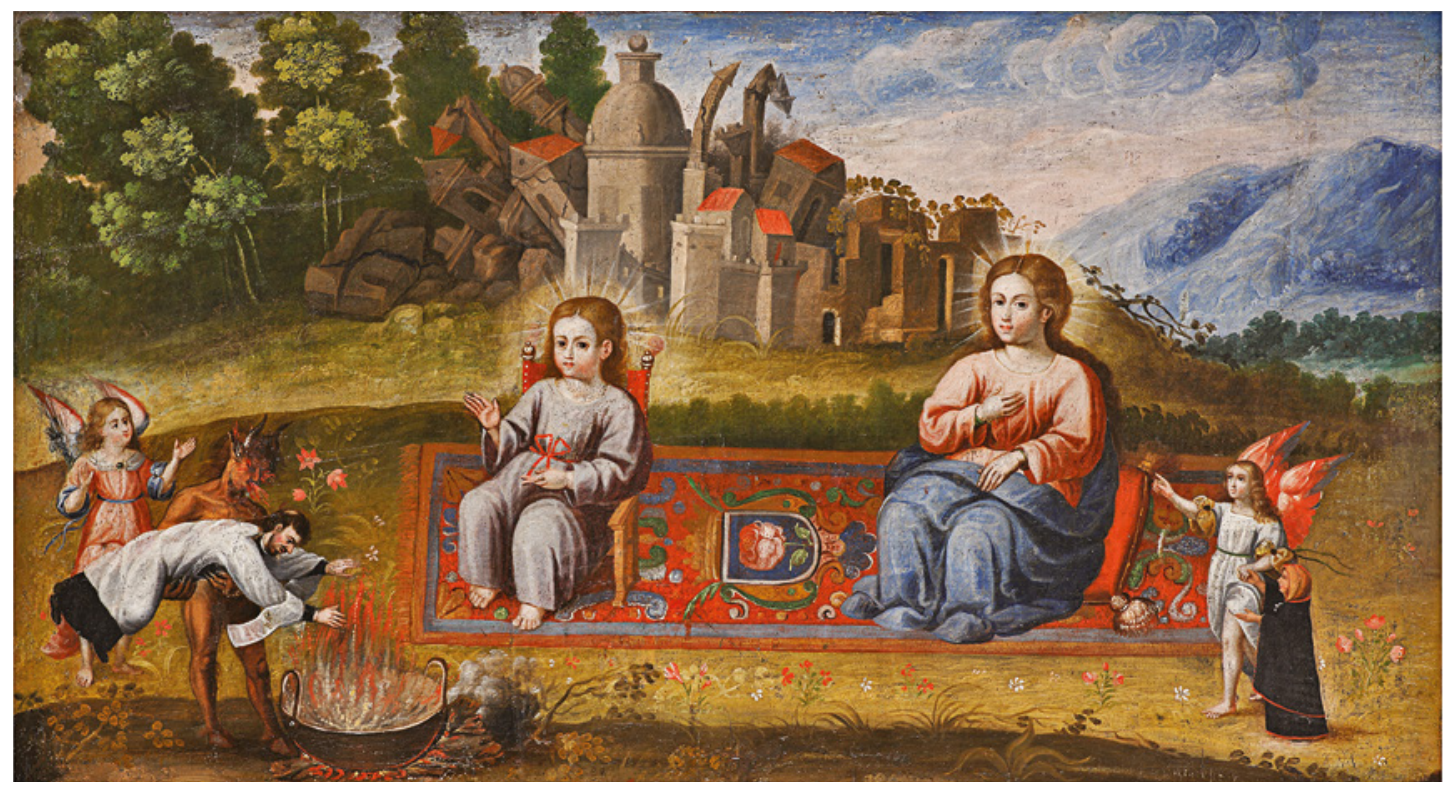

FIGURE 1.11 Peruvian Artist, Allegory of the Church, eighteenth century, oil on canvas. Lima, Colección Barbosa-Stern

(C) COLECCIÓN BARBOSA-STERN. PHOTO: DANIEL GIANONNI

regularly emblazoned on everyday objects, like missal stands and writing boxes (fig. 1.12). ${ }^{23}$ In effect, the "IHS" initials acted as the visual equivalent to the wax Seal of the Superior General of the Society of Jesus (c.1550), affixed to official Jesuit documents, whose moon and stars refer to the universal worship stirred by the name of Jesus in Philippians 2:10 (fig. 1.13). ${ }^{24}$ On a practical level,

23 For example: Japanese Artist, Folding Missal Stand, c.1590-1614, lacquerware cypress (hinoki) wood, gold, silver, and mother of pearl (inv. no. E76703), Salem, Peabody Essex Museum; Japanese Artist, Writing Box, c.159o-1614, lacquerware wood, gold, and silver, Osaka, Namban Bunkakan. Pedro Dias, Arte de Portugal no mundo:Japão (Lisbon: Público, 2008), 53-58; Ana de Castro Henriques, ed., Portugal and the World in the 16th and 17th Centuries, exh. cat. (Lisbon: Museu Nacional de Arte Antiga, 2009), 363-64; Victoria Weston, ed., Portugal, Jesuits, and Japan: Spiritual Beliefs and Earthly Goods, exh. cat. (Boston: McMullen Museum of Art, Boston College, 2013), 117-21.

24 The abbreviation "IHS" was disseminated throughout Europe by the Observant Franciscan preacher Bernardino of Siena (d.1444) to honor the cult of the Holy Name of Jesus with a reference to the Christological hymn of Phil 2:3-10; it reputedly decorated the crib of the young Loyola. Franco Mormando, "IHS Monogram," in The Cambridge Encyclopedia of the Jesuits, ed. Thomas Worcester, s.J. (Cambridge: Cambridge University Press, 2017), 377-78; Vincenzo Pacelli, "Il 'monogramma' bernardiniano: Origine, diffusione et sviluppo," in S. Bernardino di Siena, predicatore e pellegrino: Atti del Convegno nazionale di 


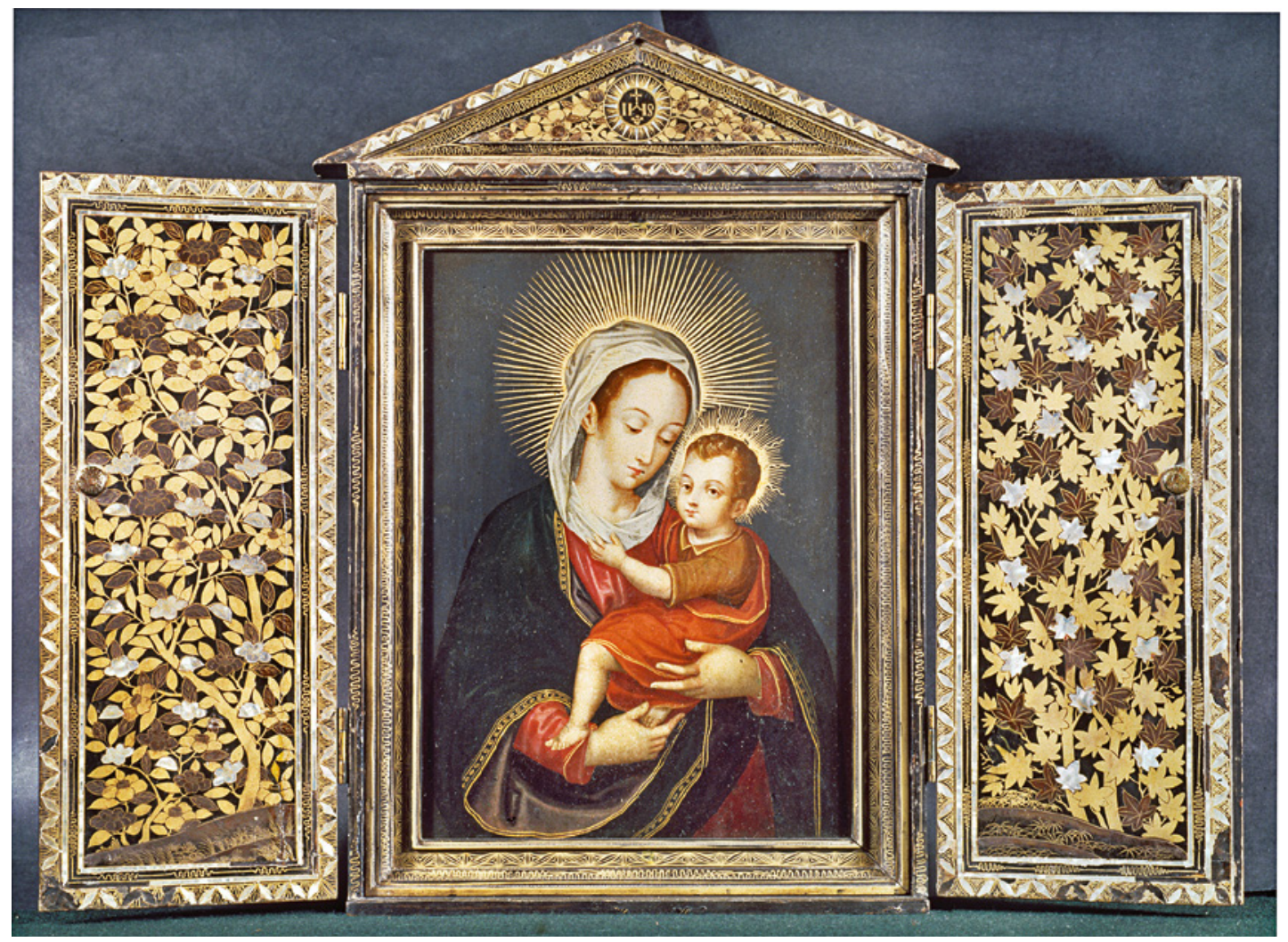

FIGURE 1.12 Italian Artist (painting) and Japanese Artist (frame), Madonna and Child Hanging Shrine, c.1583-1614, oil on copper in lacquerware wooden frame with gold, silver, and mother of pearl. Sardoal, Santa Casa da Misericórdia do Sardoal

(C) SANTA CASA DA MISERICÓRDIA DO SARDOAL. PHOTO: NUNO FEVEREIRO

a conspicuous imprint, whether cipher or seal, identified a diverse group of objects that had been made, distributed, and reformatted by the Society, while from a theoretical perspective, it drove home the order's commitment to the naming of Jesus and the efficacy of its rhetorical invocation, broadcasting the idea seen in Pozzo's St. Ignatius Receiving the Banner with the Monogram of the Name of Jesus from the Resurrected Christ in every bandwidth large and small (fig. 1.1). In the desire to surmount the distractions of individual circumstance,

studi bernardiniani, Maiori, 20-22 giugno, 1980, ed. Francesco D’Episcopo (Galatina: Congedo Editore, 1985), 253-6o. 


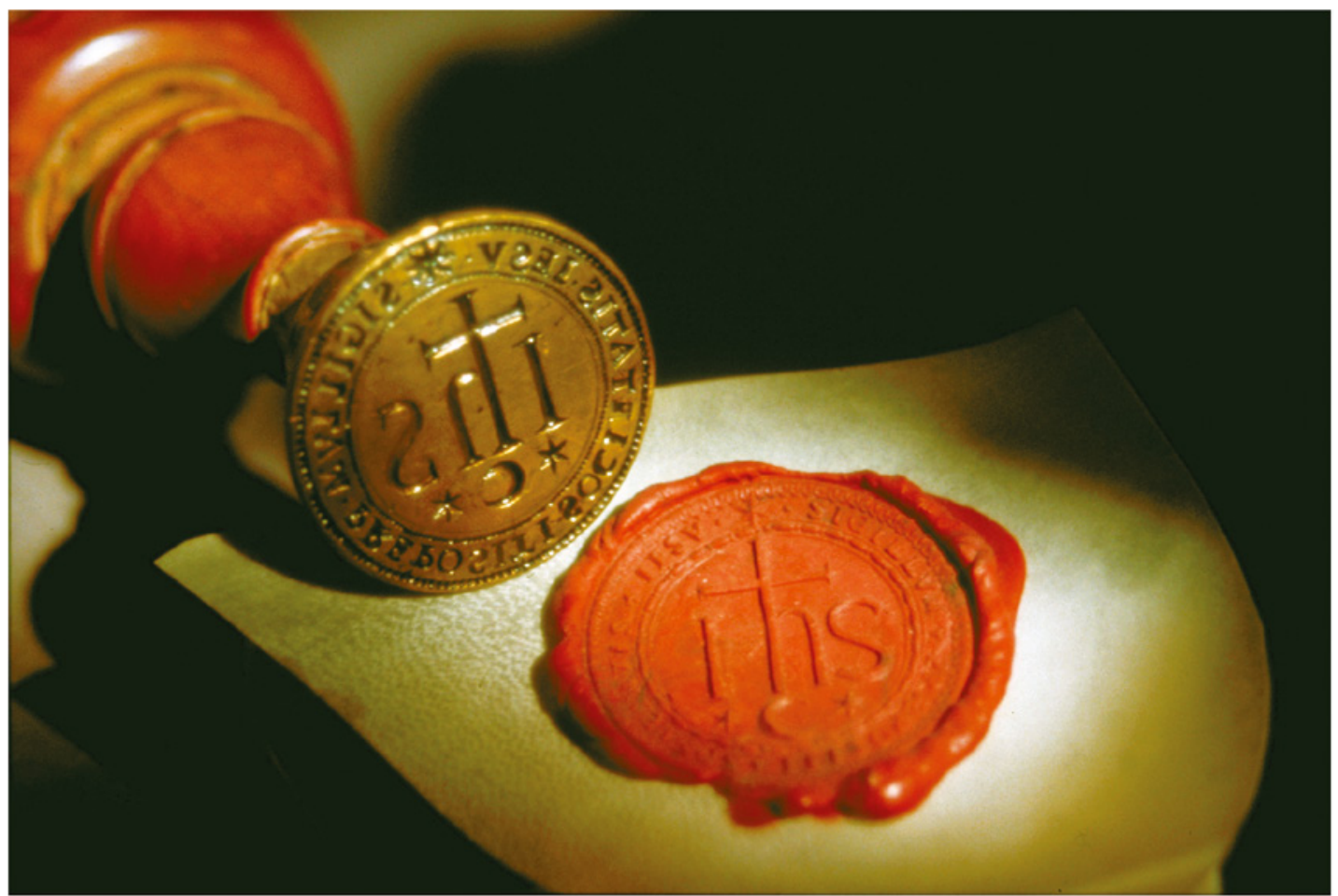

FIGURE 1.13 Anonymous, Seal of the Superior General of the Society ofJesus, c.1550, bronze and wood. Rome, Archivum Romanum Societatis Iesu

PHOTO: (C) ARCHIVUM ROMANUM SOCIETATIS IESU

the application of Jesuit signs was no different from the attempt to craft a collective identity from the contributing personae of the late sixteenth-century First Companions of St. Ignatius, whose group portrait, literally and figuratively, was vital to the retrospective burnishing of the early Society with providential causation (fig. 1.14). ${ }^{25}$ Items stamped by Jesuit custom afford insight into the complexities of negotiating cultural and historical identity that confronted a new order on the world stage.

25 Pierre Antoine Fabre, "The 'First Fathers' of the Society of Jesus," in Županov, Oxford Handbook of the Jesuits, 3-22. 


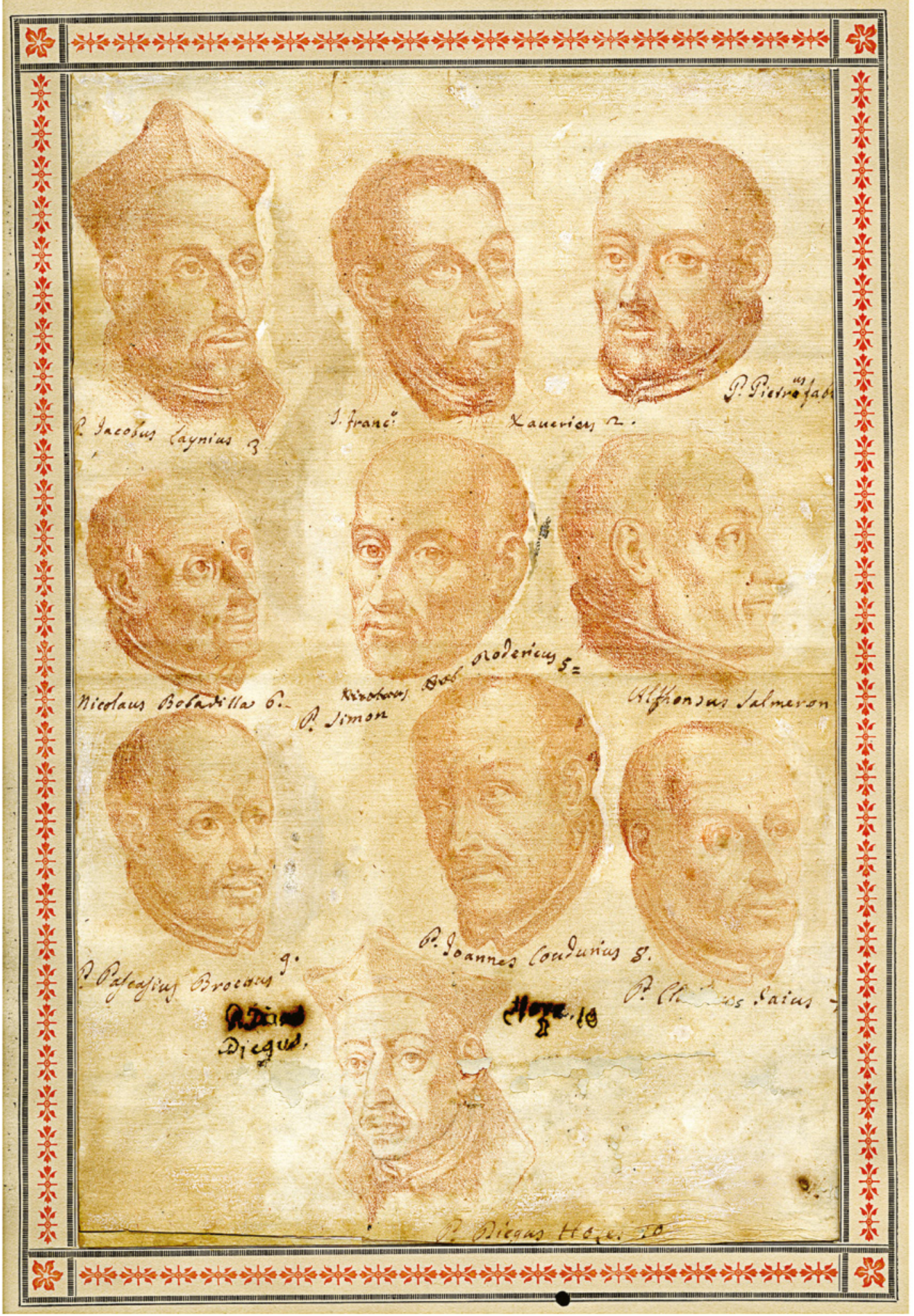


A closer look at the constituents of Jesuit art thus registers a remarkably disparate group. Objects can range from multimedia church installations to a book-sized piece of paper or broadsheet, from oil painting on wood, canvas, and copper to colored inks on paper, from the hard shells of lacquerware to the hazy silhouettes of chalk drawing that threaten to disintegrate at the slightest touch. They can be made by Jesuits, commissioned and printed at the behest of the order's administrators, or only connected to the Society by their usage. Jesuits cultivated particular holy images and transported art for promotional, devotional, catechetical, and didactic purposes. They served not only as makers and agents of art, but also as subject matter in their own right, both as figures of intrigue and rebuked villains. The Jesuit connection could function as a statement of ownership, an expression of cultural engagement, and an ideological venture. There was no typical kind of Jesuit art: the category defies a set of artists, one country or region, and a sole period, style, or medium. If there is any commonality extant in the Jesuit relationship to art across such a dizzying array of objects, it is of hands traversing the life of the object: hands that make and operate, hands that carry and dispense, hands that gesture and flail. The exceptional range of art demands a broad casting of the net - in terms of the kinds of objects, issues, and geographies of fabrication under scrutiny-in order to construct a more complete picture of how the many roles of early modern Jesuits in art-making impacted the history of art.

\subsection{Context}

The discipline's silence on these objects, until recently, can be traced to the art historical context of Jesuit art, where its range of sources problematized conventional modes of inquiry. In the 1970s, the re-imagining of the intellectual inheritance of the first half of twentieth-century art history created the necessary preconditions for the expansion of the oeuvre. With Baroque Art: The Jesuit Contribution (1972), Rudolf Wittkower (1901-71) gathered specialists on the Church of the Gesù to ascertain whether Jesuits shaped the distinctive style of the baroque, or vice versa, if the age's virtuosi defined the artistic undertakings of the Society. ${ }^{26}$ Almost fifty years later, the anxiety of influence may have a nostalgic ring, but at the time this anthology was forward-looking for its presentation of an alternative to a building biography by considering the thematic

26 Wittkower and Jaffe, Baroque Art.

$\leftarrow \quad$ FIGURE 1.14

Anonymous, The First Companions of St. Ignatius, late sixteenth century, red chalk on paper. Rome, Archivum Romanum Societatis Iesu PHOTO: (C) ARCHIVUM ROMANUM SOCIETATIS IESU 
links that could override the lack of stylistic unity across interior programs and discrete media. ${ }^{27}$ Its essays drew upon contemporary texts to recover the lost associations of artists, patrons, and viewers, a method of art historical analysis explored in the aftermath of the Second World War to combat frustration with the hermetic segregation of form from social issues. Erwin Panofsky's (18921968) introduction to Studies in Iconology: Humanistic Themes in the Art of the Renaissance (1939), complete with a step-by-step guide for its application, supplied the infrastructure for the iconological study of art, as exemplified by "Perspective as Symbolic Form" (1924) or Early Netherlandish Painting (1947), where his theory of "disguised symbolism" revealed how everyday objects could be suffused with hidden meaning. ${ }^{28}$ Symbolic criticism would come to dominate much of twentieth-century art history, with Jesuit iconography featured as an early example of post-Tridentine iconology by Émile Mâle (18621954) in $1932 .{ }^{29}$ Iconology was envisioned as a tool to support the encyclopedic scope of the humanist art historian and ensure the analysis of the object in the world, or more aptly, the world within the object. ${ }^{30}$

27 For an introduction to the prominence of stylistic criticism in art history-with particular attention to Johann Joachim Winckelmann's (1717-68) Geschichte der Kunst des Altertums (History of ancient art, 1764) and Heinrich Wölfflin's (1864-1945) Kunstgeschichte Grundbegriffe (Principles of art history, 1915) —including a glossary of art historical vocabulary, see Eric Fernie, ed., Art History and Its Methods: A Critical Anthology (London: Phaidon Press, 1995), 68-76, 127-51; David Irwin, ed., Winckelmann: Writings on Art (London: Phaidon Press, 1972), 104-7, 113-22; Johann Joachim Winckelmann, Geschichte der Kunst des Altertums (Dresden: Walther, 1764); Winckelmann, The History of Ancient Art, trans. G. Henry Lodge (Boston: Houghton Mifflin, 1880); Heinrich Wölfflin, Kunstgeschichte Grundbegriffe: Das Problem der Stilentwicklung in der neueren Kunst (Munich: Friedrich Bruckmann, 1915); Wölfflin, Principles of Art History: The Problem of the Development of Style in Later Art, trans. Marie D.M. Hottinger (New York: Dover, 1950).

28 Erwin Panofsky, Early Netherlandish Painting: Its Origins and Character, 2 vols. (Cambridge, MA: Harvard University Press, 1947); Panofsky, "Iconography and Iconology: An Introduction to the Study of Renaissance Art (1939)," Meaning in the Visual Arts (Chicago: University of Chicago Press, 1982), 26-54; Panofsky, Perspective as Symbolic Form, trans. Christopher S. Wood (New York: Zone Books, 2012); Panofsky, Studies in Iconology: Humanistic Themes in the Art of the Renaissance, rev. ed. (London: Routledge, 2019).

29 Émile Mâle, L'art religieux de la fin du XVI siècle, du XVII e siècle et du XVIII e siècle: Étude sur l'iconographie après le Concile de Trente, Italie-France-Espagne-Flandres, rev. ed. (Paris: Librairie Armand Colin, 1951).

30 Fernie, Art History and Its Methods, 181-95; Erwin Panofsky, "The History of Art as a Humanistic Discipline (1940)," Meaning in the Visual Arts, 1-25; Panofsky, "Iconography and Iconology," 26-54; Panofsky, Studies in Iconology. 
By the 1980s, art historians began to urge the field to acknowledge that not only masterpieces, but also the less famous and often anonymous works of material culture were equally valid subjects for analysis. In other words, the Jesuit commitment to art reached beyond works like the Gesù. Art history was reframed as not simply the study of canonical works of art based on a subjective appraisal of beauty and style; rather, it should be an intellectually rigorous and comprehensive quest to understand everything that can be seen (or triggers sight), all that lies within a visual purview. It is not always recalled that religious art played a leading role in this development, but church decoration had long relied upon the craftsmanship of the decorative arts, and popular devotion frequently featured imagery as an essential component of its rituals, where the cultic function of an object outweighed any aesthetic deliberation. A prescient indication that Jesuit artistic production reached beyond accepted masterpieces can be found in the post-war writings on Jesuit architecture by Pietro Pirri, S.J. (1881-1969) and Pio Pecchiai, S.J. (1882-1965), whose attention to the woodwork of church interiors underscored the value of the art of masters less well known today. ${ }^{31}$ The number of books that have emerged on Jesuit art since the material culture revolution, from emblem studies to local idioms of Christian subject matter and churches off the beaten track, exceed the parameters of this study, but it suffices to note that a wide-lens view became the gold standard for the discipline of art history at large.

During the 199os, it became clear that if the history of art was not concentrated on the examination of masterpieces alone, the corollary of whether style was the ultimate barometer of objects neatly followed. Designations like "baroque" art had begun to seem crusty and outdated, a decadent period piece in its taxonomic and cultural constraints, where an assertion could turn on the flick of a wrist or the flight of a line. It had become too closely connected with the fickle snobberies of connoisseurial pronouncements on quality and taste, stimulating art historians to explore other approaches to the interpretation of art. "Early modern" art became a generally accepted solution to indicate studies with an interdisciplinary appeal, and it was a name exceptionally well suited to orders like the Society of Jesus, whose engagement with art began during the sixteenth century's liminal period of transition from the Renaissance

31 Pecchiai, Gesù di Roma; Pirri, Giovanni Tristano e i primordi della architettura gesuitica; Pietro Pirri, S.J., Giuseppe Valeriano S.I., architetto e pittore 1542-1596 (Rome: Institutum Historicum Societatis Iesu, 1970); Pirri, "Intagliatori gesuiti italiani dei secoli XVI e XVII," Archivum historicum Societatis Iesu 21 (1952): 3-59. 
to the baroque era and flourished well into the rococo period of the eighteenth century in defiance of the dictates of any one style. Books like Gauvin Bailey's Between Renaissance and Baroque:Jesuit Art in Rome, 1565-1610 (2003) situated the Jesuit commitment to art precisely in the analytic gaps of what came to be seen as an initially constructive, if increasingly restrictive, classification system. ${ }^{32}$ But if "early modern" seemed to err too much on the side of the historical for visual trends, at times endowing a period's central events with undeserved relevancy, the idea of the "baroque" could be reclaimed as a chronological division for other measures. Evonne Levy's book, Propaganda and the Jesuit Baroque (2004), freed the discourse from the gymnastic contortions needed to make stylistic groupings fit such divergent works by redirecting attention to the functional typologies of architecture..$^{33}$ When the internal contradictions of customary assessments had become too conspicuous to ignore, Jesuit art placed pressure on the fault lines of a field that recast baroque art in accordance with revised loci for the cultural authority of art.

From the 2ooos onward, scholars perceived that the shift from masterpieces to material culture, from stylistic to functional criteria - when art historians looked beyond the accepted corpus to see the lives of objects as inherently compelling, rather than as second-rate cognates of the monuments of western art-highlighted the input of extra-European artistic invention in western art. Sometimes the point that European art should be placed within its original global context has been misunderstood as non-European art supplanting European art. This distinction is meaningful, because it concerns how western art can be reimagined productively in a global frame of reference; it is certainly not a call for its replacement. Art historians have come to differentiate between "global" and "world" objects. ${ }^{34}$ The creation of "global" art can take place anywhere but assumes a degree of contact between multiple cultures,

32 James Ackerman, "The Gesù in the Light of Contemporary Church Design," in Wittkower and Jaffe, Baroque Art, 15-28; Bailey, Between Renaissance and Baroque.

33 Levy, Propaganda and the Jesuit Baroque.

34 Hans Belting, "From World Art to Global Art: View on a New Panorama," in The Global Contemporary and the Rise of New Art Worlds, ed. Hans Belting, Andrea Buddensieg, and Peter Weibel (Cambridge, MA: MIT Press, 2013), 178-85; Mia M. Mochizuki "Connected Worlds: The World, the Worldly, and the Otherworldly; An Introduction," in The Nomadic Object: The Challenge of World for Early Modern Religious Art, ed. Christine Göttler and Mia M. Mochizuki, Intersections: Interdisciplinary Studies in Early Modern Culture 53 (Leiden: Brill, 2018), 1-34; Mochizuki, "Tsunagaru chijō-sekai, sezoku-sekai to seinarusekai," in Utsurō keishō to shikaku geijutsu: Kobayashi Yoriko-sensei taishoku kinen ronbun-shū, ed. Junko Aono et al. (Tokyo: Yasaka Shobo, 2019), 13-51. 
whether externally, from political state to state and geographic region to region, or internally, within a heterogeneous society. In contrast, "world" art generally refers to objects from non-western artistic heritages, an improvement on artisanal handicrafts in an anthropological system rooted in colonialera ethnological values, if an undercurrent of bias can still be detected in the fact that that the term is never used to interpret European art. The global reach of Jesuit art, with its many workshop outposts around the world, was brought to widespread attention by Bailey's landmark Art on the Jesuit Missions in Asia and Latin America, 1543-1773 (1999), which prioritized the contributions of four cultures in the early modern artistic production of the Society of Jesus, positioning the full scope of Jesuit art as a forum well suited to the concerns of art historians today. ${ }^{35}$

\subsection{Resources}

For the explosion in the creative arts sparked by Jesuit activity, a curious mind would do well to start with the anthologies spearheaded by John O'Malley, s.J. that surround the researcher with a tantalizing array of options, like The Jesuits: Cultures, Sciences, and the Arts, 1540-1773 (1999); The Jesuits and the Arts, 1540-1773 (2005); and The Jesuits II: Cultures, Sciences, and the Arts, 1540-1773 (2006), with introductions from the standpoints of cultural orientation, style, and iconography by O'Malley, Bailey, and Heinrich Pfeiffer, S.J. ${ }^{36}$ Exhibitions—such as Baroque, vision jésuite (Baroque, a Jesuit vision) curated by Alain Tapié in Caen (2003); Portugal, Jesuits, and Japan: Spiritual Beliefs and Earthly Goods, prepared by Victoria Weston in Boston (2013); De Augsburgo a Quito: Fuentes grabadas del arte jesuita quiteño del siglo XVIII (From Augsburg to Quito: The engraved sources for Quito's eighteenth-century Jesuit art), coordinated by Almerindo Ojeda and Alfonso Ortiz Crespo in Quito (2015); and The Holy Name: Art of the Gesù created by Linda Wolk-Simon in Fairfield, Connecticut (2018) - exhilarate with unalloyed visual bravura. ${ }^{37}$ Scholars

35 Bailey, Art on the Jesuit Missions in Asia and Latin America.

$3^{6}$ John W. O'Malley, S.J., "Saint Ignatius and the Cultural Mission of the Society of Jesus," Saints or Devils Incarnate? Studies in Jesuit History, Jesuit Studies 1 (Leiden: Brill, 2013), 225-55; O'Malley and Bailey, Jesuits and the Arts, 1540-1773; O'Malley et al., Jesuits; John W. O'Malley, s.J. et al., eds., The Jesuits II: Cultures, Sciences, and the Arts, 1540-1773 (Toronto: University of Toronto Press, 2006).

37 Almerindo E. Ojeda and Alfonso Ortiz Crespo, eds., De Augsburgo a Quito: Fuentes grabadas del arte jesuita quiteño del siglo XVIII, exh. cat. (Quito: Fundación Iglesia de la Compañia de Jesús, 2015); Alain Tapié, ed., Baroque, vision jésuite: Du Tintoret à Rubens, 
have updated knowledge on the masterpieces of Jesuit art, often with newly discovered archival information and an increased number of objects, as in accounts by Bailey on the Society's artistic centers in Rome and distant locales (1999, 2003, 2010), and by Levy on the applications of its architecture (2004).38 Other readers may choose to begin with critical editions of principal visual sources for Jesuits, like the three volumes of Jerome Nadal, S.J.: Annotations and Meditations on the Gospels, edited by Frederick Homann, S.J. (1929-2011) and accompanied by substantial essays by Walter Melion (2003-7); the Imago primi saeculi Societatis Iesv (Image of the first century of the Society of Jesus [Antwerp: Plantin Press under Balthasar Moretus, 1640]), commented on by Lydia Salviucci Insolera (2004) and in an anthology edited by O'Malley (2015); and the 1609 Illustrated Biography of Ignatius of Loyola (2008), with a foreword by O'Malley. ${ }^{39}$

If the number of general introductions to Jesuit art and architecture seem plentiful, they pale in comparison to the treasure trove of resources dedicated to particular aspects of Jesuit art. Books like Pierre Antoine Fabre's Ignace de Loyola, le lieu de l'image: Le problème de la composition de lieu dans les pratiques spirituelles et artistiques jésuites de la seconde moitié du XVI siècle (Ignatius of Loyola, the place of the image: The problem of the composition of place in Jesuit spiritual and artistic practices of the second half of the sixteenth century [1992]), Ralph Dekoninck's Ad imaginem: Statuts, fonctions et usages de l'image

exh. cat. (Caen: Musée des Beaux-Arts, 2003); Weston, Portugal, Jesuits, and Japan; Wolk-Simon, Holy Name.

38 Gauvin Alexander Bailey, The Andean Hybrid Baroque: Convergent Cultures in the Churches of Colonial Peru (Notre Dame: University of Notre Dame Press, 2010); Bailey, Art on the Jesuit Missions in Asia and Latin America; Bailey, Between Renaissance and Baroque; Levy, Propaganda and the Jesuit Baroque; Schwager and Schlimme, "Chiesa del Gesù di Roma," 279-99.

39 Frederick A. Homann, S.J., ed. and trans., Jerome Nadal, S.J.: Annotations and Meditations on the Gospels, 3 vols. (Philadelphia: St. Joseph's University Press, 2003-7); Lydia Salviucci Insolera, L'imago primi saeculi (1640) e il significato dell'immagine allegoria nella Compagnia di Gesù: Genesi e fortuna del libro (Rome: Editrice Pontificia Università Gregoriana, 2004); Susanne Lang, Bilder zur Mission: Die jesuitische Literatur und ihre Illustration (Petersberg: Michael Imhof Verlag, 2012); Joseph P. Lea, ed., Jerome Nadal, S.J.: Annotations and Meditations on the Gospels; Cumulative Index (Philadelphia: St. Joseph's University Press, 2014); John W. O'Malley, S.J., "The Many Lives of Ignatius of Loyola: Future Saint," Saints or Devils Incarnate?, 257-97; O'Malley, ed., Art, Controversy, and the Jesuits: The Imago primi saeculi (1640), Early Modern Catholicism and the Visual Arts Series 12 (Philadelphia: St. Joseph's University Press, 2015); O'Malley, ed., Constructing a Saint through Images: The 1609 Illustrated Biography of Ignatius of Loyola (Philadelphia: St. Joseph's University Press, 2008). 
dans la littérature spirituelle jésuite (In the image: The statutes, functions, and uses of the image in Jesuit spiritual literature [2005]), and Melion's The Meditative Art: Studies in the Northern Devotional Print, 1550-1625 (2009) have plumbed Jesuit writings, from letters to literature, to reconstruct the overarching principles of Jesuit imagery as an inspiration for meditation. ${ }^{40}$ Others, like Sibylle Appuhn-Radtke (1988) and Louise Rice (2000), Rose Marie San Juan (2011), and Andrew Horn (2019), have traced discrete phenomena, such as thesis prints, engravings implicated by travel, and religious theater respectively, to chart the scope of the Jesuit engagement with art. ${ }^{41}$ Jesuit churches acted as spaces of reform, marking memorial grounds (Thomas Lucas, S.J., 199o, 1997), motivating worship through an appeal to the senses (Jeffrey Chipps Smith, 2002), evangelizing at home and abroad (Levy, 2004), and codifying a Jesuit identity (Steffen Zierholz, 2019). ${ }^{42}$ Together with the ongoing work of Richard Bösel, architectural analysis, the initial locus of Jesuit art criticism, endures

40 Ralph Dekoninck, Ad imaginem: Statuts, fonctions et usages de l'image dans la littérature spirituelle jésuite (Geneva: Droz, 2005); Pierre Antoine Fabre, Ignace de Loyola, le lieu de l'image: Le problème de la composition de lieu dans les pratiques spirituelles et artistiques jésuites de la seconde moitié du XVI siècle (Paris: J. Vrin, 1992); Fabre, "Quelques éléments pour une théorie jésuite de la contemplation visuelle," in Tapié, Baroque, vision jésuite, 27-38; Homann, Jerome Nadal, S.J.; Lea, Jerome Nadal, S.J.; Walter S. Melion, "Introduction: The Jesuit Engagement with the Status and Functions of the Visual Image," in Jesuit Image Theory, ed. Wietse de Boer, Karl A.E. Enenkel, and Walter S. Melion, Intersections: Interdisciplinary Studies in Early Modern Culture 45 (Leiden: Brill, 2016), 1-52; Melion, The Meditative Art: Studies in the Northern Devotional Print, 1550-1625, Early Modern Catholicism and the Visual Arts Series 1 (Philadelphia: St. Joseph's University Press, 2009).

41 Sibylle Appuhn-Radtke, Das Thesenblatt im Hochbarock: Studien zu einer graphischen Gattung am Beispiel der Werke Bartholomäus Kilians (Weißenhorn: Anton H. KonradVerlag, 1988); Andrew Horn, Andrea Pozzo and the Religious Theatre of the Seventeenth Century, Early Modern Catholicism and the Visual Arts Series 18 (Philadelphia: St. Joseph's University Press, 2019); Louise Rice, "Jesuit Thesis Prints and the Festive Academic Defense at the Collegio Romano," in O'Malley et al., Jesuits, 148-69; Rice, "Los pliegos de tesis jesuitas y las sustentaciones académicas festivas en el Collegio Romano," trans. Maricruz González C., in Ojeda and Ortiz Crespo, De Augsburgo a Quito, 67-80; Rose Marie San Juan, Vertiginous Mirrors: The Animation of the Visual Image and Early Modern Travel (Manchester: Manchester University Press, 2011).

42 Levy, Propaganda and the Jesuit Baroque; Thomas M. Lucas, s.J., Landmarking: City, Church, and Jesuit Urban Strategy (Chicago: Loyola Press, 1997); Lucas, ed., Saint, Site, and Sacred Strategy: Ignatius, Rome, and Jesuit Urbanism, exh. cat. (Vatican City: Biblioteca Apostolica Vaticana, 199o); Jeffrey Chipps Smith, Sensuous Worship:Jesuits and the Art of the Early Catholic Reformation in Germany (Princeton: Princeton University Press, 2002); Steffen Zierholz, Räume der Reform: Kunst und Lebenskunst der Jesuiten in Rom, 1580-1700 (Berlin: Gebr. Mann Verlag, 2019). 
as a force, with recent research projects coordinated by Piet Lombaerde on the Jesuit Church of St. Charles Borromeo in Antwerp (2008), directed by Johannes Terhalle on Sant'Andrea al Quirinale (2011), and led by María Isabel Álvaro Zamora (2012), whose group has systematically compared the plans and documents of Jesuit architecture in six countries, as Jesuit sites around the world have begun to be studied. ${ }^{43}$ Wietse de Boer, Karl Enenkel, and Melion launched a probe into the Jesuit investment in the imago, and a growing number of findings, including my own research, have detailed the pictorial stakes when Jesuits pushed the assumptions of form to their logical conclusions. ${ }^{44}$

43 Luisa Elena Alcalá, ed., Fundaciones jesuíticas en Iberoamérica (Madrid: Fundación Caja Madrid and Ediciones El Viso, 2002); Bailey, Andean Hybrid Baroque; Bösel, Jesuitenarchitektur in Italien, 1540-1773; Bösel, Orazio Grassi: Architetto e matematico gesuita; Un album conservato nell'Archivio della Pontificia Università Gregoriana a Roma (Rome: Argos, 2004); Richard Bösel and Herbert Karner, Jesuitenarchitektur in Italien, 1540-1773: 2. Die Baudenkmäler der mailändischen Ordensprovinz (Vienna: Verlag der Österreichischen Akademie der Wissenschaften, 2007); Denis De Lucca, Jesuits and Fortifications: The Contributions of the Jesuits to Military Architecture in the Baroque Era (Leiden: Brill, 2012); Sofia Diniz, "Jesuit Buildings in China and Japan: A Comparative Study," Bulletin of Portuguese-Japanese Studies 3 (2001): 107-28; Diniz, "A arquitectura da Companhia de Jesus no Japão: A criação de um espaço religioso cristão no Japão dos séculos XVI e XVII" (MA thesis, Universidade Nova de Lisboa, 2007); Víctor M. Fernández et al., The Archaeology of the Jesuit Missions in Ethiopia (1557-1632), Jesuit Studies 10 (Leiden: Brill, 2017); Paulo Varela Gomes, Whitewash, Red Stone: A History of Church Architecture in Goa (New Delhi: Yoda Press, 2011); Evonne Levy, "Architecture and Religion in Seventeenth-Century Rome," Studiolo 2 (2003): 219-53, here 231-35; Levy, "Early Modern Jesuit Arts and Jesuit Visual Culture," Journal of Jesuit Studies 1, no. 1 (2014): 66-87, here 67-75; Piet Lombaerde, ed., Innovation and Experience in the Early Baroque in the Southern Netherlands: The Case of the Jesuit Church in Antwerp (Turnhout: Brepols, 20o8); [Maria] Cristina Osswald, Written in Stone:Jesuit Buildings in Goa and Their Artistic and Architectural Features (Saligao: Goa 1556 and Golden Heart Emporium Book Shop, 2013); José Pereira, The Architecture of Portuguese India (New Delhi: Books \& Books, 1995); José Pereira, Churches of Goa (New Delhi: Oxford University Press, 2001); Sale, Pauperismo architettonico e architettura gesuitica; Sale, "Architectural Simplicity and Jesuit Architecture," 27-44; Sale, "Design of the Gesù in Rome," 45-62; Schwager and Schlimme, "Chiesa del Gesù di Roma," 279-99; Johannes Terhalle, S. Andrea al Quirinale von Gian Lorenzo Bernini in Rom (Weimar:Verlag und Datenbank für Geisteswissenschaften, 2011); Lianming Wang, Jesuitenerbe in Peking: Sakralbauten und transkulturelle Räume, 1600-180o (Heidelberg: Universitätsverlage Winter, 2020); María Isabel Álvaro Zamora, Javier Ibáñez Fernández, and Jesús Criado Mainar, eds., La arquitectura jesuítica: Actas del simposio internacional celebrado en Zaragoza el 9, 10, y 11 de diciembre de 2010 (Zaragoza: Institución "Fernando el Católico," 2012).

44 De Boer, Enenkel, and Melion, Jesuit Image Theory; Kobayashi-Sato and Mochizuki, Gurōbaru jidai no yoake, 122-210, 244-52; Mia M. Mochizuki, "The Diaspora of a Jesuit Press: Mimetic Imitation on the World Stage," in Illustrated Religious Texts in the North of Europe, 1500-180o, ed. Feike Dietz et al. (Farnham: Ashgate, 2014), 113-34; Mochizuki, "Fukusei gijutsu jidai ni okeru shūkyōga," 273-97; Mochizuki, "A Global Eye: The 
Continuing vitality is attested by an issue of the Journal of Jesuit Studies (2019), guest edited by Alison Fleming, with examples of Jesuit visual culture from early modern Italy, Peru, and Mexico. ${ }^{45}$

Excellent reviews of the state of research on Jesuit art have been compiled. In the wake of Jesuit Michel de Certeau's (1925-86) call to rethink historical operations, Fabre offered a brief, but still germane sketch of the Society's primary areas of artistic achievement (1999): the experience of thinking with imagery, the interplay of the arts, the creation of mission art, and the publication of illustrated books. ${ }^{46}$ Dekoninck approached the invention of a Jesuit image by connecting the conceptualization of art in the aftermath of Trent with the illustrated books flowing out of Antwerp (French 2005, English 2017). ${ }^{47}$ Jesuit art merited a bibliographic article by Levy in the first issue of the Journal of Jesuit Studies in 2014, where she singled out advances in three areas: the architecture of Rome and beyond, the meditative engagement with images, and the impact of the Spiritual Exercises on Jesuit pictorial programs. ${ }^{48}$ Future researchers, she advised, should examine Jesuit art in relation to contemporary art theory and

Perception of Place in a Pair of Tokugawa World Map Screens," Japan Review 29 (2016): 69-119; Mochizuki, "Global na me: Tokugawa-ke Bankoku Ezu byobu ni okeru basyo no ninshiki," Bijutsushi Ronsō: Tōkyō Daigaku Bungakubu Bijutsushi Kenkyūshitsu $3^{2}$ (March 2016): 100-52; Mochizuki, "Jesuit Visual Culture in a Machine Age," 449-86; Yoriko Kobayashi-Sato and Mia M. Mochizuki, "Perspective and Its Discontents or St. Lucy's Eyes," in Seeing across Cultures in the Early Modern Period, ed. Dana Leibsohn and Jeanette Favrot Peterson (Farnham: Ashgate, 2012), 21-48; Mochizuki, "Sacred Art in an Age of Mechanical Reproduction," 129-44; Mochizuki, "Shock Value: The Jesuit Martyrs of Japan and the Ethics of Sight," in Sensational Religion: Sensory Cultures in Material Practice, ed. Sally M. Promey (New Haven: Yale University Press, 2014), 375-97.

Alison C. Fleming, ed., "Jesuit Visual Culture," Journal of Jesuit Studies, Special Issue, 6, no. 2 (Spring 2019).

46 Michel de Certeau, s.J., "L'óperation historique," in Faire de l'histoire, ed. Jacques Le Goff and Pierre Nora (Paris: Gallimard, 1974), 1:3-41; Pierre Antoine Fabre, "Dossiers bibliographiques: Histoire des arts visuels," Revue de synthèse, 4th series, nos. 2-3 (AprilSeptember 1999): 462-68; Pierre Antoine Fabre and Antonella Romano, "Présentation," Revue de synthèse, 4th series, nos. 2-3 (April-September 1999): 247-6o.

47 Wietse de Boer, "The Early Jesuits and the Catholic Debate about Sacred Images," in de Boer, Enenkel, and Melion, Jesuit Image Theory, 51-73; Ralph Dekoninck, "The Founding of a Jesuit Imagery: Between Theory and Practice, between Rome and Antwerp," in The Acquaviva Project: Claudio Acquaviva's Generalate (1581-1615) and the Emergence of Modern Catholicism, ed. Pierre Antoine Fabre and Flavio Rurale (Chestnut Hill, MA: Institute of Jesuit Sources, 2017), 335-50; Dekoninck, "Invention de l'image de la Compagnie de Jésus entre Rome et Anvers," in Italia Belgica, ed. Nicole Dacos and Cécile Dulière, Institut Historique Belge de Rome Études d'Histoire de l'Art 9 (Turnhout: Brepols, 2005), 163-87; John W. O'Malley, S.J., "Trent, Sacred Images, and Catholics' Senses of the Sensuous," in The Sensuous in the Counter-Reformation Church, ed. Marcia B. Hall and Tracy E. Cooper (Cambridge: Cambridge University Press, 2013), 28-48.

48 Levy, "Early Modern Jesuit Arts and Jesuit Visual Culture," 66-87, esp. 79-81. 
its multi-functionality, and resist the siren call of stylistic interpretation, be it in the form of St. Ignatius as a co-founder of the baroque or the search for a unified theory. The latest review of the study of Jesuit art, by Jeffrey Muller (2017), concluded: "Just as there is no Jesuit style, so there is no separate Jesuit historiography of their art, architecture, and visual communications," in order to draw attention to overlooked early modern Jesuit writings on art. ${ }^{49}$ Jesuits differed from other early modern writers on art, namely as religious invested in the spirituality of images, not only politics and personalities. Yet art historians have too often hesitated to immerse themselves in the mental worlds of Jesuits - their training, their philosophy, and their spirituality—preferring instead the concrete, tangible realia of Jesuit actors and makers, a lacuna Luce Giard has likened to "somebody who wants to learn a foreign language, but has no intention of ever speaking to a native speaker and does not really care for the native speakers." ${ }^{50}$

Art historians need not become historians, but a rudimentary familiarity with the guiding precepts of the order is a precondition for an informed analysis of Jesuit art. ${ }^{51}$ It is perhaps not terribly original to recommend O'Malley's The First Jesuits (1993), but every art historian should read this classic book that remains unrivaled for its introduction to the theory and praxis of the Jesuits, what they did and why they did it, such as how education became the Society's paramount ministry. ${ }^{52}$ The collection of O'Malley's most frequently cited essays in the volume Saints or Devils Incarnate? Studies in Jesuit History (2013) rewards any scholar embarking on new research. ${ }^{53}$ Along with books like The Jesuits and The Jesuits II, a number of online Open Access resources, available to the public without charge, now facilitate the immediate gratification

49 Jeffrey Muller, "Historiography of the Art and Architecture of the Jesuits," in Jesuit Historiography Online, ed. Robert A. Maryks, [2-18, 27]; http://dx.doi.org/10.1163/2468 -7723_jho_SIM_192594 (accessed March 13, 2021).

50 Luce Giard, "Reflections: What Have We Learned? Where Do We Go from Here?," in O'Malley et al., Jesuits, 707-12, here 709-10.

51 For an introduction to art historical methodologies, issues, and vocabulary, including non-verbal forms of communication, like line, color, form, composition, materiality, technique, and function, see Anne D'Alleva, Look! The Fundamentals of Art History, 3rd ed. (Boston: Prentice Hall, 2010); Sylvan Barnet, A Short Guide to Writing about Art (Boston: Pearson Education, 2013); Robert S. Nelson and Richard Schiff, eds., Critical Terms for Art History, 2nd ed. (Chicago: University of Chicago Press, 2003); James Smith Pierce, From Abacus to Zeus: A Handbook of Art History, 7 th ed. (Upper Saddle River: Pearson Prentice Hall, 2004); Steen Eiler Rasmussen, Experiencing Architecture (Cambridge: MIT Press, 1995). 
of those wishing to acquire a 36o-degree view of Jesuit art. A perusal of Robert Maryks's Jesuit Historiography Online (2016-present) delivers in-depth regional and thematic reviews (seventy essays at the time of writing), and his founding of the peer-reviewed Journal of Jesuit Studies in 2014 and Jesuit Studies book series in 2013 established complementary resources to the bastion of Jesuit studies, the Archivum historicum Societatis Iesu. ${ }^{54}$ Thomas Worcester, S.J. has furnished a thorough synopsis of the spirituality, history, and reach of the Society in his edited volume, The Cambridge Companion to the Jesuits (2008), which is deftly paired with John Patrick Donnelly's anthology Jesuit Writings of the Early Modern Period 1540-1640 (2006) for sampling the flavor of early Jesuit writings, from spiritual to ministerial, political to practical concerns. ${ }^{55}$ In 2017, Worcester compiled a reference work, The Cambridge Encyclopedia of the Jesuits, where readers can find an entry on any number of Jesuit-related subjects. ${ }^{5}$ Ines Županov's magisterial The Oxford Handbook of the Jesuits (2019) is a great boon for researchers, consisting of over a thousand pages from forty-one contributing authors. ${ }^{57}$ This book is a mandatory first stop for anyone interested in Jesuit topics, as experts weigh in on what characterized Jesuit incorporation and administration, spirituality and economy, education and politics, global mission, art and science, anti-Jesuitism and restoration, and these thoughtful reflections set a high benchmark for investigations to come.

One of the more striking aspects of this dynamic field is the shift in who is writing its histories. Until fifty years ago, scholarship on the Society of Jesus was dominated by Jesuit authors. Nowadays, O'Malley has estimated that lay academics contribute at least ninety-five percent of historical bibliography, often by non-Catholic scholars, many without any religious affiliation. ${ }^{58}$ Although it was crucial to encourage the multiplicity of outside perspectives, the "désenclavement" trend detected by Giard, some of the most nuanced current writing

54 Archivum historicum Societatis Iesu (Rome: Archivum Romanum Societatis Iesu, 1932present): http://www.sjweb.info/arsi/en/publications/ahsi/ (accessed March 13, 2021); Robert A. Maryks, ed., Journal of Jesuit Studies (Leiden: Brill, 2014-present): https://brill .com/view/journals/jjs/jjs-overview.xml (accessed March 13, 2021); Robert A. Maryks, ed., Jesuit Historiography Online (Leiden: Brill, 2016-present): https://referenceworks.brill online.com/browse/jesuit-historiography-online (accessed March 13, 2021); Robert A. Maryks, ed., Jesuit Studies: Modernity through the Prism of Jesuit History (Leiden: Brill, 2013): https://brill.com/view/serial/JS (accessed March 13, 2021).

John Patrick Donnelly, S.J., ed. and trans., Jesuit Writings of the Early Modern Period 15401640 (Indianapolis: Hackett Publishing Company, 2006); Thomas Worcester, s.J., ed., The Cambridge Companion to the Jesuits (Cambridge: Cambridge University Press, 2008).

$5^{6} \quad$ Worcester, Cambridge Encyclopedia of the Jesuits.

57 Županov, Oxford Handbook of the Jesuits.

$5^{8}$ O'Malley, "Past, Present, and Future of Jesuit Studies," 504, 507-8. 
has stemmed from the recognition of the competing loyalties between being a Jesuit and recounting one's own history, and we are now at a point where it is imperative to make sure the many positions of "insiders' views" are not lost, so a lone voice is not mistaken for a monolithic entirety. ${ }^{59} \mathrm{Jesuit}$ criticism requires the delicate feat of pinpointing a memory of a social body that continues to evolve in time, where the past, especially one complicated by surviving a papal suppression, can be soldered to a living, breathing tradition. ${ }^{60}$ Any account must also take into consideration the election of the first Jesuit pope, Jorge Mario Bergoglio, as Pope Francis I in 2013, introducing a new facet to the complex bond between Jesuits and the papacy, which has acted as both a means to, and a check on, the Jesuit call to the world. ${ }^{61} \mathrm{~A}$ changing academic ecosystem has energized Jesuit studies; that the great world keeps spinning is what lends grist for the sustained progress of scholarship on early modern Jesuit art.

\subsection{Rationale}

The study of Jesuit art has enjoyed a veritable golden age in the past two decades, to the point where scholars are hard pressed to stay abreast of the latest breakthroughs. This volume proceeds from the motivation for the Brill Research Perspectives series: the need for a succinct, accessible, and timely guide to areas of particular interest; it does not purport to be a historical synopsis of Jesuit art, an audit of individual traits, or a status quaestionis review. The goal of this book is to showcase how the changing landscape of specialized studies can prompt new inquiries, but then in a manner pruned of enough discipline-specific language to support interest from scholars outside the discipline. Since Jesuit art has yet to be tied to current discourses in art history, this volume should be read as a virtual seminar, an unconventional critical reflection on promising directions for the research of Jesuit art.

Twelve sections are organized under four main divisions. The first part, "Introduction," has attempted to revise the panorama of Jesuit art by beginning

59 Simon Ditchfield, "Getting beyond 'Jesuit Thinking': The Désenclavement of Jesuit Studies Twenty Years On; Where We Are Now; A Consideration of Ines G. Županov, ed., The Oxford Handbook of the Jesuits (Oxford: Oxford University Press, 2019)," Journal of Jesuit Studies 7, no. 2 (2020): 311-22; Fabre and Romano, "Présentation," 254-57; Giard, "Reflections," 70712, esp. 708.

6o "Restoration," in Županov, Oxford Handbook of the Jesuits, 951-1072, esp. Martín A. Morales, "The Restoration of the Society of Jesus and the Vagaries of Writing," 953-73; Guillermo Wilde, “Jesuit Missions' Past and the Idea of Return: Between History and Memory," 100435; and Benoît Vermander, s.J., "Jesuits in the Twenty-First Century," 1054-72.

61 Vermander, "Jesuits in the Twenty-First Century," 1054-72; Thomas Worcester, S.J., "Jesuit Studies in the Age of a Jesuit Pope," Renaissance Quarterly 69 (2016): 1401-12. 
with an inclusive body of work and an overview of the confluence of historiographical circumstances that eclipsed it until recently. A selection of resources prepared a common ground for conversations among art historian and non-art historian alike.

How did such a diverse art come about? The second part, "Sources," will consider the debate that would not rest, the existence of a distinctive "Jesuit style," but now from a fresh vantage point: it looks to the portable illustrated booksLoyola's Spiritual Exercises, Jerónimo Nadal's (1507-80) Evangelicae historiae imagines (Images of Gospel history), and the Imago primi saeculi Societatis Iesv - that disseminated a more pervasive and flexible corporate identity for the many iterations of Jesuit art than any single style or building. The visual consequences of these well-known books provide the reader with a solid foundation for whichever aspects of Jesuit art he or she wishes to pursue.

The third part, "Contributions," then pivots from past disputes to reflect on the relevance of early modern Jesuit art today by looking at how the Society's experiments in art-making would come to define the modern image. The uniquely worldwide construction of Jesuit art promoted the exploration of objects that were internally networked, technologically defined, and innately subjective.

The fourth part, "In Place of a Conclusion," since this volume is intended to galvanize more research, takes a page from the historian's use of counterfactual history to ponder the intriguing hypothesis: What if there had been no Jesuit art? For it is in the answer to this question, whether we have unwittingly assigned Jesuit art too much credit, that the justification for its future study is cast in sharpest relief.

Two caveats clarify why I have chosen to refrain from the presentation of this material by period or by region. A chronological approach to Jesuit art has established a tripartite format: an early codification of the newly founded order (1540-1622), which ended with the canonization of Saints Ignatius and Xavier; a mature middle phase (1622-64), when expression flourished; and a later commemorative style (1664-1773), initiated under Giovanni Paolo Oliva (160o-81), eleventh superior general of the Society (in office 1664-81), that lasted until the suppression. ${ }^{62}$ The advantage of this arrangement resides in its pragmatic and effective cataloging of the order's artistic output. However, with the growth in objects that constitute Jesuit art, it becomes clear that

62 Gauvin Alexander Bailey, "The Jesuits and Painting in Italy, 1550-169o: The Art of Catholic Reform," in Saints and Sinners: Caravaggio and the Baroque Image, ed. Franco Mormando, exh. cat. (Chestnut Hill, MA: McMullen Museum of Art, Boston College, 1999), 151-78; Evonne Levy, "A Noble Medley and Concert of Materials and Artifice': Jesuit Church Interiors in Rome, 1567-1700," in Saint, Site, and Sacred Strategy: Ignatius, Rome, and Jesuit Urbanism, ed. Thomas M. Lucas, S.J., exh. cat. (Vatican City: Biblioteca Apostolica Vaticana, 1990), 46-61. 
these elements do not necessarily correlate to a timeline, as can be seen in the Society's global production. Moreover, such an organization can inadvertently give the misleading impression of a sequential evolution in Jesuit art, when one of its more thought-provoking legacies lies in how images could function independent of a master narrative.

As far as a topographic method, when the Society's workshops around the world are treated, their production tends to be compartmentalized by region, again helpful for a preliminary classification of the material, if unintentionally reifying the anachronistic national distinctions that have impeded the study of early modern art history. Isolating objects in geographic silos can foster the illusion, for instance, that a work associated with the Jesuits active in Ethiopia had no bearing on the mission to Goa, although this port city was a half-way stop for Jesuits on the Portuguese eastern trade route before doubling back to West Africa or pressing forward into South and East Asia. And too much of a focus on difference can threaten to obscure the representative themes that bound the order and would only become heightened in a post-Tridentine climate. But perhaps the best reason for avoiding such a framework, at this stage, is that it can detract from a signal achievement of the first Jesuits: the vision of an interconnected world, in its manifold forms, as a centerpiece for the Society's identity.

\section{Part 2: Sources}

\subsection{A "Jesuit Style"?}

For Jesuit art, the question of sources has been dominated by the issue of whether a "Jesuit style" exists, with the Church of the Gesù at the core of this argument. Begun in 1568, after the design of the architects Giacomo Barozzi da Vignola (1507-73) and Giacomo della Porta (1532-1602), if largely implemented under Giovanni Tristano (c.1515-75) and Giovanni de Rosis (1538-1610), the Gesù was completed in 1575 and consecrated on November 25, 1584. ${ }^{63}$ Outside, its façade was known for its streamlined, classical symmetries and the memorable inverted scrolls bracing the ends of its upper level, welcomed for its appropriately austere exemplification of the "simple style," reflecting della Porta's design over Vignola's more elaborate plans for a sculpture-packed exterior (fig. 2.1). ${ }^{64}$ Inside, Vignola's plan for the composition of space adopted the

\footnotetext{
63 Nanni di Baccio Bigio (or Giovanni Lippi, c.1507-68) designed a replacement, never realized, for the Church of the Madonna della Strada (1549-50).

64 Clare Robertson, "Gesù, Rome," in Worcester, Cambridge Encyclopedia of the Jesuits, 33537; Robertson, Gran Cardinale, 181-96.
} 


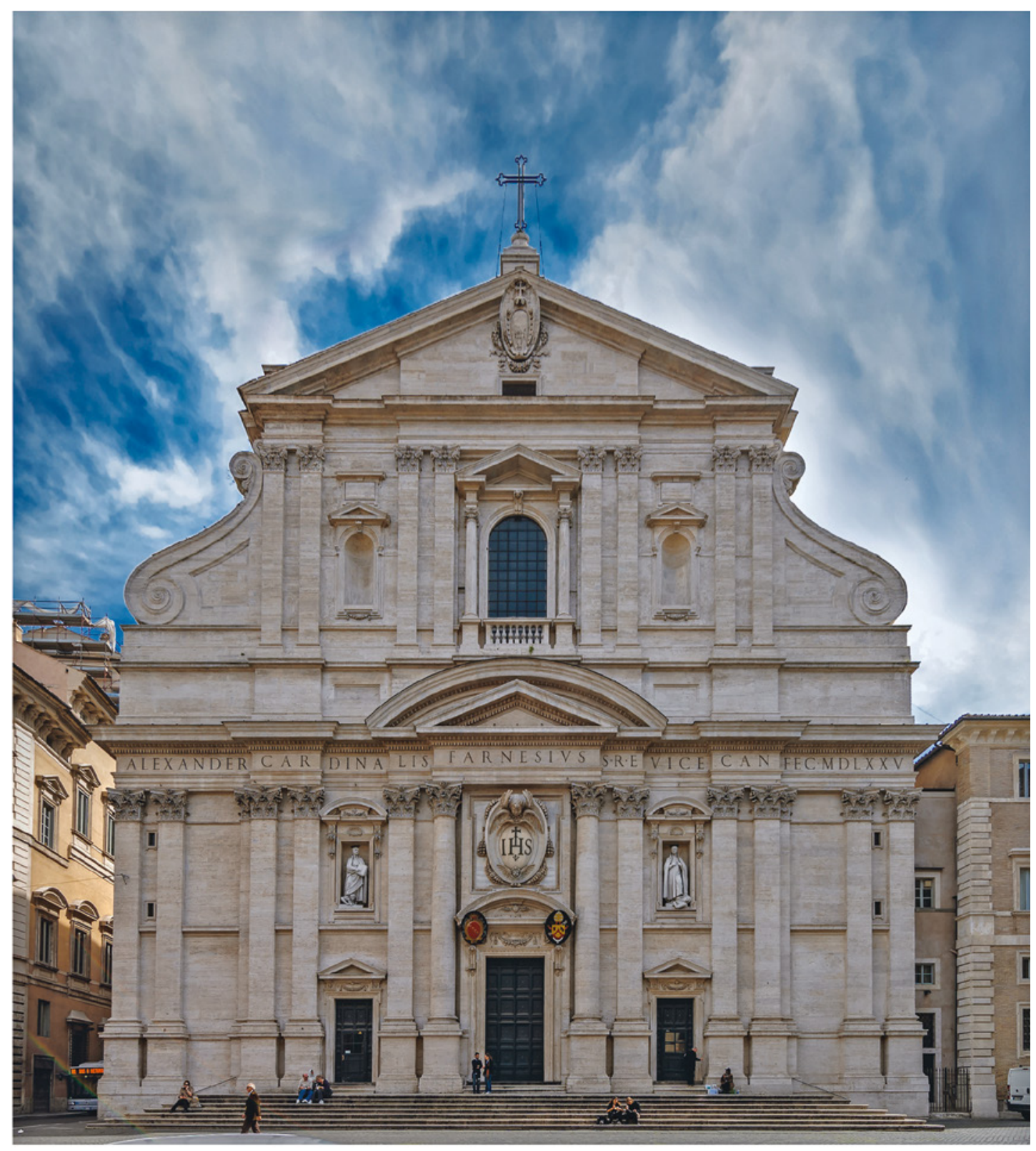

FIgURE 2.1 Giacomo Barozzi da Vignola, Giacomo della Porta, Giovanni Tristano, and Giovanni de Rosis, Church of the Gesù, Exterior, 1568-75, Rome PHOTO: (C) ZENO COLANTONI 


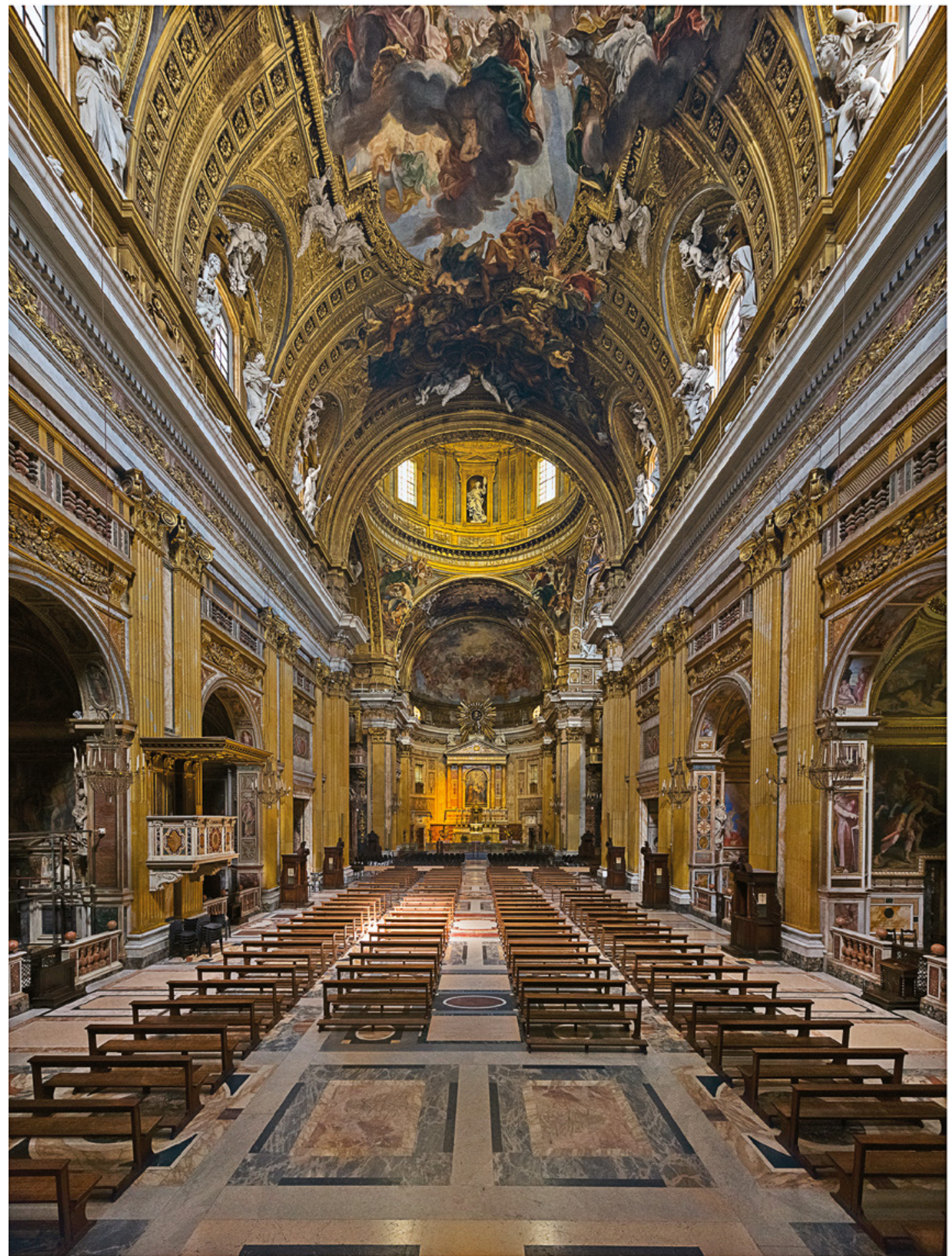

FIgURE 2.2 Giacomo Barozzi da Vignola, Giacomo della Porta, Giovanni Tristano, and Giovanni de Rosis, Church of the Gesù, Interior, 1568-75, Rome

PHOTO: (C) ZENO COLANTONI 
reforms championed by Jesuits in line with Tridentine decrees, such as a wide nave to facilitate sermons, the removal of a choir screen barrier to the high altar, and the inclusion of confessionals (fig. 2.2). ${ }^{65}$ The Gesù became a paradigm for a Catholic Reformation worship experience, its public façade marked the church as "Jesuit" as its private interior affirmed the values the young order espoused. The scale of the Society of Jesus's architectural activity is remarkable by early modern standards: Thomas Lucas, S.J. has estimated that by the time of its suppression in 1773, the order had constructed 160 churches in Italy and 1,200 churches worldwide. ${ }^{66}$ The familial resemblance among Jesuit buildings became known as the "Jesuit style" and stamped an identity, like the Society's Seal or monogram, so that no matter how remote the location, an inhabitant, a visitor, and a trader would know a Jesuit church when he or she saw one. The idea of a "Jesuit style" was born, consistent but adaptable enough to be customized locally, a theory tantalizingly publicized by Carlo Galassi Paluzzi's (1893-1972) Storia segreta dello stile dei gesuiti (The secret history of the Jesuit style [1951]). ${ }^{67}$

65 Rudolf Wittkower, "Problems of the Theme," in Wittkower and Jaffe, Baroque Art, 1-14, here $2-3$.

66 Thomas Lucas, S.J., "Baroque Art and Architecture," in Worcester, Cambridge Encyclopedia of the Jesuits, $80-87$, here 82 .

67 For an introduction to the "Jesuit style" debate, see Gauvin Alexander Bailey, "Le style jésuite n'existe pas: Jesuit Corporate Culture and the Visual Arts," in O'Malley et al., Jesuits, 38-89, esp. 39-44; Denis Cyril Barrett, S.J., "A 'Jesuit Style' in Art?," Studies: An Irish Quarterly Review 45, no. 179 (Autumn 1956): 335-41; Joseph Braun, s.J., Die belgischen Kirchenbauten: Ein Beitrag zur Geschichte des Kampfes zwischen Gotik und Renaissance (Freiburg im Breisgau: Herdersche Verlagshandlung, 1907); https://archive.org/stream/ diebelgischenjesoobrau (accessed March 13, 2021); Braun, Die Kirchenbauten der deutschen Jesuiten (Freiburg im Breisgau: Herdersche Verlagshandlung, 1908-10), 1:v; vol. 1, https://archive.org/details/bub_gb_nhdh9oB_kSsC, vol. 2, https://archive.org/details/die kirchenbauteno2brauuoft (accessed March 13, 2021); Joseph Braun, s.J., "Bauten," in Bernhard Duhr, S.J., Geschichte der Jesuiten in den Ländern deutscher Zunge im XVI. Jahrhundert (Freiburg im Breisgau: Herdersche Verlagshandlung, 1907-28), 1:602-45; Braun, Spaniens alte Jesuitenkirchen: Ein Beitrag zur Geschichte der nachmittelalterlichen kirchlichen Architektur in Spanien (Freiburg im Breisgau: Herdersche Verlagshandlung, 1913); https://archive.org/stream/spaniensaltejesuoobrauuoft (accessed March 13, 2021); Carlo Bricarelli, s.J., "Le chiese degli antichi gesuiti in Germania," La civiltà cattolica 61, no. 4, issue 1449 (1910): 338-43; Yvan Christ, "Le 'style jésuite' n'existe pas," Jardin des arts 86 (1962): 44-49; François de Dainville, s.J., "La légende du style jésuite," Études: Revue fondée en 1856 par des pères de la Compagnie de Jésus 88, no. 287 (October-December 1955): 3-16; https://gallica.bnf.fr/ark:/12148/bpt6k5720089o.r=dainville?rk=21459;2 (accessed March 13, 2021); Engelbert Kirschbaum, s.J., "La Compagnia di Gesù e l'arte," in Il quarto centenario della costituzione della Compagnia di Gesù: Conferenze commemorative tenute 
Contemporary evidence seemed to support the idea of a "Jesuit style." Just two years after Loyola's death, in 1558 , the First General Congregation of the Society issued a ruling (decree 34) on the erection of buildings that was confirmed and organized after the Second General Congregation in 1563 (decree 103). ${ }^{68}$ Guidelines stated that Jesuit edifices should not be overly lavish but rather be built "practical, healthful, and sturdy," "neither sumptuous nor novel" so as to instill the contemplation of poverty ("utilia, sana et fortia [...] in quibus tamen pauperitatis nostrae memores esse videamur. Unde nec sumptuosa sint nec curiousa"). They should hew to the "form and manner of our buildings" ("formam et modum nostrorum aedificiorum"), implying a generally understood Jesuit norm, even if this frequently quoted paradigm referred only to schools and houses, leaving designs for churches unrestricted ("De ecclesiis tamen nihil dictum est."). Concerted efforts to cultivate a degree of regularity, with "une diffusion quasi-universelle" (a quasi-universal diffusion), seem to have proceeded apace until the death of the fourth superior general, Everard Mercurian (151480, in office 1573-80). ${ }^{69}$ Jesuit architects like de Rosis assembled "look-books" filled with a selection of acceptable plans for the Society's new construction

all'Università Cattolica del Sacro Cuore, 2-11 maggio 1941, Pubblicazioni della Università Cattolica del Sacro Cuore 5, Scienze Storiche 19 (Milan: Società Editrice "Vita e Pensiero," 1941), 211-26; Levy, "Early Modern Jesuit Arts and Jesuit Visual Culture," 85-86; Muller, "Historiography of the Art and Architecture of the Jesuits," [1-46, esp. 19]; Carlo Galassi Paluzzi, Storia segreta dello stile dei gesuiti (Rome: Francesco Mondini Editore, 1951); Pirri, Giovanni Tristano e i primordi della architettura gesuitica; Alfred Poncelet, s.J., Histoire de la Compagnie de Jésus dans les anciens Pays-Bas: Part 1 , Histoire générale (Brussels: Lamertin, 1926), 575-83; Beatriz Hernán-Gómez Prieto, "Polémica en torno a los orígenes de la arquitectura de los jesuitas y la posible aceptación de un estilo" (MA thesis, University of Oviedo, 1976); Wittkower, "Problems of the Theme," 1-3.

68 Bailey, "Style jésuite n'existe pas," 64-65; Braun, "Bauten," 1:6o3; Joseph Connors, "Reflections: What Have We Learned? Where Do We Go from Here?," in O'Malley et al., Jesuits, 70o-6, here 700; "General Congregations"; https://jesuitportal.bc.edu/research/ general-congregations/ (accessed March 13, 2021); John W. Padberg, S.J., Martin D. O'Keefe, s.J., and John L. McCarthy, S.J., eds., For Matters of Greater Moment: The First Thirty Jesuit General Congregations; A Brief History and a Translation of the Decrees (St. Louis, MO: Institute of Jesuit Sources, 1994), 98, 129; Pirri, Giovanni Tristano e i primordi della architettura gesuitica, 41, 160, 267, 268; Jean Vallery-Radot, Le recueil des plans d'édifices de la Compagnie de Jésus conservé à la Bibliothèque National de Paris (Rome: Institutum Historicum Societatis Iesu, 196o), 6; Wittkower, "Problems of the Theme," 6, n. 17. Vallery-Radot uses two sets of page numbers in his volume: one with asterisks for his study of the collection and one without asterisks for the inventory of designs.

69 Braun, "Bauten," 1:6o6; Pierre Moisy, Les églises des jésuites de l'ancienne assistance de France, Bibliotheca Instituti Historici Societatis Iesu 12 (Rome: Institutum Historicum 
projects, giving the impression that the Society was trying to consolidate designs around a set of shared architectural principles (fig. 2.3). ${ }^{70}$ Notably, all the church designs on this page feature airy naves and unobstructed paths to the central altar, the choir (and its screen) subsumed into a single loft-like space; only one option had old-fashioned side aisles, albeit still incorporated within a rectangular footprint instead of the conventional Gothic cruciform. ${ }^{71}$ The respected Jesuit artist and architect Giuseppe Valeriano (1542-96) was reported to have begun a treatise on building for the Society around the same time, although its existence has yet to be confirmed. ${ }^{72}$ A "Jesuit style" also appeared to adhere to the spirit of "our way of proceeding" ("noster modus procedendi"), the oft-repeated phrase that Nadal ascribed to St. Ignatius himself for a method of handling matters that could be applied to everything from the spiritual realm to mundane logistics.

Perhaps the most lasting rationale for a "Jesuit style," and of the greatest value from the researcher's standpoint, was the institution of a system for approving Jesuit architectural designs that resulted in the preservation of a rich collection of primary sources presently housed in the Bibliothèque Nationale de France in Paris. ${ }^{73}$ At first, all architectural plans and drawings required the official ratification of the superior general, but the sheer scale of the Jesuit building works soon made this practice unwieldy. ${ }^{74}$ The task of translating constitutional decisions into action, with a coordinated central office for examining projects and carrying out inspections, was consolidated in the new post of the Jesuit consiliarius aedificiorum, the censor general for architectural projects. ${ }^{75}$ The

Societatis Iesu, 1958), 1:49-51; Pirri, Giovanni Tristano e i primordi della architettura gesuitica, 270-71; Wittkower, "Problems of the Theme," 7 .

70 Pirri, Giovanni Tristano e i primordi della architettura gesuitica, 41-42, 161, pl. vi; Wittkower, "Problems of the Theme," 7 .

71 Vallery-Radot, Recueil des plans d'édifices de la Compagnie de Jésus, $50^{*}-60^{*}, 76^{*}-86^{*}$.

72 Pirri, Giovanni Tristano e i primordi della architettura gesuitica, 269, no. 9; Wittkower, "Problems of the Theme," 7.

73 The collection was held in the Roman College until the suppression, when it was purchased by the French ambassador to the Vatican and ultimately given to the Bibliothèque Nationale in Paris in 1798. Bösel, Jesuitenarchitektur in Italien, 1540-1773; Bösel and Karner, Jesuitenarchitektur in Italien, 1540-1773; Vallery-Radot, Recueil des plans d'édifices de la Compagnie de Jésus.

74 Padberg, O'Keefe, and McCarthy, For Matters of Greater Moment, 129; Wittkower, "Problems of the Theme," 7 .

75 Moisy, Églises des jésuites de l'ancienne assistance de France, 1:52; Pirri, Giovanni Tristano e i primordi della archite ttura gesuitica, 40-44; Wittkower, "Problems of the Theme," 7 . 


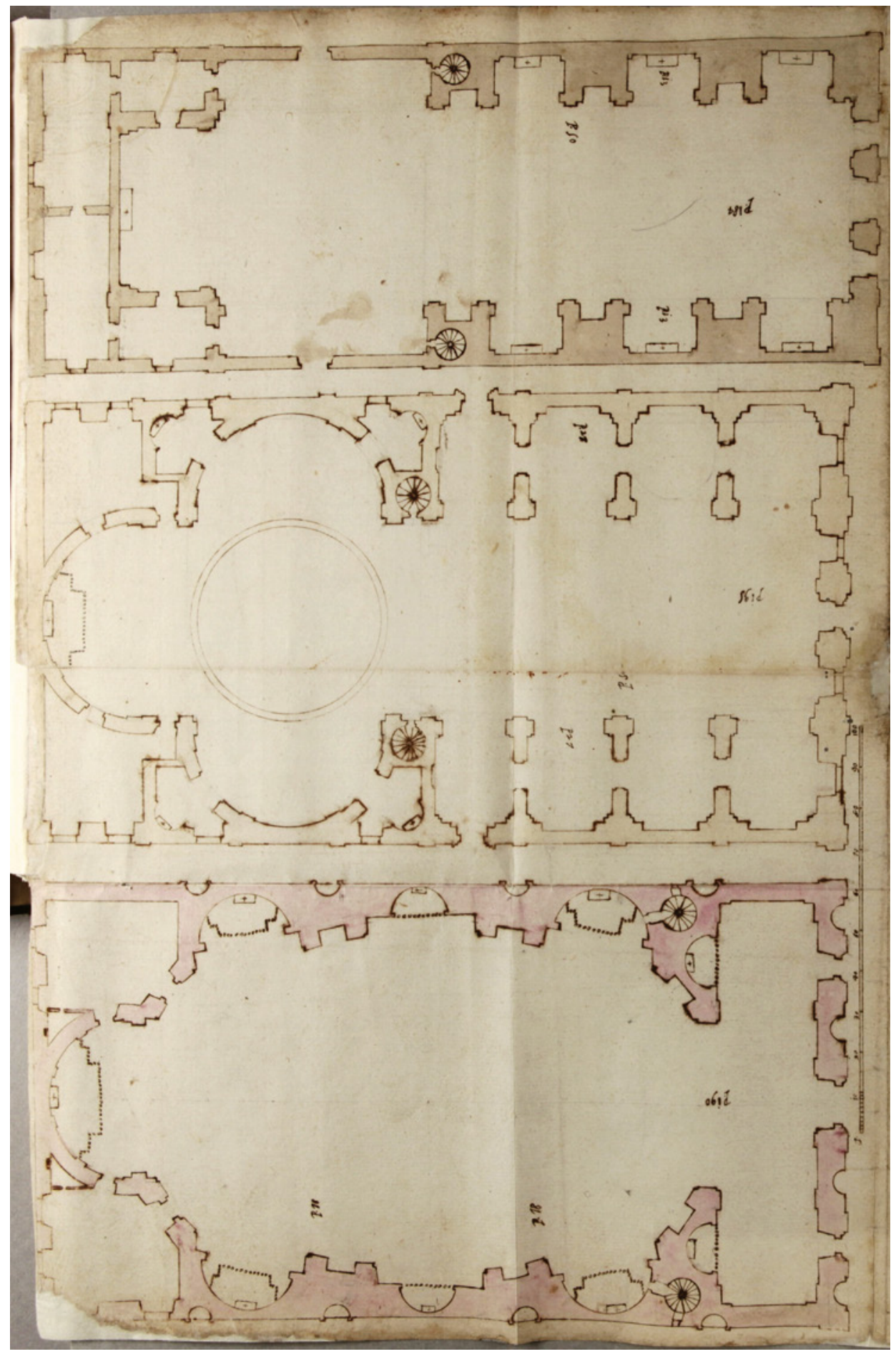

FIG URE 2.3 Giovanni de Rosis, Plans for Jesuit Churches, c.1580, ink on paper, fol. $13^{\mathrm{r}}$ (MS no. Campori 172, inv. no. Gamma.i.1.5o). Modena, Biblioteca Estense Universitaria, Gallerie Estensi

PHOTO: (C) MINISTERO PER I BENI E LE ATTIVITÀ CULTURALI E PER IL TURISMO DELLA REPUBBLICA ITALIANA 


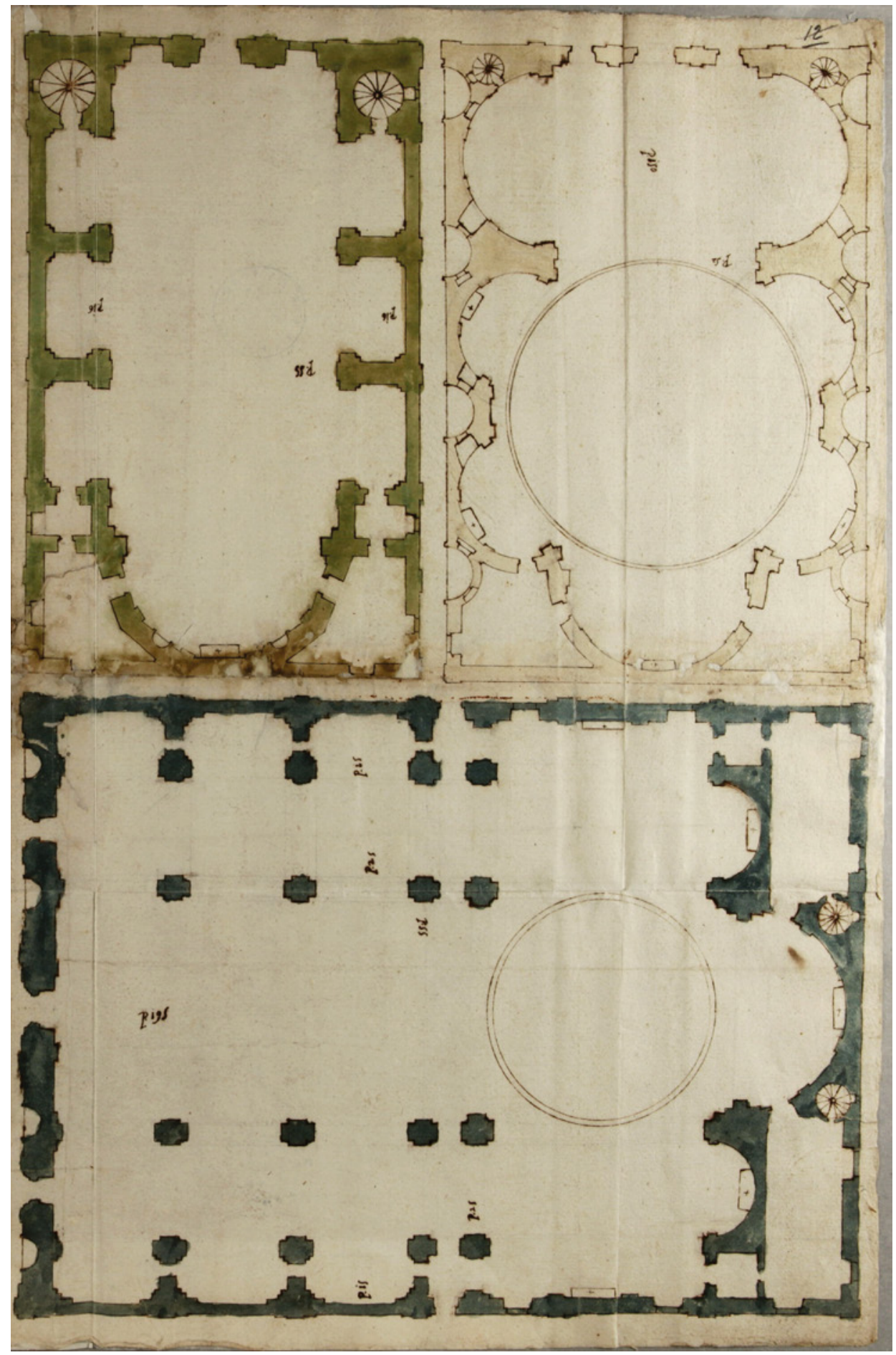




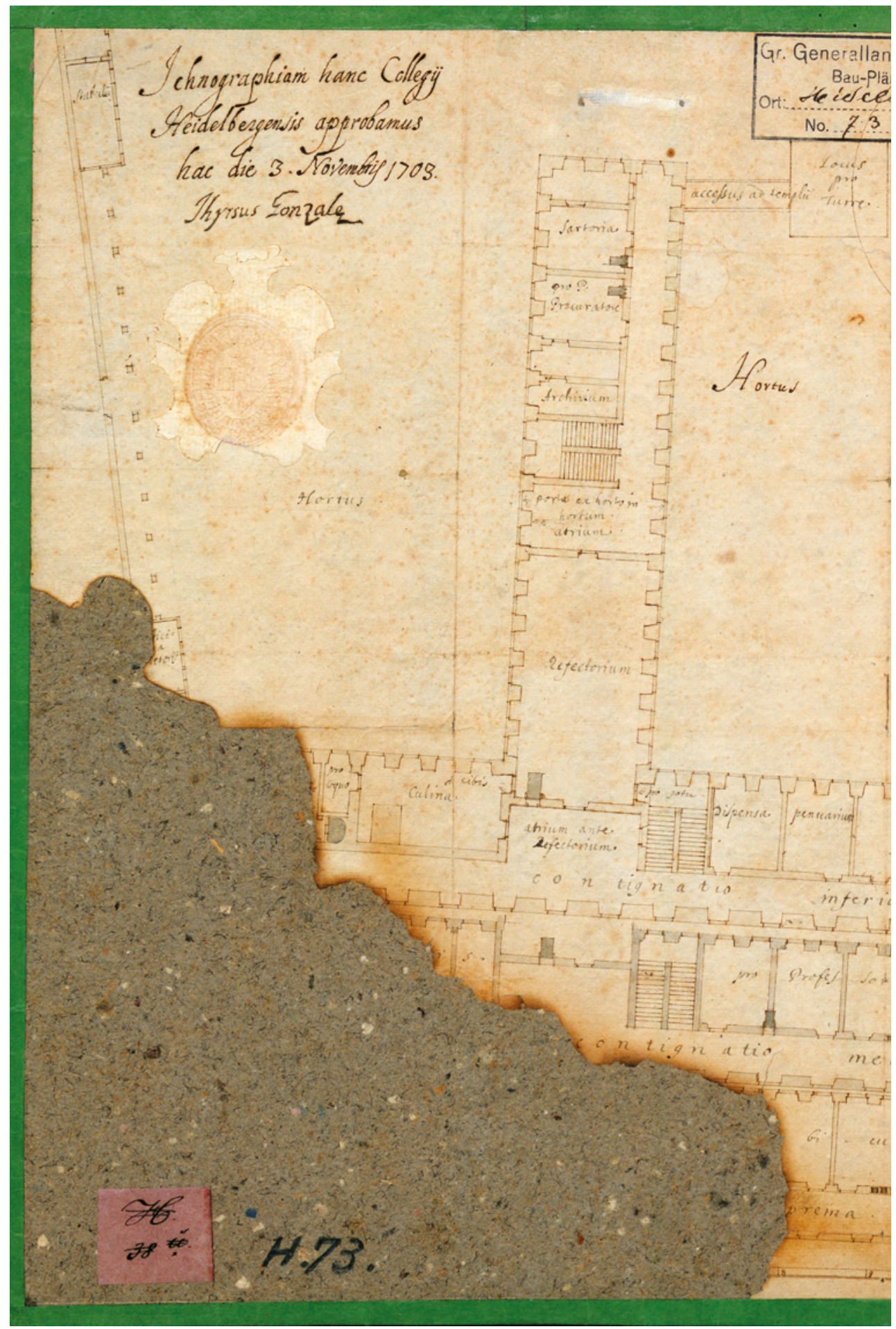

FIGURE 2.4 Plan for the Jesuit College, Heidelberg, c.1703. Karlsruhe, Landesarchiv Baden-Württemberg, Generallandesarchiv Karlsruhe

PHOTO: (C) LANDESARCHIV BADEN-WÜRTTEMBERG, GENERALLANDESARCHIV KARLSRUHE 


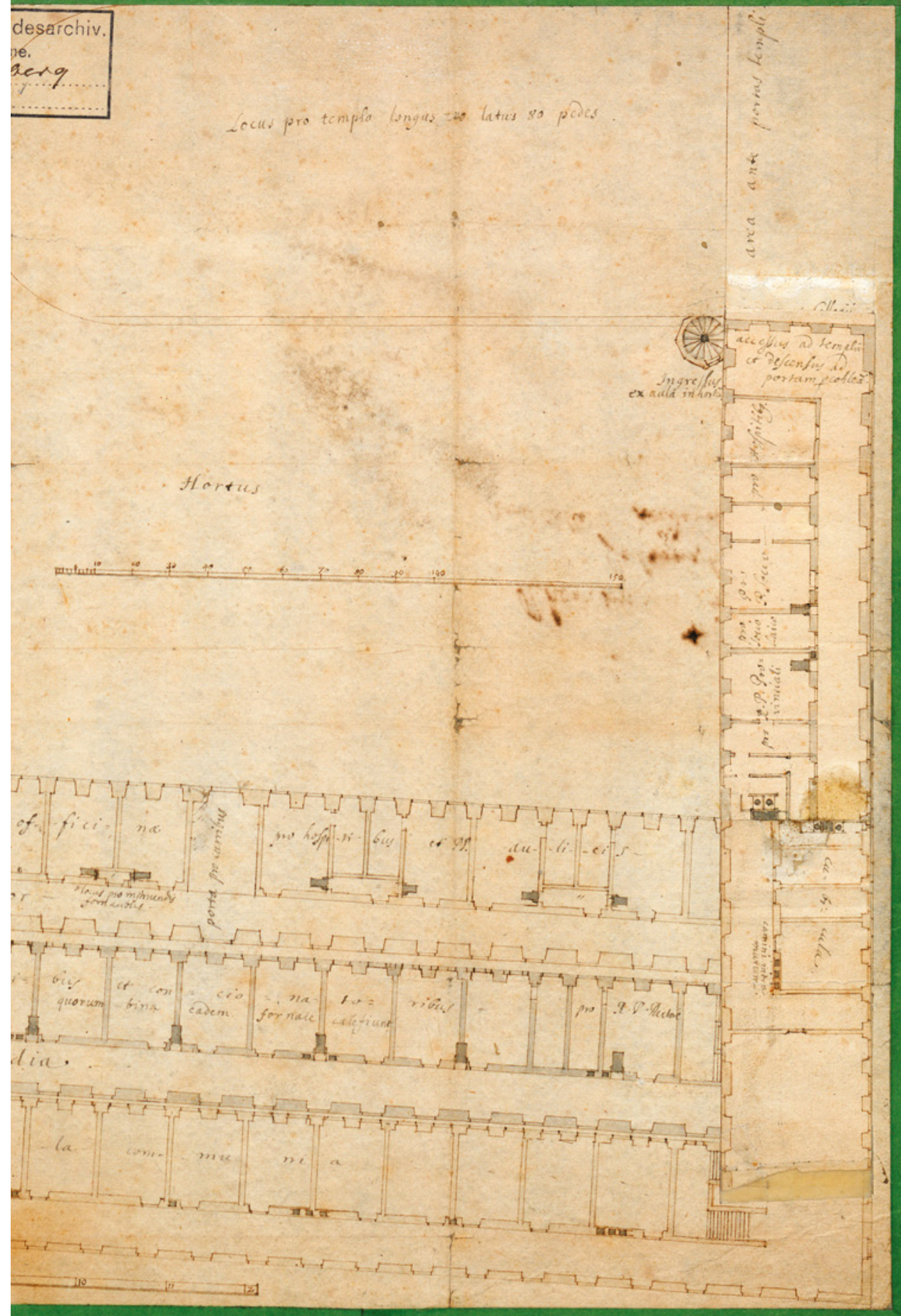


position was first filled by Tristano, which allowed him to keep his hand in the execution of such Jesuit landmarks as the Gesù and the Roman College (Collegio Romano), with institutional continuity provided by the appointment of his students and junior colleagues as his successors. ${ }^{76}$ Jesuits were instructed to submit plans for all buildings, including churches, to the consiliarius aedificiorum or superior general for assessment, after which no further changes could be made. The thirteenth superior general Tirso González de Santalla (16241705, in office 1687-1705) approved the design of the Jesuit College of the Holy Spirit and St. Ignatius in Heidelberg in the top-left corner, "Iconographiam hanc Collegii Heidelbergensis approbamus hac di 3. Novembris 1703. Thyrsus Gonzales" (We approve the plan of Heidelberg College, November 3, 1703. Thyrsus Gonzales) (fig. 2.4). ${ }^{77}$ And inscriptions could also specify enhancements, like that of the provincial of France, Christophe Baltazar (156o-1627), an architect by training who judged the façade of the Jesuit Church of All Saints at Rennes as rather stark and in need of more ornamentation ("Est nimis simplex: addenda aliqua ornamenta.") in March $1624 .{ }^{78}$ But on-site factors, such as the existence of an earlier church or the accommodation of regional preferences, could necessitate substantial variations from proven designs, and by the mid-seventeenth century, the application had become basically pro forma, with architects altering plans after approval. ${ }^{79} \mathrm{~A}$ coherent corporate identity for Jesuit buildings may have been a desired goal, vital for a new order trying to shape a specific profile, but it was amid a proliferation of creative visions, where the works of Jesuit architects were as diverse as those of a Giovanni Battista Fiammeri (c.1530-16o6), a Daniel Seghers (1590-1661), and a Giuseppe Castiglione (1688-1766) among Jesuit artists.

Upon closer inspection, however, cracks begin to appear in the theory of a uniform "Jesuit style." James Ackerman (1919-2016) has shown that many of the spatial reforms for the interior of the Gesù, and therefore generally attributed to Jesuit churches, have been found elsewhere first, sometimes in places

$7^{6}$ The second consiliarius aedificiorum was Tristano's student, Giovanni de Rosis, and the third was Orazio Grassi (1583-1654), whose successors were drawn from the ranks of the mathematics professors at the Roman College. Wittkower, "Problems of the Theme," 7.

77 Peter Anselm Riedl, Die Heidelberger Jesuitenkirche und die Hallenkirchen des 17. und 18. Jahrhunderts in Süddeutschland (Heidelberg: Carl Winter, Universitätsverlag, 1956), 35, pl. 6A; Vallery-Radot, Recueil des plans d'édifices de la Compagnie de Jésus, $21^{*}-23^{*}$; Wittkower, "Problems of the Theme," 6.

78 Moisy, Églises des jésuites de l'ancienne assistance de France, 1:268-70; Muller, "Historiography of the Art and Architecture of the Jesuits," [9-12]; Vallery-Radot, Recueil des plans d'édifices de la Compagnie de Jésus, 170-72, no. 583 .

Wittkower, "Problems of the Theme," 6-7. 
without any particular Jesuit connection (fig. 2.2). ${ }^{80}$ Though not widely mentioned beyond the Portuguese-language bibliography, the auditorium-style nave and elimination of the choir, not to mention the estilo chão, or "plain style," can be found in earlier examples than the Roman Gesù, as in the Lisbon Church of São Roque, the Society's home church in Portugal, built under the direction of the court architects Afonso Álvares (d. c.1580), Baltasar Álvares (156o-1630), and Filippo Terzi (or Felipe Terzio, 1520-97) from 1565 to 1609 (figs. 2.5-2.6). ${ }^{14}$ Clare Robertson has detailed how the third superior general, Borja, lost the battle for modesty in interior decoration to the Gesù's patron, Cardinal Alessandro Farnese (1520-89, in office 1534-89). ${ }^{15}$ Farnese's taste for lavish materials meant that the interior was decked with marble, gilt, and vibrantly hued frescoes, and where Borja had sought a humble, flat roof, minimally decorated, to improve acoustics, with Tristano as the architect of record, Farnese insisted on an elegant barrel vault for the nave under his architect of choice, Vignola. Conflicts like this expose the strain between what the eleventh superior general, Oliva, would later advocate as the discretion of art for edification, intended to short-circuit admiration, and the full-throated Roman baroque that would be propagated under his supervision during the third quarter of the seventeenth century. ${ }^{16}$ Francis Haskell (1928-200o) has underscored the contrast between what was said and what was done, by both patron and incumbent superior general, especially since the illusionistic period of Jesuit art, so closely associated with a "Jesuit style," did not actually begin until over a century after the Society's founding. ${ }^{17}$ The Gesù functioned less as a fixed icon than a stage where the tensions between ideal and reality that would continue to hound Jesuit architecture-be it in terms of restraint versus exuberance,

8o Ackerman, "Gesù in the Light of Contemporary Church Design," 15-28.

14 The Lisbon Church of São Roque would also become the source for many of the order's churches in cities along the Portuguese eastern trade route, like the Sé Cathedral of Santa Catarina in Old Goa, the seat of the patriarch of the East Indies, whose existing building was begun in 1562, completed in 1619, and consecrated in 1640. George Kubler, Portuguese Plain Architecture: Between Spices and Diamonds, 1521-1706 (Middletown, CT: Wesleyan University Press, 1972), 56-75, esp. 61-63; Clare Robertson, "Gaulli, Giovanni Battista (Baciccio)," in Worcester, Cambridge Encyclopedia of the Jesuits, 323-25.

15 Anna C. Knaap, "Art Patronage," in Worcester, Cambridge Encyclopedia of the Jesuits, 54-6o; Robertson, "Two Farnese Cardinals and the Question of Jesuit Taste," 134-47.

16 A letter by Superior General Oliva (July 14, 1668) ends with the desire for art "ut sit ad aedificationem, non vero ad pompam et admirationem." Vallery-Radot, Recueil des plans d'édifices de la Compagnie de Jésus, $14{ }^{*}-15$; Wittkower, "Problems of the Theme," 13.

17 Francis Haskell, "The Role of Patrons: Baroque Style Changes," in Wittkower and Jaffe, Baroque Art, 51-62. 
classicizing versus novel decoration, or institutional coverage versus individual expression-dramatically unfolded.

In fact, long before Galassi Paluzzi's popularization of the "Jesuit style," scholars had definitively disproven it. At the turn of the twentieth century, the notion of a "Jesuit style" was first questioned by Louis Serbat (1875-1953) in 1902-3 and then roundly denounced by Joseph Braun, S.J. (1857-1947) in 1907-12, who categorically stated it was "in Wirklichkeit ein bloßes Phantom" (in reality a mere phantom), that no homogenous style imposed by Rome had ever existed, and most damningly of all: "The word 'Jesuit style' is a name without content, a word without meaning. May it soon disappear from the histories of art and encyclopedias. There is no justification for its existence."18 Braun determined that approval of the plans of Jesuit buildings depended more on functional principles than on any decorative or stylistic qualities, as befits an order committed to the reform of worship. ${ }^{86}$ Notwithstanding the fact that the early modern notion of a copy was bound by less stringent constraints than today, extant churches are striking for having little in common with the Gesù beyond the size and division of space. ${ }^{87}$ Further, church design was often shaped by local circumstance, like the desire to evoke a Byzantine church, reminiscent of the Basilica of Constantine in Rome, for the Munich Jesuit Church of St. Michael, 1583-97, or the need to build on Protestant plans in the Court Church of Our Lady at Neuburg an der Donau, 1607-18, after the young Catholic count palatine of Neuberg, Wolfgang Wilhelm (1578-1653, r.1614-53), succeeded his resolutely Lutheran father, Philipp Ludwig (1547-1614, r.1569-1614) and gave

18 "Das Wort Jesuitenstil ist eine Name ohne Inhalt, ein Wort ohne Sinn. Möge es bald aus den Kunstgeschichten und Enzyklopädien verschwinden. Es ist ohne alle Existenzberechtigung." Sibylle Appuhn-Radtke, "Ordensapologetik als Movens positivistischer Erkenntnis: Joseph Braun, s.J. und die Barockforschung," Archivum historicum Societatis Iesu 79 (2010): 299-320; Braun, Belgischen Kirchenbauten; Braun, Kirchenbauten der deutschen Jesuiten, 1:v, 26o; Braun, "Bauten," 1:6o2-45; Braun, Spaniens alte Jesuitenkirchen; Muller, "Historiography of the Art and Architecture of the Jesuits," [18-20, 40], n. 89; Louis Serbat, "L'architecture gothique des jésuites au XVII ème siècle," Bulletin monumental 66 (1902): 315-70; 67 (1903): 84-134; Wittkower, "Problems of the Theme," 1-3.

86 Braun, Belgischen Kirchenbauten; Braun, Kirchenbauten der deutschen Jesuiten; Braun, Spaniens alte Jesuitenkirchen; de Dainville, "Légende du style jésuite," 3-16; Moisy, Églises des jésuites de l'ancienne assistance de France, 1:61-87; Pierre Moisy, "Martellange, Derand et le conflit du baroque," Bulletin monumental 110, no. 3 (1952): 237-61; Moisy, "Le recueil des plans jésuites de Quimper: Nouvelle étude," Bulletin de la Société de l'Histoire de l'Art Français (1950): 70-84; Pecchiai, Gesù di Roma; Pirri, Giovanni Tristano e i primordi della architettura gesuitica; Serbat, "Architecture gothique des jésuites au XVII ème siècle"; Vallery-Radot, Recueil des plans d'édifices de la Compagnie de Jésus; Wittkower, "Problems of the Theme," 3, 6-7.

87 Bailey, "Style jésuite n'existe pas," 45, 47-63; de Dainville, "Légende du style jésuite," 7. 


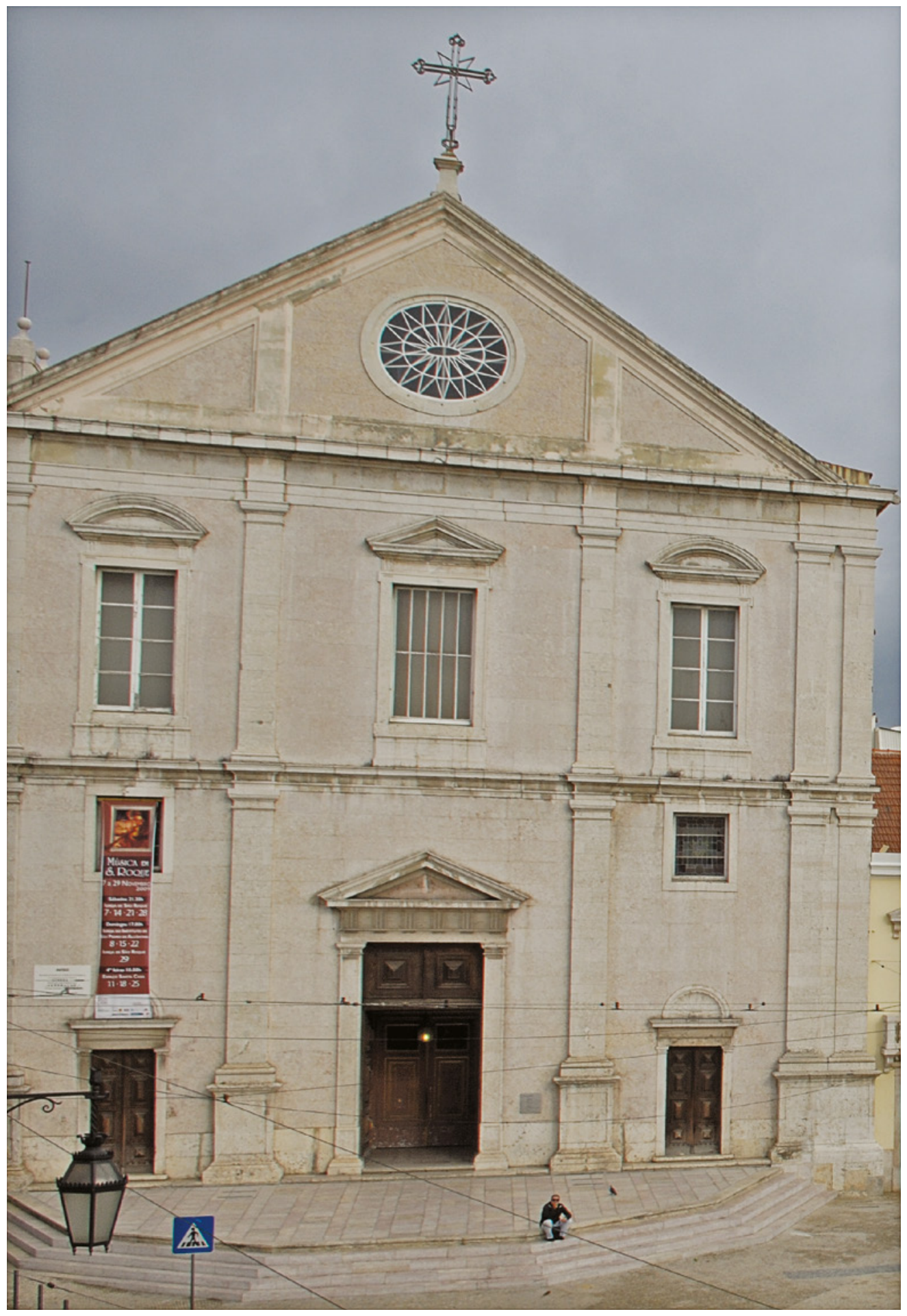

FIGURE 2.5 Afonso Álvares, Baltasar Álvares, and Filippo Terzi, Church of São Roque, Exterior, 1565-16o9, Lisbon

(C) SANTA CASA DA MISERICÓRDIA DE LISBOA. PHOTO: CINTRA \& CASTRO CALDAS 


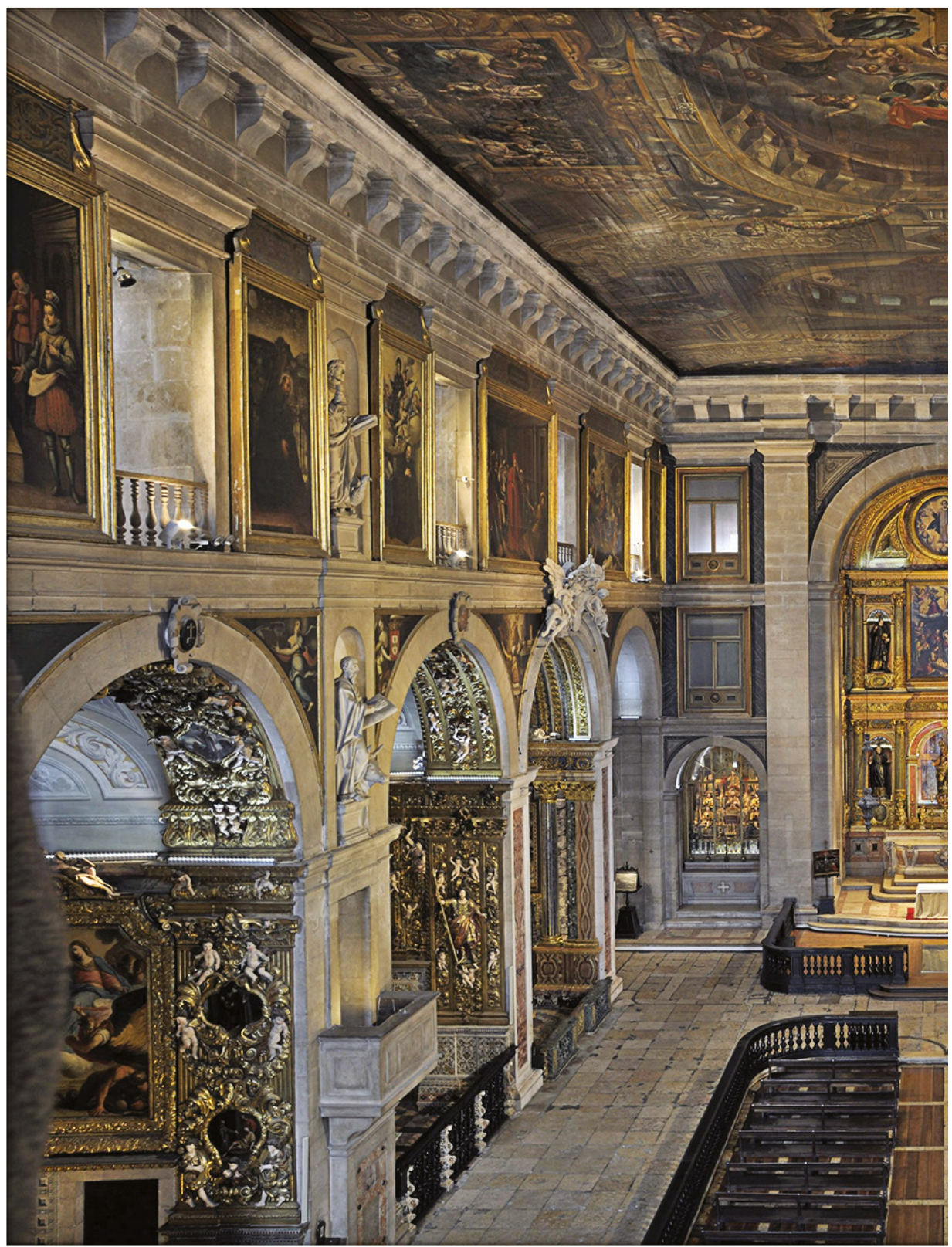

FIGURE 2.6 Afonso Álvares, Baltasar Álvares, and Filippo Terzi, Church of São Roque, Interior, 1565-16o9, Lisbon

(C) SANTA CASA DA MISERICÓRDIA DE LISBOA. PHOTO: NÚCLEO DE AUDIOVISUAIS E MULTIMÉDiA 


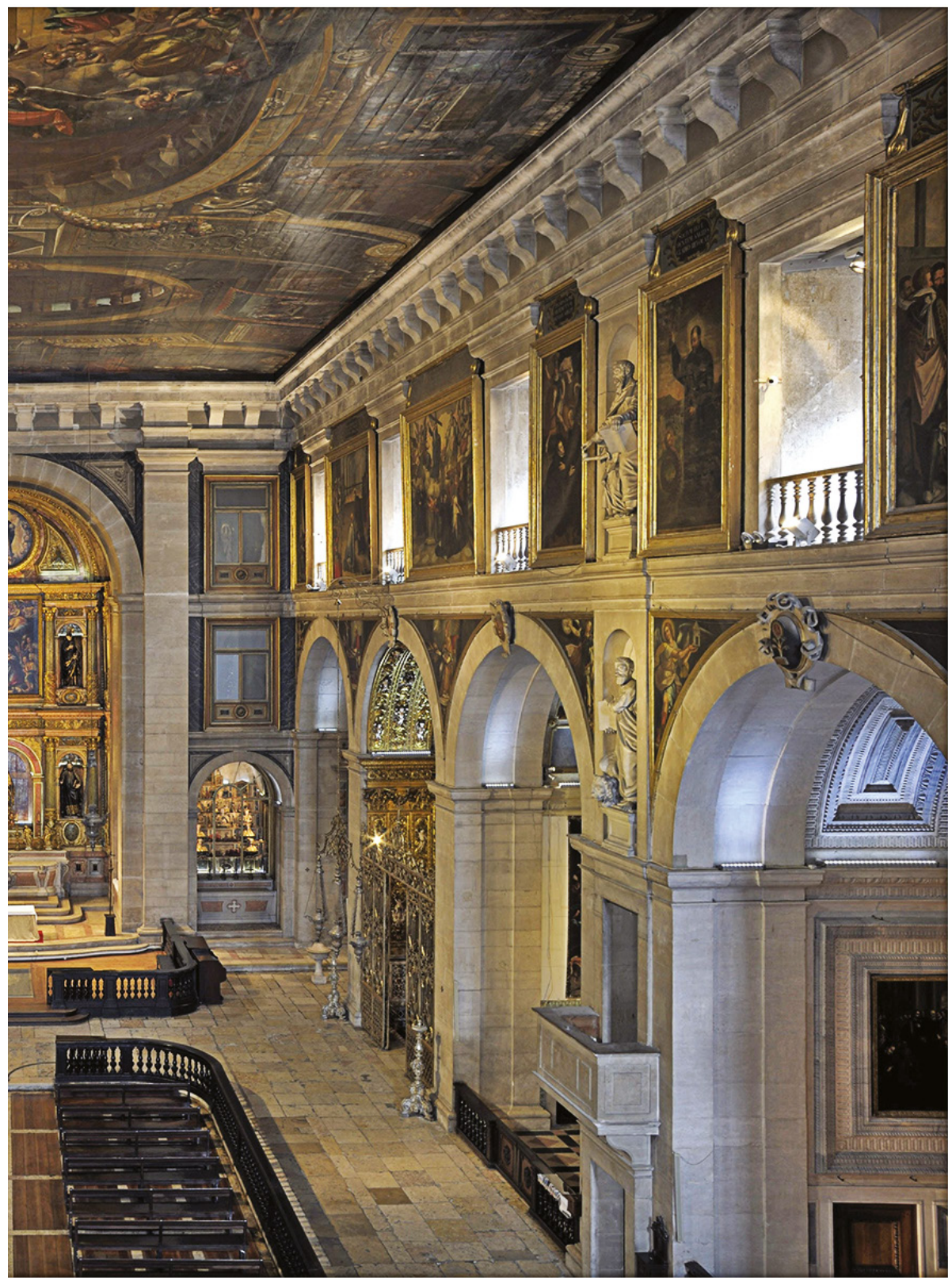


the Court Church to the Jesuits. ${ }^{88}$ Indeed, a keystone in Braun's demolition of the "Jesuit style" was his argument that far from rejecting the streamlined simplicity of the Protestant churches of Northern Europe, the earliest Jesuits built most of their churches in that style through the seventeenth century, and classicizing or Italian elements were balanced by the use of a vernacular iteration of the Renaissance or baroque. ${ }^{89}$ This was a model that would become especially noticeable when applied in the world at large, leading to analysis, for example, of what José Pereira has called the "Indian Baroque" and Maria Cristina Osswald the "modo Goano" (Goan mode). ${ }^{90}$ Confronted with such realities, the enforcement of any one stylistic vocabulary was never a viable option for early modern Jesuit art.

Following in the footsteps of Braun's return to the original ground plans and correspondence of early Jesuit architects, by the 195os, scholars like Pirri, Pecchiai, Pierre Moisy (1912-75), and Jean Vallery-Radot (189o-1971) returned to the archives to show that the Jesuit "way of proceeding" related more to technical issues, like size, location of sacristies and vestries, economy, and speed of execution. ${ }^{91}$ The "Jesuit style" was at least in equal parts practice and theory, and noster modus procedendi should more aptly be termed "not a product, but a process." ${ }^{92}$ Wittkower concluded that a loosely woven Jesuit strategy for what could designate "our buildings" only meant that general formulae were supplemented by the control vested in the consiliarius aedificiorum and the stylistic conformity generated by the practice of sending Jesuit artists and architects (usually Italian) to complete a project. ${ }^{93}$ More recently, Richard Bösel's return to the Italian architectural plans from the Bibliothèque Nationale has led him to emphasize how much more inventive Jesuit buildings were than has

88 Braun, Kirchenbauten der deutschen Jesuiten, 2:49-86, 180-99; Smith, Sensuous Worship, 56-101, 118-19, 143-56; Wittkower, "Problems of the Theme," $3-5$.

89 Braun, Belgischen Kirchenbauten, 1-3; Muller, "Historiography of the Art and Architecture of the Jesuits," [18].

90 Gomes, Whitewash, Red Stone; Osswald, Written in Stone; Pereira, Architecture of Portuguese India; Pereira, Churches of Goa.

91 De Dainville, "Légende du style jésuite," 3-16; Moisy, Églises des jésuites de l'ancienne assistance de France, 1:305-29; Pecchiai, Gesù di Roma; Pietro Pirri, s.J., "L'architetto Bartolomeo Ammannati e i Gesuiti," Archivum historicum Societatis Iesu 12 (1943): 5-57; Pirri, Giovanni Tristano e i primordi della architettura gesuitica; Pirri, Giuseppe Valeriano S.I.; Pirri, "Intagliatori gesuiti italiani dei secoli XVI e XVII," 3-59; Pietro Pirri, S.J., and Pietro di Rosa, s.J., "Il P. Giovanni de Rosis (1538-1610) e la sviluppo dell'edilizia gesuitica," Archivum historicum Societatis Iesu 44 (1975): 3-104; ValleryRadot, Recueil des plans d'édifices de la Compagnie de Jésus, $60^{*}-75^{*}$.

92 Bailey, "Style jésuite n'existe pas," 46, 72-73.

93 Wittkower, "Problems of the Theme," 8-9. 
previously been appreciated, where the Society's building policy should be viewed as a "Ratio aedificiorum," a "Plan of Buildings" reliant on the review, coordination, and archiving of all the Jesuit architectural projects worldwide, comparable to the Ratio studiorum (Plan of studies, 1599) that coordinated a Jesuit system of advanced education while still encouraging innovation. ${ }^{94}$ Fabre has declared that Jesuit art should not be appraised as a "repertoire and a lineage of forms and figures, but as the ensemble of visual manifestations with which the Society of Jesus - which had great power worldwide in the field of cultural representation-surrounded its activities, properly apostolic or pedagogical, civic, etc." ${ }^{15}$ And Dekoninck has stated that rather than tracing the origins of a "Jesuit style," the aim of interpretation should serve the compilation of several "systems of representation governing the production and reception of images," one that was formed and disseminated considerably, but not exclusively, by the Society as agent in a thoroughly modern reshuffling of the rapport between human being and object. ${ }^{96}$

A peculiarity of this bibliography is that although the notion of a "Jesuit style" has been firmly rejected by most scholars for over a century, the topic nevertheless persists in the literature, passed down from one study to the next, in Braun's words, like "congenital defects" ("Erbfehlern"). ${ }^{97}$ By itself, the twentiethcentury historiography of a "Jesuit style" as a neutral and descriptive tool for classification - where a body of objects was identified as "Jesuit," in opposition to other groups, such as religious orders (e.g., Dominicans, Franciscans,

94 Bailey, "Style jésuite n'existe pas," 64; Richard Bösel, "Grundsatzfragen und Fallstudien zur Jesuitischen Bautypologie," in Die Jesuiten in Wien: Zur Kunst- und Kulturgeschichte der Österreichischen Ordensprovinz der Gesellschaft Jesu im 17. und 18. Jahrhunderts, ed. Werner Telesko and Herbert Karner (Vienna: Österreichisches Akademie der Wissenschaften, 2003), 193-209; Bösel, Jesuitenarchitektur in Italien, 1540-1773; Richard Bösel, "La ratio aedificiorum di un'istituzione globale tra autorità centrale e infinità del territorio," in Álvaro Zamora, Ibáñez Fernández, and Criado Mainar, La arquitectura jesuítica, 39-69; Bösel, "Typus und Tradition in der Baukultur gegenreformatorischen Orden," Römische historische Mitteilungen 31 (1989): 239-53; Bösel and Karner, Jesuitenarchitektur in Italien, 1540-1773; Levy, "Early Modern Jesuit Arts and Jesuit Visual Culture," 67; László Lukács, S.J., ed., Ratio atque institutio studiorum Societatis Iesu (1586, 1591, 1599) (Rome: Institutum Historicum Societatis Iesu, 1986).

95 Dekoninck, "Founding of a Jesuit Imagery," 335; Fabre, "Dossiers bibliographiques," 462; Muller, "Historiography of the Art and Architecture of the Jesuits," [22].

96 Dekoninck, "Founding of a Jesuit Imagery," 337.

97 Appuhn-Radtke, "Ordensapologetik als Movens positivistischer Erkenntnis," 299-320; Isabella Balestreri, "L'architettura negli scritti della Compagnia di Gesù," in Patetta and Della Torre, Larchitettura della Compagnia di Gesù in Italia, XVI-XVIII secolo, 19-26; Braun, Kirchenbauten der deutschen Jesuiten, 1:vii; Muller, "Historiography of the Art and Architecture of the Jesuits," [19]; O’Malley, First Jesuits, 8. 
Theatines, Oratorians) or diocesan clergy-would hardly seem to justify such attention; most attempts to catalog works of art have not elicited such a reaction..$^{98}$ But a more complicated story emerges from the term's etymology, when the nineteenth-century reception of Jesuit art laid the battle lines of the deeply contested "baroque." After the renowned antiquarian Jacob Burckhardt (1818-97) was confronted with Jesuit churches as minimalist as their whitewashed Protestant counterparts during his tour of Italy, he substituted the words "baroque" and "Counter-Reformation" for the earlier "Jesuitenstil" in his guidebook to the art of the region, the Cicerone $(1855) \cdot{ }^{99}$ This was a notion of a "Jesuit style" that bore little relation to a set of formal qualities intrinsic to the order, since Burckhardt admitted that Jesuit buildings were consistent with the architecture of their time, could not be uniformly attributed to Jesuit architects, and therefore could not constitute a concerted style. Contrary to twentiethcentury research into contemporaneous early modern sources to retrieve the intentions of those involved in its original design, Burckhardt's description of a Jesuitenstil was pejorative, pervasive, and frankly driven by regional partisan passions of the day-Levy has linked his usage to a conservative cantonal nationalism inflected by Swiss Reformed Protestantism, a "Kantönligeist" —as demonstrated in an article for the Basler Zeitung (July 28, 1844):

The Jesuits are as insincere in their architecture as they were in every other aspect of the spiritual life of the people; they only wanted it to be imposing. [...] From the middle of the seventeenth century, they reached the apex of ecclesiastical architecture and made the degenerate Italian style entirely their own. [...] The grand pomp—and inner poverty—of their ecclesiastical style swept all contemporary Catholic architecture along with it, and this, following in the path of the Jesuits, sacrificed each

98 Bailey, "Style jésuite n'existe pas," 42; Alain Tapié, "Baroque, vision jésuite," and "La rhétorique des flux et de la pose dans la peinture religieuse du XVII e siècle: la différence jésuite," in Tapié, Baroque, vision jésuite, 6-8, 44-59; Walther Weibel, Jesuitismus und Barockskulptur in Rom (Strassburg: Heitz \& Mündel, 1909), 47-49.

99 Jacob Burckhardt, Briefe, ed. Max Burckhardt (Basel: Benno Schwabe, 1949-1966), 9:185; Burckhardt, De Cicerone (Basel: Schweighauser'sche Verlagsbuchhandlung, 1855), 368; Burckhardt, De Cicerone, ed. Heinrich Wölfflin, Gesamtausgabe 3 and 4 (Stuttgart: Deutsche Verlags-Anstalt, 1933); Alexander Dru, ed., The Letters of Jacob Burckhardt (New York: Pantheon, 1955), 216; Evonne Levy, Baroque and the Political Language of Formalism (1845-1945): Burckhardt, Wölfflin, Gurlitt, Brinckmann, Sedlmayr (Basel: Schwabe Verlag, 2015), 58-65, 77-78. As late as 1921, Werner Weisbach (1873-1953) would attribute the tone of Catholic baroque art to St. Ignatius of Loyola. John W. O'Malley, s.J., "The Historiography of the Society of Jesus: Where Does It Stand Today?," in O'Malley et al., Jesuits, 3-37, here 21; Werner Weisbach, Der Barock als Kunst der Gegenreformation (Berlin: P. Cassirer, 1921), $12-15$. 
and every last thing for the sake of raw effect. [...] However, their time has passed; art will no longer allow them to impose their will on it. ${ }^{100}$

Nor was this simply a Protestant tactic; Jesuits themselves were not immune to indulging in the politics of taste, as suggested by the commendation of Galassi Paluzzi's exposition of the "Jesuit style" by Pietro Tacchi Venturi, s.J. (1861-1956), the controversial figure dubbed "Mussolini's Jesuit" for his work as go-between with the Vatican. ${ }^{101}$ The traces of a sectarian "Jesuit style," entrenched in competing strategies of ethics and governance, afforded a proxy for the culture wars of modern life and imbued the stylistic profile of a historical religious order with an evergreen relevance for baroque specialist and nonart historian alike.

But if there is no "Jesuit style" per se, and architectural monuments only functioned as limited models, what remains as formative sources for Jesuit art? Architecture, nevertheless, stands as an apposite point of departure, because scholars have observed that early Jesuit churches often incorporated quotations from early modern illustrated architectural treatises, like those

100 In his use of the term "Jesuitenstil," Burckhardt was very likely influenced by two projects: his revision of the second edition of Handbuch der Kunstgeschichte (1848) for his professor, Franz Kugler (1808-58), where "Jesuitenstil" was included as one of the new designations for post-medieval architecture; and the translation of Jules Gailhabaud's (1810-88) Monuments anciens et modernes into German at Kugler's invitation, which he was already at work on in November 1842, a decade before the book appeared in German (although all four volumes carry the date 1852 , the German translation began to appear in 1844). Jacob Burckhardt, "Jesuitenstil," Allgemeine deutsche Real-Encyklopädie für die gebildeten Stände: Conversations-Lexikon, 9th ed. (Leipzig: Brockhaus, 1845), 7:657-58; Emil Dürr, Jacob Burckhardt als politischer Publizist, ed. Werner Kaegi (Zurich: Fretz \& Wasmuth, 1937), 50-53; Jules Gailhabaud, Monuments anciens et modernes: Collection formant une histoire de l'architecture des differents peuples à toutes les époques, 4 vols. (Paris: F. Didot, 1846-5o); Gailhabaud, Denkmäler der Baukunst, ed. Ludwig Lohde, 4 vols. (Hamburg: J.A. Meissner, 1852); Lionel Gossman, Basel in the Age of Burckhardt: A Study in Unseasonable Ideas (Chicago: University of Chicago Press, 200o); John R. Hinde, Jacob Burckhardt and the Crisis of Modernity (Montreal: McGill-Queen's University Press, 2000), 94, 102-9; Werner Kaegi, Jacob Burckhardt: Eine Biographie (Basel: Benno Schwabe, 19471977), 1:409-27, 2:224; Levy, Baroque and the Political Language of Formalism, 34-94, esp. 36-54; Muller, "Historiography of the Art and Architecture of the Jesuits," [14-18]; Richard Sigurdson, Burckhardt's Social and Political Thought (Toronto: University of Toronto Press, 2004), 28.

101 Donatello Aramini, “'Caesar's Rome' and 'Christian Rome': The Institute of Roman Studies between the Fascist Regime and the Vatican," in Catholicism and Fascism in Europe 19181945, ed. Jan Nelis, Anne Morelli, and Danny Praet (Hildesheim: Georg Olms Verlag, 2015), 255-76; David I. Kertzer, The Pope and Mussolini: The Secret History of Pius XI and the Rise of Fascism in Europe (New York: Random House, 2014), 88-94; Muller, "Historiography of the Art and Architecture of the Jesuits," [20]; Pietro Tacchi Venturi, S.J., "Commento introduttivo," in Galassi Paluzzi, Storia segreta dello stile dei gesuiti, 5-6. 
circulating by Vitruvius ( $c .8 \mathrm{O} / 7 \mathrm{O}$ BCE-after $c .15 \mathrm{BCE})$, Leon Battista Alberti (1404-72), Sebastiano Serlio (1475-c.1554), Andrea Palladio (1508-80), and Vincenzo Scamozzi (1548-1616). These books were also known to be present in Jesuit libraries in Asia and the Americas, their ideas spread afield by Jesuit architects, who had themselves been thoroughly versed in these vocabularies, as when Pozzo instituted a workshop for architecture, painting, and copper engraving at the Roman College in $1681{ }^{102}$ Books prefaced the humble material of paper above the more rarefied resource of marble in the hierarchy of influential objects for Jesuit art, since paper could travel farther than stone, and at minimal cost, to reach people who might never see the Gesù. But Jesuits were prolific authors themselves, and non-architectural volumes, though greatly valued in their own right, have yet to be explicitly recognized for their structural significance in the synthesis of a Jesuit art. Printed pictures and emblems provided the direction for the crafting of a Jesuit artistic identity hand in hand with an Ignatian spiritual persona, one that was versatile enough to conform to any situation, sufficiently portable for dispersal, and accessible to many regardless of time or place. ${ }^{103}$ It was in paper's apparent "weakness," the fragility and resiliency particularly evident in the flow of the global arena, where its power resided. ${ }^{104}$ Prints provided a material equivalent to the unofficial policy of " $a$ flexu forma" found in Jesuit Carlo Bovio's (1614-1705) emblem book Ignatius insignium epigrammatum et elogiorum centuriis expressus (The most significant expression of hundreds of epigrams and inscriptions [Rome: Ignazio de' Lazzari, 1655]), which exhorted Jesuits to accommodate circumstance, while still maintaining the shared precepts of the Society. ${ }^{105}$ They were where medi-

102 For example, Andrea Pozzo's two-volume Perspectiva pictorum et architectorum [Perspective in architecture and painting] (Rome: Jan Jakub Komárek, 1693-1700), with 118 engraved architectural designs, was partially translated into Chinese as Shixue [The science of vision] (Beijing: Nian Xiyao, 1729). Elisabetta Corsi, La fábrica de las ilusiones: Los jesuitas y la difusión de la perspectiva lineal en China (1698-1766) (Mexico City: El Colegio de México, Centro de Estudios de Asia y África, 2004); Corsi, "Pozzo's Treatise as a Workshop for the Construction of a Sacred Catholic Space in Beijing," in Bösel and Salviucci Insolera, Artifizi della metafora, 232-43; Andrea Pozzo, Perspective in Architecture and Painting: An Unabridged Reprint of the English-and-Latin Edition of the 1693 Perspectiva pictorum et architectorum (Mineola, NY: Dover Publications, 1989).

103 De Boer, Enenkel, and Melion, Jesuit Image Theory; Elisabeth Oy-Marra and Volker R. Remmert, eds., Le monde est une peinture: Jesuitische Identität und die Rolle der Bilder (Berlin: Akademie Verlag, 2011).

104 Michel Serres and Bruno Latour, Conversations on Science, Culture, and Time, trans. Roxanne Lapidus (Ann Arbor: University of Michigan, 1995), 121-23.

105 Carlo Bovio, Ignatius insignium epigrammatum et elogiorum centuriis expressus (Rome: Ignazio de' Lazzari, 1655), 208; Markus Friedrich, "Jesuit Organization and Legislation: Development and Implementation of a Normative Framework," in Županov, Oxford 
tation was composed, multimedia decorative systems were imagined, and missions were systemized. ${ }^{106}$ When the question of a "Jesuit style" is rehabilitated as an inquiry into sources for early modern Jesuit art, the contribution of an art historical underdog, the scrappy yet tenacious reserve of prints, can be given its proper due.

\subsection{The Spiritual Exercises (Exercitia spiritualia)}

Three books structured the first century of Jesuit art: Loyola's Spiritual Exercises (1548), Nadal's Evangelicae historiae imagines (1593), and the Imago primi saeculi Societatis Iesv (1640). It may seem strange to start with a book that was not illustrated originally, like the Spiritual Exercises, to discuss the visual codification of an order's identity. But the Spiritual Exercises was the defining achievement, the first association by either a bystander or a member of the order with the Society of Jesus and its founder, St. Ignatius of Loyola, as seen in the Frontispiece Portrait of St. Ignatius of Loyola from an illustrated Flemish edition, Geestelycke oeffeninghen vanden H. vader Ignatius van Loyola (The Spiritual Exercises of Holy Father Ignatius of Loyola [Antwerp: Michiel Cnobbaert, 1673]) (fig. 2.7). The historian Hugo Rahner, S.J. (1900-68) singled out the Exercises as the inspiration for the ground plan of the Society, and as one of the few books to be continuously in print for over 450 years, its lasting relevance has been corroborated. ${ }^{107}$ St. Ignatius is believed to have begun composing the Spiritual Exercises in Spanish as early as 1523; it was reviewed and practiced by St. Pierre Favre (or Peter Faber, 1506-46), Alfonso Salmerón (151585), and Juan Alfonso de Polanco (1517-76) during the 1530s, and its revised manuscript was definitively approved by Pope Paul III and first published in Latin in Rome in $1548 .{ }^{108}$ Along with the early Directories on giving the Spiritual

Handbook of the Jesuits, 23-43; Levy, Propaganda and the Jesuit Baroque, 177-80, 292, n. 164, fig. 77 .

106 Fabre, "Dossiers bibliographiques," 462-68.

107 Philip Endean, S.J., "The Spiritual Exercises," in Worcester, Cambridge Companion to the Jesuits, 52-67, here 52; Hugo Rahner, s.J., The Spirituality of St. Ignatius Loyola: An Account of Its Historical Development, trans. Francis John Smith, S.J. (Westminster: Newman Press, 1953), 97.

108 Dekoninck, Ad imaginem, 137; St. Ignatius of Loyola, Letters and Instructions, ed. and trans. Martin E. Palmer, S.J., John W. Padberg, S.J., and John L. McCarthy, S.J. (St. Louis, MO: Institute of Jesuit Sources, 2006), 182; John W. O'Malley, S.J., "IX. Early Jesuit Spirituality: Spain and Italy," Religious Culture in the Sixteenth Century (Aldershot: Ashgate, 1993), 3-27, here 3; Moshe Sluhovsky, "A Biography of the Spiritual Exercises," in Maryks, Jesuit Historiography Online, [3]; http://dx.doi.org/10.1163/2468-7723_jho_ COM_19259o (accessed March 13, 2021). The standard critical edition of the Spiritual Exercises is the Monumenta Ignatiana: Series secunda; Exercitia spiritualia Sancti Ignatii 


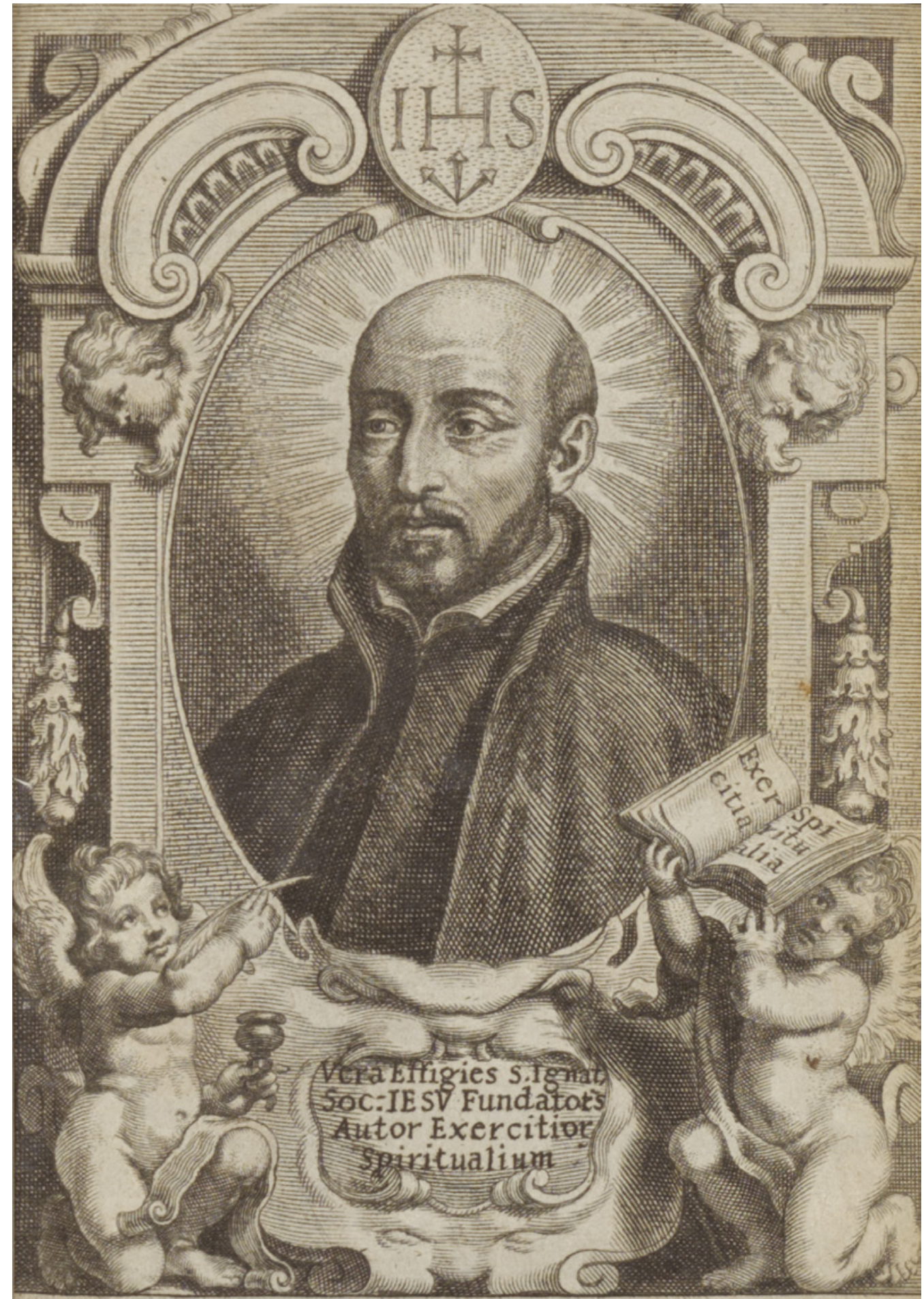

$x$ ÿs quæ Diuino magiftro didicerat N.Zamb:ad Gre 
Exercises, the authorized version is regarded as one of the five major sources on early Jesuit spirituality, together with the Constitutiones et regulae Societatis Iesu (Constitutions of the Society of Jesus); the early biography (through 1538) of St. Ignatius he narrated to Luís Gonçalves da Câmara (1519-75); segments of his spiritual diary; and over seven thousand letters written before his death in Rome on July 31, $1556{ }^{109}$ The Spiritual Exercises occupies a unique place in

de Loyola et eorumque directoria, 3 vols., rev. ed. (Rome: Monumenta Historica Societatis Iesu, 1955). But since David Fleming's and George Ganss's (1905-2000) interpretations are most often used for understanding its meaning in contemporary terms, they are the versions cited throughout this text: David L. Fleming, s.J., ed., Draw Me into Your Friendship: A Literal Translation and a Contemporary Reading of the Spiritual Exercises, Studies on Jesuit Topics 17 (St. Louis, MO: Institute of Jesuit Sources, 1996); George E. Ganss, S.J., ed. and trans., The Spiritual Exercises of Saint Ignatius: A Translation and a Commentary (Chicago: Loyola Press, 1992). For an introduction to the critical editions of the Spiritual Exercises and early manuals on their administration, see Donnelly, Jesuit Writings of the Early Modern Period, 1-31, 156-87; Endean, "Spiritual Exercises," 52-67; St. Ignatius of Loyola, Letters and Instructions; St. Ignatius of Loyola, Personal Writings: Reminiscences, Spiritual Diary, Select Letters, Including the Text of the Spiritual Exercises, ed. and trans. Joseph A. Munitz, S.J., and Philip Endean, s.J., rev. ed.(London: Penguin, 2004); St. Ignatius of Loyola, The Spiritual Exercises and Selected Works, ed. and trans. George E. Ganss, s.J., Classics of Western Spirituality (New York: Paulist Press, 1991); Ignacio Iparraguirre, S.J., Historia de la práctica de los Ejercicios espirituales de San Ignacio de Loyola, 3 vols. (Bilbao: El Mensajero del Corazón de Jesús, 1946-73); Ignacio Iparraguirre, S.J., ed., Directoria Exercitiorum spiritualium (1540-1599), Monumenta Historica Societatis Iesu 76 (Rome: Monumenta Historica Societatis Iesu, 1955); Martin E. Palmer, S.J., ed. and trans., On Giving the Spiritual Exercises: The Early Jesuit Manuscript Directories and the Official Directory of 1599, Jesuit Primary Sources in English Translation 14 (St. Louis, MO: Institute of Jesuit Sources, 1996); Louis J. Puhl, s.J., ed., The Spiritual Exercises of St. Ignatius: Based on Studies in the Language of the Autograph (Chicago: Newman Press, 1951); Joseph Rickaby, S.J., ed., The Spiritual Exercises of St. Ignatius Loyola: Spanish and English with a Continuous Commentary (London: Burns \& Oates, 1915); Moshe Sluhovsky, Becoming a New Self: Practices of Belief in Early Modern Catholicism (Chicago: University of Chicago Press, 2018), 67-95.

109 Of the 6,742 extant letters of St. Ignatius (not including the seventy-three letters discovered later), 6,59o of them came from the last ten years of his life, and most were written by his secretary, Juan de Polanco. Ignatius also kept detailed personal notes of his religious experiences; two bundles of notes, covering thirteen months (early February 1544late February 1545), escaped his attempts to destroy them and were published in 1892. The Monumenta Historica Societatis Iesu is the primary documentary source for the origins of the Society of Jesus, and within this collection, the Monumenta Ignatiana records Ignatius-related writings, and is divided into four parts: (1. Series prima) letters, Sancti Ignatii de Loyola Societatis Iesu fundatoris epistolae et instructiones, 12 vols. 
early modern religious literature as a manual for spiritual reflection, reputedly drawn from Ignatius's personal experiences with God, not from earlier writings, although scholars have noted its debt to cornerstones of late medieval spirituality, like Thomas à Kempis's (c.1380-1471) De imitatione Christi (On the imitation of Christ [c.1418-27]) and the Devotio moderna (Modern devotion) movement in the Netherlands (late fourteenth-sixteenth century), Erasmus of Rotterdam's (1466-1536) Enchiridion militis Christiani (Handbook of a Christian soldier [1501]), and the works of the Alumbrados (Enlightened), practitioners of a mystical Christianity in fifteenth- and sixteenth-century Spain. ${ }^{110}$ The Exercises was divided into four "weeks," more accurately regarded

(Rome: Monumenta Historica Societatis Iesu, 1964-68); (2. Series secunda) the critical edition of the Spiritual Exercises, Exercitia spiritualia Sancti Ignatii de Loyola et eorumque directoria; (3. Series tertiae) the critical Latin and Spanish texts of the Constitutions of the Society of Jesus, Monumenta Ignatiana ex autographis vel ex antiquioribus exemplis collecta: Monumenta Constitutionum praevia, 4 vols. (Rome: Monumenta Historica Societatis Iesu, 1934-38, 1948); (4. Series quarta) and other personal documents, such as memoirs, contemporary evaluations, and the acts of canonization of St. Ignatius, Scripta de Sancto Ignatio de Loyola Societatis Iesu fondatore, 3 vols., rev. ed. (Rome: Monumenta Historica Societatis Iesu, 1943-6o).

110 The Devotio moderna movement, largely spread by the Deventer-based Geert Groote (1340-84), founder of the Brethren of the Common Life, stressed meditation and the search for inner peace. The Alumbrados believed that the human soul had attained a degree of perfection and thus was permitted to enter into direct communication with the Holy Spirit. Michel de Certeau, s.J., "L'espace du désir ou le 'fondement' des Exercices spirituels," Christus, 20, no. 77 (January 1973): 118-28, here 118-19; de Certeau, "The Space of Desire," trans. Michelle Suderman, Artes de México, Edición especial: Arte y espiritualidad jesuitas, 70 (2004): 93-96, here 93; Adrien Demoustier, s.J., "L'originalité des Exercices spirituels," in Les jésuites à l'âge baroque 1540-1640, ed. Luce Giard and Louis de Vaucelles, S.J. (Grenoble: Jérôme Millon, 1996), 23-35, esp. 25; Robert Maryks, "From the IJssel Valley to Paris and Rome via Montserrat," Church History and Religious Culture 101, no. 1 (February 2021): 33-6o; O'Malley, "Early Jesuit Spirituality," 5; Sluhovsky, "Biography of the Spiritual Exercises," [3]; Paul Shore, s.J., "The Vita Christi of Ludolph of Saxony and Its Influence on the Spiritual Exercises of Ignatius of Loyola," Studies in the Spirituality of Jesuits 3o, no. 1 (January 1998): 1-32; Ines G. Županov, "Introduction: Is One World Enough for the Jesuits?," in Županov, Oxford Handbook of the Jesuits, xi-xxxvi, here xviii. For an introduction to the personal spirituality of St. Ignatius, see J. Carlos Coupeau, S.J., From Inspiration to Invention: Rhetoric in the Constitutions of the Society of Jesus (St. Louis, MO: Institute of Jesuit Sources, 2010); Coupeau, "Five Personae of Ignatius of Loyola," in Worcester, Cambridge Companion to the Jesuits, 32-51; Donnelly, Jesuit Writings of the Early Modern Period, 2; Fabre, "First Fathers' of the Society of Jesus," 3-22; Jean-François Gilmont, S.J., Les écrits spirituels des premiers jésuites: Inventaire commenté, Studia ad Historiam Societatis Iesu 3 (Rome: Institutum Historicum Societatis Iesu, 1961); Joseph de Guibert, s.J., The Jesuits: Their Spiritual Doctrine and Practice; A Historical Study, ed. George E. Ganss, s.J., trans. William J. Young, s.J. (St. Louis, MO: Institute of Jesuit Sources, 1986), 21-181, esp. 109-51; St. Ignatius of Loyola, The Constitutions of the Society of 
as stages than necessarily of week-long duration, using the life of Christ as an instrument for personal meditation. The theologian Karl Rahner, S.J. (190484) would attribute the beginning of the modern era of the church to the "immediate experience of God" ("unmittelbare Gotteserfahrung") enabled by the Spiritual Exercises. ${ }^{111}$

The principles delineated in the Exercises would set the tone for Jesuit art as a conscious construction of identity forged by choice and engagement with the world. It could even be claimed that beginning with the Spiritual Exercises is most true to its ambivalent position on imagery, since to do so captures the delicate balance it struck between the generation and negation of the visible. Although a technique intensely reliant on manifold forms of the visual, initial editions of the Spiritual Exercises did not contain imagery: the first printed version, for the exclusive use of the Society, was published by Antonio Blado (1490-1567) in Rome (1548), and its images were limited to a title page with the "IHS" monogram and decorated initial letters. ${ }^{112}$ By the early seventeenth century, illustrated editions of the Spiritual Exercises had begun to appear, such as a 1609 volume printed in Rome by Bartolomeo II Zanetti (fl.1602-21) with simple woodblock prints, consisting of thirty-eight artistically worked

Jesus, ed. George Ganss, S.J. (St. Louis, MO: Institute of Jesuit Sources, 1970); St. Ignatius of Loyola, Letters and Instructions, ix-x; Robert A. Maryks, ed., A Companion to Ignatius of Loyola, Brill's Companions to the Christian Tradition: A Series of Handbooks and Reference Works on the Intellectual and Religious Life of Europe, 500-1800, $5^{2}$ (Leiden: Brill, 2014); Antonio T. de Nicolas, Powers of Imagining: Ignatius de Loyola; A Philosophical Hermeneutic of Imagining through the Collected Works of Ignatius de Loyola with a Translation of These Works (Albany, NY: State University of New York Press, 1986); O'Malley, "Early Jesuit Spirituality," 3-4; John W. O'Malley, S.J., "Some Distinctive Characteristics of Jesuit Spirituality in the Sixteenth Century," Saints or Devils Incarnate?, 165-80; John W. O'Malley, s.J., John W. Padberg, s.J., and Vincent T. O'Keefe, s.J., eds., Jesuit Spirituality: A Now and Future Resource (Chicago: Loyola Press, 1990); Terence O'Reilly, From Ignatius Loyola to John of the Cross: Spirituality and Literature in Sixteenth-Century Spain (Aldershot: Variorum, 1995); O'Reilly, The Spiritual Exercises of Saint Ignatius of Loyola: Contexts, Sources, Reception, Jesuit Studies 31 (Leiden: Brill, 2020); John W. Padberg, S.J., ed., The Constitutions of the Society of Jesus and Their Complementary Norms (St. Louis, MO: Institute of Jesuit Sources, 1996); H. Rahner, Spirituality of St. Ignatius Loyola; Sluhovsky, "Biography of the Spiritual Exercises."

111 Karl Rahner, S.J., "Ignatius of Loyola Speaks to a Modern Jesuit," in Ignatius of Loyola, ed. Paul Imhof, s.J., trans. Rosaleen Ockenden (London: Collins, 1979), 9-38, here 17-18; Sluhovsky, Becoming a New Self, 67.

112 Pierre Antoine Fabre, "Les Exercices spirituels sont-ils illustrables?," in Giard and de Vaucelles, Les jésuites à l'âge baroque, 197-209; Heinrich Pfeiffer, s.J., "Die ersten Illustrationen zum Exerzitienbuch," in Ignatianisch:Eigenart und Methode der Gesellschaft Jesu, ed. Michael Sievernich, S.J., and Günter Switek, S.J. (Freiburg im Breisgau: Herder, 1990), 120-30, here 120. 
"IHS" monograms, at times accompanied by phrases and in a range of sizes and presentations, and many small roundels of biblical scenes. ${ }^{113}$ From the mid-seventeenth century onward, publishers of vernacular versions of the Exercises interwove increasingly refined engravings of classic iconographies of biblical stories with original compositions to highlight the Ignatian gloss on the Christian narrative. ${ }^{114}$ Since the prints were a later supplement to the original text, art historians have tended to eschew study of the illustrated Spiritual Exercises, with notable exceptions, although they supply an important commentary on how the Exercises was envisioned during the first century and a half of its practice. Lydia Salviucci Insolera has cited the inclusion of images in the Spiritual Exercises as one of the great moments in the text's historical evolution, for it shows how the Exercises was originally conceptualized as a visual progression, from the pictorial imagination to the illustrations to the exercitant's mind. ${ }^{115}$ And Dekoninck has shown that new designs, like those executed by Frederick II Bouttats $(c .1610-76)$ in the edition published by Michiel Cnobbaert ( $f$ l.1652-91), were often drawn from other Jesuit spiritual treatises - such as Boetius Bolswert's (c.158o-1633) engravings for Antoine Sucquet's (1574-1627) Viavitae aeternae (The path of eternal life [vol.1: Antwerp: Martin III Nuyts, 1620, vol. 2: Hendrick Aertssens, 1625]) and Herman Hugo's (1588-1629) Pia desideria, emblematis, elegiis et affectibus SS. patrum illustrata (Pious desires, illustrated by emblems, elegies, and affective devotions of the

113 A volume whose spine is labeled "Excert. S. Ignat / Antwerpen 1624" includes twenty fullpage woodcut illustrations, mainly signed "CvS" for Christoffel van Sichem (1581-1658), but several with "EF," sometimes with the date "1624." Copies of this edition are housed in the libraries of Princeton University, the Katholieke Universiteit Leuven, and most recently, Emory University (via David Rüger, Antiquariat Inlibris). Dekoninck, Ad imaginem, 366-67; Pfeiffer, "Ersten Illustrationen zum Exerzitienbuch," 120-30.

114 Fabre mentions an illustrated edition of the Spiritual Exercises, published in Antwerp in 1640. Lydia Salviucci Insolera has studied a 1649 version of the Exercises with twentysix engravings (including a Portrait of St. Ignatius of Loyola), whose innovative designs she has dated to the turn of the seventeenth century, with the year of St. Ignatius's beatification, 1609, as their terminus ante quem. She has attributed them to a Flemish hand, perhaps the young Peter Paul Rubens, who was working on an important series of seventy-nine engravings on the Life and Miracles of St. Ignatius of Loyola at the time. Another edition with engraved images was printed in Rome by the Stamperia di Varese in 1663. Additional engravings were added to the Cnobbaert edition of 1673 . Dekoninck, Ad imaginem, 366-71; Fabre, "Exercices spirituels sont-ils illustrables?," 204; Pfeiffer, "Ersten Illustrationen zum Exerzitienbuch," 120; Lydia Salviucci Insolera, "Le illustrazioni per gli Esercizi spirituali intorno al 16oo," Archivum historicum Societatis Iesu 6o (1991): 161-217, here $184-216$.

115 Demoustier, "Originalité des Exercices spirituels," 26-31; Fabre, "Exercices spirituels sont-ils illustrables?," 197-210; Salviucci Insolera, "Illustrazioni per gli Esercizi spirituali intorno al 16oo," 161-217. 
Holy Fathers [Antwerp: Boetius Bolswert and Hendrik Aertssens, 1624]) thus placing the illustrations of the Spiritual Exercises in the unusual position of channeling both the foundation and the culmination of an early modern Ignatian spirituality. ${ }^{116}$

The iconography of subjects unique to the Spiritual Exercises was governed by the precepts that would become the hallmarks of a Jesuit art. Arresting images like a hand raised in a "stop" gesture for the Examination of Conscience (Examen conscientiae) suggest the Society understood the Spiritual Exercises as a balancing act between personal and group identity (fig. 2.8). A reference to Psalm (119:109), "I hold my life in my hand continually, / but I do not forget your law" ("Anima mea in manibus / meis semper [et legem tuam non sum oblitus.] Ps. 118"), stretches across the palm, reconfiguring a standard mnemonic template into a shared bond between an individual hand and the communal body of law. In the course of navigating private and public spheres, the Spiritual Exercises outlined how a technology of the person could be fused from three modes of self-fashioning: the Examination of Conscience, confession, and spiritual investigation. ${ }^{117}$ In this image, five fingers visualize steps of the Examen: (1) giving thanks to God the Father for blessings received ("1. Gratias age."); (2) seeking the enlightenment of the Holy Spirit through prayer ("2. Pete lumen."); (3) accounting for the soul before a Christ seated in judgment ("3. Examina."); and (4) grieving the crucifixion to ask for forgiveness ("4. Dole."); until (5) the worshiper has been replaced by a Christian knight, the miles Christianus, victorious over the devil, like St. Michael slaying the dragon, and resolved to display improvement ("5. Propone."). ${ }^{118}$ The hand presented a set of tools with which to comprehend one's life, in accordance with St. Augustine of Hippo's (354-430) admonition that to know God, one must first

116 Engravings from the illustrated Spiritual Exercises, such as the Contemplation of Paradise to follow, as well as emblems from Herman Hugo's Pia desideria and plates from Nadal's Evangelicae historiae imagines, were among those sources copied, as woodcuts, for seventeenth-century Bibles (fig. 2.11). Melion and Dekoninck have singled out Boetius Bolswert as an artist whose importance for early seventeenth-century Jesuit spiritual literature deserves more detailed study. Joseph F. Chorpenning, o.s.F.s., ed., Emblemata sacra: Emblem Books from the Maurits Sabbe Library, Katholieke Universiteit Leuven, exh. cat. (Philadelphia: St. Joseph's University Press, 2006), 34-36; Dekoninck, Ad imaginem, 368-71; Walter S. Melion and Ralph Dekoninck, "Jesuit Illustrated Books," in Županov, Oxford Handbook of the Jesuits, $5^{21-52}$, here 530; Mia M. Mochizuki, "Ignatius de Loyola, s.J., Geestelycke oeffeninghen van den H. Vader Ignativs van Loyola (Antwerp: Michiel Cnobbaert, 1673)," in Begheyn et al., Jesuit Books in the Low Countries, 196-201.

117 Sluhovsky, Becoming a New Self, 97 .

118 Fleming, Draw Me into Your Friendship, 38; Ganss, Spiritual Exercises of Saint Ignatius, 38; Salviucci Insolera, "Illustrazioni per gli Esercizi spirituali intorno al 160o," 176. 


\section{EXAMEN CON SCIEN T IAE pqa.49}

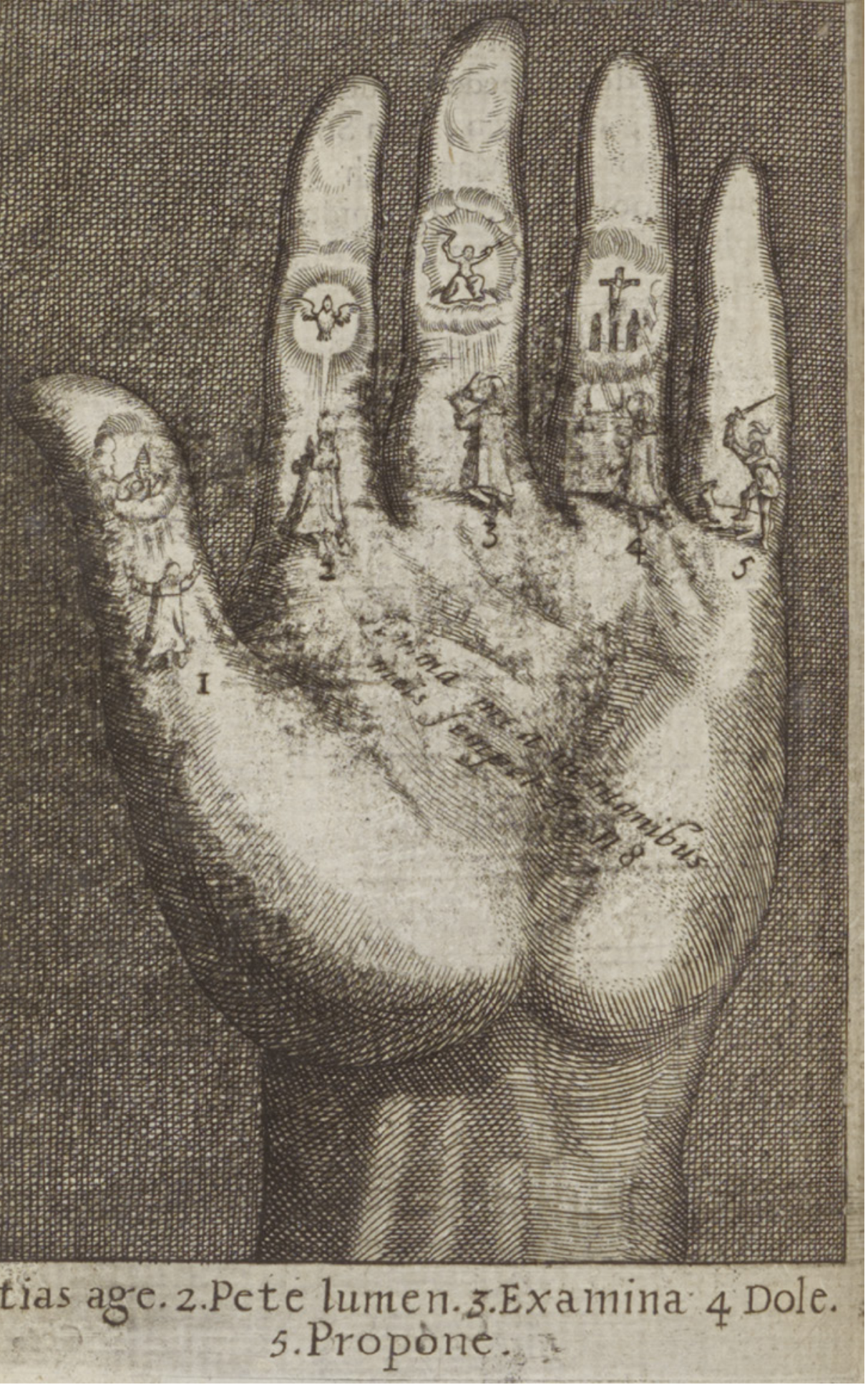


know oneself, and congruent with Jesuit George Aschenbrenner's comment that Ignatius's great accomplishment was to turn the Exercises' Examination of Conscience into a study in consciousness by attuning the self to his or her communication with God. ${ }^{119}$ The Spiritual Exercises did not purport to designate a particular truth; it showed how interrogatory exercises could be internalized as permanent mechanisms of scrutiny and presented a prototype for Jesuit art that was finely attuned to the post-Reformation political moment, whereby questioning drew upon the ancient Greco-Roman moral practice of askesis to improve the soul. ${ }^{120}$ And Michelle Molina has attributed the construction of a modern self to the propagation of such Jesuit techniques of personal examination on mission, a phenomenon borne out by the importance of extra-European picture-making for Jesuit art. ${ }^{121}$

To shape the soul, the Spiritual Exercises supplied a model for operations in the move from a mystical theology to a process-oriented methodological spirituality, where any sense of a "Jesuit style" lay in the procedure it rehearsed. More than an aesthetic style, the Spiritual Exercises systemized the underpinnings of noster modus procedendi, what Favre called a "way to proceed," heeding St. Ignatius's many mentions of an "order" or "form of proceeding," and a "mode that characterizes a procedure" (Spiritual Exercises, v. 119, 204, 350). ${ }^{122}$ But the Spiritual Exercises was intended neither as a prescriptive nor as a proscriptive text: it simply submitted a prompt for the exercitant, something de Certeau

119 George Aschenbrenner, S.J., Consciousness Examen (Chicago: Loyola Press, 2007), 1-3; Karl Enenkel and Walter Melion, eds., Meditatio: Refashioning the Self; Theory and Practice in Late Medieval and Early Modern Intellectual Culture, Intersections: Interdisciplinary Studies in Early Modern Culture 17 (Leiden: Brill, 2011); Sluhovsky, Becoming a New Self, $1-2,20,151$, n. 20.

120 George Aschenbrenner, s.J., "Becoming Whom We Contemplate," The Way, supplement $5^{2}$ (Spring 1985): 30-42, esp. 3o, 35; de Certeau, "Espace du désir ou le 'fondement' des Exercices spirituels," 125-26; de Certeau, "Space of Desire," 95; Pierre Hadot, Philosophy as a Way of Life: Spiritual Exercises from Socrates to Foucault, ed. Arnold I. Davidson, trans. Michael Chase (Oxford: Blackwell Publishing, 1995), 79-44; Paul Rabbow, Seelenführung: Methodik der Exerzitien in der Antike (Munich: Kösel-Verlag, 1954); Sluhovsky, Becoming a New Self.

121 J. Michelle Molina, To Overcome Oneself: The Jesuit Ethic and Spirit of Global Expansion, 1520-1767 (Berkeley: University of California Press, 2013).

122 De Certeau, "Espace du désir ou le 'fondement' des Exercices spirituels," 119; de Certeau, "Space of Desire," 93.

$\leftarrow \quad$ FIGURE 2.8 Frederick II Bouttats, Examination of Conscience, in St. Ignatius of Loyola, Geestelycke oeffeninghen vanden H. vader Ignatius van Loyola, 40, engraving (call no. LP 11.979 A RP). Brussels, Bibliothèque Royale de Belgique, Rare Books PHOTO: (C) BIBLIOTHÈQUE ROYALE DE BELGIQUE 
compared to a libretto with no music, where the crucial text was actually not within it. ${ }^{123}$ The Exercises delivered a series of landmarks for taking readings, not the itinerary of a full voyage, piloted by the exercitant him- or herself, akin to the hypermedia that anticipated the World Wide Web today. O'Malley has observed that the two principal features of the Spiritual Exercises were its clear design and unlimited format, order with freedom as flip sides of the same impulse. ${ }^{24}$ This is why Favre, whom de Certeau has called the best interpreter, distributor, and even co-author of the Spiritual Exercises, appreciated the personal growth and change undertaken in the Exercises and only regarded its text as secondary. ${ }^{125}$ Art historians have too often treated the Spiritual Exercises as a book to be read continuously from start to finish, and interpreted accordingly, despite it being a series of directives that were constantly in flux and highly dependent on a person's specific situation. One of the more ingenious aspects

123 De Certeau, "Espace du désir ou le 'fondement' des Exercices spirituels," 118-19; de Certeau, "Space of Desire," 93. For an introduction to Ignatian spirituality, with attention to the Spiritual Exercises, see James L. Connor, s.J., ed., The Dynamism of Desire: Bernard J.F. Lonergan, S.J., on the Spiritual Exercises of Saint Ignatius of Loyola (St. Louis, MO: Institute of Jesuit Sources, 2006); Philip Endean, S.J., Karl Rahner and Ignatian Spirituality, Oxford Theological Monographs (Oxford: Oxford University Press, 2001); H. Outram Evennett, The Spirit of the Counter-Reformation: The Birkbeck Lectures in Ecclesiastical History Given in the University of Cambridge in May 1951, ed. John Bossy (Cambridge: Cambridge University Press, 1968), 43-66; Rob Faesen, s.J., "Historiography of Jesuit Spirituality," in Maryks, Jesuit Historiography Online; http://dx.doi.org/10.1163/2468 -7723_jho_COM_211568 (accessed March 17, 2021); de Guibert,Jesuits, 152-412, esp. 527-43; Robert A. Maryks, ed., A Companion to Jesuit Mysticism, Brill's Companions to the Christian Tradition: A Series of Handbooks and Reference Works on the Intellectual and Religious Life of Europe, 500-180o, 78 (Leiden: Brill, 2017); William W. Meissner, s.J., To the Greater Glory: A Psychological Study of Ignatian Spirituality (Milwaukee, WI: Marquette University Press, 2013), 62-302; Javier Melloni, S.J., The Exercises of St. Ignatius and Traditions of the East, trans. Michael Kirwan, S.J. (Leominster: Gracewing, 2013); de Nicolas, Powers of Imagining; O'Reilly, From Ignatius Loyola to John of the Cross; William A.M. Peters, S.J., The Spiritual Exercises of St. Ignatius: Exposition and Interpretation, 4th ed. (Rome: Centrum Ignatianum Spiritualitatis, 1980); Hugo Rahner, s.J., Ignatius the Theologian, trans. Michael Barry (New York: Herder \& Herder, 1968), 53-135; H. Rahner, Spirituality of St. Ignatius Loyola; Karl Rahner, s.J., Spiritual Exercises, trans. Kenneth Baker, s.J., 2nd ed. (South Bend, IN: St. Augustine's Press and Deutsche Provinz der Jesuiten, 2014); Sluhovsky, Becoming a New Self, 44-52, 67-95; George W. Traub, S.J., ed., An Ignatian Spirituality Reader: Contemporary Writings on St. Ignatius of Loyola, the Spiritual Exercises, Discernment, and More (Chicago: Loyola Press, 2008), 115-50.

124 O'Malley, "Early Jesuit Spirituality," 5-6.

125 The fact that literacy was no longer a prerequisite for the pursuit of introspection and self-actualization heralded momentous societal change. De Certeau, "Espace du désir ou le 'fondement' des Exercices spirituels," 118-19; de Certeau, "Space of Desire," 93; Endean, "Spiritual Exercises," 52, 64; Moshe Sluhovsky, "St. Ignatius of Loyola's Spiritual Exercises and Their Contribution to Modern Introspective Subjectivity," Catholic Historical Review 99, no. 4 (October 2013): 649-74, esp. 664. 
of the Exercises was that it was conceived as interactive, a practice made, not simply read. Mercurian would affirm:

When merely read, the sacred Scriptures barely move anyone; but when meditated and pondered they are replete with mysteries. Similarly with the Exercises: when merely read, they obviously contain good precepts but move no one very much; when made, however, they are extraordinarily powerful and effective for the conversion of souls and spiritual fruit. ${ }^{126}$

Silvia Mostaccio has pointed to this unrestricted quality as the pivotal link between the formulation of Jesuit pastoral goals and identity, that it was through the form of spiritual governance found in the Exercises, a Jesuit "way of being," not the temporal or geographical stylistic categories asserted in art history, that the distinction between Jesuit and non-Jesuit, and thus Jesuit- and non-Jesuit-related art, was determined. ${ }^{127}$

Within this distinctive framework, the Spiritual Exercises guided the hands-on structuring of identity, personal and pictorial, through the kairos, or the self-defining moment; Ignatius viewed the contingent nature of personal change and daily conversion as the core of the Society. The historian H. Outram Evennett (1901-64) has noted that the Exercises "were in a sense the systematized, de-mysticized quintessence of the process of Ignatius's own conversion and purposeful change of life, and they were intended to work a similar change in others," and Moshe Sluhovsky has portrayed them as "instructions for a modular, ordered, and slow procedure of transforming one's life." ${ }^{128}$ This is the decision depicted in the Spiritual Exercises as the Meditation on the Two Standards above the imperative: "Choose today whom you will serve." ("Eligite hodie cui seruire potissimum debeatis.") (fig. 2.9). ${ }^{129}$ The viewer is confronted with the choice the front figures among an arriving crowd, surrogates for the exercitant, must make between Jesus Christ holding a cross or the devil with his bestial attendants in flames, as the Exercises instructs, between the two banners, "the one of Christ, our Supreme Commander and Lord, the other of Lucifer, the mortal enemy of our human nature" (Spiritual Exercises, v. 136-48). ${ }^{130}$ The Exercises revolved around the potential

\footnotetext{
126 Molina, To Overcome Oneself, 36-37, 43; Palmer, On Giving the Spiritual Exercises, 101-2.

127 Silvia Mostaccio, "Spiritual Exercises: Obedience, Conscience, Conquest," in Županov, Oxford Handbook of the Jesuits, 75-104, here $75^{-80}$.

128 Evennett, Spirit of the Counter-Reformation, 45; Sluhovsky, "St. Ignatius of Loyola's Spiritual Exercises," 663.

129 Salviucci Insolera, "Illustrazioni per gli Esercizi spirituali intorno al 160o," 179.

130 Fleming, Draw Me into Your Friendship, 110-15; Ganss, Spiritual Exercises of Saint Ignatius, 65-67.
} 


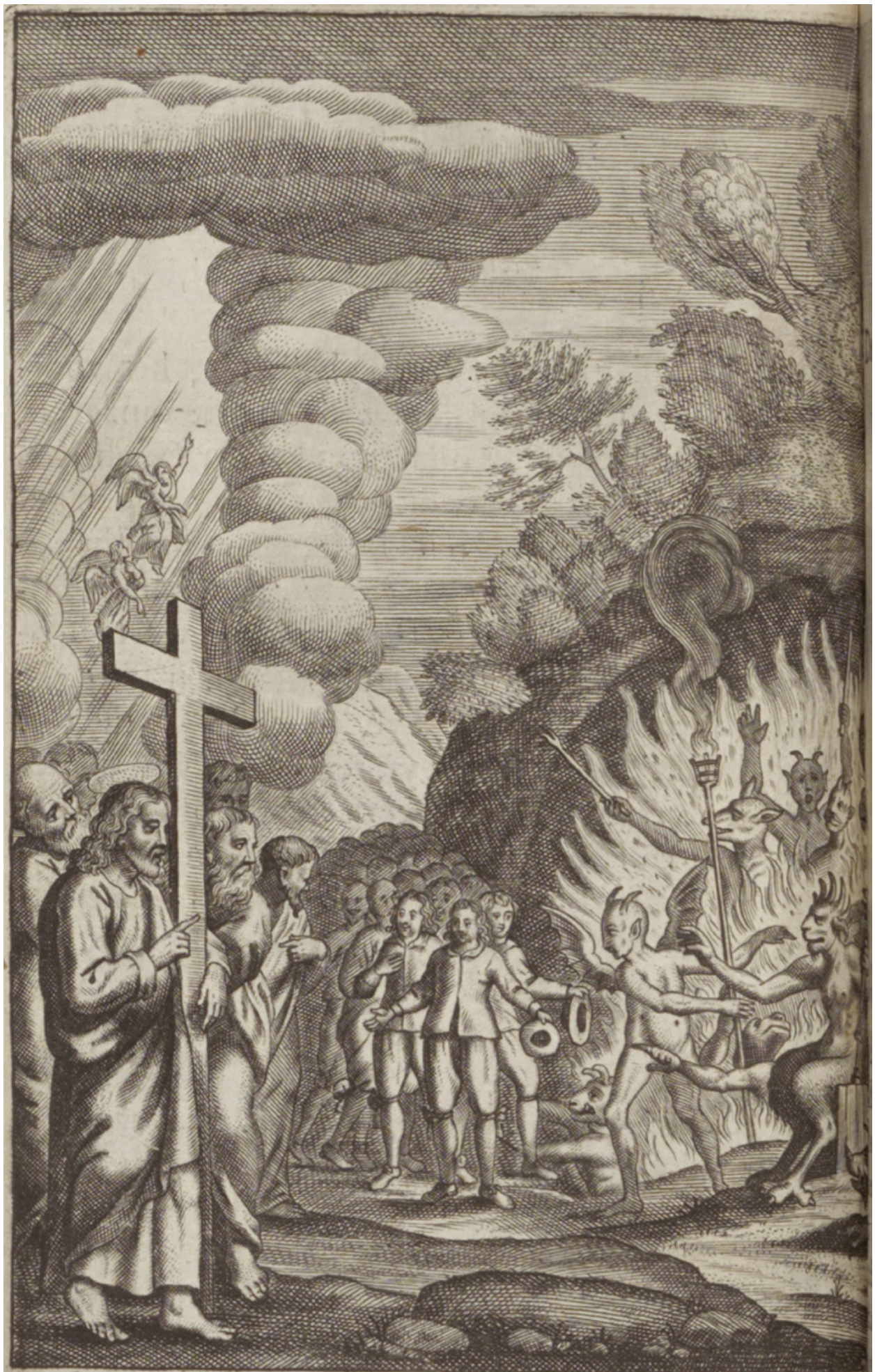

Eligite hodie cui feruire potiffımum debed 
of self-determination at a crossroads in life, the individual's quest to make a decision, called the "Election" in Ignatian terminology, when the exercitant was invited to reject sin and accept God's offer of salvation, and two appendices provided more guidance on the "Discernment of Spirits" (Spiritual Exercises, v. 313-36). ${ }^{131}$ Reflection relied upon what could be thought of as the "spiritual Trinity" of memory, intelligence, and will to navigate the soul through the various instruments that empowered choice (Spiritual Exercises, v. 50). ${ }^{132}$ For Ignatius, biblical exempla could be leveraged to resolve unforeseen, and frequently unprecedented, problems through resolute action. Not least, the Spiritual Exercises presented an optimal method for navigating the predicaments of decision-making on distant mission, of which art was only one ministry, where initiative in the field, often in local conditions that would be

131 Early devotees only completed the Spiritual Exercises two or three times in their life, unlike today's common preference for once a year. De Certeau, "Espace du désir ou le 'fondement' des Exercices spirituels," 119; de Certeau, "Space of Desire," 93; Connor, Dynamism of Desire, 51-56, 81; Dekoninck, Ad imaginem, 139; Endean, "Spiritual Exercises," 62; Fleming, Draw Me into Your Friendship, 243-67; Ganss, Spiritual Exercises of Saint Ignatius, 121-28; Karl Rahner, s.J., The Dynamic Element in the Church (New York: Herder \& Herder, 1964), 84-170; K. Rahner, Spiritual Exercises, 8; Traub, Ignatian Spirituality Reader, 151-222, 251, including "Do You Speak Ignatian? A Glossary of Terms Used in Ignatian and Jesuit Circles," 250-69.

132 Fleming, Draw Me into Your Friendship, 44-45; Ganss, Spiritual Exercises of Saint Ignatius, 41. Jesuits adapted the classical mnemonic techniques expounded by Cicero (106 BCE43 BCE) and Quintilian (c.35-c.10o CE) for missionary purposes, as in Matteo Ricci's "memory palace": Jonathan D. Spence, The Memory Palace of Matteo Ricci (New York: Penguin, 1984). Work on Jesuit image theory has placed the order's art in the context of rhetorical systems through its use of classical modes of moral, emotional, rational, and sensory logic. Melion and Dekoninck have noted the use of three modes of persuasion from book 2 of Aristotle's (384-22 вСЕ) Rhetoric (367-47 and 335-22 вСЕ) in Jesuit illustrated books: ethos, appealing to the speaker's moral authority; pathos, directed to the audience's emotions; and logos, relying on proofs, testimony, and evidence. Within these modes, Jesuit images tended to appeal to visual argumentation through allegoria in factis, an "allegory of facts," drawn from actual persons, things, and events, associated with ethosbased imagery; and allegoria in verbis, an "allegory of words," found in tropes, poetic fictions, and other artificial signs, often seen in pathos-oriented compositions. Aristotle, Art of Rhetoric, trans. John Henry Freese, rev. Gisela Striker, Loeb Classical Library 193, rev. ed. (Cambridge, MA: Harvard University Press, 2020), 166-345; de Boer, Enenkel, and Melion, Jesuit Image Theory; Dekoninck, Ad imaginem, 138-45; Fabre, Ignace de Loyola; Marc Fumaroli, L'âge de l'éloquence: Rhétorique et "res literaria" de la Renaissance au seuil de l'époque classique (Geneva: Librairie Droz, 20o9); Homann, Jerome Nadal, S.J.; Lea, Jerome Nadal, S.J.; Melion, Meditative Art; Melion and Dekoninck, "Jesuit Illustrated Books," 521-22.

$\leftarrow$ FIGURE 2.9 Frederick II Bouttats, Meditation on the Two Standards, in St. Ignatius of Loyola, Geestelycke oeffeninghen vanden H. vader Ignatius van Loyola, 106, engraving (call no. LP 11.979 A RP). Brussels, Bibliothèque Royale de Belgique, Rare Books PHOTO: (C) BIBLIOTHÈQUE ROYALE DE BELGIQUE 
met with limited understanding back in Rome, was required for decisions that needed to maintain orthodoxy and the Jesuit vow of obedience to the pope.

A second integral aspect of the Spiritual Exercises in the creation of a Jesuit identity in art, if one usually conceded obliquely, was its world-affirming spirituality that espoused the "continual dynamic presence of God in all things" from creation onward (Spiritual Exercises, v. 43) and presupposed a liber mundi (book of the world), whose notion of the cosmos saturated the Exercises from start to finish. ${ }^{133}$ On the one hand, the Spiritual Exercises anchored the image of the Principle and Foundation in the past of time immemorial, beginning with the creation of Eve from Adam's rib in the Garden of Eden in the central background directly beneath the rays of God, so the exercitant recognized, after reflection "from end to end," that the course had been set ("Considerandus e finis et suum finem dirigendum est cursus.") (fig. 2.10). ${ }^{134}$ In the foreground, a Rückenfigur, a figure with his back turned to the viewer, provided an avatar for the exercitant, who was likewise meant to see an era of innocence unfold from the fall of man to present circumstance in a world made by and for God (Spiritual Exercises, v. 23). ${ }^{135}$ The logic ran that since God is above the whole world, and not simply the dialectical antithesis to it, he is also to be found in it, worldly and otherworldly, hidden and manifest. ${ }^{136}$ So the exercitant must participate in the world, a position that would come to be subsumed into the famous phrase "contemplative while in action" ("simul in actione contemplativus"), with "while" (simul) being the operative word, often attributed to Nadal. ${ }^{137}$ Only an active agent in the world could effect change, an intentional

133 William A. Barry, S.J., Finding God in All Things: A Companion to the Spiritual Exercises of St. Ignatius (Notre Dame: Ave Maria Press, 1991), 131-39; Dekoninck, Ad imaginem, 30-35; Endean, Karl Rahner and Ignatian Spirituality, 68-98; Fleming, Draw Me into Your Friendship, 38; Ganss, Spiritual Exercises of Saint Ignatius, 38; Howard Hibbard, "Ut picturae sermones: The First Painted Decorations of the Gesù," in Wittkower and Jaffe, Baroque Art, 29-49, here 39, 45-46; Salviucci Insolera, "Illustrazioni per gli Esercizi spirituali intorno al 16oo," 176; O'Malley, "Early Jesuit Spirituality," 9, 18; Traub, Ignatian Spirituality Reader, 47-85, 253-54; Karl Rahner, s.J., "The Ignatian Mysticism of Joy in the World," Theological Investigations (London: Darton, Longman \& Todd, 1961-92), 3:277-93.

134 Salviucci Insolera, "Illustrazioni per gli Esercizi spirituali intorno al 160o," 176.

135 Fleming, Draw Me into Your Friendship, 26-27; Ganss, Spiritual Exercises of Saint Ignatius, 32.

136 K. Rahner, "Ignatian Mysticism of Joy in the World," 291-92.

137 Although the notion of "contemplative while in action," so closely associated with Nadal, had become a catchphrase by the mid-twentieth century, the publication of the fourth

FIGURE 2.10 Frederick II Bouttats, Principle and Foundation, in St. Ignatius of Loyola, Geestelycke oeffeninghen vanden H. vader Ignatius van Loyola, 34, engraving (call no. LP 11.979 A RP). Brussels, Bibliothèque Royale de Belgique, Rare Books PHOTO: (C) BIBLIOTHÈQUE ROYALE DE BELGIQUE 


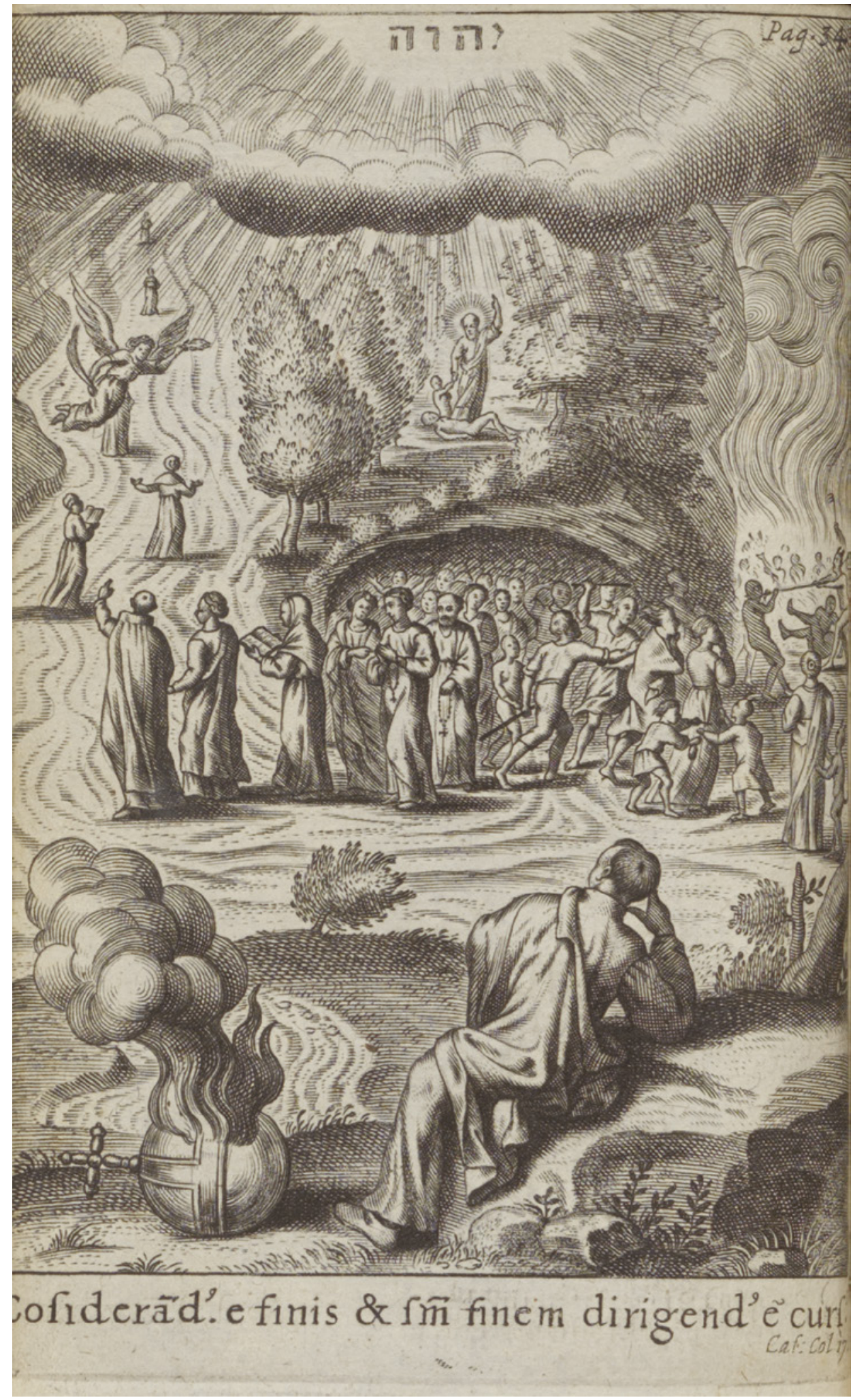


break with cloistered monastic habits, to the point where the charge of trying to introduce a "hermetic spirit" would become a consistent intramural accusation within the Society during its first century.138

On the other hand, the Exercises concluded the "Mysteries of the Life of Christ Our Lord" with a bird's-eye vision of the world in the Contemplation of Paradise that prefaced the unrealized future: "Oh, how unworthy I am to look at the earth with the sky!" ("Heu quam sordet tellus cum coelum aspicio.") (fig. 2.11). ${ }^{139}$ An angelic Rückenfigur raises his or her hands in a gesture of awe at the transformative effect of the Exercises as a frontier zone, between "earth and sky," the effect described by de Certeau as "two practices of space colliding in the field of visibility, one organized by discipline, the other made by astonishment," where "the Foundation creates a vanishing point in relation to those things that can be examined and improved." 140 The interval to discover the place of

volume of the Epistolae P. Hieronumi Nadal Societatis Iesu, ab anno 1546 ad 1577 in 1905 suggested this notion may have originated in a later interpretation of Nadal's thinking. Nadal only used the phrase once (written after Ignatius's death, c.1557) and never developed it further, although he does use the phrase "vita activa superior" (the superior active life) frequently and systematically, and the case could be made that although his language was different, his embrace of this idea remains valid. William Bangert, s.J., Jerome Nadal, S.J., 1507-1580: Tracking the First Generation of Jesuits, ed. Thomas M. McCoog, s.J. (Chicago: Loyola University Press, 1992), 215; Joseph F. Conwell, s.J., Walking in the Spirit: A Reflection on Jeronimo Nadal's Phrase "Contemplative Likewise in Action" (St. Louis, MO: Institute of Jesuit Sources, 2003), xvi-xvii; Emerich Coreth, S.J., "Contemplative in Action," in Contemporary Spirituality, ed. Robert W. Gleason, s.J. (New York: Macmillan, 1968), 184-211, esp. 184, 208-11; Endean, Karl Rahner and Ignatian Spirituality, 69-75; Jerónimo Nadal, Epistolae P. Hieronumi Nadal Societatis Iesu, ab anno 1546 ad 1577 (Madrid: Typis Gabrielis Lopez del Horno, 1898-1962), 4:651-52, 5:162; Miguel Nicolau, S.J., Jerónimo Nadal S.I. (1507-1580): Sus obras y doctrinas espirituales (Madrid: Consejo Superior de Investigaciones Científicas, 1949), 466-67; Nicolau, "Nadal, Jerónimo," in Dictionnaire de spiritualité ascétique et mystique doctrine et histoire, ed. Marcel Viller, S.J. (Paris: Beauchesne, 1937-95), 11:3-15, here 11-12; O'Malley, "Early Jesuit Spirituality," 7; K. Rahner, "Ignatian Mysticism of Joy in the World," 292.

138 O'Malley, "Early Jesuit Spirituality," 21.

139 Salviucci Insolera, "Illustrazioni per gli Esercizi spirituali intorno al 16oo," 181-82.

140 "Deux pratiques de l'espace se heurtant dans le champ de la visibilité, l'une ordonnée à la discipline, l'autre faite d'étonnement." "Le 'Fondement' crée un point de fuite par rapport aux choses qui peuvent être examinées et améliorées." De Certeau, "Espace du désir ou le 'fondement' des Exercices spirituels," 121-24; de Certeau, "Space of Desire," 94-95; Michel de Certeau, S.J., Histoire et psychanalyse entre science et fiction (Paris: Éditions Gallimard, 1987), 56; Fabre, Ignace de Loyola, 325. 


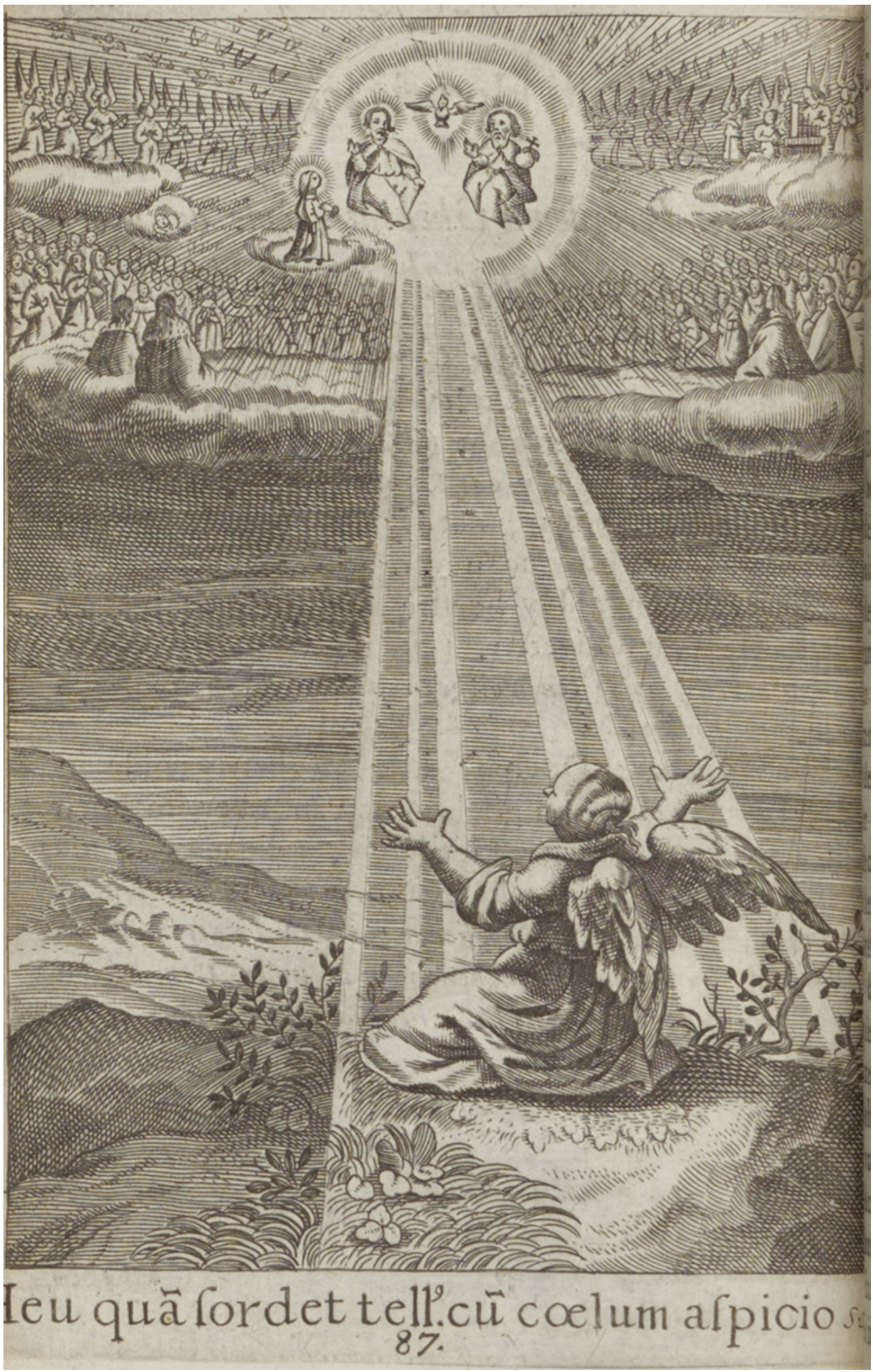


the self between the old path and the choice for the new could only surface in transit, a spirituality well suited to the constant relocation of mission. By opening a rift in the consecutive relation between before and after, the Foundation proposed detachment from an object, a code, or a state of life, where, in accord with Rainer Maria Rilke's (1875-1926) "language of absence," "openness is the poem" and invitation to behavior premised on the constructive juxtaposition of self and world. ${ }^{141}$ Rather than a "Jesuit style," which held little regard for the singular spirituality of the order, de Certeau's insight, that the Spiritual Exercises exhibited a "way of proceeding" in the world that "acquires form by opening up," reveals a practical and conceptually grounded source that could be tailored to wherever Jesuit imagery would lead. ${ }^{142}$

\subsection{The Evangelicae historiae imagines}

Since the Spiritual Exercises was not initially illustrated, Nadal's Evangelicae historiae imagines, published in 1593 by the Antwerp house of the Society of Jesus, may be credited as the earliest pictorial application of the Spiritual Exercises, its Frontispiece bearing Jesus's invitation to the second generation of Jesuits: "Come to me, all you who are weary and burdened, and I will give you rest" ("Venite ad me omnes qvi / laboratis et onerati estis / et ego reficiam vos." [Mt 11:28]) (fig. 2.12). After all, this historic project was undertaken at the express request of Ignatius, who had affirmed that "he [i.e., Nadal] altogether knows my mind and enjoys the same authority as myself," positioning Nadal as the preeminent disseminator of Ignatius's ideas. ${ }^{143}$ The Evangelicae historiae imagines depicted scenes from the life of Christ in the Gospels, coordinated with the liturgical calendar, to instruct Jesuit scholastics in Ignatian meditational techniques for prayer. ${ }^{144}$ In 1595 , the Evangelicae's plates would

141 "La langue de l'absence. [...] L'ouvert, c'est le poème," as quoted in de Certeau, "Espace du désir ou le 'fondement' des Exercices spirituels," 124; de Certeau, "Space of Desire," 95.

142 "Il se forme en s'ouvrant." De Certeau, S.J., "Espace du désir ou le 'fondement' des Exercices spirituels," 128; de Certeau, "Space of Desire," 96.

143 John W. O'Malley, S.J., "To Travel to Any Part of the World: Jerónimo Nadal and the Jesuit Vocation," Studies in the Spirituality of Jesuits 16, no. 2 (March 1984): iv, 1-20, here 3-5. Nicolas Standaert, s.J., "The Composition of Place: Creating Space for an Encounter," The Way 46, no. 1 (January 2007): 7-20, here 12.

144 The Evangelicae historiae imagines was published in Antwerp in 1593 without the names of the engravers or the publisher. The attribution to Hieronymus Wierix was only made explicit in the Adnotationes et meditationes in Evangelia printed by Martin II Nuyts 


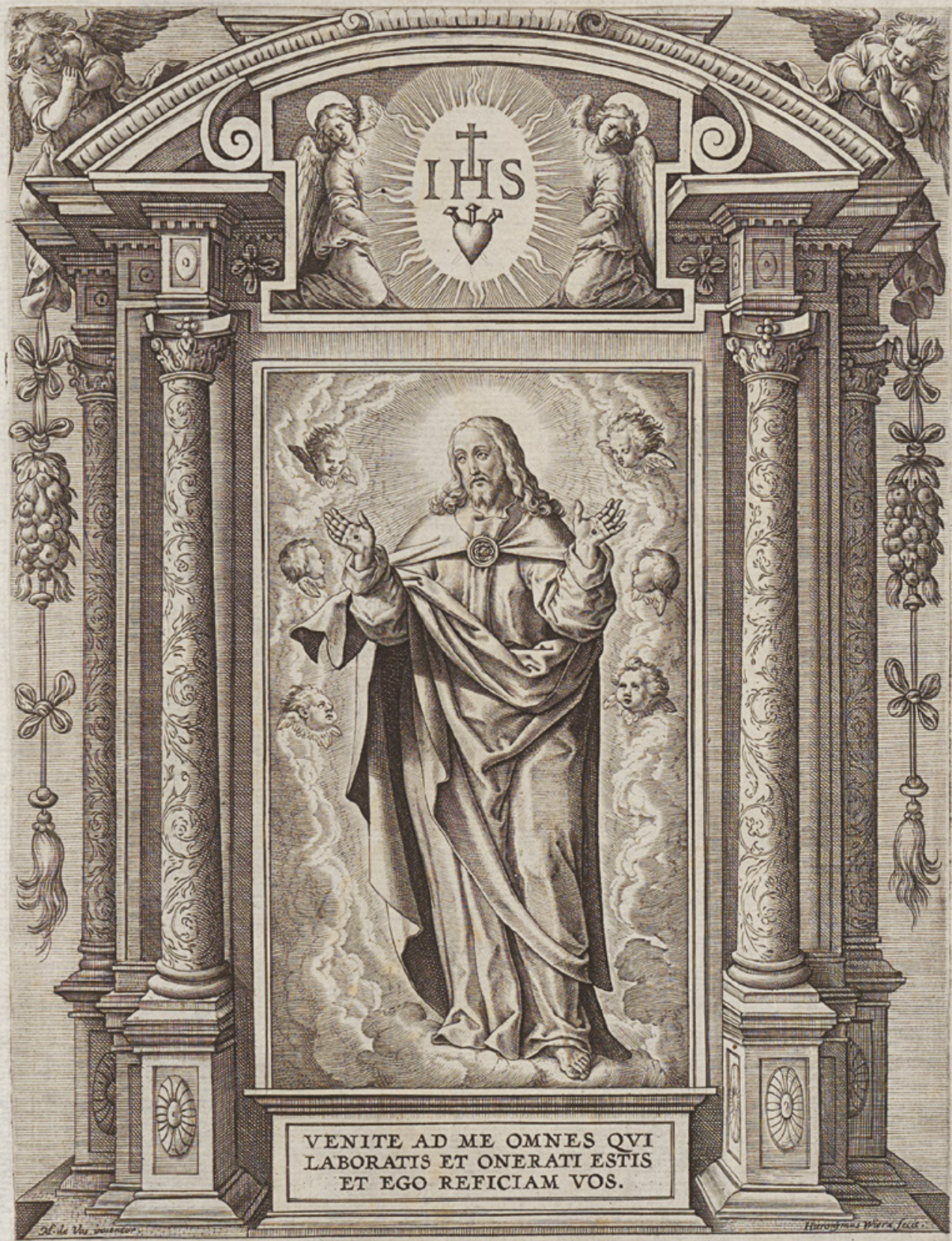

EVANGELIC $A$ E HISTORIAE IMAGINES Ex ordine Euangeliorum, que toto ammo in Miffa facrificio recitantur, In ordinem temporis vita Christi digefte.

Auctore Hieronymo Natali Societatis IESV Theologo Antuerpix Anno Dñi M.D.XCIII .

SVPERIORVM PERMISSV. 
be amplified by meditations and commentary by Nadal, the focus of some images reconfigured, and the number of images expanded, the second edition republished under the title Adnotationes et meditationes in Evangelia quae in sacrosancto Missae sacrificio toto anno leguntur (Annotations and meditations on the Gospels read during the sacrifice of Mass throughout the year [Antwerp: Martin II Nuyts, 1595]). ${ }^{145}$ It was in these refinements to the Evangelicae's core messages that the rapport between interior and exterior sight, so determinative of the identity shown to the world, was polished. The final production

( $f$ l.1586-1608) in Antwerp, which has the year "1594" on the title page, but "1595" at the end of the book and is thus usually assigned to 1595. For an introduction to Nadal's Evangelicae historiae imagines, see Ralph Dekoninck, "A Graphic Koiné for a New Religious Value: The Visual Translatability of the Evangelicae historiae imagines," in Trading Values in Early Modern Antwerp, ed. Christine Göttler, Bart Ramakers, and Joanna Woodall, Nederlands Kunsthistorisch Jaarboek 64 (Leiden: Brill, 2014), 272-96; Dekoninck et al., eds., Genèse, structure et postérité des Evangelicae historiae imagines de Jérôme Nadal (Paris: École Française de Rome, forthcoming); Homann, Jerome Nadal; Lea, Jerome Nadal; Marie Mauquoy-Hendrickx, Les estampes des Wierix (Brussels: Bibliothèque Royale Albert $\mathrm{I}^{\mathrm{er}}$, 1978-83), 3, part 1:400-29, pl. 306-25, figs. 1989-2141; Mauquoy-Hendrickx, "Les Wierix illustrateurs de la Bible dite de Natalis," Quaerendo 6 (1976): 28-63; Melion and Dekoninck, "Jesuit Illustrated Books," 524-26; Paul Rheinbay, s.A.C., Biblische Bilder für den inneren Weg: Das Betrachtungsbuch des Ignatius-Gefährten Hieronymus Nadal (Egelsbach: Hänsel-Hohenhausen, 1995); Max Rooses, "De Plaatsnijders der Evangelicae historiae imagines," Oud Holland 6 (1888): 277-88; Dietmar Spengler, "Die Ars jesuitica der Gebrüder Wierix," Wallraf-Richartz-Jahrbuch 57 (1996): 161-94; Jan Van der Stock, "Introduction," in Hollstein's Dutch and Flemish Etchings, Engravings, and Woodcuts, 14501700. The Wierix Family. Book Illustrations, ed. Jan Van der Stock (Ouderkerk aan den IJssel: Sound \& Vision Publishers, 2006-7), 71, part 2:3-7; Maj-Brit Wadell, "The Evangelicae historiae imagines: The Designs and Their Artists," Quaerendo 10 (1980): 279-91; Wadell, Evangelicae historiae imagines: Entstehungsgeschichte und Vorlagen, Gothenburg Studies in Art and Architecture 3 (Gothenburg: Eric Lindgrens Boktryckeri, 1985).

145 Like many early modern books, the Adnotationes et meditationes in Evangelia would continue to be revised in successive printings. A second edition appeared in 1596, and Carlo Scribani (or Clarus Bonarscius, 1561-1629), then rector of the Jesuit College in Antwerp, sold the plates to the publisher Jan I Moretus in 1605, who, in turn, produced a new version in 1607. Karen L. Bowen and Dirk Imhof, "Publishing and Selling Jerónimo Nadal's Trend-Setting Evangelicae historiae imagines and Adnotationes et meditationes in evangelia: Dealings with the Moretuses, 1595-1645," The Library, 7th series, 20, no. 3 (September 2019): 307-39. Jozef Jennes, C.I.C.M., Invloed der vlaamsche prentkunst in Indië, China en Japan tijdens de XVI ${ }^{e}$ en XVII eeuw (Leuven: Davidfonds, 1943), 86; Walter S. Melion, "The Art of Vision in Jerome Nadal's Adnotationes et meditationes in Evangelia," in Homann, Jerome Nadal, 1:1-96, here 73; Melion, "Quis non intelliget hoc voluissse Christum: The Significance of the Redacted Images in Jerónimo Nadal's Adnotationes et meditationes in Evangelia of 1595," in Lea, Jerome Nadal, 1-99. Unless otherwise specified, I use the title of the first text, Evangelicae historiae imagines, to refer to the whole project, including the Adnotationes et meditationes in Evangelia. 
would be the largest, most complex, and finely engraved series of prints ever commissioned by the Jesuits and would contain 153 folio-size printed images, engraved by Johannes (or Jan, 1549-c.1620) Hieronymus (1553-1619), and Antoon II (c.1552-c.1604) Wierix, Adriaen (c.156o-1618) and Jan II Collaert $(c .1561 / 66-c .1620 / 28)$, and Karel de Mallery (1571-c.1635). ${ }^{146}$ Antwerp presses provided an important voice for Catholic reform, one that Nadal would have been familiar with from his time as visitor to the province of Flanders during the 156 os, and they printed the bulk of works on Ignatian spirituality. ${ }^{147}$ The Evangelicae was one of the earliest illustrated Jesuit books in Antwerp, after Christophe Plantin's ( $f$ l.1548-89) woodcut-supplemented editions of Peter Canisius's (or Pieter Kanis, 1521-97) Institutiones Christianae pietatis, seu parvus catechismus Catholicorum (Christian institutes, or small Catholic catechism [Antwerp: Christophe Plantin, 1566, rep. ed. 1574]). ${ }^{148}$ Nadal would not live to see the completion of his magnum opus, as it would not reach its final state until about fifteen years after his death on April 3, 1580, but the Evangelicae historiae imagines/Adnotationes et meditationes in Evangelia project is still counted as one of his greatest legacies.

The emphasis on the visual disposition of place was how Nadal distinguished his work from earlier illustrated books, like Frans de Costere's (15321619) Vyftich meditatien van de gantsche historie der Passie en des lijdens Ons Heeren Jesu Christi (Fifty meditations on the whole history of the passion and suffering of Our Lord Jesus Christ [Antwerp: Christophe Plantin, 1587]), the first pictorial life of Christ composed for a Jesuit text and an important

146 The plates, including the Frontispiece, have been assigned as: fifty-eight by Anton II Wierix, fifty-seven by Hieronymus Wierix, seventeen by Jan Wierix, eleven by Adriaen Collaert, nine by Karel de Mallery, one by Jan II Collaert, and one by an unknown engraver with the monogram “I.N." Rooses, "Plaatsnijders der Evangelicae historiae imagines," 278.

147 Nadal was in Antwerp at least in June 1562 and from October ${ }^{1567}$ through June 1568; he was appointed visitor to the provinces of Germany, Belgium, and France on February 7 , 1566. Dekoninck, Ad imaginem, 370-71; Dekoninck, "Founding of a Jesuit Imagery," 34147; Dekoninck, "Invention de l'image de la Compagnie de Jésus entre Rome et Anvers," 166-82; Fabre, Ignace de Loyola, 21, 192-207; Manuel Insolera and Lydia Salviucci Insolera, La spiritualité en images aux Pays-Bas Méridionaux dans les livres imprimés des XVI et $X V I I^{e}$ siècles conservés à la Bibliotheca Wittockiana, Miscellanea Neerlandica 13, exh. cat. (Leuven: Peeters, 1996); Nadal, Epistolae P. Hieronumi Nadal Societatis Iesu, ab anno 1546 ad 1577, 1:747, 2:571, 593-96, 80o.

148 Many of the earliest illustrated books published by Christophe Plantin for the Society had prints designed by Peeter van der Borcht (1545-1608), his preferred engraver, who made sure the images carefully aligned with the meaning of the texts. Van der Borcht's work for Jesuit publications and the fact that the Wierixes were the last choice of engravers for the Evangelicae historiae imagines project are both topics worthy of additional study. Fabre, Ignace de Loyola, 192-207; Melion and Dekoninck, "Jesuit Illustrated Books," 522-23. 
in-house antecedent for the Evangelicae. ${ }^{149} \mathrm{He}$ achieved this by an extraordinary four-part, word-image composition, as seen in the Adoration of the Magi (Mt 2[:1-12]), from top to bottom: (1) the Gospel text; (2) the image with major events and locations marked by letters; (3) expanded upon at the bottom of the page with annotations for exegetical or historical elements of the text; and (4) completed with a meditation on the subsequent pages, often in colloquy form (fig. 2.13)..$^{150}$ The purpose of Nadal's compounded structure was to conjure up the Spiritual Exercises' well-known "composition of place" (compositio loci) through the application of the senses, which has been expressed as "ex libera meditatione," giving free rein to the imagination in prayer to leave the devotee open to God's direction. ${ }^{151}$ In the first meditation of the Spiritual Exercises, Ignatius had advised:

149 For image precedents for Nadal, including Dat leven ons Heeren Christi Iesu figuerlijk wten text der vier Euangelisten (The life of Our Lord Jesus Christ, based upon the text of the four evangelists), sometimes called the Iesu Christi vita (The life of Jesus Christ), by the Carthusian Willem van Branteghem (1480-1537) (Antwerp: Mattheus Crom, 1537), see Melion and Dekoninck, "Jesuit Illustrated Books," 523-24; Birgit Ulrike Münch, Geteiltes Leid: Die Passion Christi in Bildern und Texten der Konfessionalisierung (Regensburg: Schnell \& Steiner, 2009), 190-97.

150 Each image is entitled with a Latin caption of the subject above citations to the biblical chapter and the year since Christ's birth, placing the image within a biblical timeline. In the top-right margin of the page, the Arabic number refers to the plate number and the Roman number to the chapter detailing the associated religious feast. The lower margin provides the key to the letters in the image. Homann, Jerome Nadal; 1:155-67; Mauquoy-Hendrickx, Estampes des Wierix, 3, part 1:402, pl. 307, fig. 1997.

151 Walter S. Melion, "The Apparitiones Christi (Appearances of the Risen Christ) in Jerónimo Nadal's Adnotationes et meditationes in Evangelia," Meditative Art, 105-5o; Melion, "Art of Vision in Jerome Nadal's Adnotationes et meditationes in Evangelia," 1-96; Melion, "Ex libera meditatione: Visualizing the Sacrificial Christ in Jerónimo Nadal's Annotations and Meditations on the Gospels," in The Passion Story: From Visual Representation to Social Drama, ed. Marcia Kupfer (University Park, PA: Pennsylvania State University Press, 2008), 91-118; Melion, "Haec per imagines huius mysterij ecclesia sancta [clamat]: The Image of the Suffering Christ in Jerome Nadal's Adnotationes et meditationes in Evangelia," in Homann, Jerome Nadal, 2:1-73; Melion, "Mortis illius imagines ut vitae: The Image of the Glorified Christ in Jerome Nadal's Adnotationes et meditationes in Evangelia," in Homann, Jerome Nadal, 3:1-32, esp. 4, 7, 22; Melion, "Parabolic Analogy and Spiritual Discernment in Jerónimo Nadal's Adnotationes et meditationes in Evangelia," in The Turn of the Soul: Representations of Religious Conversion in Early Modern Art and Literature, ed. Lieke Stelling, Harald Hendrix, and Todd M. Richardson (Leiden: Brill, 2012), 299-339; Melion, "Virtutis tacitate ut lumina non videant? (Do They Not See the Light of Silent Virtue?): Love, Judgment, and the Trope of Vision in Benito Arias Montano's Divinarum nuptiarum

FIGURE 2.13 Hieronymus Wierix, Adoration of the Magi, in Nadal, Adnotationes et meditationes in Evangelia, pl. 7, engraving (call no. LP 9.386 C RP). Brussels, Bibliothèque Royale de Belgique, Rare Books PHOTO: (C) BIBLIOTHÈQUE ROYALE DE BELGIQUE 


\section{ADORATIO MAGORVM. Matth. $\ddot{y}$. Anno $i$.}

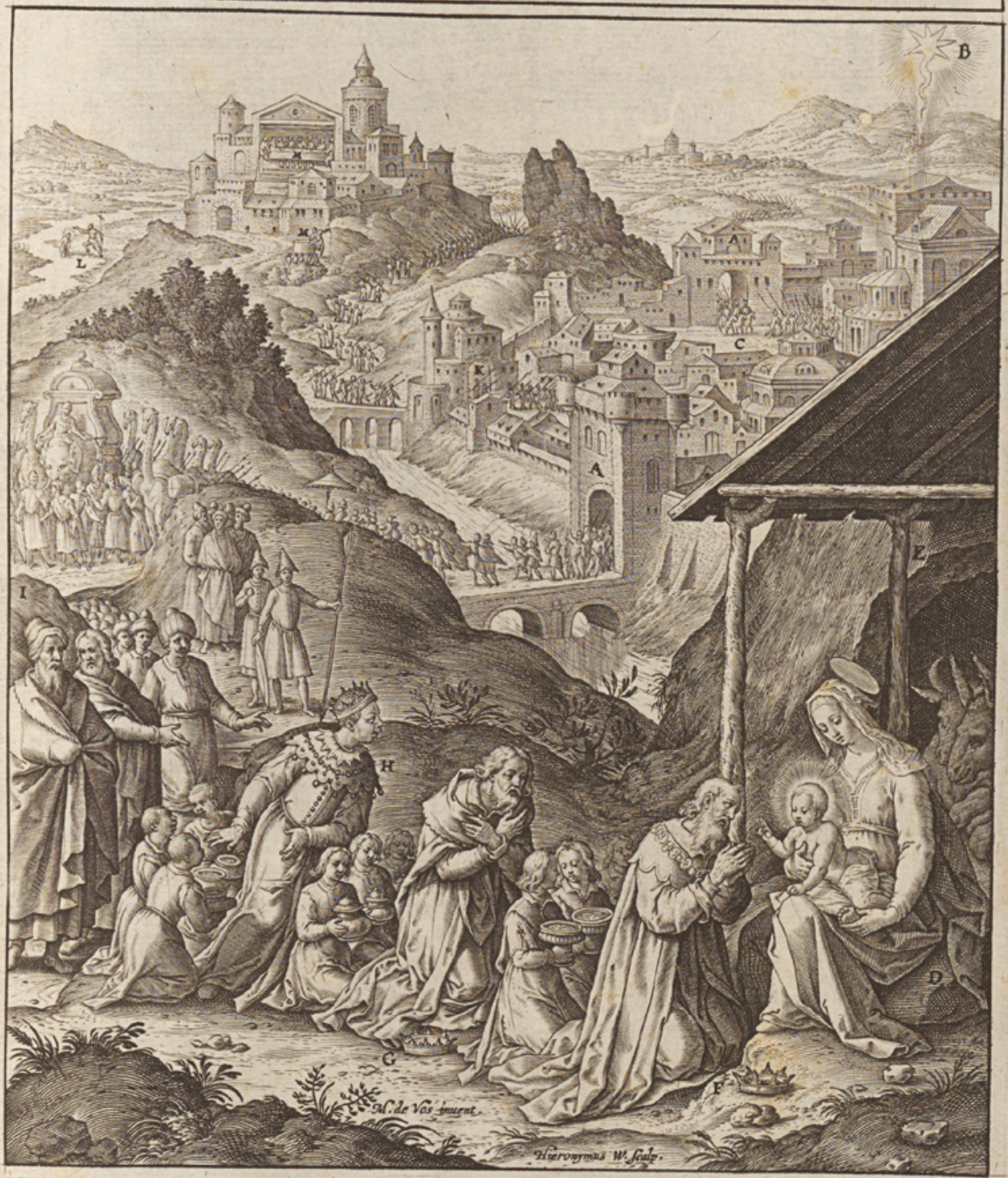

A. Bethlehem, quo iter habent Magi.

B. Stella os tendit vbi IESVS erat.

C. Magi Bethlehem ingreßi: extra vrbem enim illos opportuit defcribere, quemad. modam reliqua, $v t$ esfent conspicua.

D. Maria Jola cum Puero ad os Jpelunca.

E. Bos Es afinus ad Praefepe.

F. Primus Rex IESVM adomit, of offert tria munera.
G. Alter Se compant ad adorationem, $b$ munera totidem in promptu habet. H. Tertius fua parans dona venerabundus expectat.

I. Aulici ommes fimiliter emmus adorant.

K. Magi alia via domum reuertuntur.

L. Chris ti baptifmus ad Bethabaram.

M. Nuptia in Cana Galilara. 
The composition will be to see in imagination the physical place where that which I want to contemplate is taking place. By physical place I mean, for instance, a temple or a mountain where Jesus Christ or Our Lady happens to be, in accordance with the topic I desire to contemplate. ${ }^{152}$

At the start of the second week, the exercitant was asked to immerse him- or herself in the kingdom of God through a series of topoi in the "Contemplation of the Kingdom of Christ," to imagine the "synagogues, villages, and cities through which Christ wandered while preaching, and also other places" (Spiritual Exercises, v. 91). ${ }^{153}$ With the indication of presence by geographic reference points and the citation of local, regional, and universal contexts, the Spiritual Exercises showcased the locative imagination from a kaleidoscope of perceptive, representative, and introspective viewpoints. ${ }^{154}$

Under Nadal's guidance, Melion has remarked, if the annotations detailed the experience of the composition of place in the Spiritual Exercises, the meditations provided the rhetorical devices to transform place into spaces of contemplation. ${ }^{155}$ For example, in Nadal's Adoration of the Magi, the episode was recreated like a theatrical mise en scène. The reflection begins at the entry gate to Bethlehem in the central middle ground (A); leaping up to the star in the upper-right corner that directed the Magi to Jesus's location (B); then boomeranging back to another gate, where they entered the city $(\mathrm{C})$, with a smaller " $\mathrm{A}$ " to underscore the motif's repetition, reenacting the path of the Magi; before reaching the scene's subject in the right foreground, the Virgin cradling the Christ Child before a cave (D). In this telling, the story is one of constant, staggered approach, from ox and donkey (E); to the three kings lined up to hand over their gifts $(\mathrm{F}-\mathrm{H})$; and a seemingly endless stream of figures winding over hill and dale, crossing a bridge from the city to adore the baby Jesus (I). The narrative then closes through the vocabulary of place: the Magi return home through another gate to the city $(\mathrm{K})$; coming full circle back to the scene's starting point, before repeating the initial sequence in reverse, this time to the left extreme background of Christ's baptism in Bethlehem (L); crowned by the wedding in the fortified mountain-top compound of Cana (M). This rehearsal

conventa et acta and Christi Jesu vitae admirabiliumque actionum speculum," Meditative Art, 37-104; Münch, Geteiltes Leid, 161-98.

$15^{2}$ Spiritual Exercises, v. 47. Fleming, Draw Me into Your Friendship, 42-43; Ganss, Spiritual Exercises of Saint Ignatius, 40.

153 Fleming, Draw Me into Your Friendship, 82-83; Ganss, Spiritual Exercises of Saint Ignatius, 53.

154 De Certeau, "Espace du désir ou le 'fondement' des Exercices spirituels," 119; de Certeau, "Space of Desire," 93; Fabre, Ignace de Loyola.

155 Melion, "Art of Vision in Jerome Nadal's Adnotationes et meditationes in Evangelia," 2. 
of a series of sites conferred a topographical organization on the pictorial narrative and demonstrated how a "way of proceeding" could be retrofitted as an Ignatian "way of looking" through place. ${ }^{156}$

The intention to explore place as a meditational technique can already be traced in the notoriously complicated genesis of the Evangelicae: from its motivation to the arbitration of immediate and ancient predecessors, from the logistics of commissioning the right artists to its approval by author and superior general, and from the first edition through its determinative revisions for the Adnotationes et meditationes in Evangelia. ${ }^{157}$ Thanks to the pioneering work of Maj-Brit Wadell, the first drawings for the Evangelicae, likely supervised by Nadal himself and today housed in the Biblioteca Nazionale in Rome, have been assigned to the Roman artist Livio Agresti (1508-80) from the late 1550s or early 156os, like this study for the Adoration of the Magi (fig. 2.14). The use of letters in the pictorial field for elaboration below already appears, but pictorial focus at the beginning of the development of the idea was trained on the numbers of figures weaving through an undifferentiated swath of landscape. A second set of red chalk drawings in Windsor Castle, attributed to the Florentine Fiammeri and produced around 1579-85, re-oriented Agresti's horizontal compositions to vertical ones, tightening the connections between figures in the foreground with the incorporation of several buildings, as seen for this subject in the middle ground (fig. 2.15). It was these new configurations that were copied in a third set of ink drawings in the Bibliothèque Royale de Belgique in Brussels by Bernardino Passeri $(c .1530 / 40-96)$, working in the mid-158os, who concentrated attention on the main figures, honing narratives for historical accuracy and transforming the atmospheric impressions of Fiammeri's red-chalk drawings into pen and ink modelli that the printmakers would find legible enough for incising plates (fig. 2.16). Passeri's drawings then

${ }_{156}$ De Certeau, "Espace du désir ou le 'fondement' des Exercices spirituels," 119; de Certeau, "Space of Desire," 93; Fabre, Ignace de Loyola, 19, 22, 207-10.

157 Although the third superior general of the Society of Jesus, Borja, commissioned the work, it was left to his successor, Mercurian, to oversee its production in a distinctly Flemish idiom. Dekoninck, "Founding of a Jesuit Imagery," 342-43; Dekoninck, "Graphic Koiné for a New Religious Value," 278-82; Dekoninck, "Invention de l'image de la Compagnie de Jésus entre Rome et Anvers," 167-79; Dekoninck et al., Genèse, structure et postérité des Evangelicae historiae imagines de Jérôme Nadal; Fabre, Ignace de Loyola, 163-263; Mahíques, "Francisco de Borja y la visualidad jesuítica," 586-87; Mauquoy-Hendrickx, "Wierix illustrateurs de la Bible dite de Natalis," 28-63; Melion, "Art of Vision in Jerome Nadal's Adnotationes et meditationes in Evangelia," 1-96; Melion, "Quis non intelliget hoc voluissse Christum," 1-99, esp. 2-5; Melion and Dekoninck, "Jesuit Illustrated Books," 52426; Rheinbay, Biblische Bilder für den inneren Weg; Wadell, "Evangelicae historiae imagines," 279-91; Wadell, Evangelicae historiae imagines. 


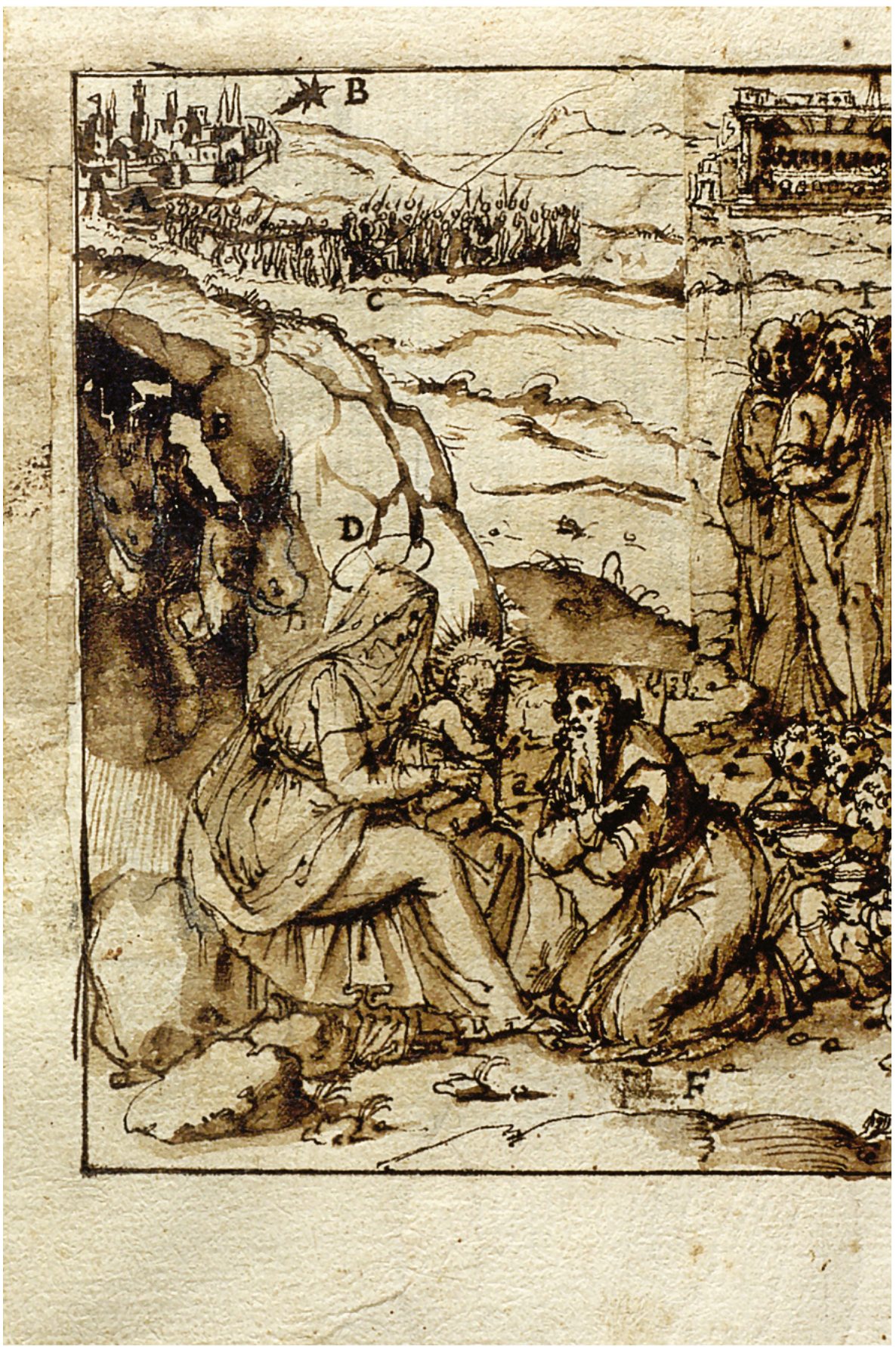

FIGURE 2.14 Livio Agresti, Adoration of the Magi, c.1555-62, brown ink on paper (inv. no. 71.4.F.1/7). Rome, Biblioteca Nazionale Centrale "Vittorio Emanuele II," Sala Manoscritti e Rari PHOTO: (C) BIBLIOTECA NAZIONALE CENTRALE "VITTORIO EMANUELE II" 


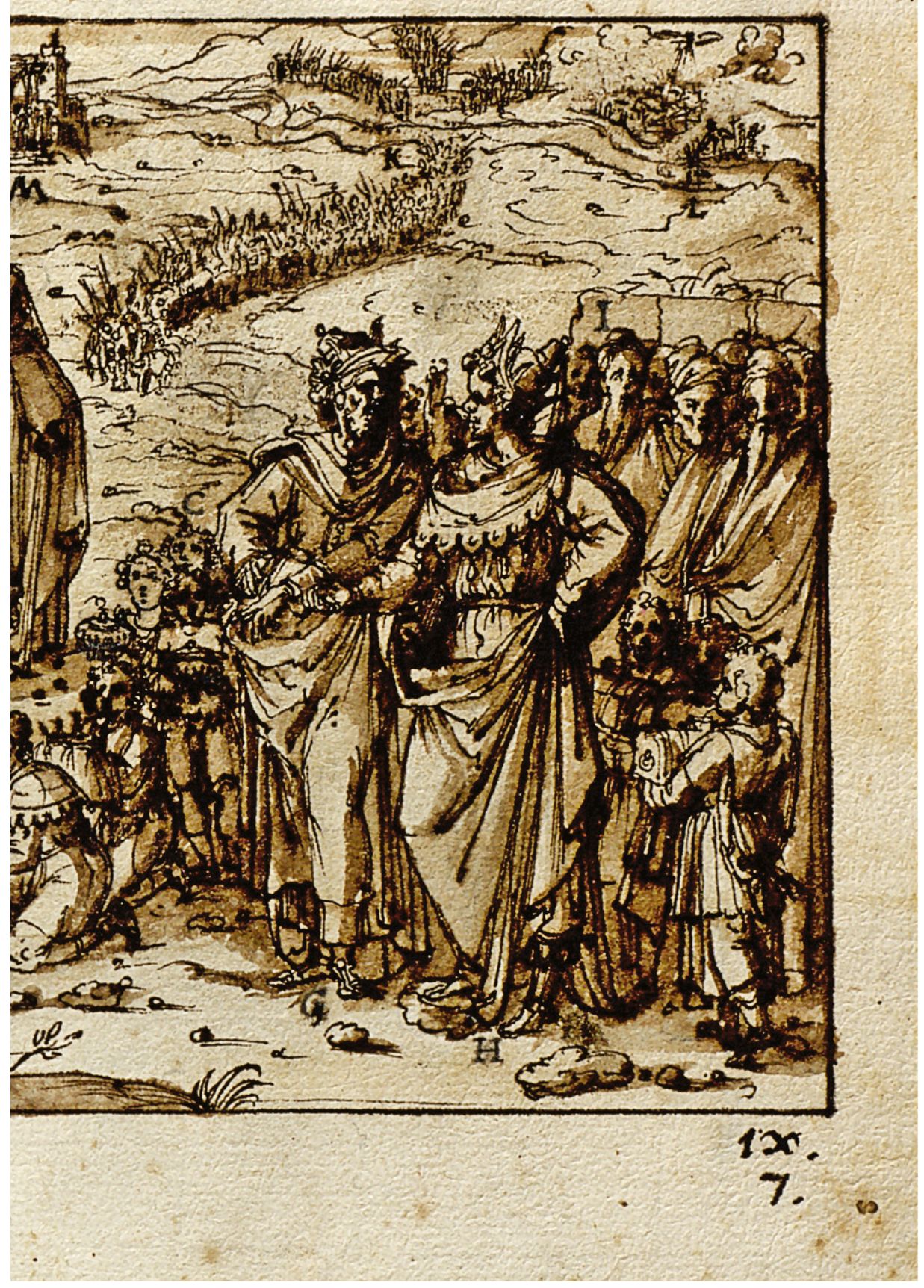




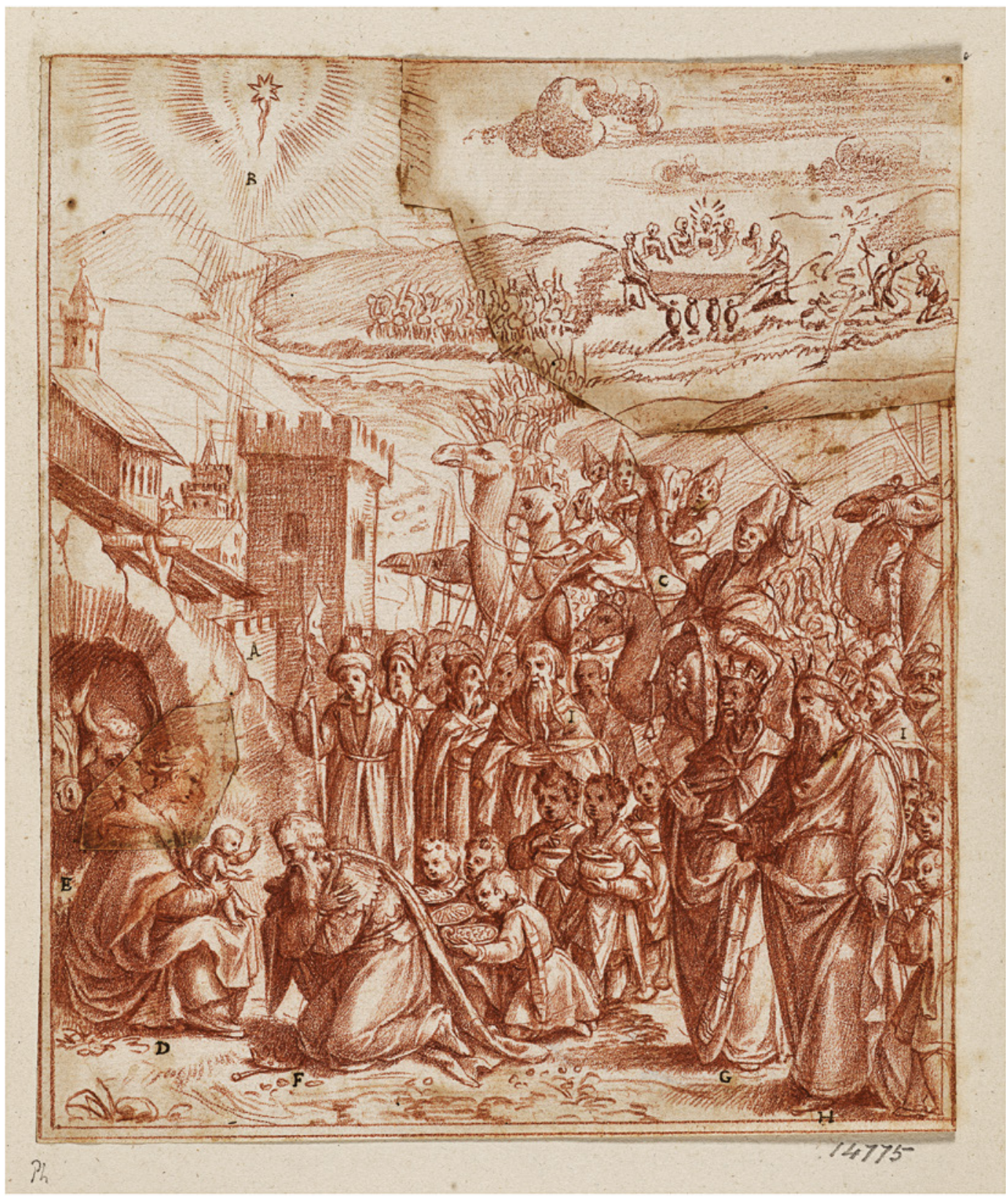

FIGURE 2.15 Giovanni Battista Fiammeri (attributed), Adoration of the Magi, c.1579-85, red chalk on paper (inv. no. 914775). Windsor, Windsor Castle PHOTO: ( ) HER MAJESTY QUEEN ELIZABETH II 2020/ROYAL COLLECTION TRUST 


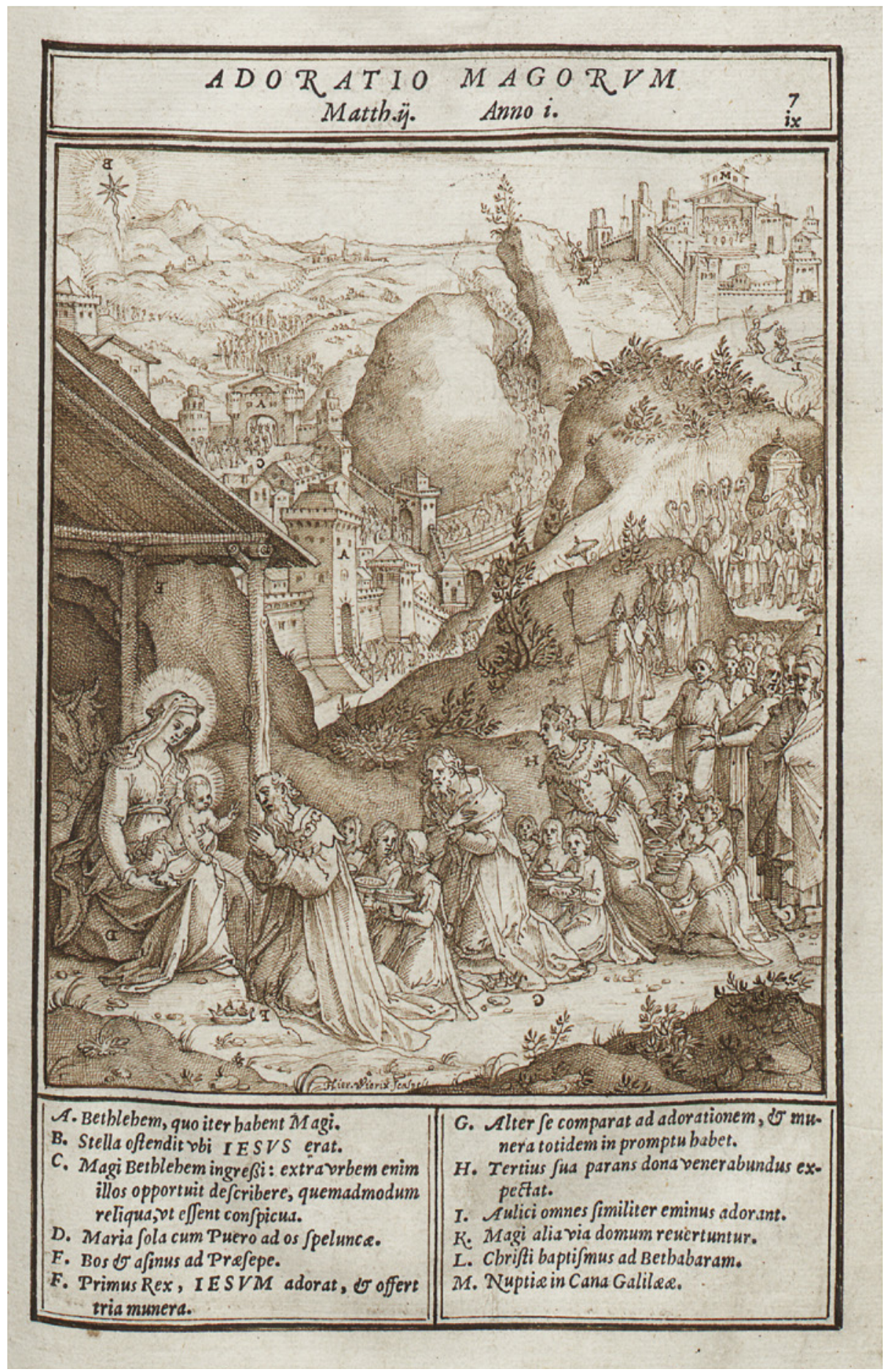

FIgURE 2.16 Bernardino Passeri and Maerten de Vos, Adoration of the Magi, in Jerónimo Nadal, Evangelicae historiae imagines (Rome: Society of Jesus, 1586), pen and brown ink on paper, pl. 7 , fol. I24 ${ }^{\mathrm{r}}$ (call no. DES RES $4^{\mathrm{o}-\mathrm{XVI}}{ }^{\mathrm{e}}$ s. italien-Bernardino Passeri-VB $65^{8}$ ${ }_{4 C}$ ). Brussels, Bibliothèque Royale de Belgique, Prints and Drawings PHoto: (C) BIBLIOTHÈQUE ROYALE DE BELGIQUE 
formed the basis for the first engravings that would be redesigned by Maerten de Vos (1532-1603), often with the architectural settlements visible here, and it is de Vos's compositions that the Wierixes, the Collaerts, and de Mallery would sharpen into the site-driven imagery, now with a substantial urban landscape, displayed in the horizontally reversed, definitive designs (figs. 2.13, 2.16). ${ }^{158}$ Place was the imagined pictorial vernacular by which Jesuits formed their spiritual personae, so Jesuit art reflected, and had come to shape, this seminal idea in equal measure.

But for every stress on the logistics of place in the narrative, the Evangelicae historiae imagines also, intriguingly, marked the act of displacement that ensured the "composition of place" never unfolded as expected. ${ }^{159}$ In the Annunciation (Lk 1[:26-38]), it might be supposed that the descent from God the Father with the council of angels in the upper-left corner, deciding who would announce the incarnation (A); to the sending of Gabriel (B); to the transition from clouds to rays of light en route to the Virgin (C); would culminate in the person of Mary (fig. 2.17). ${ }^{160}$ Yet the eye is forced to digress and jump up to the wall of the rustic building (D), and it is the room ("Cubiculum") where the diagonal ends, well apart from the main point of the scene in the foreground: the entrance of the angel to inform Mary that she would be the Mother of Jesus (E). The location of the Virgin, in Loreto in the province of Ascoli Piceno ("quod visitur Laureti in agro / Piceno, vbi est Maria"), has superseded the main protagonist of the story, and a box, a stage setting of a furnished room, like an improbable biblical time machine, displays a vision from another time and place instead. Nicolas Standaert, s.J. has asserted that the disjunction of Mary's room caused by the digression in the approach allowed it to function as a sign of dislocation. ${ }^{161}$ It referenced both the concrete reality of her house in Loreto, itself miraculously re-placed and transported by angels from Nazareth according to a late thirteenth-century legend, and a tacit advocacy for how changes in place could stimulate a reorientation in spiritual outlook. Displacement did not have a scriptural foundation; the image was not so much derived from text as it provided an apocryphal exegesis based on lived experience, a by-product

\footnotetext{
$15^{8}$ Melion, "Quis non intelliget hoc voluissse Christum," 1-99.

159 Fabre, Ignace de Loyola, 163-92; 263-74; Standaert, "Composition of Place," 7-20.

160 Fabre, Ignace de Loyola, 265-74; Homann, Jerome Nadal, 1:103-13; Mauquoy-Hendrickx, Estampes des Wierix, 3, part 1:401, pl. 307, fig. 1991; Standaert, "Composition of Place," 14-16.

161 Standaert, "Composition of Place," 16.
}

FIGURE 2.17 Hieronymus Wierix, Annunciation, in Nadal, Adnotationes et meditationes in Evangelia, pl. 1, engraving (call no. LP 9.386 C RP). Brussels, Bibliothèque Royale de Belgique, Rare Books PHOTO: (C) BIBLIOTHÈQUE ROYALE DE BELGIQUE 


\section{$A N N V N C I A T I O$.}

Luc, $i$.

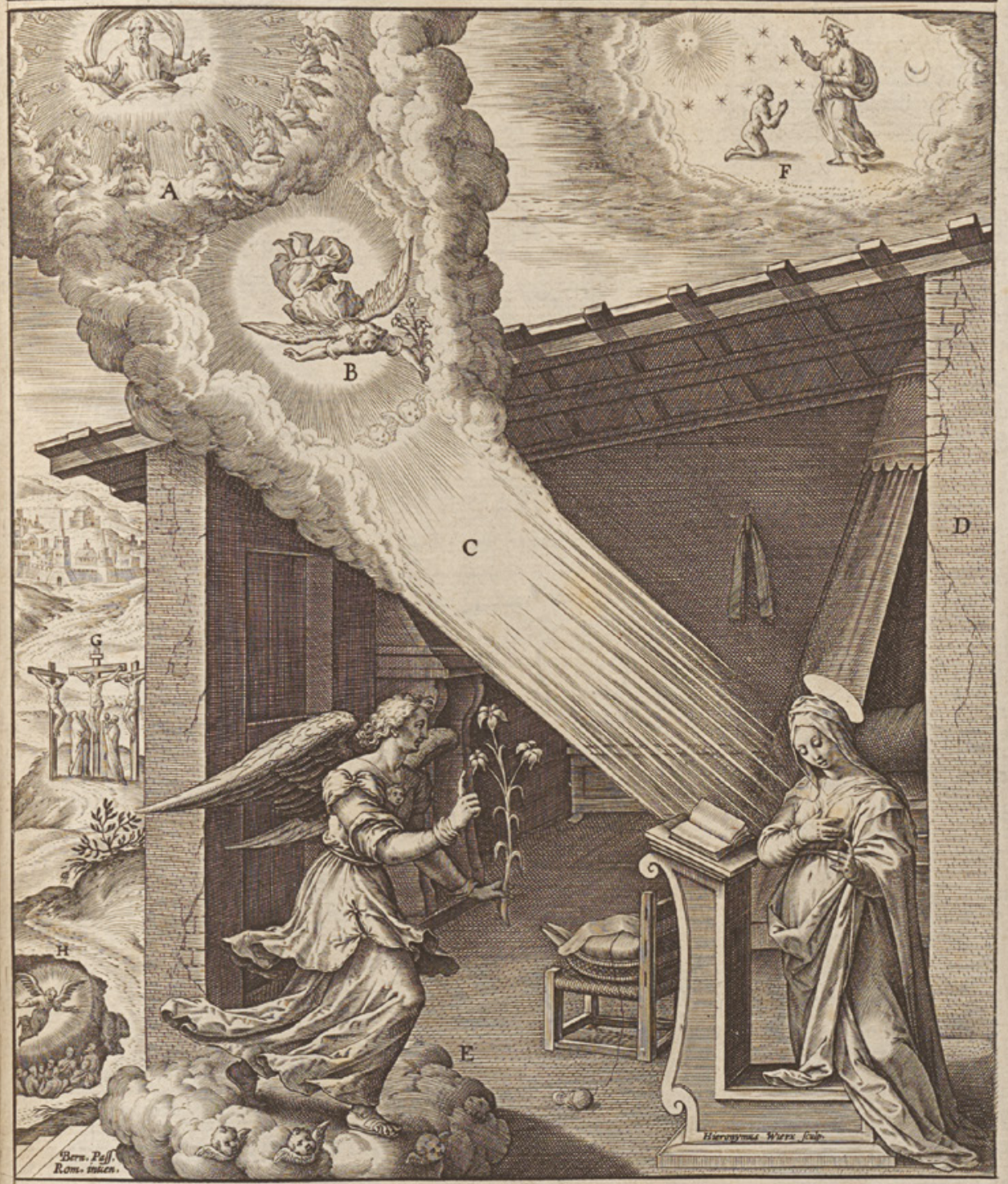

A. Comuentus Angelorum, vbi declarat Deus Incarnationem Chris ti, 0 defignatur Gabriel legatus .

B. Veriens Nazareth Gabriel, fibi ex aëre corpus accommodat.

C. Nubes ì calo, vide radi" ad Mariam Virginem pertinent.

D. Cubiculum, quod vifitur Laureti in agro Piceno, vbi eft Maria.

E. Ingreditur Angelus ad Mariam Virgi: nem; eam salutat; a sentitur Maria: fit Deus homo, 6 ' tosa Mater Dei.

F. Creatio hominis, quo die Deus factus eft homo.

G. Eadem dic Chris tus moritur, vt homo perditus recreetur.

H. Pie credi potes $t$, Angeham mifrum in Limbum, ad Christi incarnationem Patribus nunciandan. 
of the friction between the image as representation and the image as an expression of will, between the actual and the plausible. ${ }^{162}$ Another dislocation of the assumed trajectory then jarringly shifts the eye to the upper-right corner, so the three last letters return to the central subject by placing it in cosmic time: "F" paralleled the day of the creation of man with Christ's incarnation in the heavens above; "G" noted that the feast day of the annunciation (March 25) was the same day as the crucifixion in the hazy middle ground; and " $\mathrm{H}$," in the lower left of the picture, suggested that it was also the same day that saints of the Old Covenant stuck in limbo heard their redemption announced. This postscript guarded against the danger of projecting a personal account onto the Gospel narrative, displacing the ego to configure identity through its shifting counterpoint to place, a progression Standaert summed up as: "By a mental adoption of place, we are thus 'relocated' as persons."163

What makes the Annunciation one of the most pure distillations of the strategy of spatial dislocation in the Evangelicae, besides being the first image in the main body of the original edition, is its focus on an open room, with its side wall removed, as the dominant feature of the composition. ${ }^{164}$ The purpose of prayer in the Ignatian practice was to unlock a "third space," or room for spiritual encounter that defied the immutable earthly laws of time and space to unveil new opportunities. ${ }^{165}$ Place therefore also functioned as a limit, a fracturing of sight, like a horizon line, and to be "in place" meant to be engaged with the other of encounter. ${ }^{166}$ The Evangelicae was fundamentally premised on mental contact, not a bibliodrama or the psychology of the meditator, but instead the opportunity to interact with biblical figures that

162 Fabre, Ignace de Loyola, 246-62.

163 Standaert, "Composition of Place," 16.

164 Although the Annunciation was the first image in the Evangelicae historiae imagines, it did not begin the liturgical sequence of the Adnotationes et meditationes in Evangelia.

165 The Evangelicae historiae imagines is full of depictions of "third spaces" of encounter, lending a visual gloss to canonical biblical deeds, like The Descent of Christ into Hell, referenced in Zec 9[:11], Eccl/Sir 24[:45], and Eph 4[:9-10], where Christ appears in a cloudstrewn air pocket that permeates the plasma of the earth (Evangelicae historiae imagines, 131). The evolution of the design suggests this emphasis was intentional. Agresti's drawing of the subject represents a cross-section of the planet with striated bands of figures before reaching the devil at its center (Rome, Biblioteca Nazionale), and Passeri's version has merely streamlined the population and added a larger zone of solid earth between surface and core (Brussels, Bibliothèque Royale de Belgique). It is only in the final engraving that Christ received his own tunnel capsule, complete with a retinue of angels, that provides an actual "non-space" for meeting the viewer.

166 Fabre, Ignace de Loyola, 297-311. 
required a "third space" to facilitate the meeting. ${ }^{167}$ This was just as extreme a thought experiment then as it sounds today. In an era of reform, when issues of church authority were highly contentious, Jesuits premised contact with God on a dynamic, dialogic model. ${ }^{168}$ Where earlier spirituality, and the imagery it inspired, had by and large presented a preordained path, Nadal's Evangelicae historiae imagines acted as proxy for the viewer to determine his or her own approach to Christ, angels, and saints, instead of merely echoing the approved evangelical sources. ${ }^{169}$ The Evangelicae historiae imagines functioned as if the imitatio Christi (imitation of Christ) of the Spiritual Exercises had come to life. It was not so much about knowing episodes from the life of Christ, which had become a commonplace by this time, pictorially and textually. Rather, place and personhood were conjoined as cause and effect, for it was through the "composition of place" that the objective of the Spiritual Exercises, the individual's encounter with Jesus, was attained. ${ }^{170}$ Attention was focused not only on the spiritual identity of a Jesuit, but also on acquaintanceship with Jesus Christ, and it was this desire for a person-to-person relationship within a locus of encounter that shaped the identity of Jesuit art. ${ }^{171}$

The Evangelicae historiae imagines was therefore as much about place as its fertile negation, distilling an almost iconoclastic ambivalence to imagery into a quality more characteristic of Jesuit art-making than any single stylistic

167 Standaert, "Composition of Place," 14.

168 De Certeau, "Espace du désir ou le 'fondement' des Exercices spirituels," 126; de Certeau, "Space of Desire," 96.

169 An exceptional forerunner in this regard is Ludolph of Saxony's (c.1295-1378) Vita Christi (Life of Christ, c.1348-6o, first published in Cologne and Strasbourg: Arnold ter Hoernen, [c.1472] and Heinrich Eggestein, 1474), which has been discussed in the context of Ignatius's Spiritual Exercises, but not in terms of Nadal's works, although he too certainly would have been familiar with the text. Shore, "Vita Christi of Ludolph of Saxony," 1-32.

170 According to the Official Directory to the Spiritual Exercises (1599): "The composition of place is not the primary fruit of the meditation but only a way and an instrument toward it." (Official Directory 43:124). Fabre, Ignace de Loyola, 25-74, 121-62; Palmer, On Giving the Spiritual Exercises, 315; Standaert, "Composition of Place," 7-20.

171 The Directory to the Spiritual Exercises (c.1587) by Gil González Dávila (1532-96) explains that presence had two particular applications: (1) to allow a person to participate in the experience- - In the composition of place the exercitant should act as if present to the entire event." (Directory of González Dávila 31:93) and "In the composition of place, the one mediating should make himself present to the mystery as though it [were] being done for him alone" (Directory of González Dávila 31:161)—and (2) to situate the appearance of Jesus Christ in a singular temporal and geographic context. Fabre, Ignace de Loyola, 148-51; Standaert, "Composition of Place," 9-10. Palmer, On Giving the Spiritual Exercises, 251, 262. 
filter. ${ }^{172}$ That the Jesuit art of displacement was above all a mechanism of Catholic reform was in no small part due to Nadal's vision of the Society as a staunch rebuttal to Protestantism, as evinced by his linking of Ignatius's religious conversion with the excommunication of Martin Luther (1483-1546) by virtue of its occurrence in the same year $(1521) .{ }^{173}$ So it is hardly surprising that aspects of Jesuit art and architecture overlapped with the innovations of Protestant reform, seen in the adoption of their architectural precepts, like the preaching church, and the use of the tetragrammaton as an occasional textual citation of God in place of figural representation. ${ }^{174}$ Less expected, however, was a topographical organization that relied on the ostensibly contradictory principle of "no-place," or eu-topia, of the Foundation in the Spiritual Exercises that grounded place in the everywhere of world, which was, by definition, found to be nowhere. ${ }^{175}$ The early modern devotional image had been justified by the doctrine of the incarnation, which provided the rationale for the spiritual to assume substance, where Christ was held as a form-giving exemplum of Aristotelian entelechy (endelechia), perhaps no better template for the generation of a new order's art. ${ }^{176}$ But Jesuits perceived that the fall of man likewise caused the disruption of the place of Christ for person and picture, and it was this disjunctive arrangement that let repetition coexist with orientation by dislocation. In other words, the imitation of Christ was problematized and resolved as complementary modalities of the active and the contemplative life, deed and meditative instrument working in tandem. What Fabre has called a "melancholic attitude" ("attitude mélancolique"), founded on the composition of place as an exercise in the negation or dismantling of self, was the operative definition of a Jesuit aesthetic, one that used the complicated status of imagery in the post-Tridentine era to drive home the competing refractions of place, particularly in the admixture of discrete sites fostered by the mass dissemination of prints, in the construction of the self. ${ }^{177}$

What might be portrayed as the liminal borderland between image and world, where the logistics of printmaking and a revised pictorial poetics of

172 Fabre, Ignace de Loyola, 211-95.

173 John W. O'Malley, S.J., "The Imago: Context, Contents, and Controversy," in O'Malley, Art, Controversy, and the Jesuits, 11-49, here 32.

174 Mia M. Mochizuki, The Netherlandish Image after Iconoclasm, 1566-1672: Material Religion in the Dutch Golden Age (Aldershot: Ashgate, 2008), 126-62.

175 De Certeau, "Espace du désir ou le 'fondement' des Exercices spirituels," 119; de Certeau, "Space of Desire," 93; Fabre, Ignace de Loyola, 25-74.

176 Melion, "Art of Vision in Jerome Nadal's Adnotationes et meditationes in Evangelia," 71; Melion, "Christ as Subject and Source of Meditative Image-Making" and "Virtutis tacitate ut lumina non videant?," Meditative Art, 1-35, 37-104.

177 Fabre, Ignace de Loyola, 297-311; Fabre, "Dossiers bibliographiques," 467-68. 
place converged, created an ideal situation for the widespread copying of the Evangelicae historiae imagines. Thomas Buser cast Nadal's Evangelicae historiae imagines as a catalyst for Jesuit art in Rome, and quotations of the Evangelicae are easily charted, such as the frescoes for the Church of San Stefano Rotondo (with letters) by Niccolò Circignani (c.1517-c.1597), already in 1582, and the Basilica of San Vitale (without letters) by a follower of Paul Bril (c.1554-1626), around 1599 (fig. 2.18). ${ }^{178}$ Miguel Nicolau, S.J. has traced forty-six of the 160 anonymous engravings in the Vita D.N. Iesu Christi (Life of Our Lord Jesus Christ [Rome: Bartolomeo Zanetti, 16o7]) by Bartolomeo Ricci (1542-1613), novice master at Sant'Andrea a Monte Cavallo (later the site of Sant'Andrea al Quirinale) in Rome, to the plates from Nadal's Evangelicae historiae imagines, many of its images later appearing in an illustrated edition of the Spiritual Exercises published in Antwerp in 1640. ${ }^{179}$ The popularity of the Evangelicae for mission made it the single most popular print source to circulate among the Jesuit missions around the world, and the Society's efforts to cultivate a global audience with the "Biblia Natalis" resulted in the appearance of Nadal's imagery in Africa, East Asia, South Asia, and South America. ${ }^{180}$ In China, direct

${ }_{17} 8$ Other compositions indebted to Nadal can be seen in: Rome (Niccolò Circignani, for the Church of San Tommaso di Canterbury and the Church of Sant'Apollinare); Paris (Philippe de Champaigne, 1602-74, for the Church of Val-de-Grâce, Musée du Service de Santé des Armées); and Milan. Bailey, Between Renaissance and Baroque, 128-48, 153-65; Thomas Buser, "Jerome Nadal and Early Jesuit Art in Rome," Art Bulletin 58, no. 3 (1976): 424-33, here 427; Dekoninck, "Graphic Koiné for a New Religious Value," 285-86; Jean Michel Massing, "Jerome Nadal's Evangelicae historiae imagines and the Birth of Global Imagery," Journal of the Warburg and Courtauld Institutes 8o (2017): 169-84; Bert W. Meijer, ed., Northern Landscapes on Roman Walls: The Frescoes of Matthijs and Paul Bril, exh. cat. (Florence: Centro Di della Edifimi, 2003).

179 Dekoninck et al., Genèse, structure et postérité des Evangelicae historiae imagines; Fabre, "Exercices spirituels sont-ils illustrables?," 204-9; Nicolau, Jerónimo Nadal S.I. (1507-1580), $172-73$.

180 From the mission to China, Ricci would write in 16o5: "At this moment, this book [i.e., the Evangelicae historiae imagines] is more useful than the Bible itself," referring to the renowned Antwerp Polyglot Bible that had also been sent to China after being well received in India, and besides, "it [i.e., the Evangelicae historiae imagines] helps us to clarify, indeed to place before the eyes, what we cannot express with words." Henri Bernard-Maître, s.J., "Lart chrétien en Chine du temps du Père Matthieu Ricci," Revue d'histoire des missions 12 (June 1935): 199-229, here 217-20; Dekoninck, "Graphic Koiné for a New Religious Value," 277-78, 287-89; Dekoninck et al., Genèse, structure et postérité des Evangelicae historiae imagines; Jennes, Invloed der vlaamsche prentkunst in Indië, China en Japan tijdens de XVI en XVII eeuw, 30, 83-88, 110-15, 120, 142; Guy Lazure, "Nadal au Nouveau Monde: Une traduction poétique des Evangelicae historiae imagines, Pérou, vers 1614," in Emblemata sacra: rhétorique et herméneutique du discours sacré dans la littérature en images, ed. Ralph Dekoninck and Agnès Guiderdoni-Bruslé, Imago Figurata 


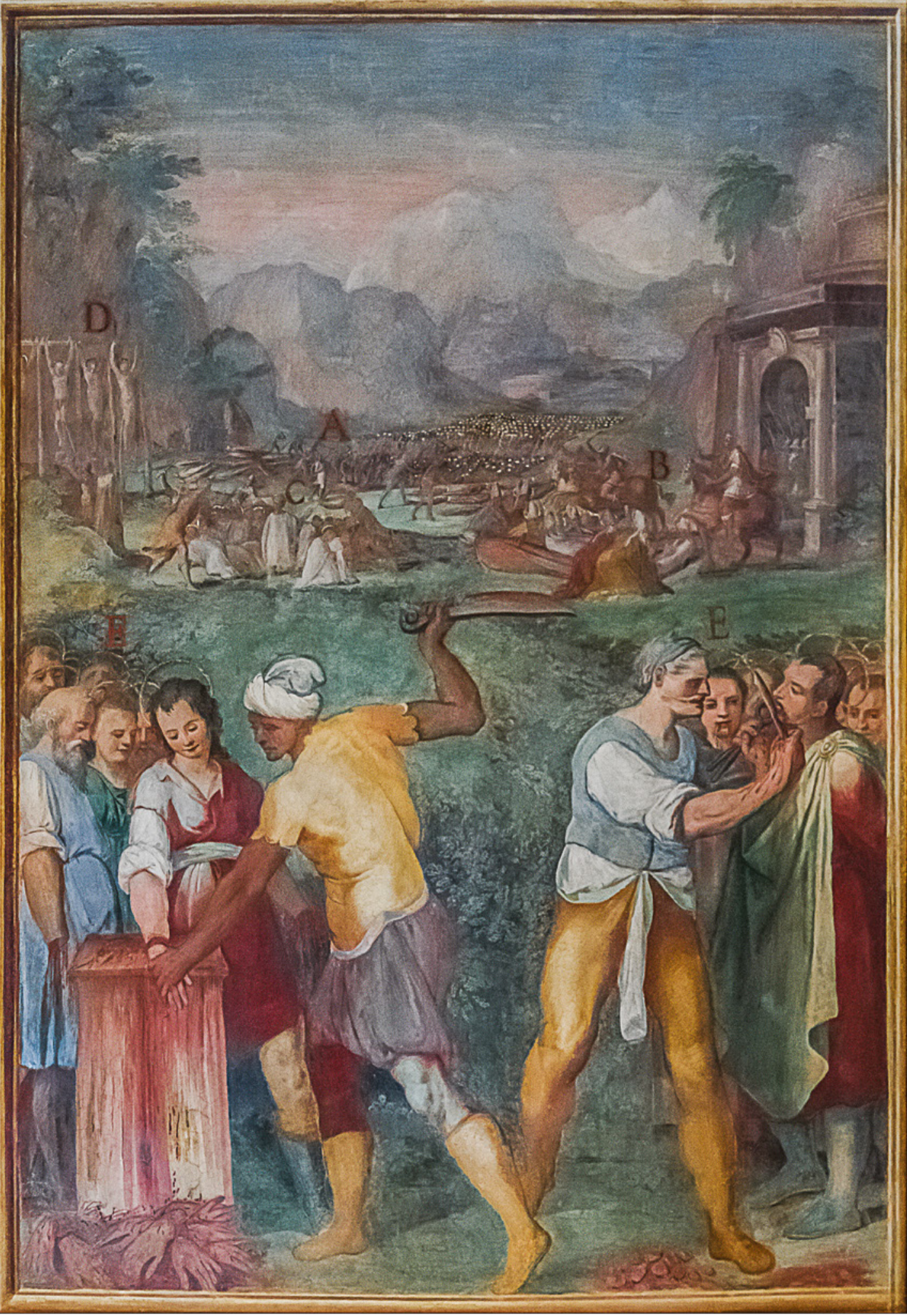


compositional borrowing was tweaked with local stylistic modifications, the Sinicized curls of cloud tumuli belying the western source of the annunciation scene for Giulio Aleni's (1582-1649) Tian zhu jiang sheng chu xiang jing jie (An illustrated history of the Lord of Heaven who became incarnate in the flesh [Jinjiang: Jing Jiao Tang, 1637]) (figs. 2.17, 2.19). ${ }^{181}$ Before the Evangelicae historiae imagines had been completed, it may already have been anticipated among such Jesuits in Japan as Marco Ferraro (1584-1628), who requested "un libro del P. Natale" (a book by Father Nadal) in a letter (October 25, 1587) six years before the book was first published. ${ }^{182}$ But as tempting as it may be to trace the

Studies 7 (Turnhout: Brepols, 2007), 321-31; Massing, "Jerome Nadal's Evangelicae historiae imagines and the Birth of Global Imagery," 184-220; Jacques Mercier, "Les sources iconographiques occidentales du cycle de la vie du Christ dans la peinture éthiopienne du dix-huitième siècle," Journal Asiatique 287, no. 2 (1999): 375-94.

181 The prints of the Evangelicae historiae imagines were used as pictorial models for at least three book projects in early modern China: fifteen woodblocks for João da Rocha's (15651623) Song nianzhu guicheng [The method of the rosary] (Nanjing: Society of Jesus, [c.161923]); approximately fifty-six woodcuts for Giulio Aleni's Tianzhu jiangsheng chuxiang jingjie; and forty-eight woodcuts for Johann Adam Schall von Bell's (1592-1666) Jincheng shuxiang [Images (of the life of Christ) in a booklet presented to his majesty] (Beijing: Society of Jesus, 1640). Niccolò Longobardo $\left(c .1559 / 65^{-1655}\right)$ was the first to request the Evangelicae for the China mission in a letter of October 18, 1598, where he explained how useful it would be for evangelization, and Lazzaro Cattaneo (1560-1640) asked for a copy in 1599. Bernard-Maître, "Art chrétien en Chine du temps du Père Matthieu Ricci," 217-20; Jennes, Invloed der vlaamsche prentkunst in Indië, China en Japan tijdens de XVI ${ }^{e}$ en XVII ${ }^{e}$ eeuw, 87; Massing, "Jerome Nadal's Evangelicae historiae imagines and the Birth of Global Imagery," 205-12; Mauquoy-Hendrickx, "Wierix illustrateurs de la Bible dite de Natalis," 6o-63; Rheinbay, Biblische Bilder für den inneren Weg, 329; Rheinbay, "Nadal's Religious Iconography Reinterpreted by Aleni for China," in "Scholar from the West": Giulio Aleni S.J. (1582-1649) and the Dialogue between Christianity and China, ed. Tiziana Lippiello and Roman Malek (Nettetal: Steyler Verlag, 1997), 323-34; Nicolas Standaert, S.J., "Chinese Prints and Their European Prototypes: Schall's Jincheng shuxiang," Print Quarterly 23 (2006): 231-53; Standaert, An Illustrated Life of Christ Presented to the Chinese Emperor: The History of the Jincheng shuxiang (1640) (Sankt Augustin: Institut Monumenta Serica, 2007).

182 Archivum Romanum Societatis Iesu (ARSI), Japonica-Sinica Collection (Jap. Sin.), 10-II, fols. $286^{\mathrm{r}-\mathrm{v}}$; Pasquale M. d'Elia, s.J., Le origini dell'arte cristiana cinese (1583-1640) (Rome: Reale Accademia d'Italia, 1939), 79, n. 4; Jennes, Invloed der vlaamsche prentkunst in Indië, China en Japan tijdens de XVI ${ }^{e}$ en XVII ${ }^{e}$ eeuw, 87; Rheinbay, Biblische Bilder für den inneren Weg, 326; Josef Franz Schütte, s.J., "Christliche Japanische Literatur, Bilder und Druckblätter in einem unbekannten Vatikanischen Codex aus dem Jahre 1591," Archivum historicum Societatis Iesu 9 (1940): 226-80, here 261.

$\leftarrow \quad$ FIGURE $2.18 \quad$ Niccolò Circignani, Martyrdom of Christians in Africa during the Reign of Hunneric, King of the Vandals (Fresco 29), 1582, fresco. Rome, Santo Stefano Rotondo

PHOTO: (C ZENO COLANTONI 


\section{報之氶降主上領母聖}

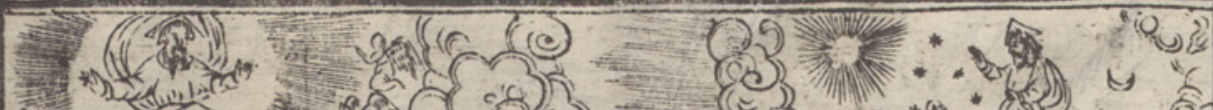
(9) if

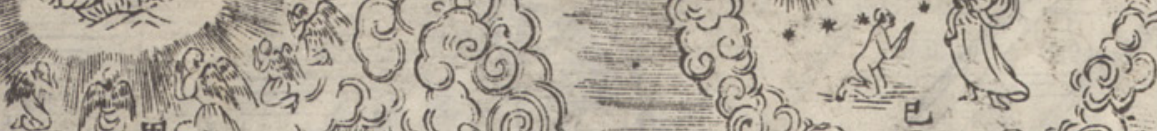

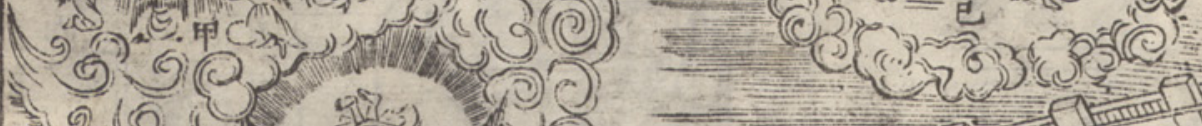

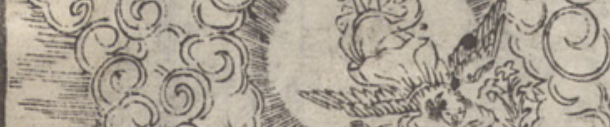

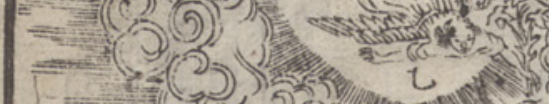

$=0$ (c) 3

(9) गोमियेय

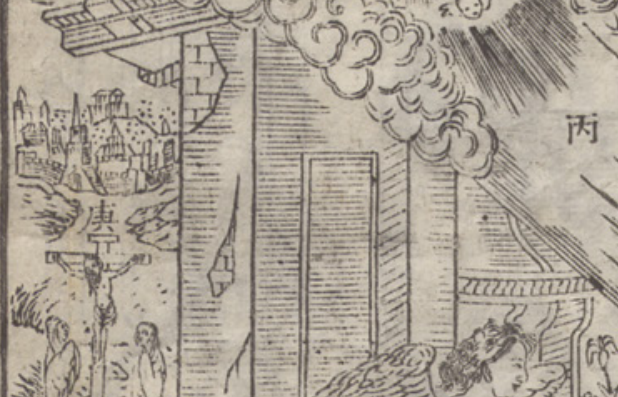

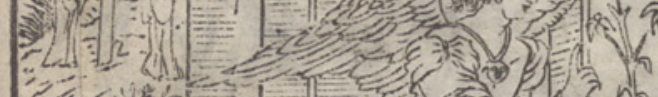
$=\frac{1}{2}=10$ m. 2.

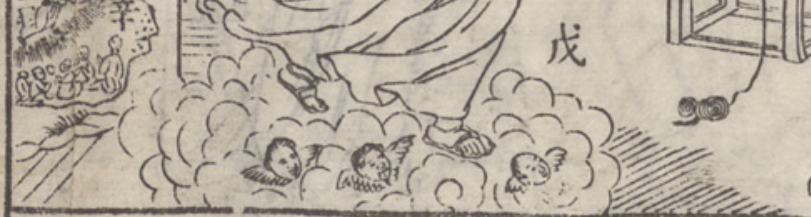
(1) $\left.4\right|_{(2)}$

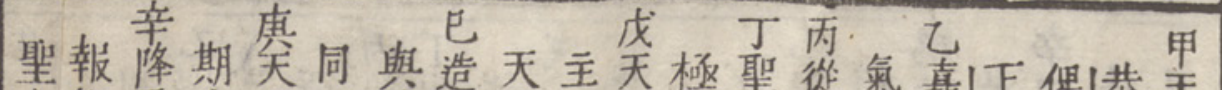

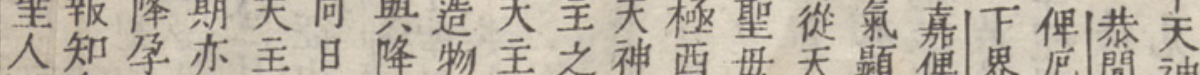

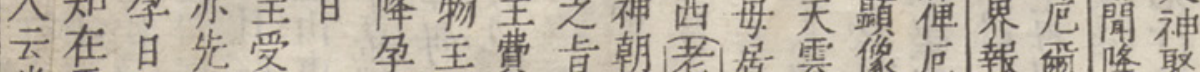

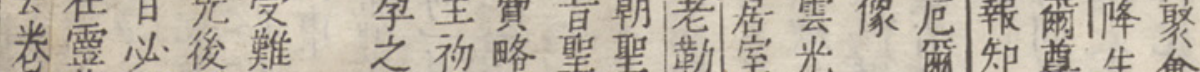

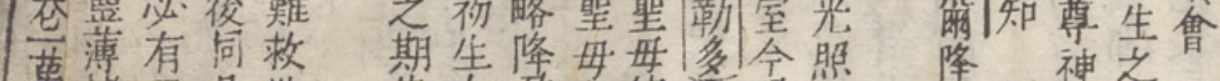

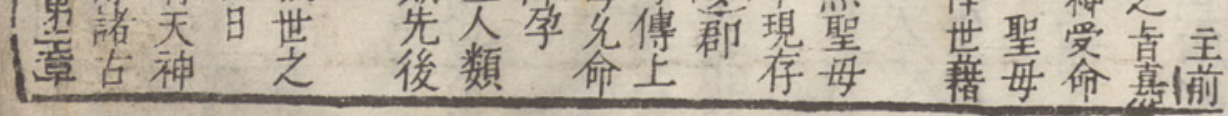


compositional progeny of the Evangelicae historiae imagines around the world, the consequences were much greater than literal tributes may imply. The caesurae of the Nadalian pattern opened the way for an extreme adaptability that made it an ideal paradigm for other art, as its absences revealed an unbounded capacity for pictorial ventures steeped in the permutations of place. ${ }^{183}$ Even a cursory overview of Jesuit art, as presented in "Part 1: Introduction," shows a definite preference for a locale-specific vocabulary, be it in a stylistic or a material idiom, that provided the right ratio of consistency to imagination, Gospel acts understood through a topographic lens ex libera meditatione. Nadal's recalibration of the coordinates of the image would undergird Jesuit art beneath its many surfaces and generate one of the Society's most consequential and nimble contributions to art history.

\subsection{The Imago primi saeculi Societatis Iesv}

There was a third book that significantly contributed to the systemization of a visual language for the Society of Jesus: the Imago primi saeculi Societatis Iesv, a collection of emblems to commemorate the first centennial of the Society of Jesus (fig. 2.20). ${ }^{184}$ It was the product of a collaboration led by the Jesuit provincial of Flanders, Jan De Tollenaere (1582-1643), under the principal editorship of Jean de Bolland (1596-1665), assisted by Godfried Henskens (1601-81), with the neo-Latinist poets Sidron de Hossche (1596-1630) and Jakob Van De Walle (1599-169o) contributing the text, and Cornelis I Galle (1576-1650) and the Rubens student Philippe Fruytiers (1610-66) executing the images. Like many of the Jesuit bestsellers, the Imago was published in Antwerp at the Plantin Press, and it was conceived as a luxury edition, priced at eighteen florins with an initial print run of 1,050 copies that sold out quickly. ${ }^{185}$ At $95^{2}$ folio-sized

183 For example: an early seventeenth-century edition of the Evangelicae historiae imagines in a Madrid private collection. Pierre Antoine Fabre, "Les 'manuscrits' de Madrid," in Dekoninck et al., Genèse, structure et postérité des Evangelicae historiae imagines.

184 For an introduction to the Imago primi saeculi Societatis Iesv, see Salviucci Insolera, Imago primi saeculi (1640) e il significato dellimmagine allegoria nella Compagnia di Gesù; Melion and Dekoninck, "Jesuit Illustrated Books," 535; O'Malley, Art, Controversy, and the Jesuits.

185 The Latin edition of the Imago primi saeculi Societatis Iesv required the investment of 18,900 florins for publication. It was distributed by book traders throughout Europe and many Jesuit houses purchased copies. In the jubileum year of 1640, the best pupils in each class of the Antwerp Jesuit School received copies as prizes. O'Malley, "Imago," 12, 17-18; Marc Van Vaeck, Toon Van Houdt, and Lien Roggen, "The Imago primi saeculi Societatis

$\leftarrow \quad$ FIGURE 2.19 Chinese Artist, Annunciation, in Giulio Aleni, Tian zhu jiang sheng chu xiang jing jie (Jinjiang: Jing Jiao Tang, 1637), fol. $6^{\mathrm{r}}$, woodcut (call no. Cod.sin. 23). Munich, Bayerische Staatsbibliothek PHOTO: () BAYERISCHE STAATSBIBLIOTHEK 


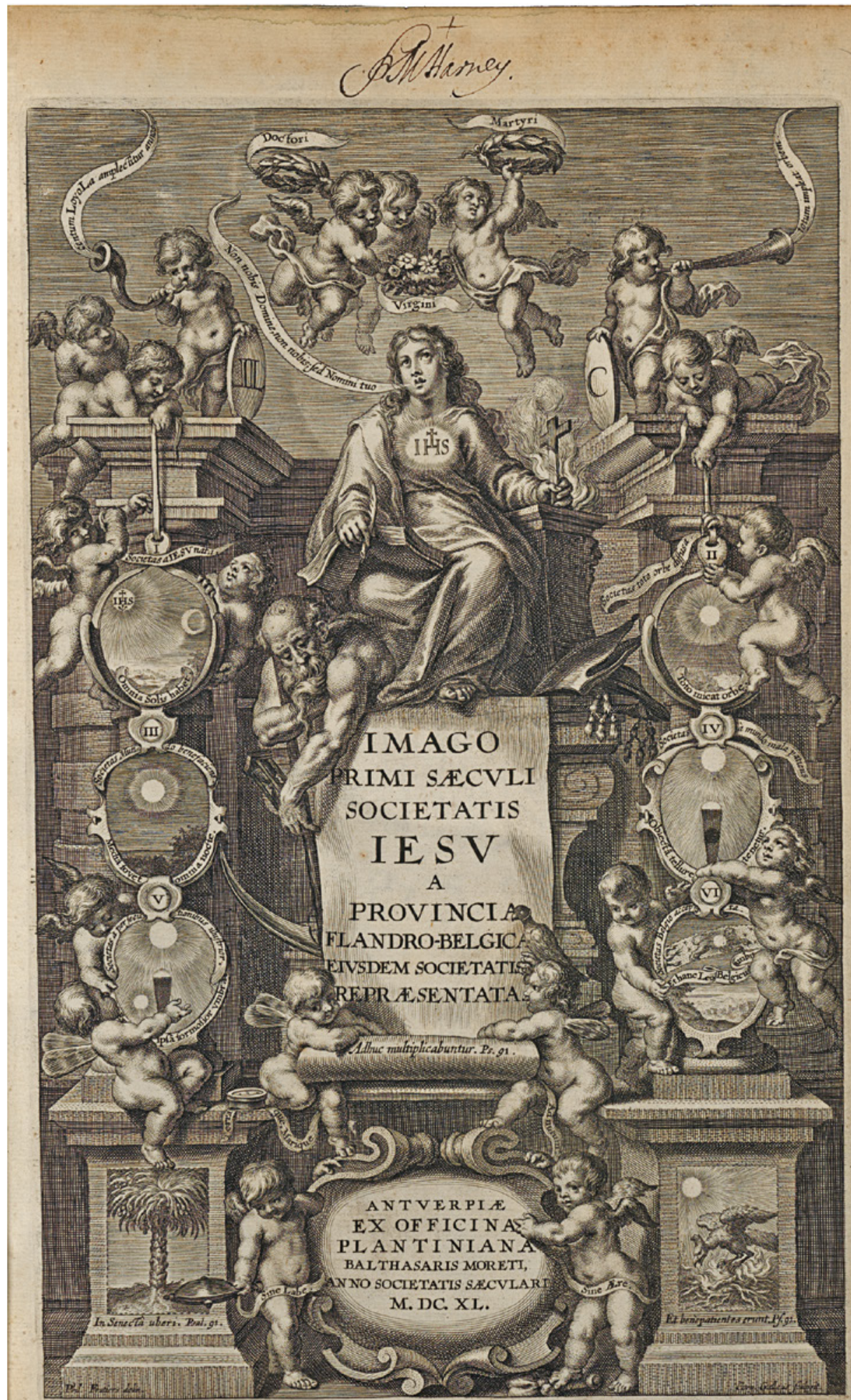


pages, encompassing 127 emblems, across two volumes, the book used prose and poetry, in Latin (124 poems), Greek (seven poems), and Hebrew (four poems), to explicate enigmatic imagery. ${ }^{186}$ And with numerous references to classical literature (Virgil, 7О BCE-19 B CE; Ovid, 43 BCE-17/18 CE; and Horace, 65 в use of cerebral puzzles, few books could match its lightly worn erudition or playful eloquence. Its six chapters ranged from the origins and development of the Society ("Societas nascens" and "Societas crescens," books 1 and 2); to Jesuit ministries and activities ("Societas agens," book 3); the order's adversity and suffering ("Societas patiens," book 4); its notable achievements and honored men in the vein of the ancient viri illustri ("Societas honorata," book 5); and a special section dedicated to the Flemish province ("Societas Flandro-Belgica," book 6), which comprised the two largest provinces of the Society, Flemish and Walloon, whose total number of 860 members in 1640 distinguished this

Iesu as Emblematic Self-presentation and Commitment," in O'Malley, Art, Controversy, and the Jesuits, 127-410, here 182 .

186 A Dutch edition-Af-beeldinghe van d'eerste eeuwe der Societeyt Iesu [Representation of the first century of the Society of Jesus] (Antwerp: Plantin Press under Balthasar Moretus, 1640)—a shorter (719 pages), quarto-sized volume with fewer emblems (104), was approved for publication on December 17, 1640 but only available for sale at the end of February 1641. It had a new Frontispiece designed by Abraham van Diepenbeeck (1596-1675) and engraved by Michel Natalis (1610-68), and was also printed by Balthasar I Moretus (1574-1641), this time for 13,725 florins. The Af-beeldinghe, translated by Laurens Uwens (1589-1641) (prose), and a promising student of Sidron de Hossche, Adriaen Poirters (1605-74) (poetry), constituted part of the Jesuit commitment to publishing quality editions in local languages, and it cost half the Latin version (nine florins) in a print run augmented by a third ( 1,525 copies). This edition relied less upon Greco-Roman mythology than on Dutch emblem books, such as those by Daniël Heins (1580-1655) and Jacob Cats (1577-1660). The resulting book did not provide a translation of the Latin so much as an independent, if related, interpretation. At the urging of Provincial Jan De Tollenaere, while the Dutch edition was still in production, Josse Andries (1588-1658) made two sets of comments (October 3, 1640 and January 13, 1641) on the Imago, with constructive suggestions for improvements "in the hope of a a French edition," which never came to fruition. Michael C.J. Putnam, Alexander Sens, and James P.M. Walsh, s.J., "Introductions to the Latin, Greek, and Hebrew Poetry," in O'Malley, Art, Controversy, and the Jesuits, 411-21; Van Vaeck, Van Houdt, and Roggen, "Imago primi saeculi Societatis Iesu as Emblematic Self-presentation and Commitment," $158,166-75$.

$\leftarrow \quad$ FIGURE 2.20 Frontispiece, in Jean de Bolland and Godfried Henskens, eds., Imago primi saeculi Societatis Iesv (Antwerp: Plantin Press under Balthasar Moretus, 1640), engraving (call no. vB 8.556 C). Brussels, Bibliothèque Royale de Belgique, Rare Books PHOTO: (C) BIBLIOTHÈQUE ROYALE DE BELGIQUE 
region as holding the largest number of Jesuits per square mile in the world. ${ }^{187}$ The Imago was not the first emblem book, the earliest religious emblem book, or the Society's pioneering emblem book. ${ }^{188}$ After Nadal's complex system of captions in the picture field, prominent early Jesuit emblem books must include the Flemish Jesuit Jan David's $\left(c .1545^{-1613)}\right.$ four emblem books (Antwerp: Plantin Press under Jan Moretus, 16oo-10) and the Roman Jesuit Sylvestro Pietrasanta's (1590-1647) De symbolis heroicis libri IX (Nine books of heroic symbols [Antwerp: Plantin Press under Balthasar Moretus, 1634]), whose 281 two-part heraldic devices would provide a basis for the Imago. 189 But as the most widely distributed of the Society's emblem books by Jesuits, for Jesuits, the Imago primi saeculi Societatis Iesv would become a critical agent in the production of Jesuit identity.

Image-making as a metaphor for Jesuit formation became the principal working analogy of their emblems, as suggested by the title of the Imago primi saeculi Societatis Iesv, the "image" of the Society of Jesus's first century of existence, when they numbered sixteen thousand men across forty provinces worldwide. ${ }^{190}$ Paul Begheyn, s.J. has noted that the word "emblem" derives from the ancient Greek en/bléma, literally "struck in," as in a scene, Persecutionis meritum, focused on the adversities that stamped Jesuits, where the hammering of an artisan's anvil is equated with formation in Christ's image: "The image of CHRIST, whom you follow as / leader, will glisten all the more, beaten out

187 O’Malley, "Imago," 14.

188 Emblems can be traced back to the Italian jurist Andrea Alciato's (1492-1550)Emblematum liber (Augsburg: Heinrich Steyner, 1531), which would appear in more than 150 editions, including several printed by the Plantin Press, the Imago's publishing house, beginning in 1565 . The first religious emblem book has been attributed to the poet Georgette de Montenay (1540-81), a French Calvinist (Huguenot) in Lyon, in her Emblemes ou devises chretiennes (Lyon: Jean Marcorelle, [c.1567-71], although the royal privilege dates to 1566). Paul Begheyn, S.J., "Emblem Books," in Worcester, Cambridge Encyclopedia of the Jesuits, 280-82, here 280; Enenkel, Invention of the Emblem Book; John W. O'Malley, S.J., "Introduction," in O'Malley, Art, Controversy, and the Jesuits, 1-10, here 3.

189 Jan David, Duodecim specula aliquando videre desideranti concinnata [Twelve mirrors arranged for one wishing now at last to see] (Antwerp: Plantin Press under Jan Moretus, 1610); David, Occasio arrepta, neglecta [Opportunity seized, shirked] (Antwerp: Plantin Press under Jan Moretus, 1605); David, Paradisus sponsi et sponsae [...] et Pancarpium Marianum [Paradise of the bridegroom and bride (...) and Marian garland] (Antwerp: Jan Moretus, 1607); David, Veridicus Christianus [True Christian] (Antwerp: Plantin Press under Jan Moretus, 16o1); Walter S. Melion, "Ut pictura lex: Jan David, s.J., on Natural Law and the Global Reach of Christian Images," in Göttler and Mochizuki, Nomadic Object, 149-86; Melion and Dekoninck, "Jesuit Illustrated Books," 527-29, 536; Salviucci Insolera, Imago primi saeculi (1640) e il significato dellimmagine allegoria nella Compagnia di Gesù, 107-41; Van Vaeck, Van Houdt, and Roggen, "Imago primi saeculi Societatis Iesu as Emblematic Self-presentation and Commitment," 127-99, esp. 133-46. 
with blows. / Nobler because of your wounds and your bloodshed, its / honor and value will increase from the iron itself." (fig. 2.21). ${ }^{191}$ An emblem consisted of at least a three-part format, from top to bottom: (1) the pictura, such as the picture of a blacksmith at work; (2) the motto, also called the inscriptio, which condensed the didactic point, as in "Blows bestow value" ("Dant pretium

\section{IMAGO PRIMI SÆCVLI SOC. IESV.}

\section{Perfecutionis meritum.}

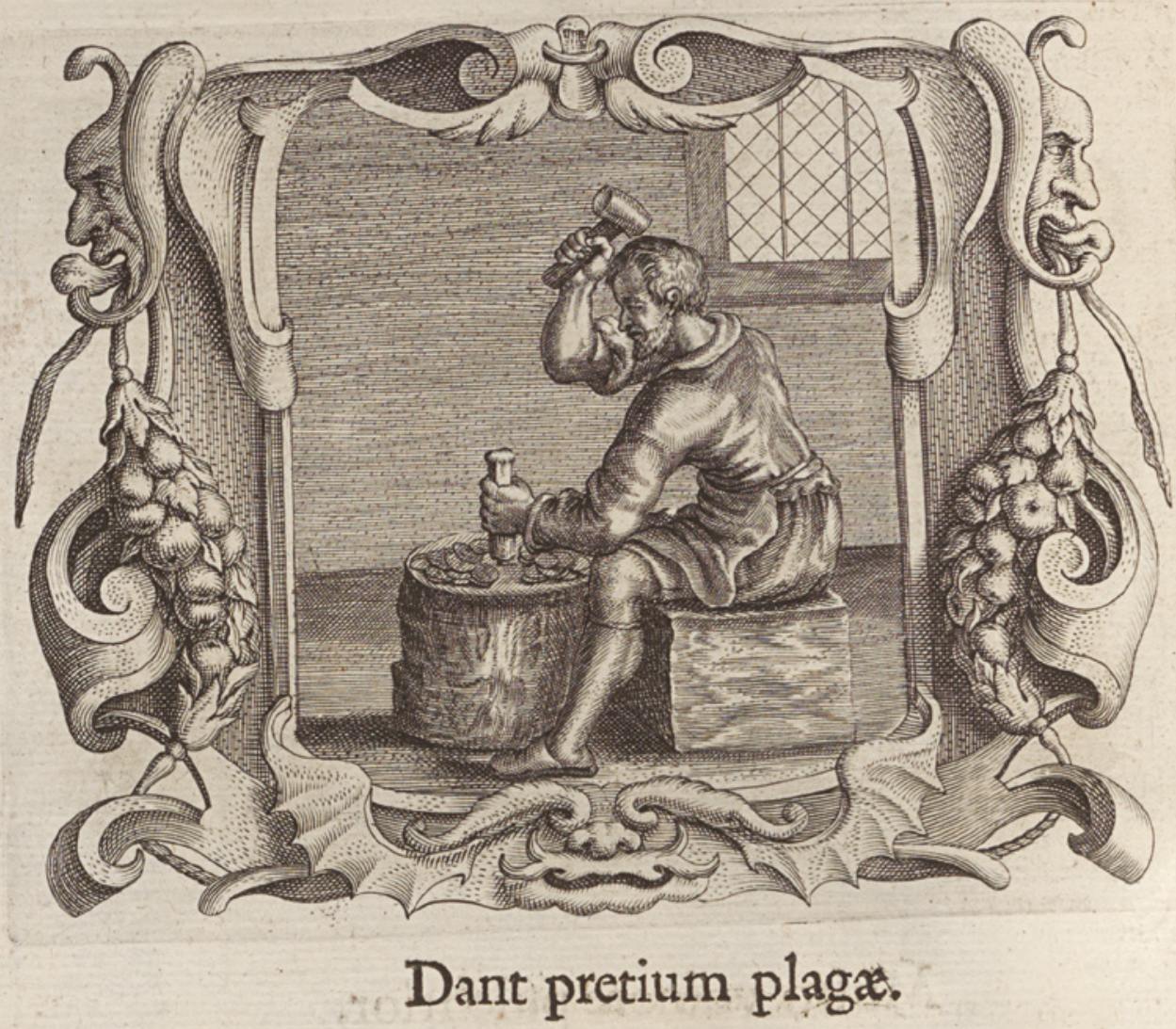

FIGURE 2.21 Cornelis Galle and Philippe Fruytiers, Persecutionis meritum, in de Bolland and Henskens, eds., Imago primi saeculi Societatis Iesv, 576, engraving (call no. vB 8.556 C). Brussels, Bibliothèque Royale de Belgique, Rare Books

PHOTO: (C) BIBLIOTHÈQUE ROYALE DE BELGIQUE

191 Begheyn, "Emblem Books," 28o; O’Malley, Art, Controversy, and the Jesuits, 616-17. 
plagae."), often drawn from proverbs, the Bible, and well-known classical texts; and (3) the subscriptio, or explanatory poem that amplified the weight of the picture through the art of memory, here located beneath the image proper, its lines opening with: "What fierce hurricanes weighted with insults thunder / in vain against the holy Companions of JESUS?" ("Qvid saeua frustrà detonat in sacros / IESV Sodales opprobriis grauis / Procella?"). ${ }^{192}$ The Imago emblems also included the less common feature of a fourth part, the titulus, or title at the top of the page, as in this case, "The Merit of Persecution" ("Persecutionis meritum.").

If a compound word-image system was already familiar from Nadal's Evangelicae historiae imagines, Imago subjects were no longer episodes from the Gospel, but synoptic allegories that disclosed why a Jesuit did what he did and how such actions molded his very being, turning this book into what O'Malley has characterized as "an elaborate catechism about paragons of Jesuit life."193 The workings of the emblem depended on the relationship between the parts of an image in the making of knowledge, as the Spiritual Exercises had done for contact between people, where the correct interpretation was situated in the links between phrase and picture, a very Ignatian approach with meaning harbored in interstices, shifting relations, and a "way of proceeding." Emblems might be supposed the most Jesuit of literary genre. ${ }^{194}$ It has been estimated that some 1,700 emblem books can

192 Peter M. Daly and G. Richard Dimler, S.J., The Jesuit Emblem in the European Context, Early Modern Catholicism and the Visual Arts Series 14 (Philadelphia: St. Joseph's University Press, 2016), 24; Ralph Dekoninck, "Jesuit Emblematics between Theory and Practice," in Maryks, Jesuit Historiography Online; http://dx.doi.org/10.1163/2468-7723_jho_COM _192540 (accessed March 15, 2021) [4-5]; Van Vaeck, Van Houdt, and Roggen, "Imago primi saeculi Societatis Iesu as Emblematic Self-presentation and Commitment," 196-98, which includes a glossary of emblem-related terms.

193 O'Malley, "Introduction," 4-5.

194 For an introduction to the early modern Jesuit emblem bibliography, see Begheyn, "Emblem Books," 280-82; de Boer, Enenkel, and Melion, Jesuit Image Theory; Pedro F. Campa and Peter M. Daly, eds., Emblematic Images \& Religious Texts: Studies in Honor of G. Richard Dimler, S.J., Early Modern Catholicism and the Visual Arts Series 2 (Philadelphia: St. Joseph's University Press, 2010); Chorpenning, Emblemata sacra; Peter M. Daly, The Emblem in Early Modern Europe: Contributions to the Theory of the Emblem (Farnham: Ashgate, 2014); Daly and Dimler, Jesuit Emblem in the European Context; Daly and Dimler, Corpus librorum emblematum: The Jesuit Series, 6 vols. (Montreal: McGill-Queen's University, 1997-present); Dekoninck, "Jesuit Emblematics between Theory and Practice"; Karl A.E. Enenkel, The Invention of the Emblem Book and the Transmission of Knowledge, ca.1510-1610 (Leiden: Brill, 2019); G. Richard Dimler, S.J., The Jesuit Emblem: A Bibliography of Secondary Literature with Select Commentary and Descriptions, AMs Studies in the 
be assigned to early modern Jesuit authors, of which the Flemish province produced one-fifth, so members of the Society were responsible for thirtyfour percent of all emblem books in the early modern period, and as a single group composed more than all other Catholic religious orders combined. ${ }^{195}$ In the hands of Jesuits, what began as a spiritually grounded system of representation flourished into a requisite aid for one of its premier ministries, the humanist pedagogy of the Jesuit educational system, the Ratio studiorum, that placed great value on sacra eloquentia, or eloquent rhetoric in the service of sacred causes, and consequently the practice of emblem exhibitions, or affixiones, in Jesuit colleges. ${ }^{196}$ Jesuit emblem books also enjoyed great popularity in society at large, as the case of the German Jesuit Jeremias Drexel (1581-1638) suggests: between 1618 and 1642, 170, ooo copies of Drexel's twelve emblem books were sold by his three Munich publishers when the city had only twenty-two thousand inhabitants. ${ }^{197}$

Emblem 19 (New York: AMs Press, 2005); G. Richard Dimler, S.J., Studies in the Jesuit Emblem, AMs Studies in the Emblem 18 (New York: AMs Press, 2007); Salviucci Insolera, Imago primi saeculi (1640) e il significato dell'immagine allegoria nella Compagnia di Gesù, 1-58; John Manning and Marc Van Vaeck, eds., The Jesuits and the Emblem Tradition: Selected Papers of the Leuven International Emblem Conference 18-23 August 1996, Imago Figurata Studies 1A (Turnhout: Brepols, 1999); Melion and Dekoninck, "Jesuit Illustrated Books," 527-37; O'Malley, Art, Controversy, and the Jesuits; Karel Porteman, Inleiding tot de Nederlandse emblemataliteratuur (Groningen: Wolters-Noordhoff, 1977); Mario Praz, Studies in Seventeenth-Century Imagery (Rome: Edizioni di Storia e Letteratura, 1964), 134-69; Anne-Elisabeth Spica, "Les jésuites et l'emblématique," XVII e siècle 237 (2007): 633-51; Spica, Symbolique humaniste et emblématique: L'évolution et les genres (1580-1700) (Paris: Champion, 1996).

195 O'Malley has observed that of the 1,700 emblem books, five hundred were first editions, and the rest were reprints, translations, or subsequent editions. Peter Daly and Richard Dimler, S.J. (1931-2020) have traced a total of at least 1,514 Jesuit titles in Latin and a number of modern European languages. Dekoninck has calculated the striking statistic that just five percent of the Society of Jesus produced twenty-six percent of all emblem books in the seventeenth and eighteenth centuries. Daly and Dimler, Corpus librorum emblematum; Dekoninck, "Jesuit Emblematics between Theory and Practice," [3]; Melion and Dekoninck, "Jesuit Illustrated Books," 527; O’Malley, "Introduction," 3.

196 Dekoninck, "Jesuit Emblematics between Theory and Practice," [8-10]; Fumaroli, Âge de l'éloquence; Lukács, Ratio atque institutio studiorum Societatis Iesu (1586, 1591, 1599); Karel Porteman, "The Use of the Visual in Classical Jesuit Teaching and Education," Paedagogica historica 36, no. 1 (2000): 179-96; Porteman, Emblematic Exhibitions (Affixiones) at the Brussels Jesuit College (1630-1685): A Study of the Commemorative Manuscripts (Royal Library, Brussels) (Brussels: Royal Library, 1996); Van Vaeck, Van Houdt, and Roggen, "Imago primi saeculi Societatis Iesu as Emblematic Self-presentation and Commitment," 160-63. O’Malley, "Introduction," 3. 
The Frontispiece of the Imago primi saeculi Societatis Iesv set the tone with its lively band of assorted putti, laurel wreaths aloft, horns blazing, and banderoles flying around the architectural scaffolding in a stirring performance of the Aristotelian epideictic ceremonial oratory (fig. 2.20). Two themes defined the Imago's repercussions for the visual shaping of Jesuit identity, established by the subsidiary scenes found in its six cartouches and two column pedestals. The first and dominant theme underscored the limitless range of the Society of Jesus, where the world operated as both origin and objective. ${ }^{198}$ The sun, moon, and earth circumscribed the transmission of the Jesuit message around the earth via light and sound in the framing text of at least the first four vignettes (and debatably all the pictorial scenes) and the putto with the trumpet in the upper-right corner. ${ }^{199}$ Where the Spiritual Exercises highlighted the life-changing moment of self-discovery grounded in the world, and Nadal's Evangelicae historiae imagines used the juxtaposition of word and image to focus on the push and pull between place and non-place in encounter with the other, the Imago expressed the centrality of topography through the cosmic dimensions of divine omnipresence. Its first emblem, Societas Iesv, defined the Society of Jesus as the sun whose rays nurture the earth, from the motto, "There Is No Person Who Might Hide Himself from His Warmth, Psalm 18[:7]" "Non est qui se abscondat à calore eius. Psal. 18."), to the last lines of its poem, which renewed the charge famously attributed to St. Ignatius as the exhortation he favored in the closing of his letters to "go forth and set the world on fire" ("Ite inflammate omnia."): "What the rays of the Sun do, / the Company of JESUS also accomplishes. All the earth / where it stretches far and wide is set aflame by it" (fig. 2.22). ${ }^{200}$ Later, in the emblem Societatis Iesv propagatio, a candle shining brightly in a landscape was

198 Salviucci Insolera, L'imago primi saeculi (1640) e il significato dell'immagine allegoria nella Compagnia di Gesù, 109-14; Michael C.J. Putnam, "The Frontispiece and Opening Emblem of the Imago: A Translation," in O'Malley, Art, Controversy, and the Jesuits, 50-55, here 50-54.

199 Cartouche 1 for book 1 on the origins of the Society is presented as "The Society born of JESUS possesses everything of the Sun" ("Societas a IESV nata / Omnia Solis habet."); Cartouche 2 for book 2 on the development of the Society is understood as "The Society spread throughout the whole world, gleams throughout the world" "Societas toto orbe diffusa / Toto micat orbe."); Cartouche 3 for book 3 on the ministries of the Society is framed as "The Society doing good to the world fosters all things from night's midst" ("Societas Mundo benefaciens / Media fovet omnia a nocte."); Cartouche 4 for book 4 on the adversity faced by the Society is conceived as "The Society suffering evils from the world is positioned with the earth thrust in between" ("Societas à mundo mala patiens / Obiectâ tellure tenetur."); and the banderole from the putto with the trumpet in the upper-right corner reads, "Let it fill the whole world" ("Totum impleat orbem."). Putnam, "Frontispiece and Opening Emblem of the Imago," 53-54.

200 Ps 18:7: "Then the earth reeled and rocked; / the foundations also of the mountains trembled / and quaked, because he was angry." O'Malley, Art, Controversy, and the Jesuits, $424-25$. 


\section{PROLEGOMENA DE ANNO SECVLARI. 43}

\section{Societas IES v.}

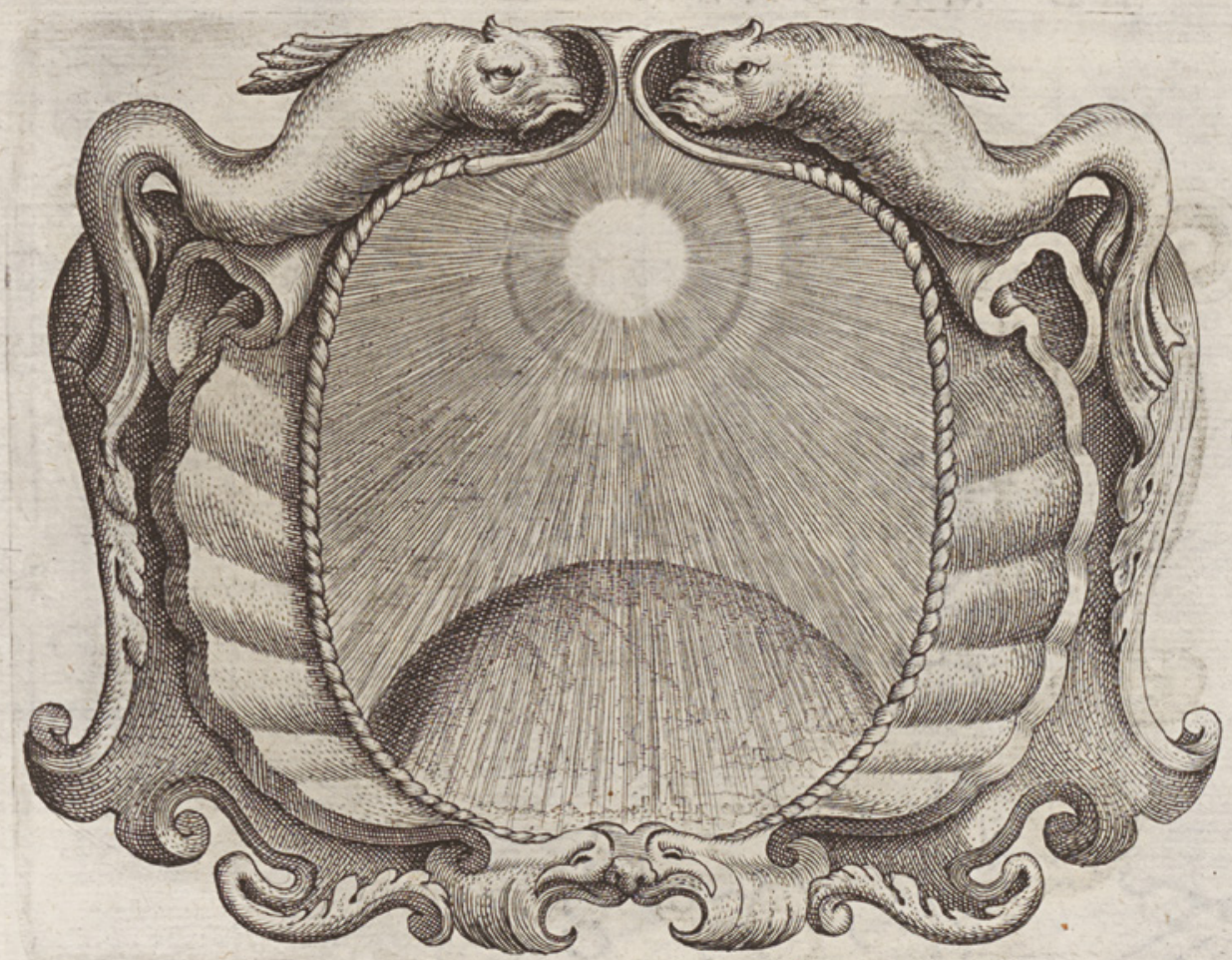

\section{Non eft qui fe abfcondat à calore eius. P fal.is.}

FIGURE 2.22 Cornelis Galle and Philippe Fruytiers, Societas Iesv, in de Bolland and Henskens, eds., Imago primi saeculi Societatis Iesv, 43, engraving (call no. vB 8.556 C). Brussels, Bibliothèque Royale de Belgique, Rare Books PHOTO: ( BIBLIOTHÈQUE ROYALE DE BELGIQUE

equated with the Society enlightening the world: "The Spread of the Society of Jesus. / Where once it is lit, it will then and there fill the world with light" ("Societatis Iesv propagatio. / Vt semel accensa est, simul implet luminis orbem.") (fig. 2.23). ${ }^{201}$ The sun, the earth, the candle, the wooded landscape were all part

201 O'Malley, Art, Controversy, and the Jesuits, 506-7. 


\section{IIBER SECVNDVS. SOCIETAS CRESCENS, $3 I 7$}

\section{Societatis I E SV propagatio.}

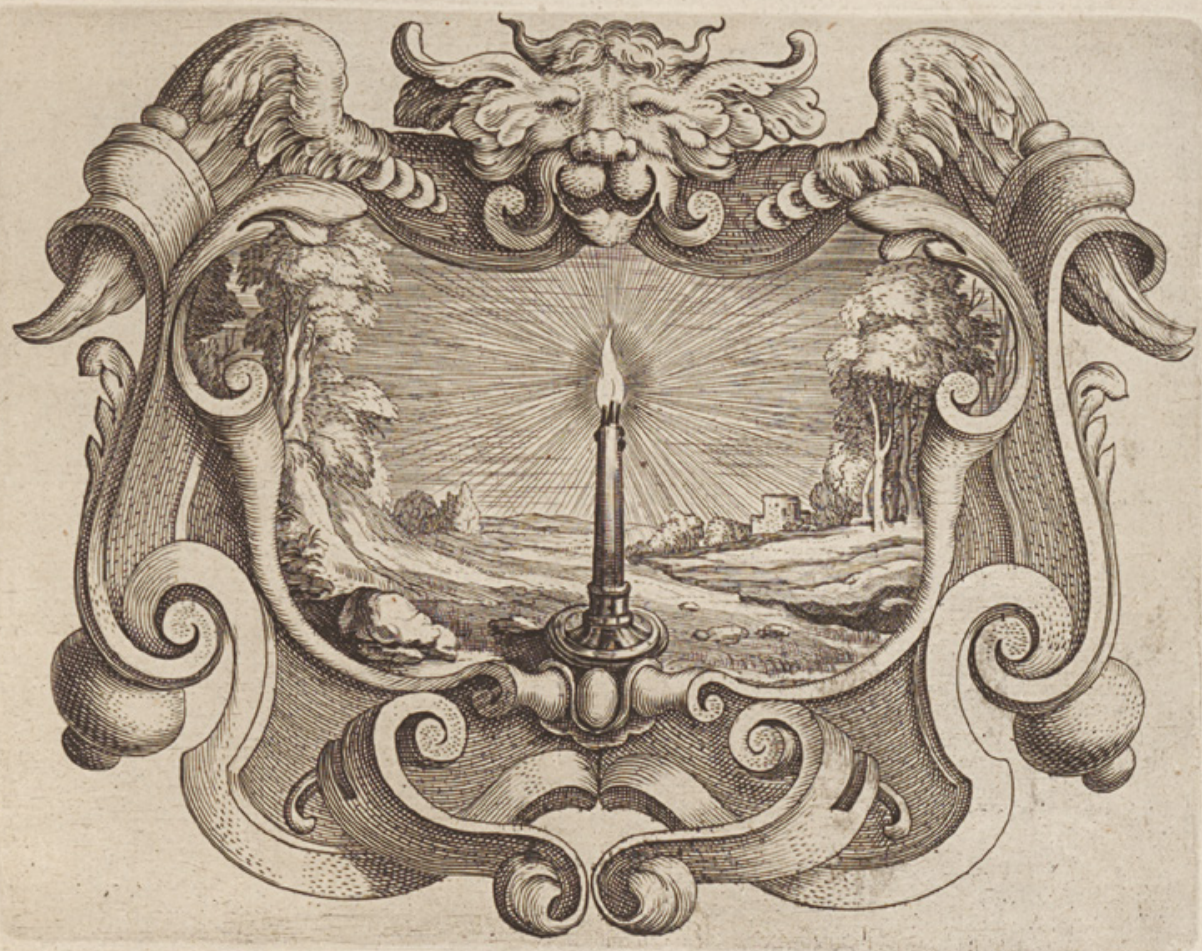

\section{Vt femel accenfa eft, fimul implet luminis orbem.}

FIGURE 2.23 Cornelis Galle and Philippe Fruytiers, Societatis Iesv propagatio, in de Bolland and Henskens, eds., Imago primi saeculi Societatis Iesv, 317, engraving (call no. vв 8.556 C). Brussels, Bibliothèque Royale de Belgique, Rare Books PHOTO: (C) BIBLIOTHÈQUE ROYALE DE BELGIQUE

of the "similitude of real things" in a world-affirming spirituality, the visible signs of the "sacrament of the invisible" that registered the emblem book as liber mundi, again the vita contemplativa (contemplative life) inextricable from 
the vita activa (active life), all ideas introduced by Ignatius and spread by Nadal that invited an emblematic reading of the world. ${ }^{202}$

Yet the Imago primi saeculi Societatis Iesv was not simply the conclusion of a world perspective. The Society nurtured the global ambitions of the postTridentine Roman Catholic Church, and the Imago presented the enlargement to a world arena as an antidote to Protestantism and a pledge to propel Catholicism's triumph as a universal faith into the future. ${ }^{203}$ Two globes, East and West, appear paired twice in a pictorial language that was expressly providential and mission-oriented. The first time follows the candle emblem, reassuring readers that the worldwide presence of the Society of Jesus fulfills the prophecy of the messenger Malachi ("Societas Iesv toto orbe diffusa implet prophetiam Malachiae."). ${ }^{204}$ The second occurrence arrives several pages afterward, in the emblem Societatis Missiones Indicae, under the auspices of the Society's mission to India, which occupied the half-way point on voyages between the two hemispheres (fig. 2.24). The motto reads: "One world is not enough" ("Vnus non sufficit orbis."), the oft-repeated rallying cry for missionary ministry that invoked a Christian humanist representation of western exploration to remind readers that the "standards of JESUS" ("signa IESV")—whose language conjured up the spiritual armor of "The Contemplation of the Kingdom of Christ" during the second week of the Spiritual Exercises (Spiritual Exercises, v. 91-99) and the fourth day of "Meditation on the Two Standards" (Spiritual Exercises, v. ${ }^{136-48)}$ — prevailed over the banners of any temporal leader past or present. ${ }^{205}$

202 Dekoninck, Ad imaginem, 19-35; Dekoninck, "Jesuit Emblematics between Theory and Practice," [3-4]; Van Vaeck, Van Houdt, and Roggen, "Imago primi saeculi Societatis Iesu as Emblematic Self-presentation and Commitment," 128.

203 O’Malley, "Imago," 32.

204 O'Malley, Art, Controversy, and the Jesuits, 508-9.

205 "Vnus non sufficit orbis" recalled the devout pledge chosen by King Philip II of Spain (1527-98, r.1556-98), "non sufficit orbis" (the world is not enough). The emblem's poem cited the Pillars of Hercules at the Straits of Gibraltar, the subject of the next image (Imago primi saeculi Societatis Iesv, 327) and the symbolic demarcation of the end of the known world, after the motto that Philip II's father, the Holy Roman emperor and king of Spain Charles v (1500-58, r.1519-56) had assumed of "plus ultra" (farther beyond), following the discovery of the New World by Christopher Columbus (1451-1506). It also reminded, "Thus once upon a time the world was not equal to the youth of AEmathia" ("Sic quondam AEmathio iuveni par non fuit orbis."), a citation to Emathia, the district of Macedonia where Alexander the Great (356-23 BCE), the legendary military conqueror of the ancient world, was born. At the time, it was thought that the epitaph of Alexander's tomb stated: "A tomb now suffices for him for whom the world was not enough," an idea expressed in Juvenal's $\left(c .55^{-c .127}\right.$ CE) Satura X (Satire X, c.12O CE): 
326 IMAGO PRIMI SRCVLI SOC. IESV. Societatis Miffiones Indica.

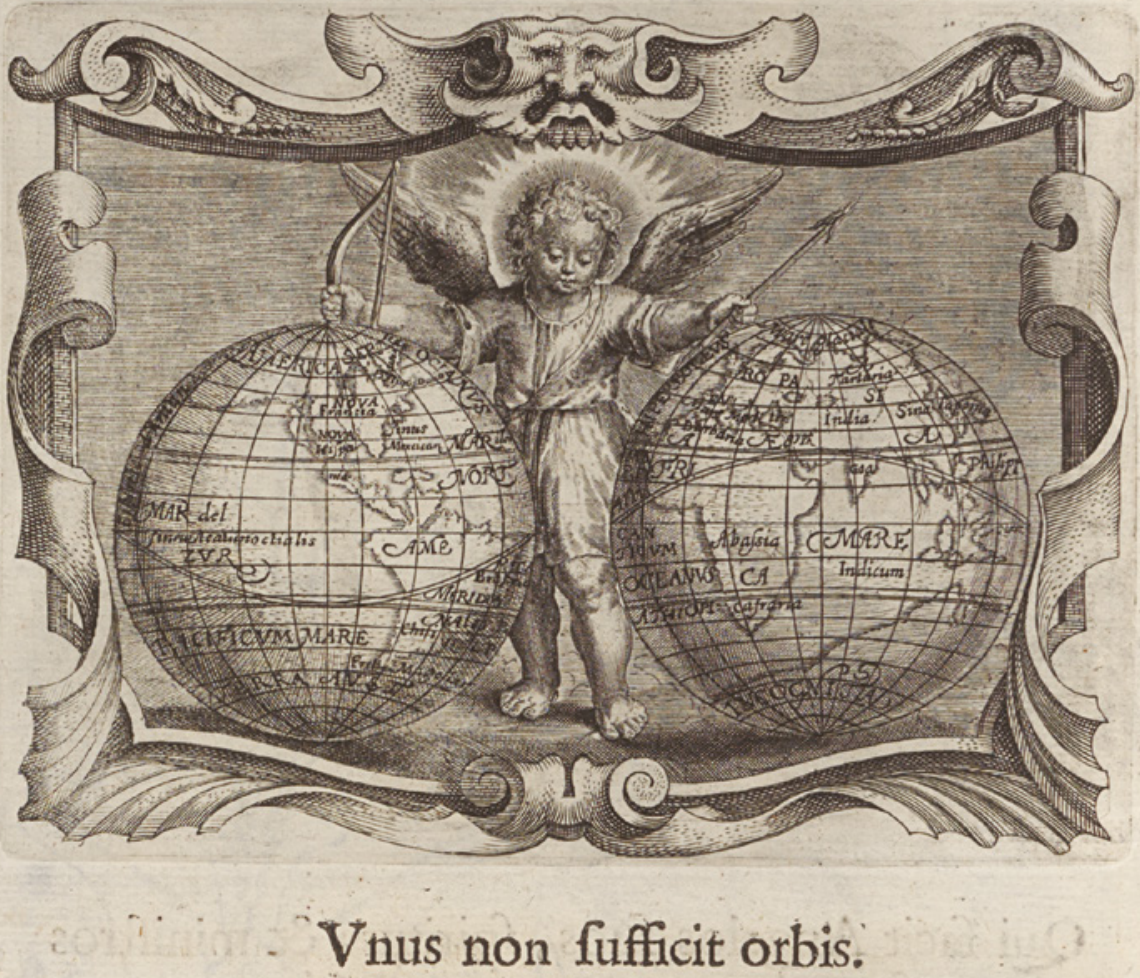

FIGURE 2.24 Cornelis Galle and Philippe Fruytiers, Societatis Missiones Indicae, in de Bolland and Henskens, eds., Imago primi saeculi Societatis Iesv, 326, engraving (call no. vв 8.556 C). Brussels, Bibliothèque Royale de Belgique, Rare Books PHOTO: (C) BIBLIOTHÈQUE ROYALE DE BELGIQUE

One world is not enough for the young man from Pella. ["Unus Pellaeo iuveni non sufficit orbis;"]

In discontent he seethes at the narrow limits of the universe as if confined on the rocks of Gyara or tiny Seriphus.

But once he has entered the city that is fortified by potters, his coffin will be big enough. It is only death that reveals the miniscule size of human bodies.

Susanna Morton Braund, ed. and trans., Juvenal and Persius, Loeb Classical Library 91 (Cambridge, MA: Harvard University Press, 2004), 380-81, satire 10, lines 168-73; Fleming, Draw Me into Your Friendship, 82-89, 110-15; Ganss, Spiritual Exercises of Saint Ignatius, 53-55, 65-67; O'Malley, Art, Controversy, and the Jesuits, 524-25, 69o-91, nn. 273, 277; Earl 
The Imago's pictures resulted from a search for a cosmic symbolism that would require the creation of a redesigned iconography and then expand far beyond it. At the time, the emblem was viewed as the quintessential form of argumentation for its emphasis on alacritas (vivacity, cleverness, enthusiasm), which touched upon factors of novitas (novelty), admiratio (wonder), and resourceful invention, especially when combined with the two pillars of rhetoric, copia (abundance, amplification) and varietas (variety, variation, variegation), that drew upon a series of unusual metaphors to capture attention and ensure a memorable message. ${ }^{206}$ Jesuit emblem books, like the Imago, celebrated the role of human ingenuity in making a message sympathetic, the symbolic image as the touchstone of oratorical prowess. Marc Fumaroli (1932-2020) has identified the Imago as the apex of a Jesuit "Asian" rhetorical style, in the classical categories, with its facility for dazzling displays of verbal pyrotechnics and exuberant abundance, over the sober, understated logic of the "Attic" school. 207 This flair for the virtuoso effect was vital to Tridentine efforts to win back the public imagination and would later be grafted onto the distinction between the baroque and classicism. But importantly, for Jesuits, it oriented picturing to geography, where the many places and races encountered around the world beckoned propitiously.

For the anticipated outcome of the world as goal was also noted in the Frontispiece of the Imago primi saeculi Societatis Iesv, and its second theme, the fruitful palm tree, imparts the legacy of the Society of Jesus for art (fig. 2.20). ${ }^{208}$ To Jesuits, this Mediterranean tree signaled their efforts to promote Roman Catholicism as a worldwide faith, in line with the message of Psalm 91:15 below the Frontispiece palm tree that runs across the bases of the left column ("In bountiful old age. Psalm 91.," "In senectâ uberi. Psal. 91."); the central scroll ("They will yet be multiplied. Psalm 91.," "Adhuc multiplicabuntur. Ps. 91."); and

Rosenthal, "The Invention of the Columnar Device of Emperor Charles V at the Court of Burgundy in Flanders in 1516," Journal of the Warburg and Courtauld Institutes 36 (1973): 198-230; Rosenthal, "Plus ultra, Non plus ultra, and the Columnar Device of Emperor Charles V," Journal of the Warburg and Courtauld Institutes 34 (1971): 204-28.

206 Dekoninck, "Jesuit Emblematics between Theory and Practice," [7, 9]; Marc Fumaroli, "Baroque et classicisme: L'Imago primi saeculi Societatis Iesu (1640) et ses adversaires," Lécole du silence: Le sentiment des images au XVII e siècle (Paris: Flammarion, 1998), 44576, 635-40; Marc Fumaroli, "Classicism and the Baroque: The Imago primi saeculi and Its Detractors," trans. Paul J. Young, in O'Malley, Art, Controversy, and the Jesuits, 57-88.

207 Fumaroli has traced Attic/Asian rhetorical distinctions back to Cicero's Brutus: De claris oratoribus (Brutus: On Famous Orators, c.46 вСЕ) and the Orator (Orator, 46 вСЕ), where they originated in the contrast between Doric Greek and ancient Ionian cultures. Fumaroli, Âge de l'éloquence; Fumaroli, "Baroque et classicisme," 445-49, 635-36; Fumaroli, "Classicism and the Baroque," 57-59; Salviucci Insolera, L'imago primi saeculi (1640) e il significato dell'immagine allegoria nella Compagnia di Gesù, 193-219.

208 O'Malley, Art, Controversy, and the Jesuits, 506-7. 
the right column ("And they will be well-enduring. Psalm 91.," "Et benepatientes erunt. Ps. 91."). ${ }^{209}$ That the Society envisioned its impact in explicitly global terms was already clarified in an opening emblem, the Societas anno saeculari copoiosos fructus promittit, complete with the repetition of the palm tree motif and a reference to the same Psalm- "The Society Gives Assurance of Bounteous Produce in Its Centenary Year. / In bountiful old age. Psalm 91[:15]" ("Societas anno saeculari copiosos fructus promittit. / In senectâ vberi. Psal. 91.")—where its pendant poem explains (fig. 2.25):

\section{, 50 IMAGO PRIMI SECVLI SOC. IESV. \\ Societas anno freculari copiofos fructus promittit.}

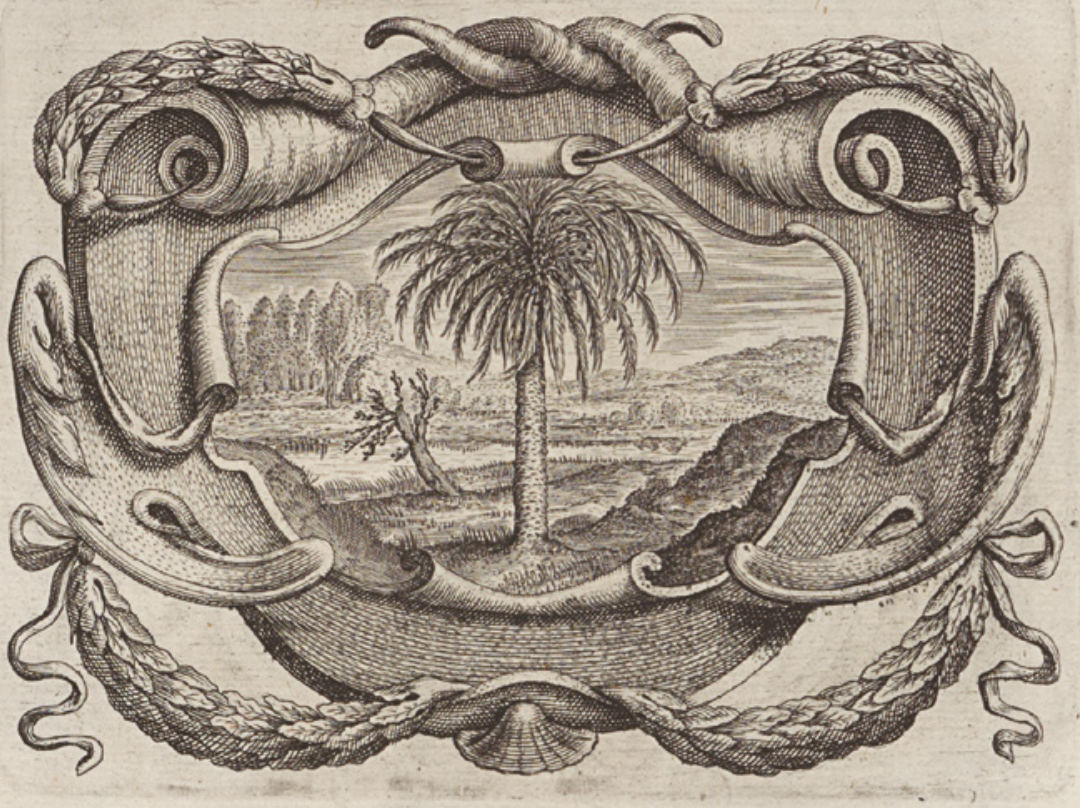

\section{In fenectâ vberi. Pfal.9I.}

FIGURE 2.25 Cornelis Galle and Philippe Fruytiers, Societas anno saeculari copiosos fructus promittit, in de Bolland and Henskens, eds., Imago primi saeculi Societatis Iesv, 5o, engraving (call no. vB 8.556 C). Brussels, Bibliothèque Royale de Belgique, Rare Books PHOTO: (C) BIBLIOTHÈQUE ROYALE DE BELGIQUE

209 Putnam, "Frontispiece and Opening Emblem of the Imago," 52, 54. Ps 91:15 in the Vulgate is numbered as Ps 92:14 in translation. Ps 92:14: "In old age they still produce fruit; / they are always green and full of sap." 
This, Loiola, is your tree that JESUS

planted and he himself again and again nurtured with his own hand. It has been the target of many winds, of many gales. Nevertheless from this it has absorbed its spirit, from this its own resource. It stands secure and now it embraces the whole world with its branches. And now it will be heavy with produce, as from long life. Its supply of fruit will grow as the centuries will grow, and each and every subsequent year will be more fecund.210

But to create a truly catholic Roman Catholic Church, Jesuits realized that conventional tools had to be revised, and for art, this meant revisiting what defined imagery, how it should be used, and when it could be trusted. Jesuit illustrated books were highly self-conscious constructions, whose authors carefully attended to the way visual evidence staked its claims, as in the prefaces and dedications of David's emblem books, which laid the groundwork for a "doctrina imaginis" that privileged images as instruments of spiritual reflection, instruction, and renewal. ${ }^{211}$ Picture-making as a means of holding the image of Christ to the soul was a popular conceit, as in the Imago emblem entitled Institutio iuuentutis (The education of youth), whose motto repeats in Greek and Latin: "Until CHRIST Takes Shape in You. Galatians 4[:19]" ("Achris ou morphôthê Christos en hymîn. / Donec formetur CHRISTUS in vobis. Gal. 4."), and whose poem depicts Jesuits as artists of the spirit: "Shape and carve, O thrice-blessed / sculptors of minds. [...] / You create not the shapes of mortals and / of goddesses, but your carvings are the Divine Christ" (fig. 2.26). ${ }^{212}$ In the picture, the statue of Christ extends his finger, like Michelangelo's $\left(1475^{-1564)}\right.$ God bestowing the spark of life to Adam on the Sistine Chapel ceiling, to infuse the sculptor with genius, but unusually, Christ indicates the battery-like globus cruciger in his right hand as its source. Dekoninck has maintained that by the time of the Imago, continuing efforts to evangelize the New World had encouraged the formation of new members of the Roman Catholic Church as products of Bildung in Christianity's own Pygmalion myth. ${ }^{213}$ Jesuits

\footnotetext{
210 O'Malley, Art, Controversy, and the Jesuits, 438-39.

211 De Boer, Enenkel, and Melion, Jesuit Image Theory; Dekoninck, Ad imaginem, 63-99; Melion, "Ut pictura lex," 149-86; Melion and Dekoninck, "Jesuit Illustrated Books," 527, 535.

212 Gal 4:19: "My little children, for whom I am again in the pain of / childbirth until Christ is formed in you." O'Malley, Art, Controversy, and the Jesuits, 566-67. I am indebted to Andrea Aldo Robiglio for so generously transliterating the Greek texts for this volume.

213 Ralph Dekoninck, "La passion des images: La traversée des images jésuites entre Ancien et Nouveau Mondes," De zeventiende eeuw 21, no. 1 (2005): 49-63, here 51-54; Zierholz, Räume der Reform, 23-64, esp. 61-63.
} 


\section{IMAGO PRIMI SACVLI SOC. IESV. Inftitutio iuuentutis.}

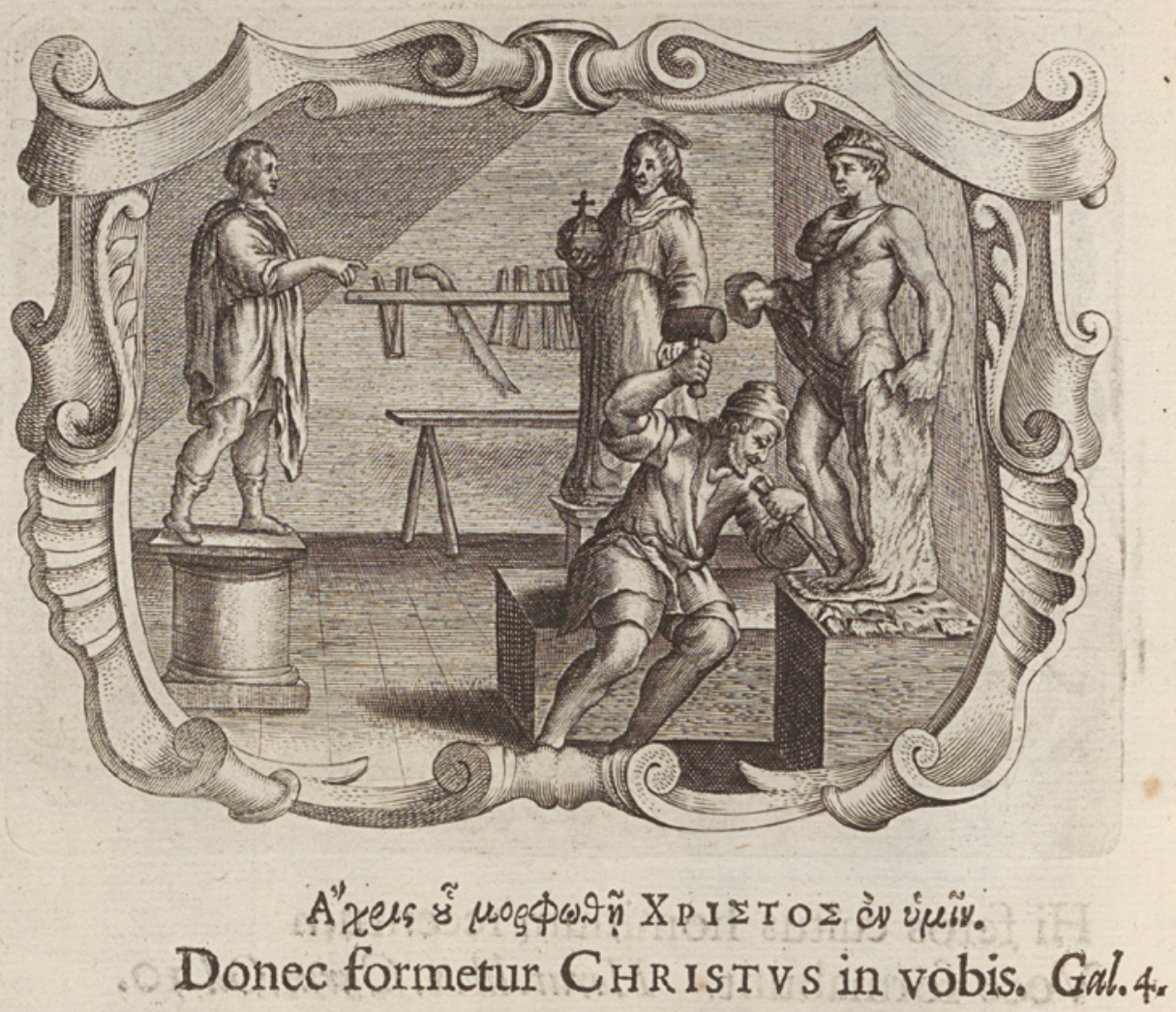

FIGURE 2.26 Cornelis Galle and Philippe Fruytiers, Institutio iuuentutis, in de Bolland and Henskens, eds., Imago primi saeculi Societatis Iesv, 468, engraving (call no. vB 8.556 C). Brussels, Bibliothèque Royale de Belgique, Rare Books PHOTO: (C) BIBLIOTHÈQUE ROYALE DE BELGIQUE

took the world and its original mechanisms of communication as a starting point for their ars symbolica (symbolic art), the verbo-visual compound of emblems thought to be the most faithful vestige of ancient Adamic language. They sought to inaugurate a novel lingua universalis (universal language) that could restore the harmony lost between God and world, wherein the Imago's emblems became "one body with the world, a pure reflection of the divine, 
before the Fall threw a veil of mystery over creation."214 Through the combination of world and spiritual fecundity, the authors of the Imago attempted to forge a common, healing visual language from a globally constructed notion of the fallen self in a riven society. ${ }^{215}$

As a result, the Imago primi saeculi Societatis Iesv was a more public-facing text than either the Spiritual Exercises or Nadal's Evangelicae historiae imagines; it sought to dispense an everyman's message in the emblem Societatis operarij (Laborers of the Society), which advises the adoption of an "all for all" "Omnibus omnia.") approach, a reference to 1 Corinthians 9:22: "I / have become all things to all people, that I might by all means / save some" (fig. 2.27). ${ }^{216}$ In what might be considered the final rebuttal to a single "Jesuit style," its poem explains that apparent dissimilarity need not detract from a consistent identity, as can be seen in the range of Jesuit art:

As in a mirror, appearances and movements gleam back and the smooth surface returns the details that confront it, in similar fashion resourceful love turns itself into all the shapes of humankind so that it becomes ALL THINGS TO ALL PEOPLE.

Melion and Dekoninck have interpreted this idea as, "whether a person was black or white, beautiful or ugly mattered not a wit, for Ignatius mirrored the body to capture the soul." ${ }^{217}$ The poem concludes: "That love might / render everyone similar to himself, he himself, we may / be sure, is time after time rendered unlike himself," in a fairly radical reimagining of the elastic potential of mimetic reproduction. Foundations for Jesuit art passed over appearances and were not concerned with skin-deep beauty or a specific style; ethical criteria trumped aesthetic traits in a spirituality that cherished the abundance and variety of the world and its peoples. ${ }^{218}$

Books like the Spiritual Exercises, Nadal's Evangelicae historiae imagines, and the Imago primi saeculi Societatis Iesv provided an imaginotheca, or portable library of ideas, for mixing and matching motifs, to endow pictorial communication with ever more rhetorical force and Ignatian techniques of

\footnotetext{
214 Dekoninck, "Jesuit Emblematics between Theory and Practice," [6-7].

215 Dekoninck, Ad imaginem, 35-48.

216 Dekoninck, "Jesuit Emblematics between Theory and Practice," [8]; O'Malley, Art, Controversy, and the Jesuits, 534-35; San Juan, Vertiginous Mirrors, 30-49.

217 Melion and Dekoninck, "Jesuit Illustrated Books," 536-37.

218 Dekoninck, "Jesuit Emblematics between Theory and Practice," [7].
} 


\section{IMAGO PRIMISECVLI SOC. IESV.}

\section{Societatis operarij.}

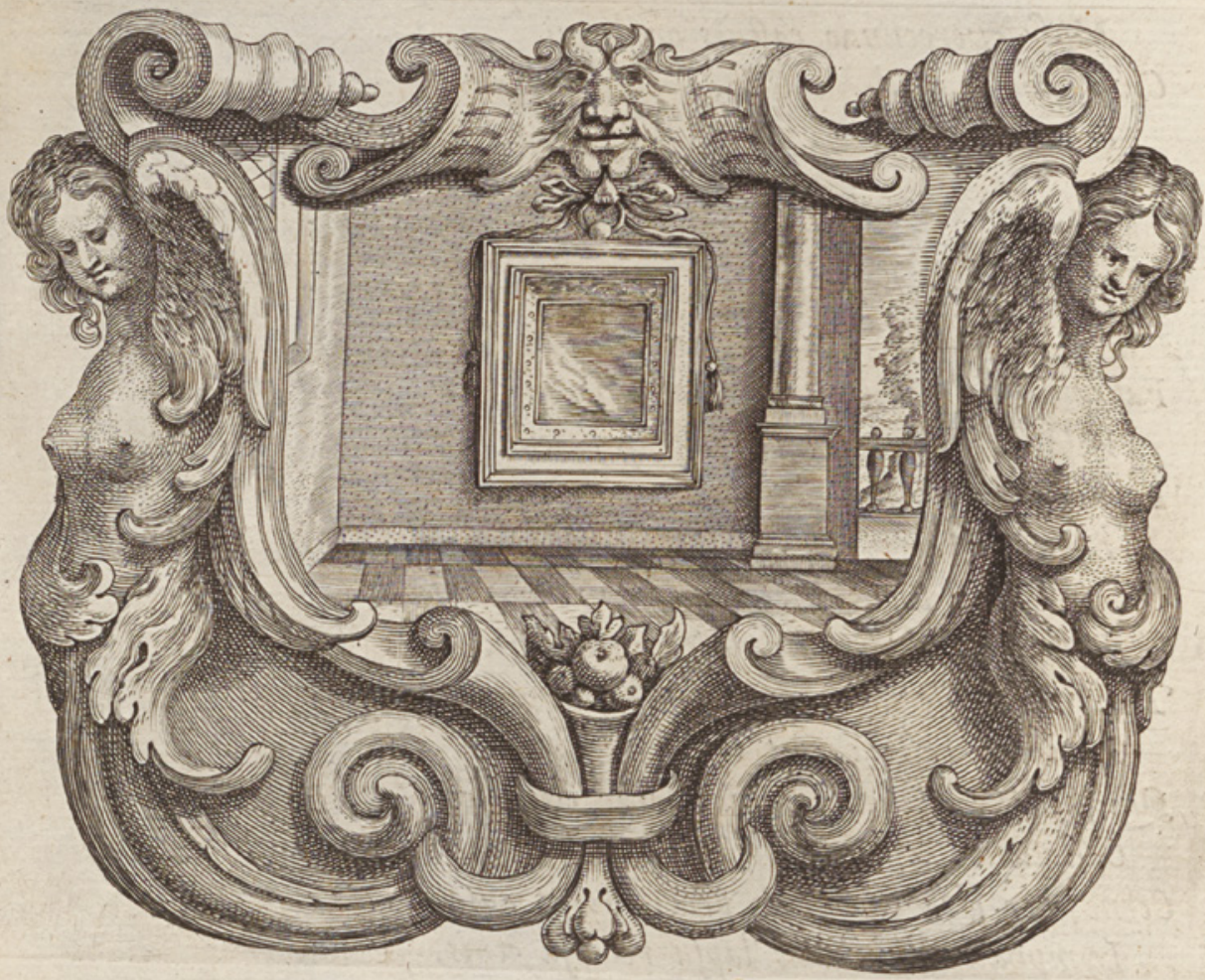

\section{Omnibus omnia.}

FIGURE 2.27 Cornelis Galle and Philippe Fruytiers, Societatis operarij, in de Bolland and Henskens, eds., Imago primi saeculi Societatis Iesv, 452, engraving (call no. vB 8.556 C). Brussels, Bibliothèque Royale de Belgique, Rare Books PHOTO: () BIBLIOTHÈQUE ROYALE DE BELGIQUE 
argumentation. ${ }^{219}$ Visual descendants from the Imago can also be located around the world and across media: first for emblem paintings, or affixiones, like those that would decorate the Jesuit Church of St. Charles Borromeo in Antwerp for the jubilee celebrations in 1640, and then more distantly with twenty emblems in the stained glass windows of the Church of St. Jodoc (or St. Josse) in Blatten, near Malters (canton of Lucerne, Switzerland, 1656-57), forty emblems in the polychrome reliefs of the Jesuit Church of San Salvador and Santo Domingo de Silos in Cordoba (Argentina, c.1671), and elements drawn from at least two emblems in an elaborate retable in the Iglesia San Ignacio in Bogotá (Colombia) by the sculptor Pedro Laboria (c.1700-70) in 1748.220 This trail of shared designs is telling not only for its concrete examples of how illustrated books shaped a pictorial habitus beyond simply other books, which has been widely recognized, but also for its testimony to how the concepts that would come to characterize Jesuit imagery were explored. The sources of an early modern "Jesuit style" culminated in a discourse of emblems epitomized by books like the Imago primi saeculi Societatis Iesv, one whose symbolic culture would leave its indelible trace on the Society's identity, for better or worse, and whose universal language would prefigure the formulation of iconology, as Dekoninck has contended, and I would argue further, the structure of the modern image..$^{221}$

219 Van Vaeck, Van Houdt, and Roggen, "Imago primi saeculi Societatis Iesu as Emblematic Self-presentation and Commitment," 196.

220 Sergio Barbieri, Empresas sacras jesuíticas: Córdoba, Argentina, Historia de la arquitectura de Córdoba 5 (Cordoba: Fundación Central, 2003), 89-102; Dieter Bitterli, "Emblemata. ch: An Inventory of Swiss Applied Emblems, ca. 160o-1780"; http://www.emblemata. ch/emblemata.ch/Home.html (accessed March 15, 2020); Dieter Bitterli, "Imago Sancto Judoci: An Unknown Cycle of Applied Emblems in Central Switzerland," in Visual Words and Verbal Pictures: Essays in Honour of Michael Bath, ed. Alison Saunders and Peter Davidson (Glasgow: Glasgow Emblem Studies, 2005), 13-36; Salviucci Insolera, L'imago primi saeculi (1640) e il significato dell'immagine allegoria nella Compagnia di Gesù, 59-107, 219-22; Rafael García Mahíques, "Fuentes para el programa emblemático en la Iglesia de la Compañía en Córdoba (Argentina): El Imago primi saeculi," in Lecturas de historia de arte: Vol. 4, ed. Instituto de Estudios Iconográficos (Vitoria-Gasteiz: Instituto de Estudios Iconográficos Ephialte, 1994), 394-403; Porteman, Emblematic Exhibitions (Affixiones) at the Brussels Jesuit College (1630-1685); Santiago Sebastian, El barroco iberoamericano: Mensaje iconográfico (Madrid: Encuentro, 1990), 341-42; Leonardo Ramírez Uribe, "El retablo del Rapto de la Iglesia de San Ignacio (Bogotà)," Apuntes 16 (1980): 43-48; Van Vaeck, Van Houdt, and Roggen, "Imago primi saeculi Societatis Iesu as Emblematic Self-presentation and Commitment," 175-94.

Dekoninck, "Jesuit Emblematics between Theory and Practice," [10]. 


\section{Part 3: Contributions}

\subsection{The Networked Image}

Today's researcher of Jesuit art is well placed to assume a Janus-like point of view, in honor of the ancient Roman god's ability to see both past and future, for he or she can as easily look to its sources as consider how it contributed to the longue durée of art history. The worldwide production of western art pioneered by the Jesuits resulted in a modern image defined by its networks, technological innovation, and subjective posture, all systems sympathetic to the transition-rich Ignatian "way of proceeding." The exemplary case of the networked image is the Salus Populi Romani Madonna, as it registered four frameworks, beginning with the global Jesuit network in which it was constructed. The Salus Populi Romani Madonna was the miraculous icon Blessed Inácio de Azevedo displayed in his portrait, one that has long enjoyed the continued devotion of the Society of Jesus, as seen in Pope Francis I's visit before his trip to Brazil in 2013 (figs. 1.6-1.7). The Salus Populi Romani Madonna, purported to have been painted by the Evangelist St. Luke, depicts Mary cradling the Christ Child as he holds a book in his left hand and raises his right hand in benediction (fig. 3.1). Its cabinet-sized dimensions belie its global significance, since the circulation of the Salus Populi Romani Madonna created a single continuum for artistic fabrication that could serve Europe and the Society's extra-continental missions. Copies of this specific Madonna can be found wherever Jesuits were active in the early modern world, from Rome to the farthest reaches in Japan and everywhere in between. For example, an oil-oncopper Salus Populi Romani Madonna in the Tokyo National Museum has been attributed to a western artist, due to stylistic and material analysis (fig. 3.2). ${ }^{222}$ Some European artists - Sigismondo Laire (1552-1639), Valeriano, and João de Mayorga (c.1533-70), for example-were known to specialize in reproductions of the Salus Populi Romani Madonna. Valeriano would garner an international reputation for his copies of the Madonna, judging by a letter from Alessandro Valignano (1539-16o6), Jesuit visitor to the Indies (South, Southeast, and

222 Illustrated Catalogue of Tokyo National Museum: Kirishitan Objects; Christian Relics in Japan 16-19th Century, rev. ed. (Tokyo: Tokyo National Museum, 2001), 34, 162, 235, fig. 38, inv. no. C695; Nobuyuki Kamba, "Kirishitan kaiga no seisaku gijutsu to zairyō (1), Ōsaka-fu Ibaraki-shi ni oite hakken sareta sakuhin," Tōkyō Kokuritsu Hakubutsukan kiyō 42 (2006): 5-122; Kojima, "Reproduction of the Image of Madonna Salus Populi Romani in Japan," 374-78; Tei Nishimura, Nihon shoki yōga no kenkyū (Osaka: Zenkoku Shobō, 1945), 19-21; Midori Wakakuwa, Seibozō no tōrai (Tokyo: Seidosha, 20o8), 133-34. 


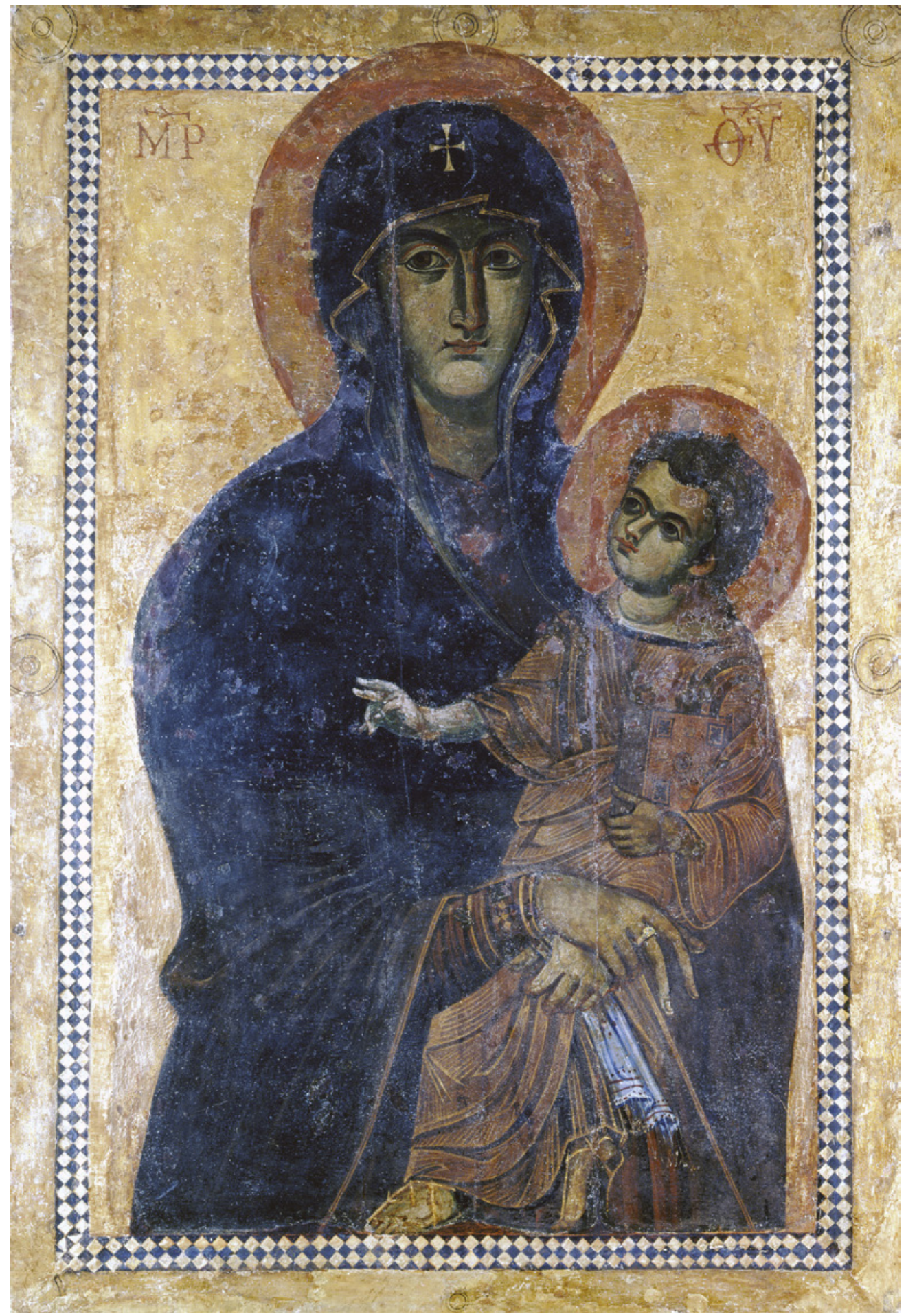

FIGURE 3.1 Anonymous, Salus Populi Romani Madonna, sixth-tenth century, tempera on panel. Rome, Basilica of Santa Maria Maggiore, Borghese Chapel PHOTO: (C) FOTO VASARI ROMA/ALESSANDRO VASARI (INV. NO. 04/06/EK) 


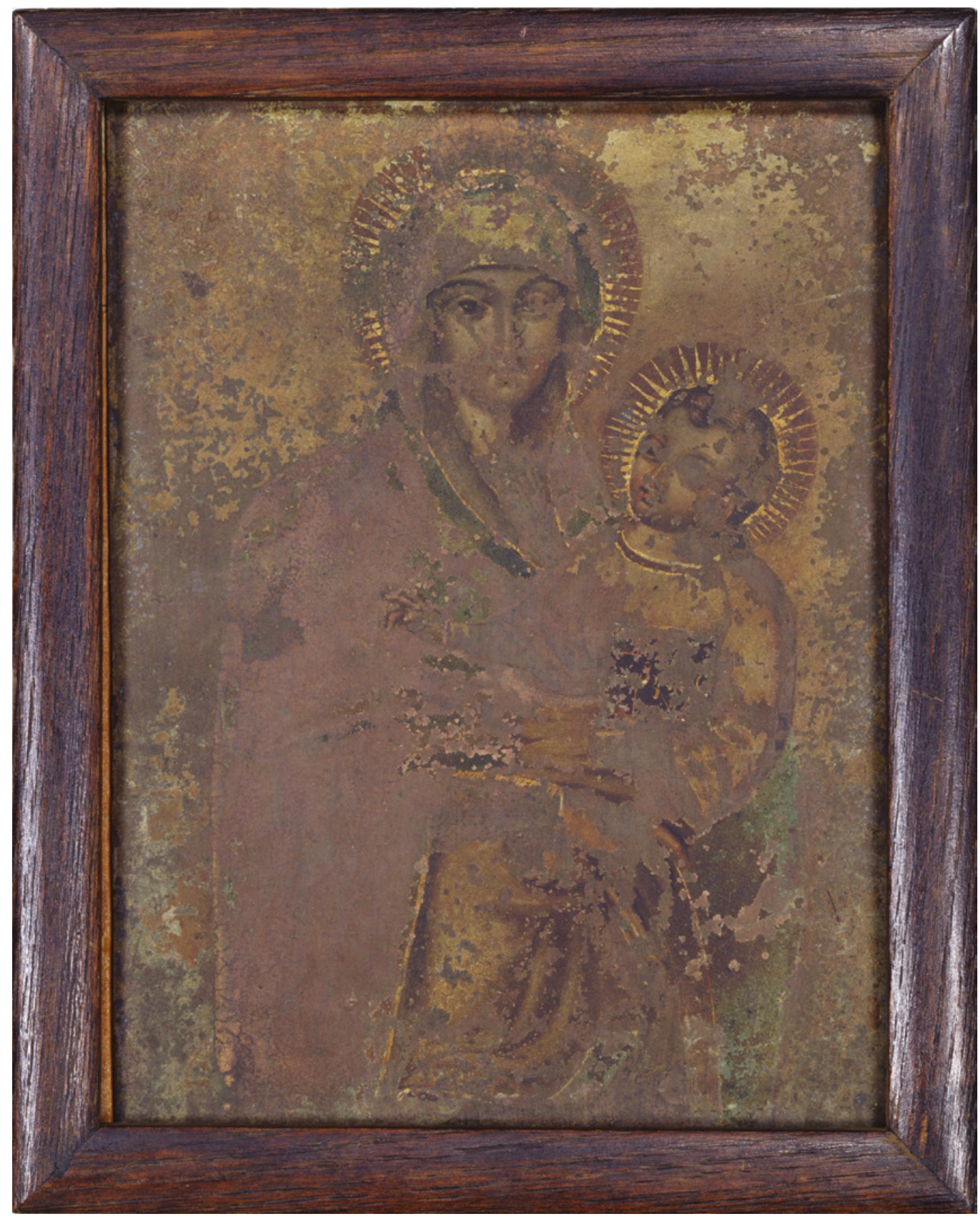

FIgURE 3.2 Anonymous, Salus Populi Romani Madonna, late sixteenth century-early seventeenth century, oil on copper (inv. no. C695). Tokyo, Tokyo National Museum

PHOTO: () TNM IMAGE ARCHIVES 
East Asia), imploring Superior General Mercurian to send Valeriano to Japan in $1575 .{ }^{223}$

Other copies of the Salus Populi Romani Madonna were made on site, and their iconographic details reveal not only before and after versions of the icon, but also preferences derived from multiple stops along various itineraries. ${ }^{224}$ So, subsequent to a stop-over in Agra or Goa, Ethiopian versions of the Salus Populi Romani Madonna could appear with immaculate conception scenes, in which Mary's hair was bound in a topknot, or depictions of the Raising of Adam and Eve, complete with Indian fabrics and poses. ${ }^{225}$ Copies of secondand third-generation replicas of the Salus Populi Romani Madonna enabled the image to reach ever-widening audiences. After Bishop Pedro Martins's (or Martínez, 1542-98) visit to the Niccolò workshop at the Arie Seminary in Japan in 1596, Frois would observe:

Finally, the thing which astonished them the most was to enter a long building overflowing with boys and young men who were painters, every one of them with his picture in his hand, painting various images in oil, which, when they were finished, the Father Vice-Provincial went to hand out to the Christian gentlemen and those in the Society. At the front of this building was placed an image of Our Lady after St. Luke painted by one of these students who was nineteen years old [i.e., Luís Shizuoka]. They were at great pains to believe that such a perfect and accomplished work had been produced by a mere boy. ${ }^{226}$

At its most basic level, the Salus Populi Romani Madonna copies were the natural accretion of the extensive global Jesuit network represented in Athanasius Kircher's (1602-80) Horoscopium catholicum Societatis Iesv as a tree rising from

223 Gauvin Alexander Bailey, "Creating a Global Artistic Language in Late Renaissance Rome: Artists in the Service of the Overseas Missions, 1542-1621," in From Rome to Eternity: Catholicism and the Arts in Italy, ca. 1550-1650, ed. Pamela M. Jones and Thomas Worcester, S.J. (Leiden: Brill, 2002), 225-51, here 231; Thomas M. McCoog, S.J., ed., With Eyes and Ears Open: The Role of Visitors in the Society of Jesus, Jesuit Studies 21 (Leiden: Brill, 2019).

224 Mochizuki, "Fukusei gijutsu jidai ni okeru shūkyōga," 273-97; Mochizuki, "Sacred Art in an Age of Mechanical Reproduction," 129-44.

225 Marilyn Heldman, Stuart C. Munro-Hay, and Roderick Grierson, eds., African Zion: The Sacred Art of Ethiopia, exh. cat. (Baltimore: Walters Art Gallery, 1993), 194.

226 Luís Shizuoka entered the seminary in 1587 and was dismissed from the Society in 1615 . ARSI, Jap. Sin. 46, fol. 283"; Bailey, Art on the Jesuit Missions in Asia and Latin America, 69-70; Schütte, "Christliche Japanische Literatur," 264. 
St. Ignatius, with each branch, a Jesuit province; each leaf, a Jesuit school, novitiate, or college, to show how the data needed to make a "universal clock" was compiled (fig. 3.3). ${ }^{227}$ Jesuit visual networks, fueled by an Ignatian reverence for the world and the vita activa advocated by Nadal, functioned like Bruno Latour's notion of awe-inspiring "retia mirabilia," or performative "seen networks," where the constantly shifting array of contacts and conduits mattered more than any single artistic center, in accordance with a "routes, not roots" approach. ${ }^{228}$

The second network the Salus Populi Romani Madonna relied upon was the Portuguese trade routes. One of the first copies of the Salus Populi Romani Madonna was delivered to Dona Catarina of Austria (1507-78), wife of King João III of Portugal (1502-57, r.1521-57), by Azevedo on his fatal trip to Brazil (fig. 3.4). In a letter dated July 2, 1569, Borja explained:

I am sending Your Excellency a gift that I hope will be to your royal taste, while to me it offers much consolation. I believe, in fact, that the painting that he [i.e., Azevedo] will bring to Your Excellency is certainly one of the most remarkable gifts that a queen, devoted to the Mother of God, could possess. It is a copy of the painting done by Saint Luke, preserved in the

227 The goal of the Horoscopium catholicum Societatis Iesv, dedicated to Superior General Vincenzo Carafa (1585-1649, in office 1644-49) on January 7, 1646, was "to construct the timepiece for the whole Jesuit Order" and "tell time everywhere, but especially in the colleges of the Society of Jesus, scattered throughout the world": "Knowing the differences between the times when an eclipse was observed, for example, in Nanking [or Nanjing] in China, from that of the same eclipse observed in Goa in India, Mozambique in Africa, Pernambuco in Brazil, and in several other stations, it was possible, though not without difficulty, to calculate the longitudes of each of these places, as well as of other places lying between them." Joscelyn Godwin, Athanasius Kircher's Theatre of the World: His Life, Work, and the Search for Knowledge (Rochester, NY: Inner Traditions, 2009), 202; Steven J. Harris, "Mapping Jesuit Science: The Role of Travel in the Geography of Knowledge," in O'Malley et al., Jesuits, 212-40, here 219-22; Lucas, Saint, Site, and Sacred Strategy, 142.

228 Finbarr B. Flood, Objects of Translation: Material Culture and Medieval "Hindu-Muslim" Encounter (Princeton: Princeton University Press, 2009), 1-5; Bruno Latour, Reassembling the Social: An Introduction to Actor-Network-Theory (Oxford: Oxford University Press, 2005), 128-33, 220.

FIGURE 3.3 Pierre Miotte, Horoscopium catholicum Societatis Iesv, in Athanasius Kircher, Ars magna lucis et umbrae (Rome: Hermann Scheus and Ludovico Grignani, 1646), 553, engraving (call no. vB 5.009 1 C). Brussels, Bibliothèque Royale de Belgique, Rare Books PHOTO: () BIBLIOTHÈQUE ROYALE DE BELGIQUE 


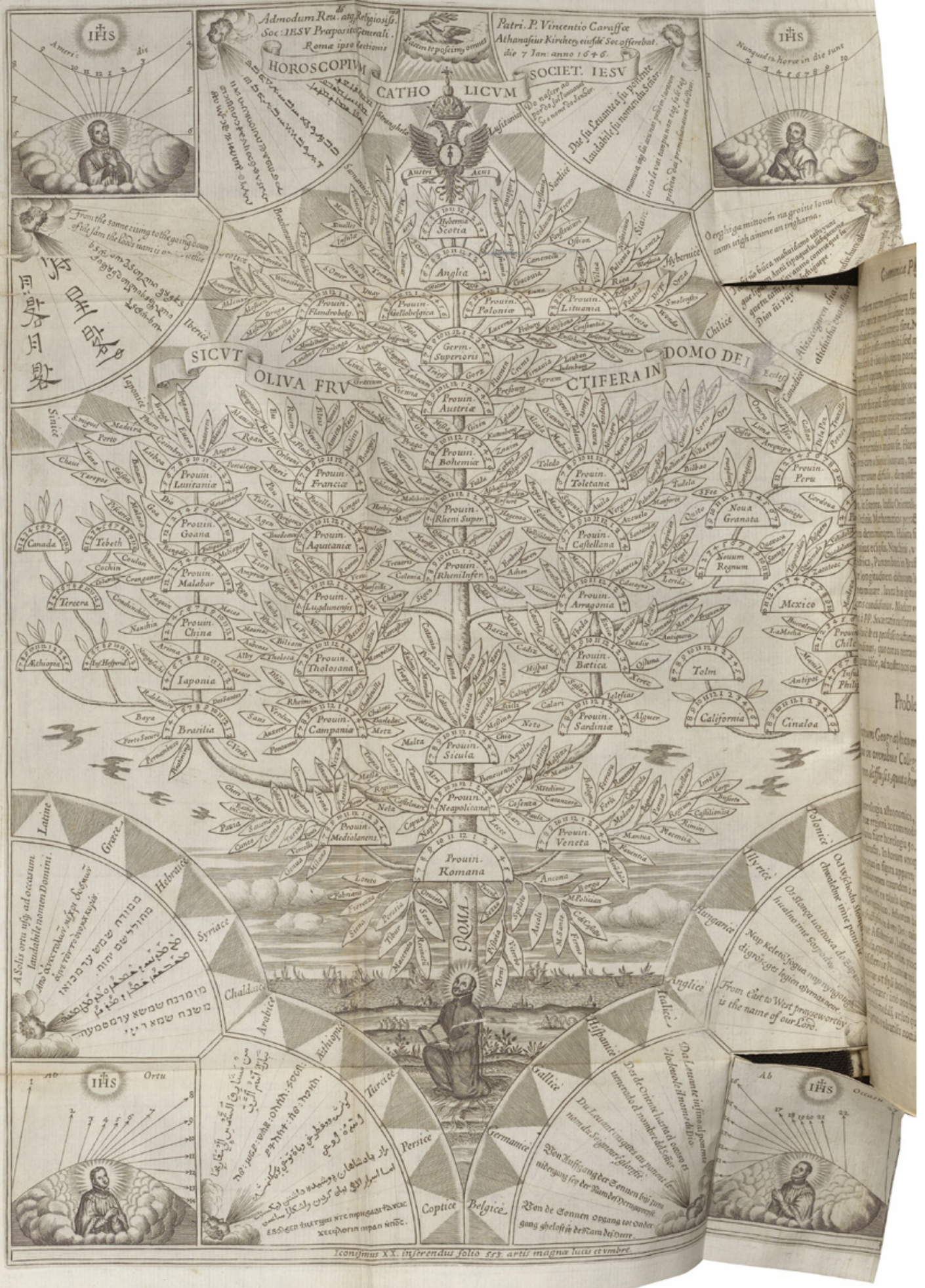


Church of Santa Maria Maggiore, where it is worshipped with all possible devotion. In exchange for this gift, I beg Your Excellency to put it in your chapel above the altar of your oratory, and to have for it the same devotion that the pope does in his own church. ${ }^{229}$

Before Borja sent copies of the Salus Populi RomaniMadonna as diplomatic gifts to other European monarchs, such as Philip II of Spain, Elisabeth of Austria (1554-92, r.1570-74), and several German prince electors; before he directed likenesses to the devout daughters of the Holy Roman emperor Charles v, Maria of Austria (1528-1603, r.1564-76) and Joanna of Austria (1535-73, r.155254), who was a reputed member of the Society of Jesus under the pseudonym "Mateo Sánchez"; before he selected versions for his own first-born son Don Carlos de Borja y de Castro (1530-92) and his sisters, the honor of receiving the first reproduction of the copy of this sacred icon, like the dedication of a book, was presented to a ruler of the Portuguese realm. ${ }^{230}$ Copies of the Salus Populi

229 Borja y Enríquez, Sanctus Franciscus Borgia, 5:112-13; Maria de Lurdes Craveiro, "João de Mayorga, um pintor aragonês em Portugal no século XVI," in Relaciones artísticas entre Portugal y España, ed. Jesús M. Caamaño (Valladolid: Junta de Castilla y León, Consejería de Educación y Cultura, 1986), 91-109, here 101; d'Elia, "Prima diffusione nel mondo dell'immagine di Maria 'Salus Populi Romani," 302-3; Kirstin Noreen, "The Icon of Santa Maria Maggiore, Rome: An Image and Its Afterlife," Renaissance Studies 19 (November 2005): 660-72, here 664; Suau, Histoire de Saint François de Borgia, 414, n. 1.

230 Elisabeth of Austria became queen of France as the wife of King Charles Ix (1550-74, r.156o-74); Maria of Austria became Holy Roman empress as the wife of Maximilian II (1527-76, r.1564-76); and Joanna of Austria became princess of Portugal through marriage to Prince João Manuel (1537-54) and regent of Spain for her brother Philip II when he was abroad. Arquivo Histórico Santa Casa Misericórdia Lisboa (AHSCML), "Rol dos Moves da Botica e Capela dos Enfermos e Enfermarias, 1673," in Inventário de 16oo, Cartapacio, DR 255, fol. 127 ${ }^{\text {r }}$ Bailey, Art on the Jesuit Missions in Asia and Latin America, 70; Gauvin Alexander Bailey, "Italian Renaissance and Baroque Painting under the Jesuits and Its Legacy Throughout Catholic Europe, 1565-1773," in O'Malley and Bailey, Jesuits and the Arts, 124-98, here 126; Lisa Fullam, "Juana, S.J.: The Past (and Future?) Status of Women in the Society of Jesus," Studies in the Spirituality of Jesuits 31, no. 5 (November 1999): 1-39; António Meira Marques Henriques, "A devoção jesuíta a Nossa Senhora de S. Lucas: Estudo de dois quadros do Museu de São Roque," Brotéria 176 (February 2013):152-6o, here 156-59; Fausto Sanches Martins, "Culto e devoção das igrejas dos jesuítas em Portugal," in A Companhia de Jesus na Península Ibérica nos sécs. XVI e XVII: Espiritualidade e cultura; Actas do colóquio internacional, maio 2004, ed. Centro Interuniversitário de História da Espiritualidade and Instituto de Cultura Portuguesa, Universidade de Porto (Porto:

FIGURE 3.4 Italian Artist, Salus Populi Romani Madonna, c.1569, oil on canvas (inv. no. 127). Lisbon, Museu de São Roque 


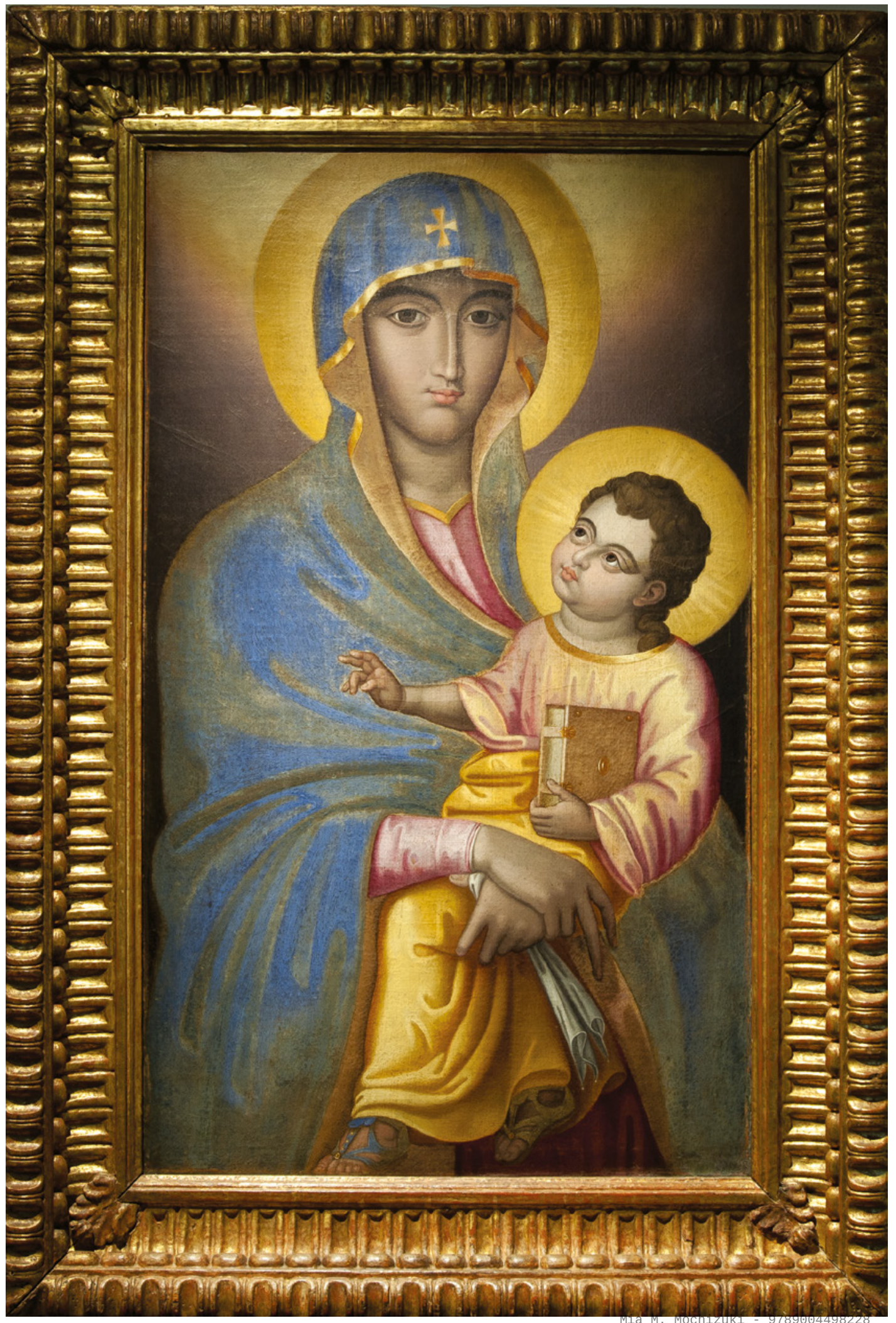


Romani Madonna proliferated throughout the kingdom of Portugal, only second to those in Italy, particularly by artists such as Mayorga, who accompanied Azevedo to Brazil..231 By António Meira Marques Henriques's accounting, at least five versions of the Salus Populi Romani Madonna should be attributed to Mayorga, all approximately the same size: the painting destined for Brazil, but also copies for the Jesuit College of Jesus in Coimbra, the College of St. Anthony in Lisbon, the College of the Holy Spirit in Évora, and the Church of St. John the Evangelist of the Jesuit College in Funchal, the capital of the island of Madeira then operating semi-autonomously, where Azevedo's ships stopped before crossing the Atlantic Ocean. ${ }^{232}$ The replicas of the Salus Populi Romani Madonna were the material result of the allegiances that cemented global passage.

Images like the Portuguese Nation in Heinrich Scherer's (1628-1704) Atlas novus (New atlas [Dillingen an der Donau: Johann Caspar Bencard, 1703-10]) show how the Salus Populi Romani Madonna spread abroad: the Portuguese kingdom was defined by its engagement with the peoples of India, Ethiopia, Brazil, Japan, the Hesperides Islands, and the Azores (fig. 3.5). ${ }^{233}$ These valuable outposts on the Portuguese eastern trading circuit were the very same locations where the Salus Populi Romani Madonna would appear in the world; the Jesuit network may have provided the administrative support, but without the trans-continental logistics sustained by the Portuguese monarchy, the Salus Populi Romani Madonna would never have left the shores of Belém. For western workshops located overseas, the circumvolution of imagery was simply an extension of intra-European Portuguese channels that would become what might be called a greater "Luso-exchange"

Universidade de Porto, 2004), 89-117, here 106-7; John E. McCall, "Early Jesuit Art in the Far East," Artibus Asiae 10 (1947): 121-37, 216-33, 283-301, here 135, 11 (1948): 45-69, 17 (1954): 39-54; Noreen, “Icon of Santa Maria Maggiore, Rome," 662-64; Wakakuwa, Seibozō no tōrai, 99 .

231 Craveiro, "João de Mayorga," 94, 100.

232 Henriques, "Devoção jesuíta a Nossa Senhora de S. Lucas," 152-6o.

233 The "Hesperides Islands," also called the "Fortunate Isles" or "Isles of the Blessed," can refer to the present-day Canary Islands, Madeira, Cape Verde, Bermuda, and the Lesser Antilles. Pope Alexander VI (1431-1503, r.1492-1503) brokered the Treaty of Tordesillas between João II (1455-95, r.1481-95) of Portugal (September 5, 1494), and on the Spanish side (July 2, 1494), Ferdinand II of Aragon (1452-1516, r.1479-1516) and Isabella I of Castile (1451-1504, r.1474-1504), that would divide the rest of the world between their kingdoms along a meridian 370 leagues west of the Cape Verde islands off the western coast of Africa, although the demarcation line for the other side of the world would only be specified several decades later in the Treaty of Zaragoza (April 22, 1529). 


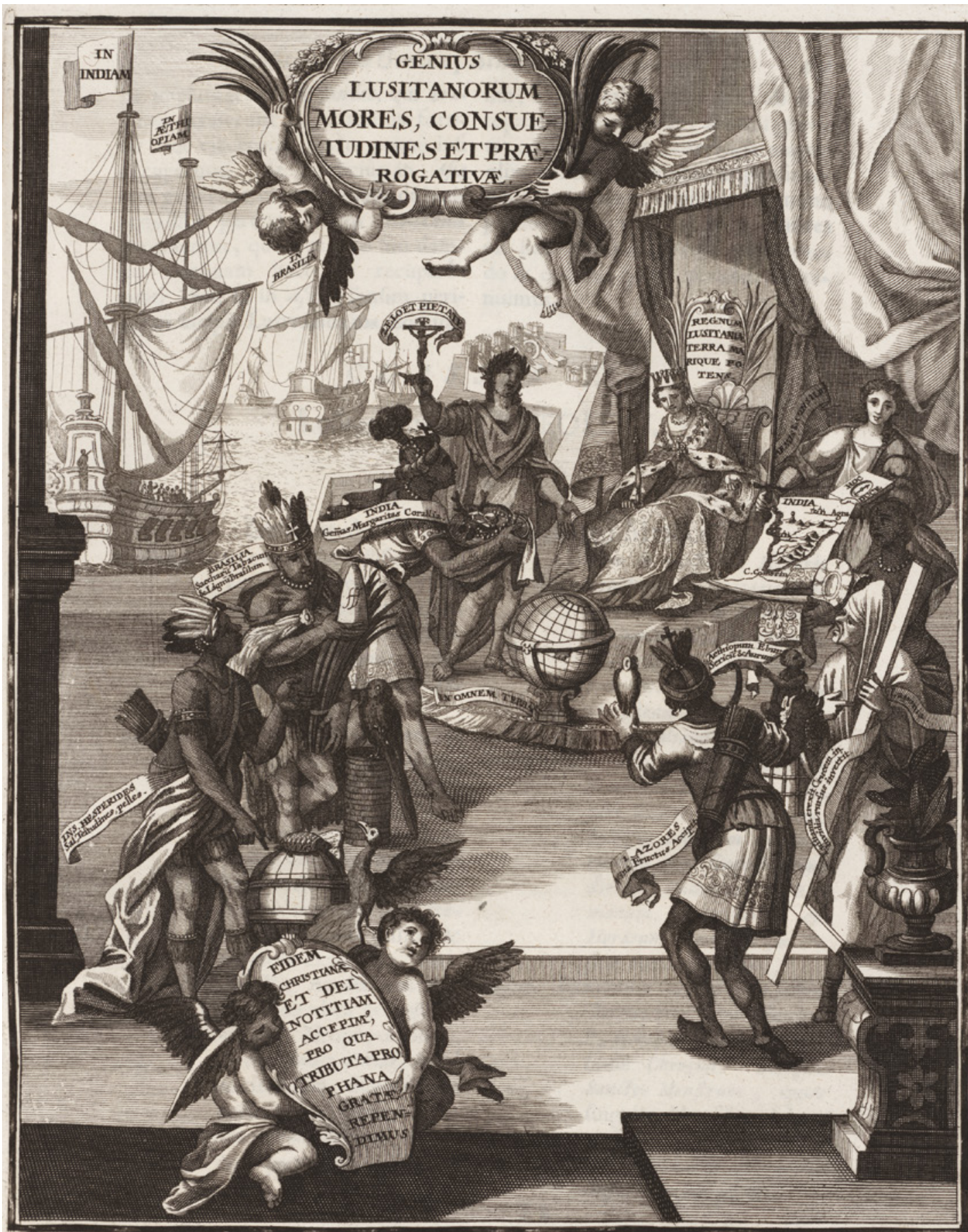

Ithisegler del:

Tar: i Montalegre foul pvit Norimbergue.

FIG URE 3.5 Joseph à Montalegre after Johannes Degler, The Portuguese Nation, in Heinrich Scherer, Atlas novus exhibens orbem terraqueum per naturae opera, historiae novae ac veterus monumenta, artisque geographicae leges et praecepts (Dillingen an der Donau: August Vindel, 1702-10), vol. 4, after 38, engraving (call no. G11. S4 v. 4). Berkeley, University of California, Bancroft Library (C) PUBLIC DOMAIN. PHOTO: UNIVERSITY OF CALIFORNIA, BERKELEY, BANCROFT LIBRARY 
network. ${ }^{234}$ A Luso-exchange provides a historically accurate model to supplement the hybridity studies popularly applied to global art that risk rehearsing the alignment of racial and ethnic heritage with regional fabrication and reenacting the "boundary fetishism" of cultural classification exposed by contact objects in national histories. ${ }^{235}$ When an expansion into a global production environment amplified the aporetic status of post-Tridentine objects, the links of the Luso-exchange effectively enhanced the authority of the devotional image.

The Society of Jesus turned to a third network, sacred art, for the chains of pictorial evidence that would guarantee the authenticity of the Salus Populi Romani Madonna's replicas. The first copy of the Salus Populi Romani Madonna, the ground zero of reproduction, was sent to the Jesuit novitiate in Rome, whose physical fabric was later subsumed into Sant'Andrea al Quirinale, where it is currently housed in a second-floor chapel dedicated to St. Stanisław Kostka (1550-68) (fig. 3.6). ${ }^{236}$ Before the copy of the Salus Populi Romani Madonna arrived in Azevedo's hands, before a version reached Queen Catarina, the initial likeness of the Salus Populi Romani Madonna was sent to the Society of Jesus. An inscription painted on its elaborate frame testifies to its status as the first copy ("Hanc imaginem / S. Franciscus Borgia / ab Exquilino exemplari / primam omnium esprimendam / curavit."), and rather extraordinarily, commemorates Borja's commissioning of the copy, instead of celebrating its artist or patron. ${ }^{237}$ Among all the achievements of the Society under Borja's leadership, this deed would be singled out in his official biography by Pedro de Ribadeneyra (1527-1611), Vida del padre Francisco de Borja (Life of Father Francisco de Borja [Madrid: Pedro Madrigal, 1592]), and a Portrait of St. Francisco de Borja with the Salus Populi Romani Madonna by Melchior Küsell (1626-c.1683) features Borja holding a copy of the Salus Populi Romani

234 Mia M. Mochizuki, "The Luso-Baroque Republic of Things and the Contingency of Contact," in "The Lusophone Baroque," Ellipsis:Journal of the American Portuguese Studies Association, Special Issue, 12, ed. Vincent Barletta (2014): 143-71.

235 George Kubler, "Indianism, Mestizaje, and Indigenismo as Classical, Medieval, and Modern Traditions in Latin America," in Studies in Ancient American and European Art, ed. Thomas Reese (New Haven: Yale University Press, 1986), 75-80; Jan Nederveen Pieterse, "5. Hybridity, So What? The Anti-hybridity Backlash and the Riddles of Recognition," Globalization and Culture: Global Mélange (New York: Rowman and Littlefield, 2003), $85^{-111 .}$

236 Reinhold Baumstark, ed., Rom in Bayern: Kunst und Spiritualität der ersten Jesuiten, exh. cat. (Munich: Bayerisches Nationalmuseum, 1997), 492-93.

237 "St. Francisco Borja arranged for this image, first among all others, to be modeled after the Esquiline [Hill] exemplar [i.e., the version in the Basilica of Santa Maria Maggiore]." 


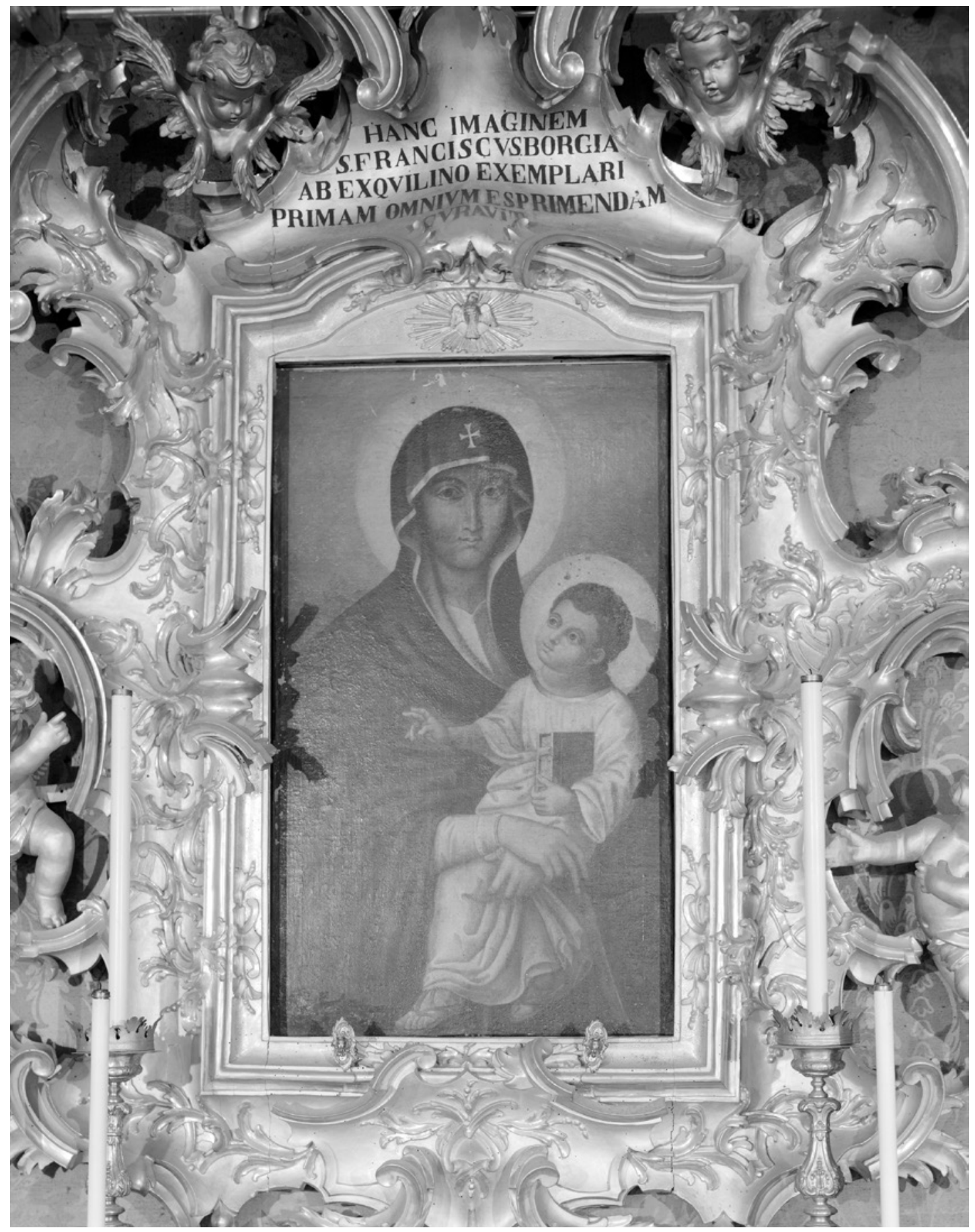

FIGURE 3.6 Anonymous Roman Artist, Salus Populi Romani, 1569, oil on panel. Rome, Sant'Andrea al Quirinale, Chapel of St. Stanislas Kostka (C) BIBLIOTHECA HERTZIANA, MAX-PLANCK-INSTITUT FÜR KUNSTGESCHICHTE, ROME (NEGATIVE NO. U.PL. D44424). PHOTO: OSCAR SAVIO 
Madonna in his left hand (fig. 3.7). ${ }^{238}$ According to the version of the story recounted by Daniello Bartoli (1608-85), during Azevedo's farewell audience with Pope Pius V (1504-72, r.1566-72), Borja requested that the Society be permitted to copy the Salus Populi Romani Madonna icon, since their missionary work was enacted under the "Queen of Angels."239 Although there was no precedent for it, Pope Pius permitted Borja to make the earliest official copies of the Salus Populi Romani Madonna, and in June 1569, the first copy of the Salus Populi Romani was painted by an unnamed Roman artist under the supervision of Cardinal St. Carlo Borromeo (1538-84, in office 156o-84), then archpriest of the Basilica of Santa Maria Maggiore. ${ }^{240}$ With this act, Pope Pius sealed the icon's status as the face of universal post-Tridentine Catholicism in Rome and Munich, Lisbon and Isfahan, Bahia and Beijing, Goa and Gorgora, by providing an irrefutable temporal backing for the "authentic copies" of the Salus Populi Romani Madonna. The Society of Jesus ushered in age of replication, where copies would no longer be spurned as derivative and power dynamics shifted from the maker in favor of the mediator.

The print medium could best achieve Borja's desire that sacred pictures be reproduced on silk, paper, and metal in "the greatest quantity to

238 Borja's right hand points to the crowned skull of Empress Isabella of Portugal (1503-39, r.1519-56), wife of the Holy Roman emperor Charles v, a reference to receiving his vocation during her funeral rites, another example of how closely Jesuit and Luso-exchange networks were interwoven. D'Elia, "Prima diffusione nel mondo dell'immagine di Maria 'Salus Populi Romani," 307, 311, n. 63; Noreen, “Icon of Santa Maria Maggiore, Rome," 662; Pedro de Ribadeneyra, Vita Francisci Borgiae (Antwerp: Joachim Trogney, 1598), 238-39; Ribadeneyra, Vida del padre Ignacio de Loyola, fundador de la religión de la Compañía de Iesus y de los padres maestro Diego Laynez y Francisco de Borja (Madrid: Pedro Madrigal, 1594), 826-27.

239 Daniello Bartoli cites public opinion in Rome in 1569 as his source. Daniello Bartoli, Degli uomini e de' fatti della Compagnia di Gesù: Memorie istoriche del p. Daniello Bartoli della medesima Compagnia; Opera postuma (Turin: Giacinto Marietti, 1847-56), 4, sec. 6:82; d'Elia, "Prima diffusione nel mondo dell'immagine di Maria 'Salus Populi Romani," 302, 310, nn. 13-14.

240 The artist is described as "a grand Roman painter" ("Un gran pintor de Roma"), "an excellent Roman artist" ("un excelente artifice Romano"), and "a famous brush, the pride of Italy and the soul of painting" ("Un famoso pincel, valentia de la Italia y alma de la pintura"). Álvaro Cienfuegos, La heroyca vida, virtudes y milagros del grande S. Francisco de Borja (Madrid: La Viuda de Juan García Infanzón, 1717), sec. 2:379-8o, book 5, chapter 9; d’Elia, "Prima diffusione nel mondo dell'immagine di Maria 'Salus Populi Romani," 306-7, 311, nn. 52-54, 61, 68; Dionisio Vázquez, S.J., "Historia de la vida del padre Francisco de Borja, 1586," unpublished Ms, Institutum Historicum Societatis Iesu, Rome, fols. $28 \mathrm{o}^{\mathrm{r}}-281^{\mathrm{r}}$. By the time of the Council of Trent, the title of archpriest was largely replaced by that of vicar forane, with exceptions for the rectors of some major basilicas, as in Rome and Malta; the dean of the Basilica of Santa Maria Maggiore is still referred to as archpriest. 


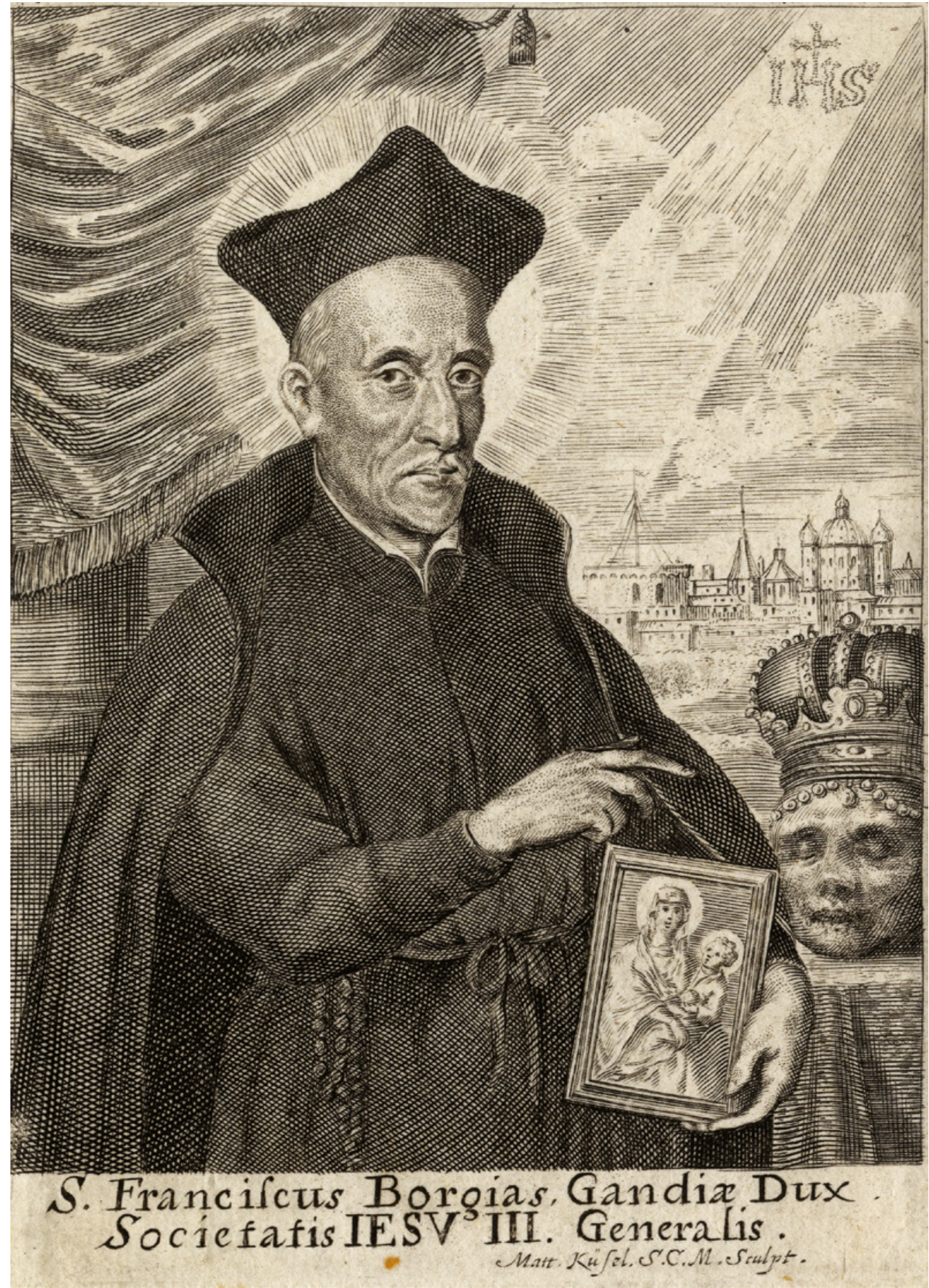

FI U RE 3.7 Melchior Küsell, Portrait of St. Francisco de Borja with the Salus Populi Romani Madonna, seventeenth century, engraving. Rome, Archivum Romanum Societatis Iesu, Fondo iconografico Lamalle, S. Francisco Borgia, sub nomine PHOTO: (c) ARCHIVUM ROMANUM SOCIETATIS IESU 
circulate images throughout the whole world," as he exhorted the novitiate of Sant'Andrea a Monte Cavallo. ${ }^{241}$ This was the function of the engraved version of the Salus Populi Romani Madonna in ink on paper, best known from the design of Hieronymus Wierix, who also worked on the Evangelicae historiae imagines (fig. 3.8). ${ }^{242}$ The unedited manuscript of Borja's biography, written by his twice-daily confessor Dionisio Vázquez (1528-89) in 1586, noted that copies of the first painted replica of the Salus Populi Romani Madonna were made on cloth, likely canvas and silk, as well as on metal sheets for printing. ${ }^{243}$ In the published biography of 1592, Ribadeneyra elaborated that Borja "sent various printed images on different types of materials; he even sent the kinds of printing tools and instruments needed to print other images, so that everywhere there was an abundance of such a rich treasure." ${ }^{244}$ Contemporary chroniclers claimed that Azevedo died clutching an engraved copy or plate of the icon. ${ }^{245}$ If the Jesuit global network and a Luso-exchange provided the logistical pipelines for the creation of copies of the Salus Populi Romani Madonna, it was the early modern endorsement by "image-chain," authenticity through pictorial descent, that paradoxically positioned the copy as the new indemnifier of legitimacy, like a visual nihil obstat. Jesuits like Canisius justified this method of endorsing sacred art in his De Maria Virgine incomparabili et Dei genitrice sacrosancta libri quinque (Five books on Mary, Incomparable Virgin and Most Holy Mother of God [Ingolstadt: David Schneider, 1577]) thusly: despite different styles and modified iconographies, representations of the Virgin could qualify as "Lukan images," whether St. Luke painted multiple paintings himself or he executed a single archetype from which an unbroken meta-lineage of pictorial authority flowed, so long as they were made directly after one of the representations attributed to him. ${ }^{246}$ Image-chains meant that meaning

241 D'Elia, "Prima diffusione nel mondo dell'immagine di Maria 'Salus Populi Romani," 306; Vázquez, "Historia de la vida del padre Francisco de Borja, 1586," fols. $28 \mathrm{o}^{\mathrm{r}}-281^{\mathrm{r}}$.

242 Mauquoy-Hendrickx, Estampes des Wierix, 1:141-42, pl. 113, fig. 797.

243 D'Elia, "Prima diffusione nel mondo dell'immagine di Maria 'Salus Populi Romani,"” 303, 306, 311, n. 61; Vázquez, "Historia de la vida del padre Francisco de Borja, 1586," fols. $28 \mathrm{o}^{\mathrm{r}}-281^{\mathrm{r}}$.

244 D'Elia, "Prima diffusione nel mondo dell'immagine di Maria 'Salus Populi Romani," 307, 311, n. 63; Ribadeneyra, Vida del padre Ignacio de Loyola, 826-27.

245 D'Elia, "Prima diffusione nel mondo dell'immagine di Maria 'Salus Populi Romani," 302-3; Noreen, "Icon of Santa Maria Maggiore, Rome," 664; Mario Scaduto, S.J., L'opera di Francesco Borgia 1565-1572 (Rome: La Civiltà Cattolica, 1992), 94-95; Wolf, Salus Populi Romani, 248, fig. 126.

246 Peter Canisius, Commentarium de Verbi Dei corruptelis [Commentary on the corrupters of the divine word] (Ingolstadt: David Schneider, 1573), 761, book 5, chapter 12; 


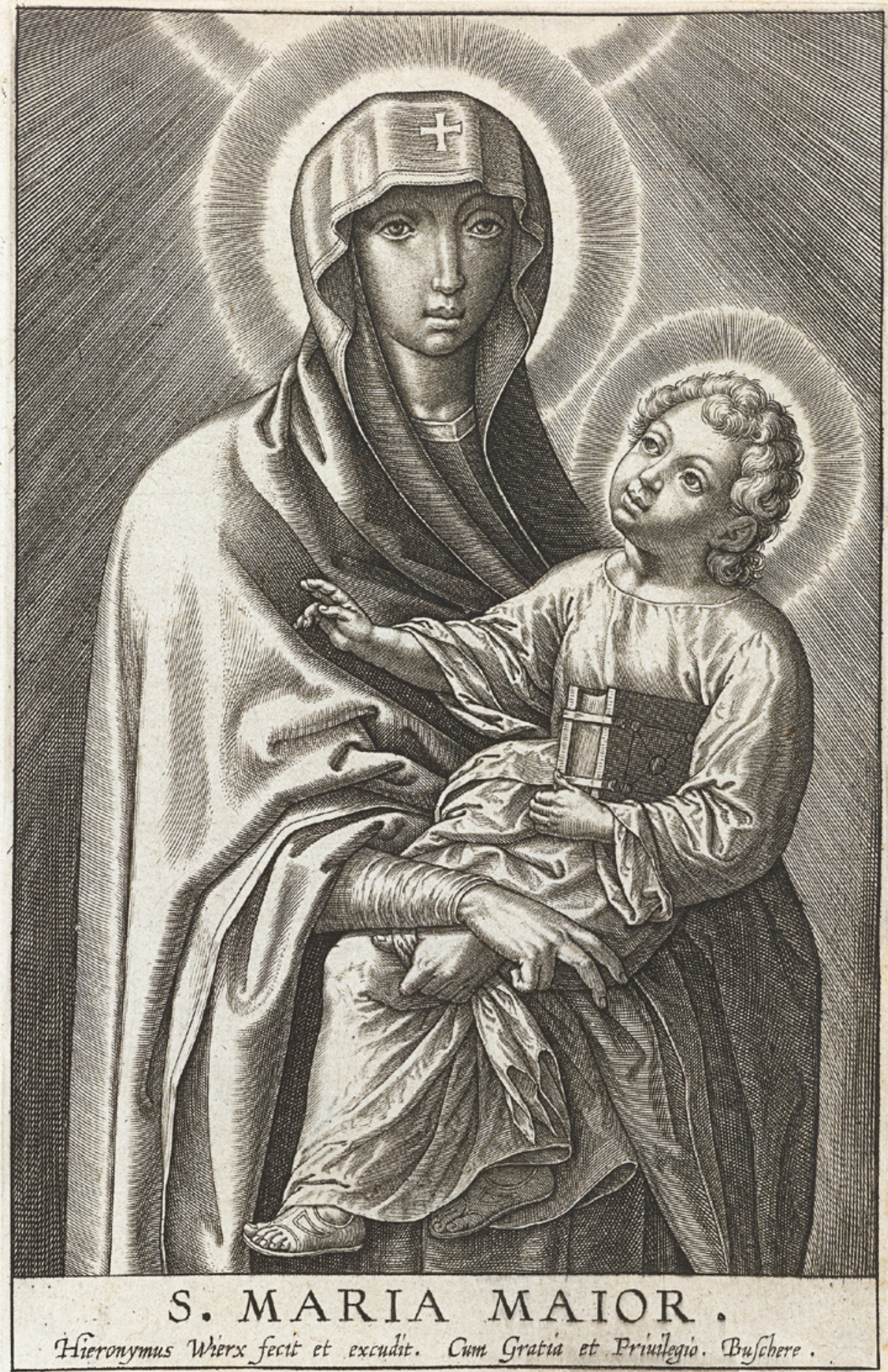

FIGURE 3.8 Hieronymus Wierix, Salus Populi Romani Madonna, before 16oo, engraving. Amsterdam, Rijksmuseum, Rijksprentenkabinet

PHOTO: (C) RIJKSMUSEUM 
unfolded in the practice of making - akin to the Ignatian approach familiar from the Spiritual Exercises, the Evangelicae historiae imagines, and the Imago primi saeculi Societatis Iesv - and they sanctioned the material flexibility in reproduction that would become a hallmark of the Salus Populi Romani Madonna's travels.

The fourth context, also part of how devotional art functioned, could be considered profoundly Ignatian, because networked images, like the Salus Populi Romani Madonna, focused on the citation of place: local, global, and in-between. This version was not a new copy per se, but simply a significant reframing of the original: Pope Paul V (1550-1621, r.1605-21) had the Salus Populi Romani Madonna moved within Santa Maria Maggiore, from the southwestern side of the central nave above the Porta Regina to the altar of his Cappella Paolina (January 27, 1613) (fig. 3.9). ${ }^{247}$ The Pauline reformatting of the Salus Populi Romani Madonna fixed what had been a long-standing mobile protagonist in the "Inchinata," when the image of Christ from the Basilica of St. John the Lateran bowed to the image of Mary from Santa Maria Maggiore and then together were ritually processed and ensconced side by side in the nave. After Borja's actions, "authentic copies" of the Salus Populi Romani Madonna extended the neighborhood santo viaggio (sacred journey) to encompass a virtual global circumnavigation while the original remained stationary in one location. The Salus Populi Romani Madonna was encased in a temple-like

Canisius, De Maria Virgine incomparabili et Dei genitrice sacrosancta libri quinque [Five books on Mary, incomparable Virgin and Most Holy Mother of God] (Ingolstadt: David Schneider, 1577), 697; Walter S. Melion, "Quae lecta Canisius offert et spectata Diu: The Pictorial Images in Petrus Canisius's De Maria Virgine of 1577/1583," in Early Modern Eyes, ed. Walter S. Melion and Lee Palmer Wandel, Intersections: Interdisciplinary Studies in Early Modern Culture 13 (Leiden: Brill, 2009), 207-66, here 262-65; Noreen, "Icon of Santa Maria Maggiore, Rome," 666.

247 The altar was begun $c .1606$ and consecrated on February 5, 1617, with the completion of the predella bringing the project to a close in December 1617. Steven F. Ostrow, Art and Spirituality in Counter-Reformation Rome: The Sistine and Pauline Chapels in S. Maria Maggiore (Cambridge: Cambridge University Press, 1996), 118-20, 125, 142-151; Gerhard Wolf, "Porta Regina, Cappella Ferreri und die Imagines supra Portam: Ein Ort und seine Bilder in Santa Maria Maggiore zu Rom," Arte medievale, 2nd series, 5, no. 1 (1991): 117-53. For reformatting in contemporary art, see David Joselit, After Art (Princeton: Princeton University Press, 2013), 55-59.

FIGURE 3.9 Girolamo Rainaldi, Pompeo Targone, and Antonio Tempesta (design); Camillo Mariani, Guillaume Berthelot, and Stefano Maderno (sculpture); Domenico Ferreri and Orazio Censore (bronze), Altar Tabernacle, c.16o6-17, marble, porphyry, jasper, lapis lazuli, gilt bronze, gold, silver. Rome, Basilica of Santa Maria Maggiore, Pauline Chapel PHOTO: (C) FOTO VASARI ROMA/ALESSANDRO VASARI (INV. NO. 04.1/2) 


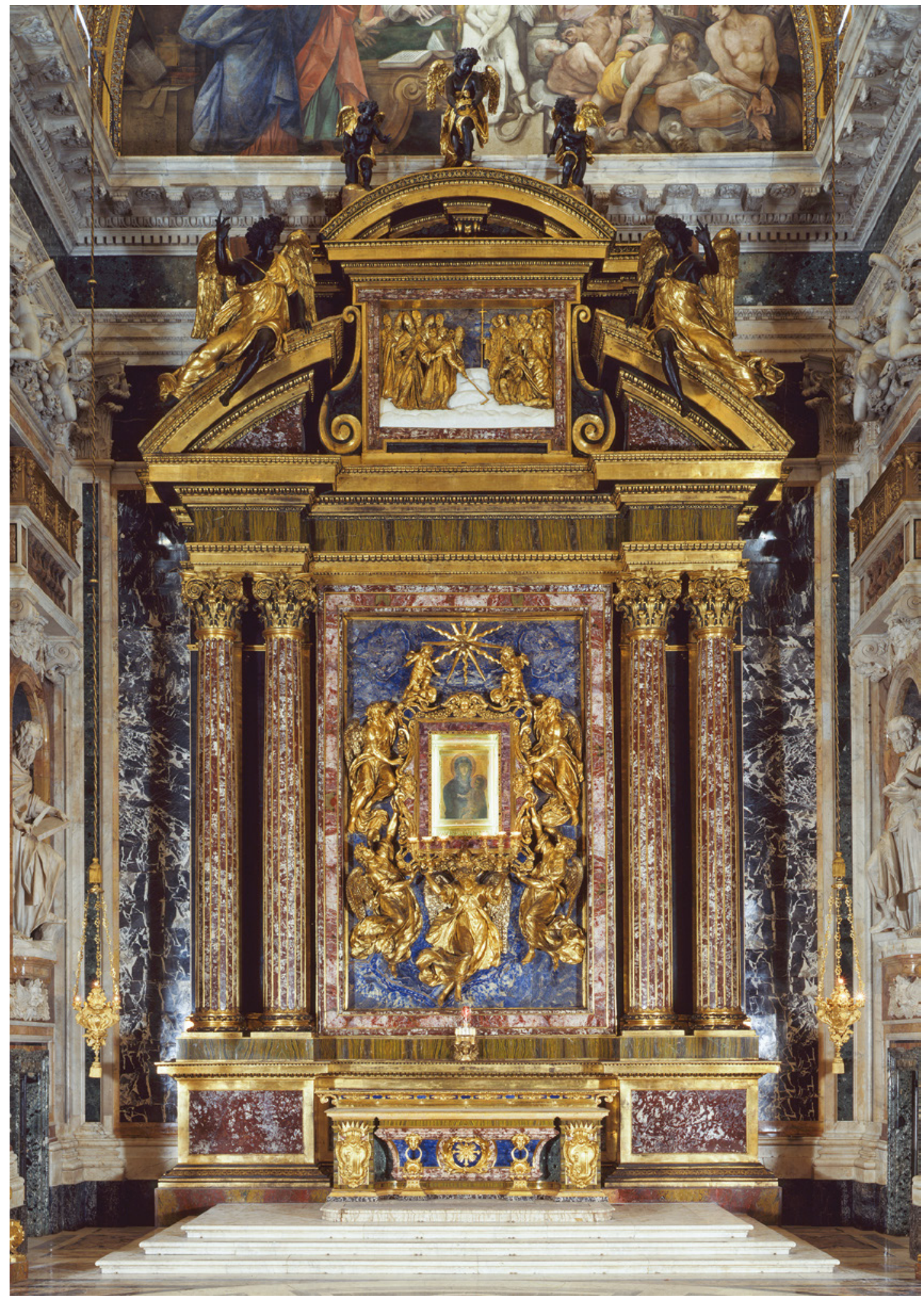


retable that staged the image as a venerable cult object and became a portal to another world, analogous to the elaborate architectural frontispieces of Jesuit books. ${ }^{248}$ Onofrio Panvinio (1529-68) stressed the dual roles of the Salus Populi Romani Madonna as icon ("imago") and relic ("reliquia") in his De praecipius urbis Romae, sanctioribusque, basilicis, quas septem ecclesias vulgo vocant (On the most excellent and holy basilicas of the city of Rome, which are commonly called the seven churches [Rome: Heirs of Antonio Blado, 1570]). ${ }^{249}$ And St. Ignatius noted the Council of Trent's accent on the relics of saints for "amending and reforming one's own life and state" (session 25, December 3, 1563) twice in his Spiritual Exercises (Spiritual Exercises, v. 189, 358). ${ }^{250}$ When the Salus Populi Romani Madonna was reframed as an image-tabernacle (Bildtabernakel), suspended on a mausoleum-esque wall mid-flight by a corona of golden angels, the experience of assumption could be simulated, allowing the image to operate as istoria and immagine, historical narrative and relic immemorial, in keeping with a Jesuit cosmology. ${ }^{251}$

The cultic associations of the Salus Populi Romani Madonna's Pauline reformatting were picked up by a Reliquary ad Tabula, now in the Museu de São Roque in Lisbon, that features a postcard-sized oil-on-copper version as the centerpiece of an elaborate receptacle for bones from nineteen saints (fig. 3.10).252 The Lisbon Reliquary was fashioned from the "Ceylon ebony" (Diospyros ebenum) native to southern India and Sri Lanka, redolent of the

248 Marc Fumaroli, "Sur le seuil des livres: Les frontispieces gravés des traités d'éloquence (1594-1641)," L'école du silence, 420-44, 635.

249 Noreen, "Icon of Santa Maria Maggiore, Rome," 672.

250 Fleming, Draw Me into Your Friendship, 144-45, 282-83; Fumaroli, "Sur le seuil des livres," 420-44, 635; Ganss, Spiritual Exercises of Saint Ignatius, 80, 134; Henry Joseph Schroeder, O.P., ed., The Canons and Decrees of the Council of Trent, rev. ed. (Charlotte, NC: TAN Books, 1978), 218-20.

251 Ostrow, Art and Spirituality in Counter-Reformation Rome, 152-67; Martin Warnke, "Italienische Bildtabernakel bis zum Frühbarock," Münchner Jahrbuch der bildenden Kunst 19 (1968): 61-102.

252 Mia M. Mochizuki, "The Reliquary Reformed," in "Art and Religious Reform in Early Modern Europe," Art History, Special Issue on the 5ooth Anniversary of the Lutheran Reformation, 40, no. 2, ed. Bridget Heal and Joseph Koerner (April 2017): 431-49; https:// doi.org/10.1111/1467-8365.12313 (accessed March 15, 2021); Maria Helena Oliveira et al., eds.,

FIGURE 3.10 Portuguese Artist, Reliquary ad Tabula with the Salus Populi Romani Madonna, second half of the seventeenth century, ebony, gilt bronze, colored glass, and oil painting on copper (inv. no. RL 1214). Lisbon, Museu de São Roque

(C) SANTA CASA DA MISERICÓRDIA DE LISBOA. PHOTO: JÚLIO MARQUES 


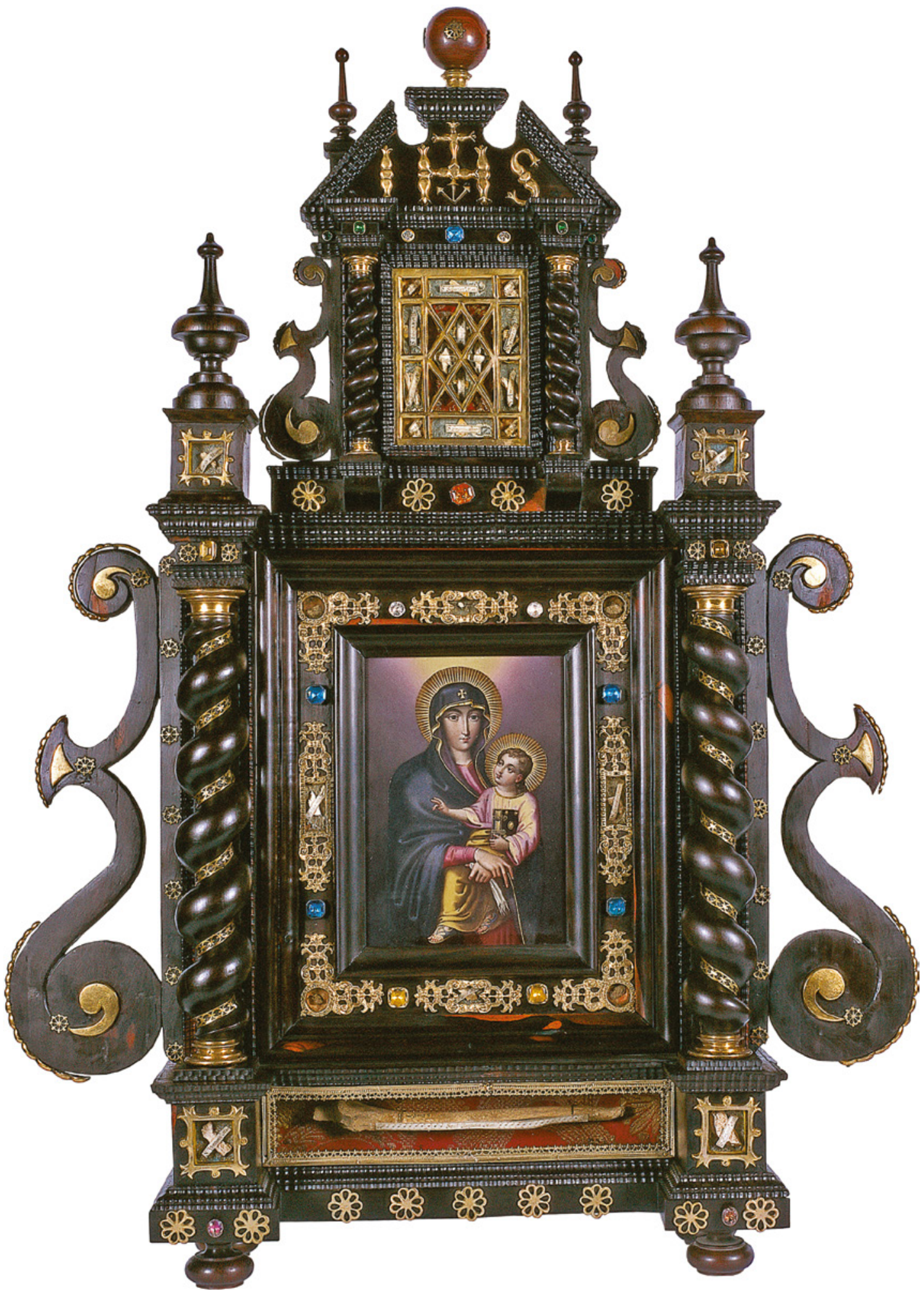


Portuguese eastern trade routes, and treasured for its distant origins and the difficulty involved in carving a hard wood. ${ }^{253}$ Ebony marshaled evidential and allegorical value to support the Salus Populi Romani Madonna's claims; like the original's new framing system, the use of this prestigious material predicated a shift to a system that could accommodate historical and symbolic value in a single object. Early modern "relics of contact," as opposed to popular late medieval "contact relics," drew on the composition and disjuncture of place found in Nadal's Evangelicae historiae imagines. What distinguished this copy of the Salus Populi Romani Madonna was the visible record of its return to European ground, where its foreign materials marked what Annelise Riles has called the "inherent recursivity" of a network commenting on itself. ${ }^{254}$ The excerpted souvenir of missions, rooted in the physical substance of the object, had come to usurp the position of the referential memoria in the imagined genesis of new worlds, and counter-intuitively, the farther a contact object migrated from its source, or the more local it became, the more genuine the authenticity of place materials made it appear to be. The end result was a networked image, which drew on its newest contexts to "reactivate" the aura of the icon, an early example of Walter Benjamin's (1892-1940) comment on copying in contemporary media, like photography, film, postcards, and now also applicable to video and digital art, where, "in permitting the reproduction to meet the beholder or listener in his own particular situation, it reactivates the object reproduced."255

\subsection{The Technological Image}

The ancient world is often celebrated for advances in pure mathematics and physics, but it was to innovations in applied mechanics and engineering by

Museum of São Roque, trans. Thomas E. Fisher (Lisbon: Santa Casa da Misericórdia de Lisboa, 2008), 153 .

253 Nadia Baadj, "A World of Materials in a Cabinet without Drawers: Reframing Jan van Kessel's The Four Parts of the World," in Meaning in Materials, 1400-180o, ed. Ann-Sophie Lehmann, Frits Scholten, and H. Perry Chapman, Nederlands Kunsthistorisch Jaarboek 62 (Leiden: Brill, 2012), 202-37, here 221-22.

254 Annelise Riles, The Network Inside Out (Ann Arbor: University of Michigan Press, 200o), 3, $6,172-73$.

255 Walter Benjamin, "Das Kunstwerk im Zeitalter seiner technischen Reproduzierbarkeit (Dritte Fassung)," Gesammelte Schriften, ed. Rolf Tiedemann and Hermann Schweppenhäuser, 8th ed. (Frankfurt am Main: Suhrkamp Verlag, 2017), 1, part 2:471-5o8, here 477; Benjamin, "The Work of Art in the Age of Mechanical Reproduction," Illuminations, ed. and trans. Hannah Arendt (New York: Schocken Books, 1969), 217-51, here 221; Benjamin, "The Work of Art in the Age of Reproducibility (Third Version)," Selected Writings, ed. Howard Eiland and Michael W. Jennings, trans. Edmund Jephcott et al. (Cambridge, MA: Harvard University Press, 2003), 4:251-83, here 254. 
men like Archimedes of Syracuse $(c .287-c .212$ BCE) and Hero of Alexandria $(c .10 \mathrm{CE}-c .70 \mathrm{CE})$ that Jesuits looked to realize a global sacred art. ${ }^{256}$ The prime example of making in a machine age, the creation of a technological image, was the Jesuit promotion of the printing press; in an emblem from the Imago primi saeculi Societatis Iesv, labeled Societas Iesv persecutionibus formatur (The Society of Jesus is given shape by persecutions), Jesuits even selfidentified with a printer (fig. 3.11). As the printer-Jesuit prepares to feed paper and plate through the roller press, select later stages of production-the six paper pictures hanging to dry in the background, the completed images posted on the press' frame- underscore the process of printmaking so well suited to Ignatian spirituality. The print was a fundamentally networked image, a cooperative effort often cited within the image itself: designs could be made by one artist (invenit or delineavit), after the work of a painter (pinxit), to be "carved" by an engraver (sculpsit); the plates to be printed (impressit) and issued by a publisher (excudit, divulgavit, apud, caelavit, formis, or the Dutch ten huyse van); the project often financed by another party (sumptibus); and sometimes organized under the management of someone else (direxit). ${ }^{257}$ No other order published as much as the Jesuits during this period, because the Constitutions of the Society of Jesus placed the obligation of an "apostolate of the pen" in its founding charter, where the authoring of edifying books was considered an active, pressing apostolic ministry, not merely an abstract ideal. ${ }^{258}$ Jesuit volumes were prized for their low price and accessibility; some books enjoyed individual runs of fifty thousand copies, and one catechism from 1607 had already been reprinted one hundred times by $1642 .{ }^{259}$ Antwerp became the home of not only Jesuit bestsellers, like the Evangelicae historiae imagines and the Imago, but also where at least six hundred prolific Jesuits serving in what

256 Eugenio Lo Sardo, ed., Iconismi e mirabilia da Athanasius Kircher, Tecnica Curiosa 2 (Rome: Edizioni dell'Elefante, 1999), 10-11, 59-61, 236-37, 273-74; Mochizuki, "Jesuit Visual Culture and the Machine Age," 449-86; Ingrid Rowland, The Divine Spark of Syracuse, Mandel Lectures in the Humanities (Waltham, MA: Brandeis University Press, 2019), 57-76; Arnold A. Witte, "Scale, Space, and Spectacle: Church Decoration in Rome, 150o1700," in A Companion to Early Modern Rome 1492-1692, ed. Pamela M. Jones, Barbara Wisch, and Simon Ditchfield (Leiden: Brill, 2019), 459-81, here 471-73.

257 Nadine M. Orenstein, Hendrick Hondius and the Business of Prints in SeventeenthCentury Holland, Studies in Print and Printmaking 1 (Rotterdam: Sound \& Vision, 1996), 14, 86-137; Ad Stijnman, Engraving and Etching, 1400-200o: A History of the Development of Manual Intaglio Printmaking Processes (Houten: Hes \& De Graaf Publishers, 2012), 76.

258 Begheyn, "Jesuits in the Low Countries and Their Publications," xxii; St. Ignatius of Loyola, Constitutions of the Society of Jesus, 284, part 7, chapter 4, entry 11 (653).

259 Marie Juliette Marinus, "Kampionen van de contrareformatie, 1562-1773," in Antwerpen en de Jezuïeten, 1562-2002, ed. Herman Van Goethem (Antwerp: UfSIA, 2002), 7-70, here 39. 


\section{LIBER QVART TS. SOCIETAS PATIENS. 57I}

\section{Societas IE S V perfecutionibus formatur.}

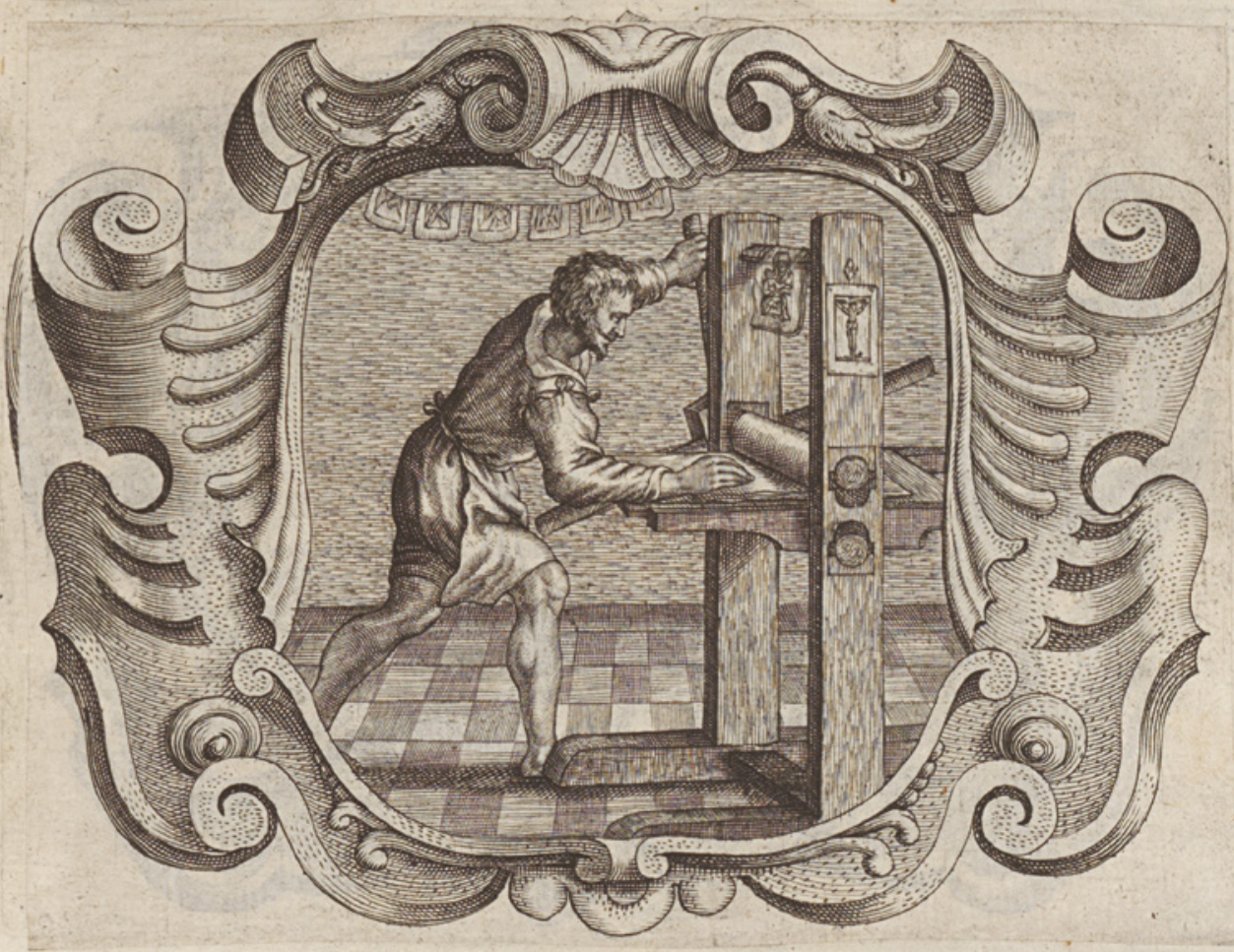

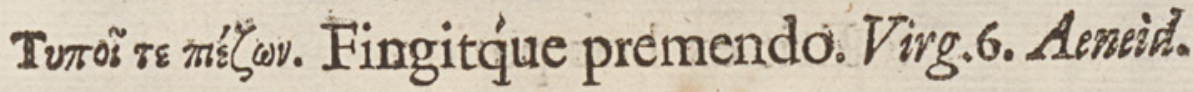

FIGURE 3.11 Andries Pauwels and Cornelis Galle, Societas Iesv persecutionibus formatur, in de Bolland and Henskens, eds., Imago primi saeculi Societatis Iesv, 571, engraving (call no. vB 8.556 C). Brussels, Bibliothèque Royale de Belgique, Rare Books PHOTO: (C) BIBLIOTHÈQUE ROYALE DE BELGIQUE

constitutes the Netherlands and Belgium today produced works on a greater range of topics than is often recognized. ${ }^{260}$ And it was the confluence of

26o Subjects of this remarkable outpouring included: the organization and history of the Society; religion (theology, exegesis, patristics, polemics, and catechesis); spirituality; politics; rhetoric (eloquence, poetry); literature; education; history; science; art; emblem books; and retorts to slander and persecution. Although the largest portion, just over 
publishing, international trade, and politico-religious worlds in this city that would inform the Society's decision to bring prints, and the printing press, to the world at large. ${ }^{261}$

The Societas Iesv persecutionibus formatur emblem particularly highlighted the Jesuit commitment to printing images: it features a roller press used to make intaglio images, and two finished prints-a Salus Populi Romani Madonna and a Crucifixion, the alpha and the omega of the passion narrative-imply the complete Christian pictorial compendium from "A" to "Z." In ancient Greece, Martin Heidegger (1889-1976) has noted, both technology and art-making were referred to as techne, because art "brought the dialogue of divine and human destinies to radiance," where "technē belongs to bringing-forth, to poiēsis" and the principle of "making in action" neatly accorded with the life of a "contemplative in action." 262 Jesuit art relied on machines to harness the transformative power of the imago agens, or "driving image," that thrust the bodying forth of ideals before the viewer and propelled Jesuit art into a global arena. ${ }^{263}$ The press was tied to the world from its inception; it was a world-machine, like the "máquina do mundo" that Luís Vaz de Camões (c.1524-80) devised to conclude his classic ballad, Os Lusíadas (The Lusiads [Lisbon: António Gonçalves, 1572]), and this association held a particular appeal for the theoretical underpinnings of an Ignatian charism and the praxis of their missions. ${ }^{264}$ The "world-making" of machines-the printing press as an instrument of scholarship, propaganda, and conversion-restructured the relationship between object and

one-third of around thirty thousand books (eleven thousand titles), covered theological topics, it is important to remember that nearly two-thirds, the lion's share, were on non-theological topics, which included arts and sciences (3,60o titles), literature (seven thousand titles), and history and geography (eight thousand titles). The exact number of books published by Jesuits in the Low Countries is difficult to pinpoint precisely, because authors were recorded by province, which could include Jesuits of other nationalities; and lists like the Bibliotheca Catholica Neerlandica Impressa are limited to "spiritual literature." Begheyn, "Jesuits in the Low Countries and Their Publications," xxii; Begheyn et al., Jesuit Books in the Low Countries 1540-1773.

261 Dekoninck, "Founding of a Jesuit Imagery," 341-47; Dekoninck, "Invention de l'image de la Compagnie de Jésus entre Rome et Anvers," 166-82; Fabre, Ignace de Loyola, 192-207.

262 Martin Heidegger, "Die Frage nach der Technik," Vorträge und Aufsätze (Pfullingen: Günther Neske, 1954), in Martin Heidegger, Gesamtausgabe: I. Abteilung; Veröffentlichte Schriften 1910-1976, Vol. 7 Vorträge und Aufsätze, ed. Friedrich-Wilhelm von Herrmann (Frankfurt am Main: Verlag Vittorio Klostermann, 200o), 5-36, here 12-14, 35; Heidegger, "The Question concerning Technology," The Question concerning Technology and Other Essays, trans. William Lovitt (New York: Harper \& Row, 1977), 3-35, here 10-13, 34.

263 De Boer, Enenkel, and Melion, Jesuit Image Theory.

264 Luís Vaz de Camões, The Lusiads, trans. Landeg White (Oxford: Oxford University Press, 1997), 212, canto 10, verse 79; Vaz de Camões, Os Lusíadas, ed. Emanuel Paulo Ramos, 3rd ed. (Porto: Porto Editora, 2006), 336, canto 10, verse 79. 
production, when a mode of information transmission became transformative for society, as in Régis Debray's cultural classification by "mediaspheres": the "logisphere" of script; the "graphosphere" of the printing press; the "videosphere" of television; and the present "hypersphere" of the computer. ${ }^{265}$ Much of the analysis of cross-cultural artistic exchange has focused on translation, but the printing press also provides a model with which to consider the appearance of objects neglected by textual paradigms and outcome-oriented approaches. After all, the historian Simon Ditchfield has proposed that it may well have been the physical portability and "tradability" of sacred objects that made Roman Catholicism's emergence as a world religion tenable. ${ }^{266}$ Techne instrumentalized topos, place and subject alike, where mechanized fabrication allowed self-description without words, a self-rhetoricizing ekphrasis by object that narrated making in its own terms to challenge the status quo. ${ }^{267}$

The appropriation of prints for the construction of subject matter can be traced in a Madonna of the Snow (Sancta Maria ad Nives or Yuki no Santa Maria) attributed to the Jesuit Niccolò School workshop in Japan and presently housed in the Twenty-Six Martyrs' Museum in Nagasaki (fig. 3.12). ${ }^{268}$ Painted on a small scroll, or kakemono, no bigger than the size of a hand, the scroll depicts a classic Madonna, reticent, fingers steepled in prayer as she gazes downward, her wavy chestnut hair contrasting with Japanese-style bee-stung lips and a beauty mark on her left cheek. The subject of the Madonna of the Snow is a conventional one: she is the Madonna who made it snow on a hot August night in Rome to indicate to Pope Liberius (310-66, r.352-66) where Santa Maria

265 Régis Debray, Media Manifestos: On the Technological Transmission of Cultural Forms, trans. Eric Rauth (London: Verso, 1996), 141-42, 171-74.

266 Simon Ditchfield, "Translating Christianity in an Age of Reformations," in Translating Christianity, ed. Simon Ditchfield, Charlotte Methuen, and Andrew Spicer (Cambridge: Ecclesiastical History Society, 2017), 164-95.

267 Niklas Luhmann, Art as a Social System (Stanford: Stanford University Press, 200o), 264; Peter McLaughlin, "Die Welt als Maschine: Der Genese des neuzeitlichen Naturbegriffs," in Macrocosmos in Microcosmo: Die Welt in der Stube; Zur Geschichte des Sammelns 1450 bis 180o, ed. Andreas Grote (Opladen: Leske und Budrich, 1994), 439-51.

268 Bailey, Art on the Jesuit Missions in Asia and Latin America, 75-76; Mia M. Mochizuki, "Seductress of Site: The Nagasaki Madonna of the Snow," in Aemulatio: Imitation, Emulation, and Invention in Netherlandish Art from 1500 to 1800; Essays in Honor of Eric Jan Sluijter, ed. Anton W.A. Boschloo et al. (Zwolle: Waanders, 2011), 76-88; Wakakuwa, Seibozō no tōrai, 174 .

FIGURE 3.12 Niccolò School, Madonna of the Snow, c.159o-1614, Japanese colors on paper, mounted on a hanging scroll. Nagasaki, Twenty-Six

Martyrs Museum

(C) TWENTY-SiX MARTYRS MUSEUM. PHOTO: RENZO DE LUCA, S.J. 


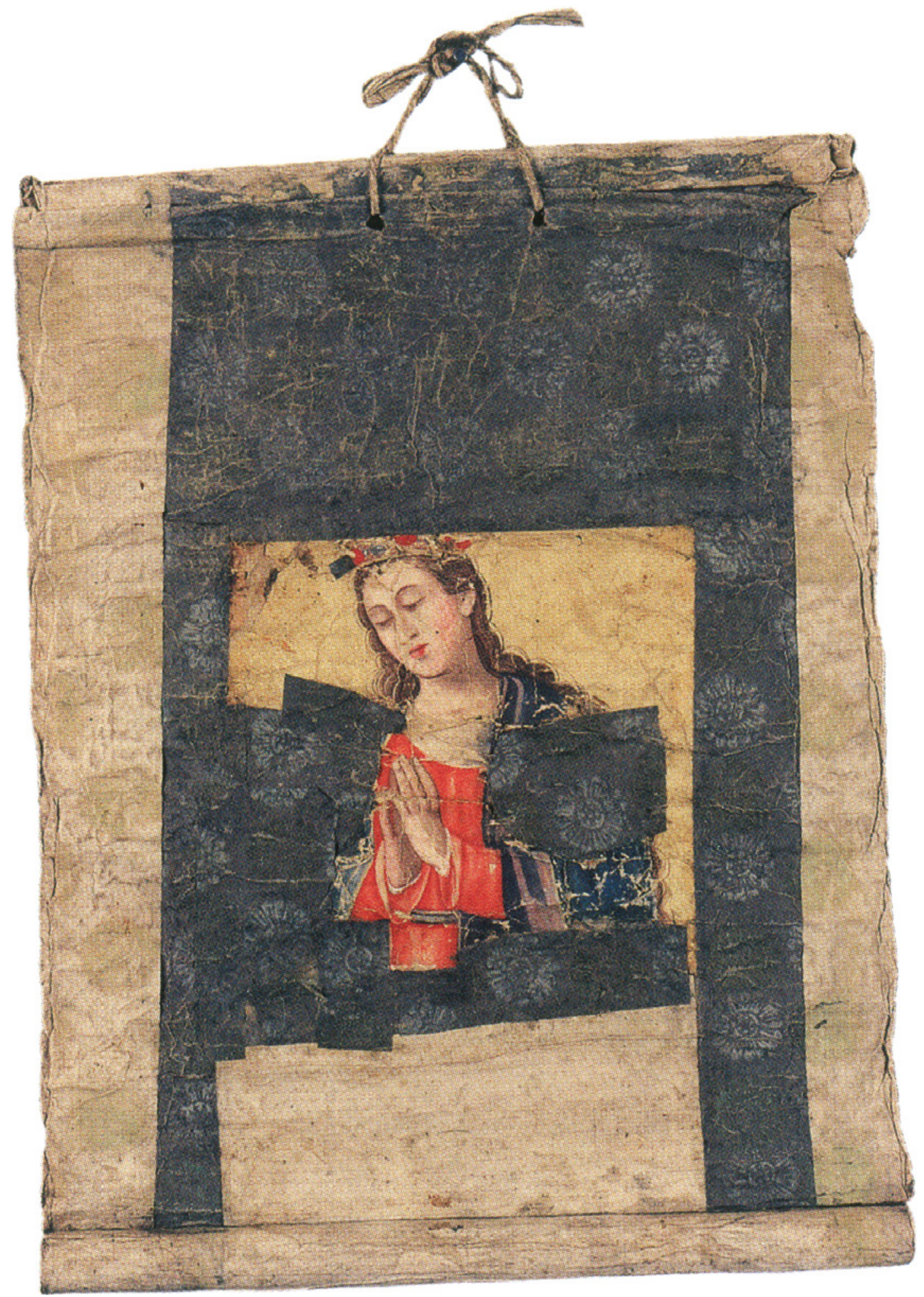


Maggiore should be built. ${ }^{269}$ But it is neither an obvious choice for a Madonna on mission, nor an immediately identifiable one, as the Nagasaki Madonna of the Snow looks nothing like two post-Tridentine representations of the Miracle of the Snow for Santa Maria Maggiore, which featured Pope Liberius with his entourage in snowy crowd scenes and Mary either as a distant vision or entirely absent. ${ }^{270}$ The Niccolò School artist did not look to earlier western renditions of the subject; instead, he preferred to combine a selection of printed Marian iconographies that may have been at hand. Perhaps the closest source for the angle of her inclined head and the unusual 1-2-1 arrangement of her fingers is the engraving of the Immaculate Conception with Instruments of the Laurentian Litany by Theodoor Galle named by Midori Wakakuwa (1935-2007) (fig. 3.13A). ${ }^{271}$ But the crown of red flowers, evoking the ring of twelve stars in the book of Revelation 12:1-2, is more akin to representations of this subject by Hieronymus Wierix, and the style of unbound hair falling over the shoulders and uncloaked head appear more frequently in assumption imagery (figs. $3.13 \mathrm{~B}-\mathrm{C}) .{ }^{272}$ The Nagasaki version of the Madonna of the Snow was enriched with the prophetic overtones of Mary's exemption from original sin in the immaculate conception and her triumphant coronation in the assumption, neither themes present in the Roman narrative. ${ }^{273}$ The implementation of a global art relied on the diffusion of prints, so images could be constructed on site by sampling, extracting, and re-assembling pictorial sources in an Ignatian application of the power of choice to picture-making.

A book entitled Tenchi hajimari no koto (The beginning of heaven and earth) charts the accrual of meaning to the story since its inception at Santa Maria Maggiore. ${ }^{274}$ In the hands of the Hidden Christians (Kakure or Senpuku

269 Michael Ott, "Our Lady of the Snow (Feast of)," in Herbermann et al., Catholic Encyclopedia, 11:361-62; Butler, Butler's Lives of the Saints, 3:265.

270 Both paintings stemmed from the Pauline patronage of Santa Maria Maggiore: Jacopo Zucchi's (c.1540-c.1596) Miracle of the Snow (c.1580, oil on canvas, Vatican City, Musei Vaticani, Pinacoteca Vaticana) was commissioned by Camillo Borghese, then archpriest of Santa Maria Maggiore, later Pope Paul v, on August 9, 1577; and Stefano Maderno's (c.1576-1636) relief, the Miracle of the Snow (c.1612-13, marble, Rome, Basilica of Santa Maria Maggiore, Pauline Chapel), was part of the Pauline reframing of the Salus Populi Romani Madonna (fig. 3.9). Ostrow, Art and Spirituality in Counter-Reformation Rome, $132-35,145-51$, figs. 102,125 .

271 Wakakuwa, Seibozō no tōrai, 175-76.

272 Mauquoy-Hendrickx, Estampes des Wierix, 1:82-83, 127-28, pl. 6o, 95, figs. 462, 707-8.

273 Louis Réau, Iconographie de l'art chrétien (Paris: Presses Universitaires de France, 195559), 1:457-65.

274 Tenchi hajimari no koto is a nineteenth-century record of an oral belief that began in the sixteenth century, so it should not be understood as a contemporaneous or verbatim source, although it can still provide a benchmark for how early modern Christianity 


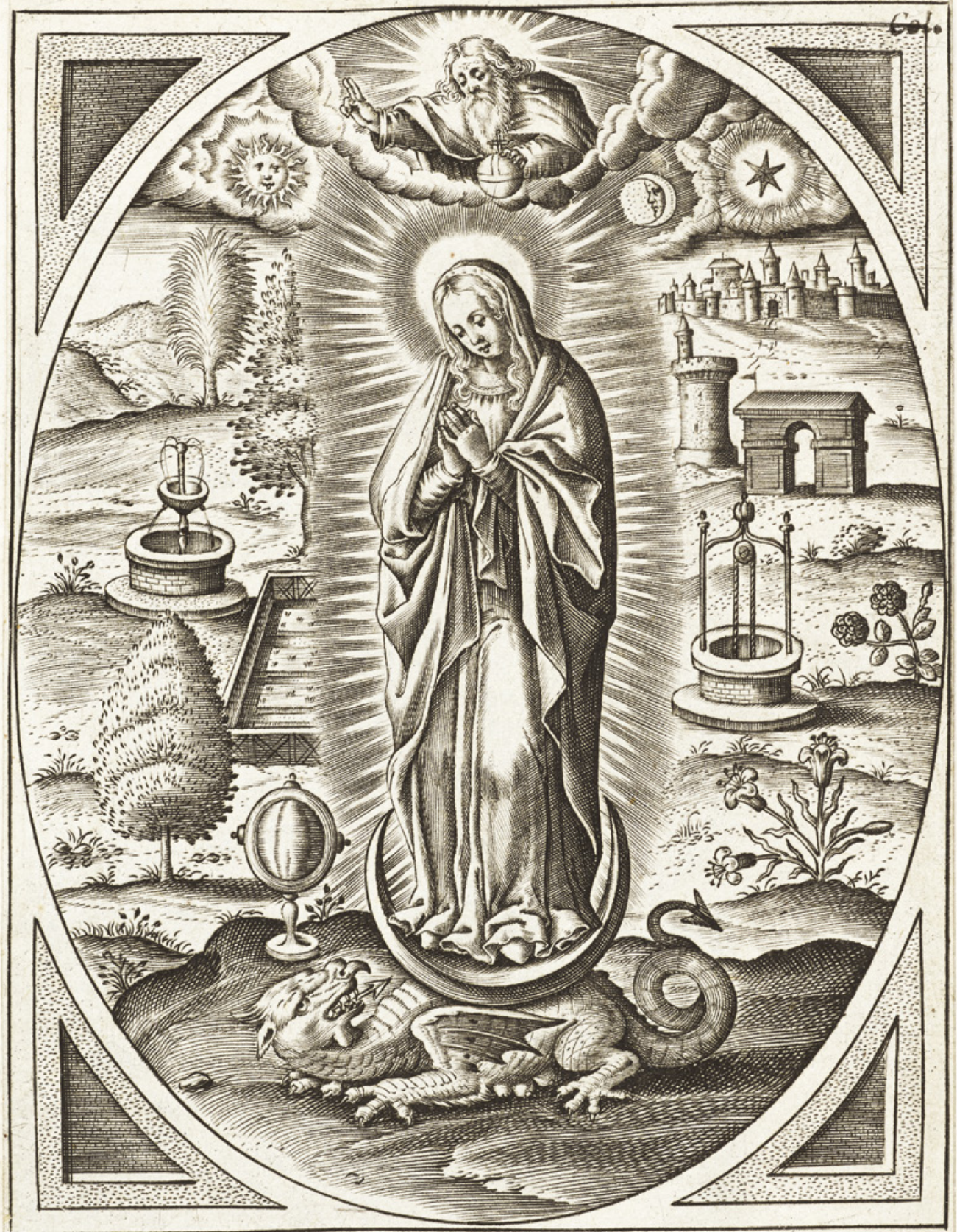

Tota pulchra es amica mea, et macula non eft in te. Cant.6. Theod. Galle excud.

FIGURE 3.13A Theodoor Galle, Immaculate Conception with Instruments of the Laurentian Litany, before 16oo, engraving (inv. no. 28113). Cologne, Wallraf-Richartz-Museum and Fondation Corboud, Graphic Arts Collection (C) RHEINISCHES BILDARCHIV COLOGNE (INV. NO. RBA_D054627). PHOTO: MARC WEBER 


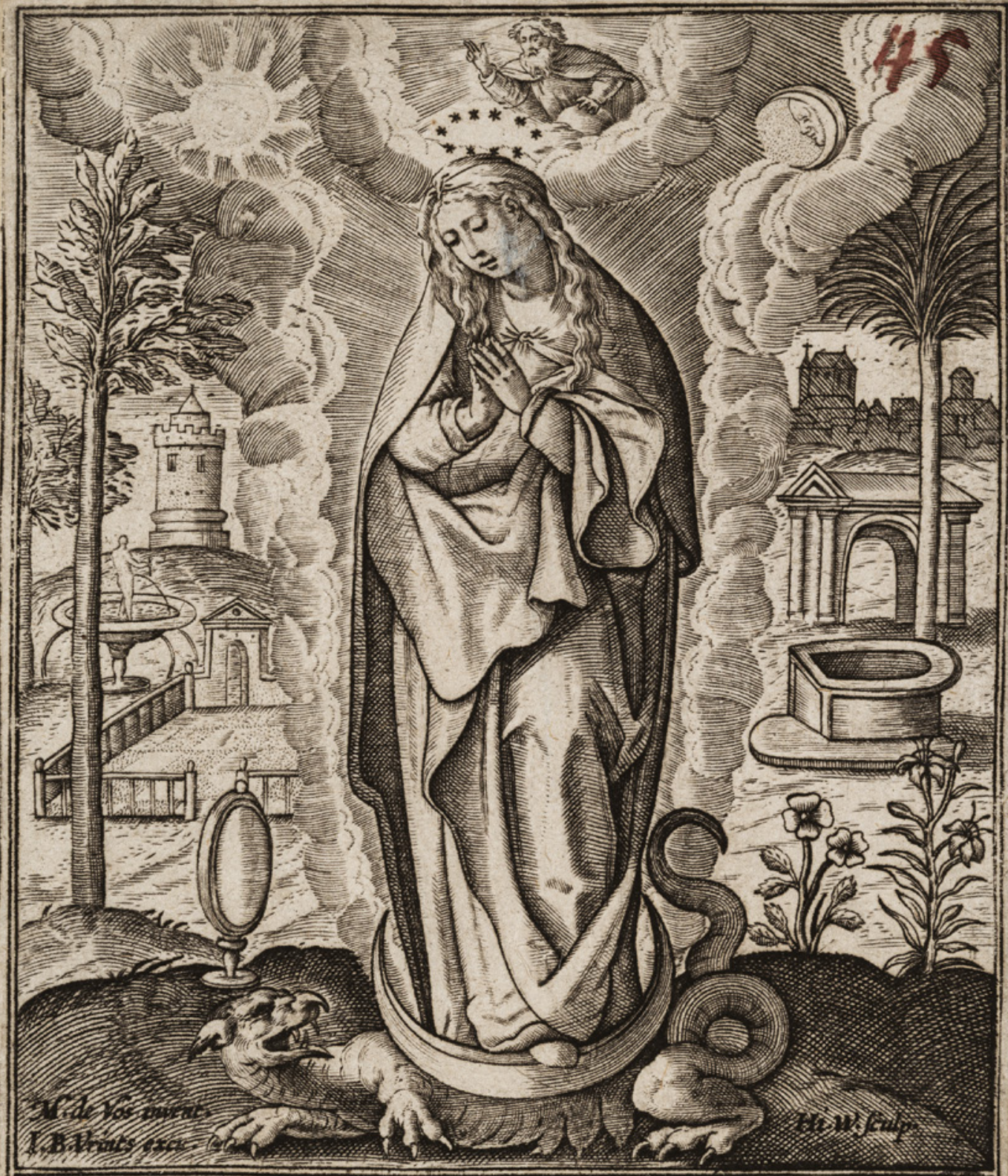

VIRGO PARENS DILECTA DEO, INVIDIOSA DRACON CHRISTICOLAS INTER TOTA DECORA NITES.W

\section{A $\quad 47745$}

FIGURE 3.13B Hieronymus Wierix (after Maerten de Vos), Immaculate Conception with Instruments of the Laurentian Litany, c.1577-1611, engraving (inv. no. A 47745). Dresden, Staatliche Kunstsammlungen, Kupferstich-Kabinett

(C) STAATLICHE KUNSTSAMMLUNGEN DRESDEN. PHOTO: ANDREAS DIESEND 


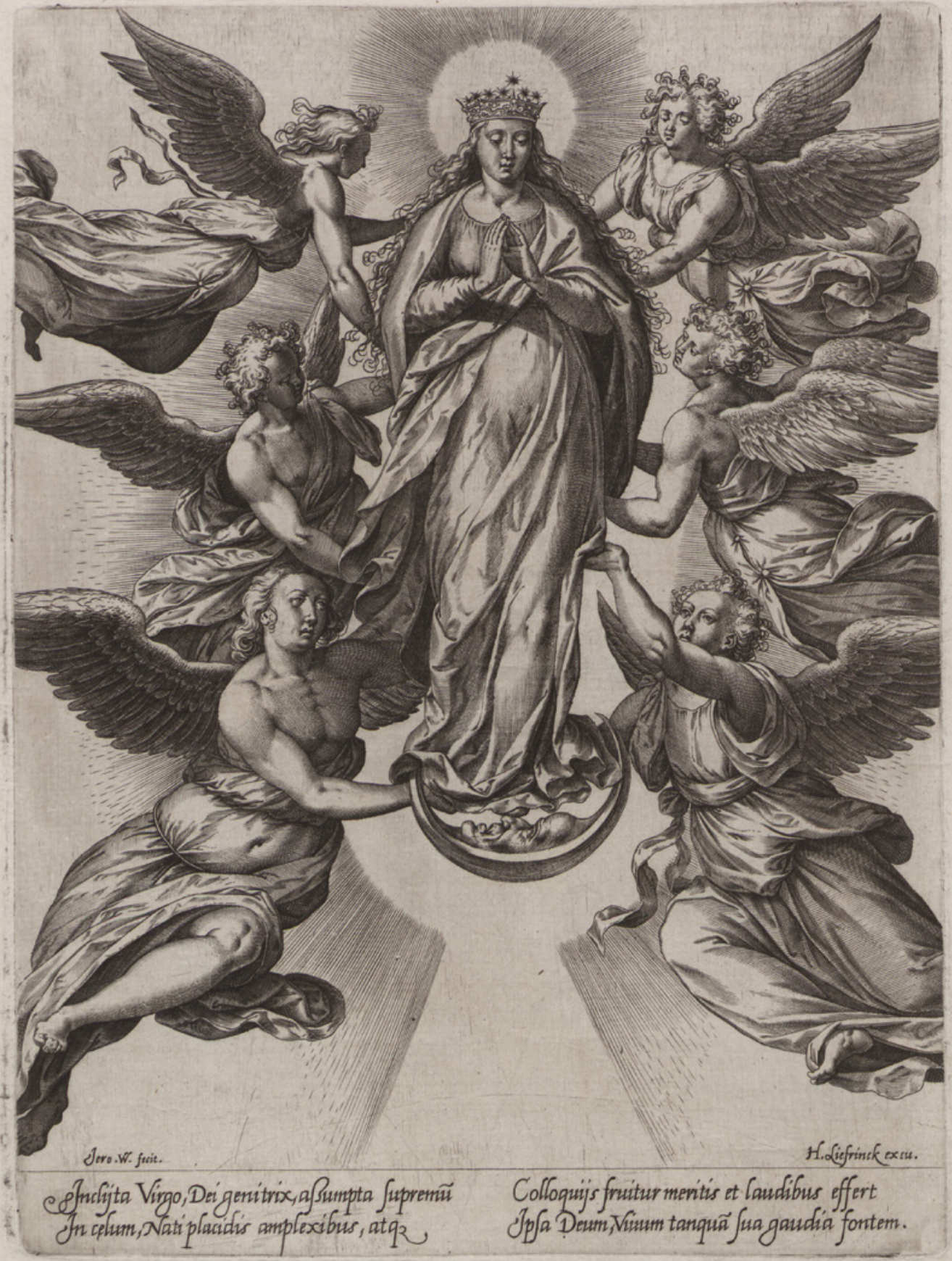

FIGURE 3.13C Hieronymus Wierix, Assumption of the Virgin, before 1573, engraving (call no. EST RES Fo_ Wierix-M.-H. 685-F 7163). Brussels, Bibliothèque Royale de Belgique, Prints and Drawings PHOTO: (C) BIBLIOTHÈQUE ROYALE DE BELGIQUE 
Kirishitan), who continued to practice Christianity in secret after it was completely banned in Japan, often at mortal risk to themselves and their families, a story about building logistics in Rome became an against-the-odds parable of local resistance. Mary performs a series of miracles, variations on western accounts, such as making snow appear in June and returning from heaven crowned with flowers and the title "Madonna of the Snow," to justify her rejection of the marriage proposal from the "King of Roson" in favor of a life of purity. ${ }^{275}$ Print-based composite objects, like the Madonna of the Snow, took a canonical subject, itself one that revolved around site selection, and compounded it with the exigencies of place, turning the capriciousness of reception into a virtue. If the networked image granted the "composition of place" amid changing circumstance, a print contributed "placelessness," "Ortlosigkeit" as Hans Körner dubbed it, or the disruption sought in the second half of Ignatian prayer. ${ }^{276}$ The case of the Nagasaki Madonna of the Snow was not exceptional; western printed images abounded in Japan. Frois requested image plates, a press, and a printer, first on December 13, 1584 and then again on January 1 , 1587 , to address the demand for more pictures, and with the arrival of a press in Japan, Jesuits were the first to circulate copper engravings of images and decorative vignettes in the country. ${ }^{277}$ The appropriation of multiple printed sources for a single subject was consistent with Aristotle's understanding of imitation as world-creating, a system that produces meaning aggregatively,

functioned in Japan, specifically the translation of the Roman Catholic Bible and magisterium into a Portuguese-Latin lexicon for a Japanese public. Alfred Bohner, "Tenchi hajimari no koto: Wie Himmel und Erde entstanden," Monumenta Nipponica 1, no. 2 (July 1938): 465514, here 474-76, 504-5; Ann M. Harrington, Japan's Hidden Christians (Chicago: Loyola University Press, 1993), 75-95; Christal Whelan, ed., The Beginning of Heaven and Earth: The Sacred Book of Japan's Hidden Christians (Honolulu: University of Hawai'i Press, 1996), 18-35.

275 The "King of Roson" could have been a reference to the King of Luzon, the largest island of the Philippines, where persecuted Japanese Christians sheltered. Christal Whelan has also suggested Hidden Christians may have identified with "Maruya"/Mary, as they too had been forced into a union with the Tokugawa regime despite their religious convictions. Harrington, Japan's Hidden Christians, 81-84; Whelan, Beginning of Heaven and Earth, 44-47, 85-91, n. 37 .

276 Hans Körner, Der früheste deutsche Einblattholzschnitt (Mittenwald: Mäander Kunstverlag, 1979), 4O; Lisa Pon, "Place, Print, and Miracle: Forli’s Madonna of the Fire as Functional Site," Art History 31, no. 3 (June 2008): 303-21; Pon, Printed Icon: Forli's Madonna of the Fire in Early Modern Italy (Cambridge: Cambridge University Press, 2015).

277 ARSI, Jap. Sin. 9-II, fols. $329^{\text {r-v }}$; 10-II, fols. $223^{\text {r-v }}$; Schütte, "Christliche Japanische Literatur," $258,261$. 
comparable to Gilles Deleuze's (1925-95) notion of "differential becoming."278 And the mimetic faculty, as a whole or in part, capitalized on location, be it Louis Marin's (1931-92) "place-making" that paralleled picture-making with a graphic naming especially apt in an age of discovery or Michael Taussig's anchoring of it to reception in contact zones. ${ }^{279}$ The lessons in replication from the Society's technologically derived composite objects present a case of Heidegger's conditional "en-framing," where the re-ordering of techne exposed the revelation latent within the worldly, and they recommend a much-needed counter-narrative to the apotheosis of the original. ${ }^{280}$

Japan provides a telling case of the rise and fall of the fortunes of mimetic reproduction on the high seas, not only because it hosted one of the most prolific and earliest Jesuit presses abroad, but also because it poses a fascinating example of a negative reception. ${ }^{281}$ The immaculate conception was a popular topic among Franciscans and Jesuits-Paul de Barry (1587-1661) claimed the Virgin told St. Alfonso Rodríguez (1533-1617) that she had created the Society to defend it - so the propagation of this doctrine where these orders' missionaries were active is to be expected, if the objects on which it is found are less predictable, like this small brass plaque in a zelkova (keyaki) wood frame (fig. 3.14). ${ }^{282}$ Close looking at its abraded surface reveals the figure of Mary standing on a crescent moon in a radiant aureole, in a posture reminiscent of the Madonna of the Snow, surrounded by a Franciscan

278 Gilles Deleuze, Difference and Repetition, trans. Paul Patton (New York: Columbia University Press, 1994), 70-128; Joselit, After Art, 55; Tom Huhn, in Dexter Dalwood et al., "Notes from the Field: Mimesis," Art Bulletin 95, no. 2 (June 2013): 19o-211, here 203; Alex Potts, in Dalwood et al., "Notes from the Field," 210.

279 Barbara Fuchs, Mimesis and Empire: The New World, Islam, and European Identities (Cambridge: Cambridge University Press, 2001); Huhn, "Notes from the Field," 204; Louis Marin, On Representation, trans. Catherine Porter (Palo Alto: Stanford University Press, 2001), 76, 262-68; Michael Taussig, Mimesis and Alterity: A Particular History of the Senses (New York: Routledge, 1993), 70-87, esp. 70.

280 Heidegger, "Frage nach der Technik," 24-33; Heidegger, "Question concerning Technology," 24-31.

281 Mochizuki, "Diaspora of a Jesuit Press," 113-34.

282 Illustrated Catalogue of Tokyo National Museum, 25, 159, 228-29, 232, fig. 1, inv. no. C711. At the advocacy of Peter Canisius and St. Robert Bellarmine (1542-1621), the Society of Jesus officially adopted the doctrine of the Immaculate Conception at the Fifth General Congregation (1593-94). Bridget Heal, The Cult of the Virgin Mary in Early Modern Germany: Protestant and Catholic Piety, 1500-1648 (Cambridge: Cambridge University Press, 2014), 200; "General Congregations"; https://jesuitportal.bc.edu/research/general -congregations/ (accessed March 15, 2021); Mâle, Art religieux de la fin du XVI siècle, du $X V I I^{e}$ siècle et du XVIII e siècle, 40-42; Martins, "Culto e devoção das igrejas dos jesuítas em Portugal," 107-8; Ostrow, Art and Spirituality in Counter-Reformation Rome, 239-40; Padberg, O'Keefe, and McCarthy, For Matters of Greater Moment, 198. 


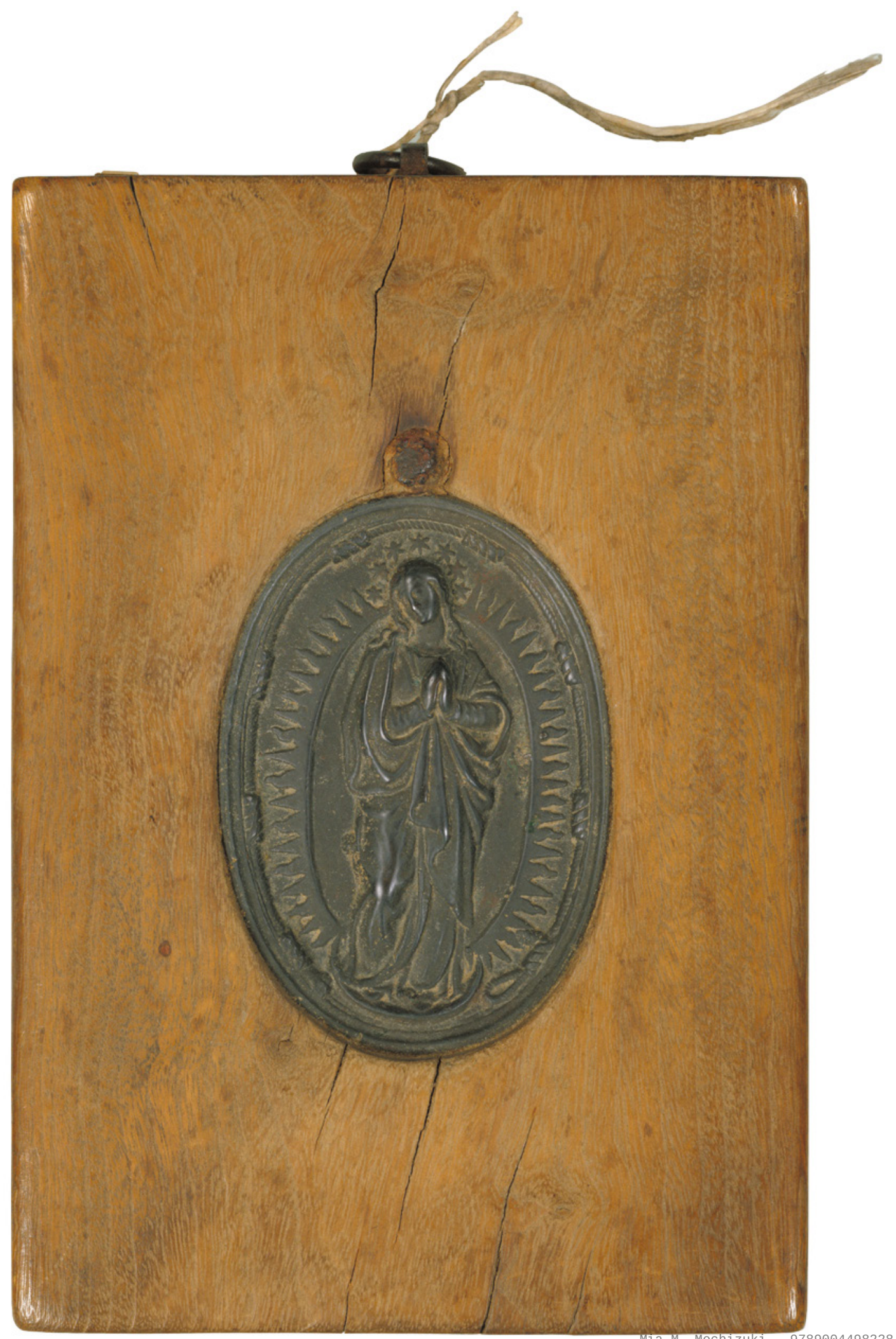


cincture, or cord. Printing plates and medallions of Christian subjects had sparked a new genre: fumi-e, low-relief brass plaques made to be stepped on in the performance of apostasy (e-fumi), a ceremony practiced from around 1629 through $1871 .{ }^{283}$ If the books, prints, and calendars from the Jesuit Press in Japan were largely burned, like the "mountain" of Jesuit publications at Nagasaki on July 23, 1626, its metal plates continued to live on in cynical burlesque, physically and conceptually reframed in the Heideggerian sense, to show how a critical resource for missionaries could be restructured to expel the very people responsible for it. ${ }^{284}$ When the image veered from devotion to desecration, fumi-e tablets became the matrices for a Christian mission, and its art, that would be formed through adversity and fashioned by pressure ("Societas Iesv persecutionibus formatur. / Typoî te piézon. Fingitque premendo. Virg. 6. Aeneid."), according to the Imago printing press emblem, whose poem elaborated: "Persecute, if you wish: in this / way a beautiful image is molded"

283 For a fumi-e relief that shares the rectangular shape used for print and plate, see European Artist, Our Lady of the Immaculate Conception Fumi-e, late sixteenth-early seventeenth century, brass, pine (matsu) wood frame (inv. no. C712). Illustrated Catalogue of Tokyo National Museum, 25, 159, 232, fig. 2, inv. no. C712. Kiichi Matsuda has noted the e-fumi practice first used images on paper during the Kan'ei era (1624-44), also supporting a connection with printmaking. Yakichi Kataoka, Fumie: Kinkyō no rekishi, NHK Bukkusu 9o, 2nd ed. (Tokyo: Nihon Hōsō Shuppan Kyōkai, 1977), 27; Thomas DaCosta Kaufmann, "10. Designed for Desecration: Fumi-e and European Art," Toward a Geography of Art (Chicago: University of Chicago Press, 2004), 303-40, here 308; Kaufmann, "Interpreting Cultural Transfer and the Consequences of Markets and Exchange: Reconsidering Fumi-e," in Artistic and Cultural Exchanges between Europe and Asia, 1400-1900: Rethinking Markets, Workshops, and Collections, ed. Michael North (Farnham: Ashgate, 2010), 135-62, here 143-44; Klaus Koschorke, Frieder Ludwig, and Mariano Delgado, eds., "II. Asia 16oo180o. A. Forms of Catholic Presence," A History of Christianity in Asia, Africa, and Latin America, 1450-1990: A Documentary Sourcebook (Grand Rapids, MI: William B. Eerdmans, 2007), 30-33, here 32-33; Kiichi Matsuda, "Fumie," Kokushi Daijiten (Tokyo: Yoshikawa Kōbunkan, 1979-97), 12:332-33; Mia M. Mochizuki, "Deciphering the Dutch in Deshima," in Boundaries and Their Meanings in the History of the Netherlands, ed. Benjamin J. Kaplan, Marybeth Carlson, and Laura Cruz (Leiden: Brill, 2009), 63-94, here 67-74; Takau Shimada and Yuriko Shimada, Fumie: Gaikokujin ni yoru fumie no kiroku (Tokyo: Yūshōdō Shuppan, 2007), 3, 24 .

284 Daniello Bartoli, Dell'historia della Compagnia di Giesù: Il Giappone, seconda parte dell'Asia (Rome: Ignazio de' Lazzari, 166o), 276; Johannes Laures, s.J., Kirishitan Bunko: A Manual of Books and Documents on the Early Christian Mission in Japan, rev. ed. (Tokyo: Sophia University Press, 1957), 100, n. 308; Joseph F. Moran, The Japanese and the Jesuits: Alessandro Valignano in Sixteenth-century Japan (London: Routledge, 1993), 145, n. 1.

$\leftarrow \quad$ FIGURE $3.14 \quad$ European Artist, Our Lady of the Immaculate Conception Fumi-e, late sixteenth-seventeenth century, brass, zelkova (keyaki) wood frame (inv. no. C711). Tokyo, Tokyo National Museum PHOTO: () TNM IMAGE ARCHIVES 
("Thlîbe dêpou, eikòn / houtôs hôráia prôtypôsetai.") (fig. 3.11)..25 The weaponizing of mimesis seen in the imitation of printing plates to make fumi-e reliefs testifies to some of the less palatable roles this mode of reproduction has played in cultural contact, one that for other times and places Deleuze has equated with seditious dispossession and disguise, Jacques Lacan (1901-81) has compared to the camouflage of warfare, and Homi Bhabha has famously represented as "subversive colonial mimicry."286 This was not simply the simulated iconoclasm of treading on images; it should also be understood as an expression of the limits of iconographic exchange in cross-cultural contexts.

Yet there was another chapter in the saga of the Christian print abroad, and the Niccolò School, despite being in exile, resisted having their tools of conversion wielded against them. An unusual representation of the Archangel St. Michael, $c .1614-38$, survives that has been attributed to the Sino-Japanese painter Jacopo Niwa (or Ni Yichen, d.1638) of the Niccolò School, painted after the workshop's enforced relocation to Macau in 1614, most likely for the Jesuit Church of the College of St. Paul (fig. 3.15A). ${ }^{287}$ Iconographic convention typically shows St. Michael slaying a dragon, the armored Christian knight about to drive a spike through the head of the malevolent creature squirming below his sandaled foot, as in an engraving by Hieronymus Wierix, St. Michael Triumphing over the Dragon (fig. $3.15 \mathrm{~B}$ ). ${ }^{288}$ Niwa borrowed the general composition from the Wierix print, but in the transmission from print to painting, St. Michael's shield was replaced by a luminous crucifix-topped monstrance, whose staff-like golden chain offered support as his boot rests on a gray plaque, which Clement

285 Virgil's Aeneid extended the analogy of person and print shaped through pressure by referencing Apollo's imprinting of the Cumaean Sibyl's body and soul: "But the prophetess, not yet brooking the sway of Phoebus, storms wildly in the cavern, if so she may shake the mighty god from her breast; so much the more he tires her raving mouth, tames her wild heart, and moulds her by constraint." Jean de Bolland and Godfried Henskens, eds., Imago primi saeculi Societatis Iesv (Antwerp: Plantin Press under Balthasar Moretus, 1640), 571; Dekoninck, "Passion des images," 54-56; Frederick M. Keener, ed., Virgil's Aeneid: Translated by John Dryden (London: Penguin, 1997), 152, book 6, lines 120-25; Mochizuki, "Diaspora of a Jesuit Press," 130-32; O'Malley, Art, Controversy, and the Jesuits, 6o6-7; Virgil, Eclogues, Georgics, Aeneid I-VI, trans. H. Rushton Fairclough, rev. G.P. Goold, Loeb Classical Library 63, rev. ed. (Cambridge, MA: Harvard University Press, 1999), 538-39, book 6, lines 77-8o.

286 Homi Bhabha, The Location of Culture (London: Routledge, 1994), 122, 126-28; Deleuze, Difference and Repetition, 70-128; Jacques Lacan, The Seminar of Jacques Lacan: Book XI; The Four Fundamental Concepts of Psychoanalysis, ed. Jacques-Alain Miller, trans. Alan Sheridan (New York: W.W. Norton, 1998), 99.

287 Jacopo Niwa was admitted to the Society in 1601. Bernard-Maître, "Art chrétien en Chine du temps du Père Matthieu Ricci," 220-24.

288 Mauquoy-Hendrickx, Estampes des Wierix, 2:224, pl. 166, fig. 1263. 


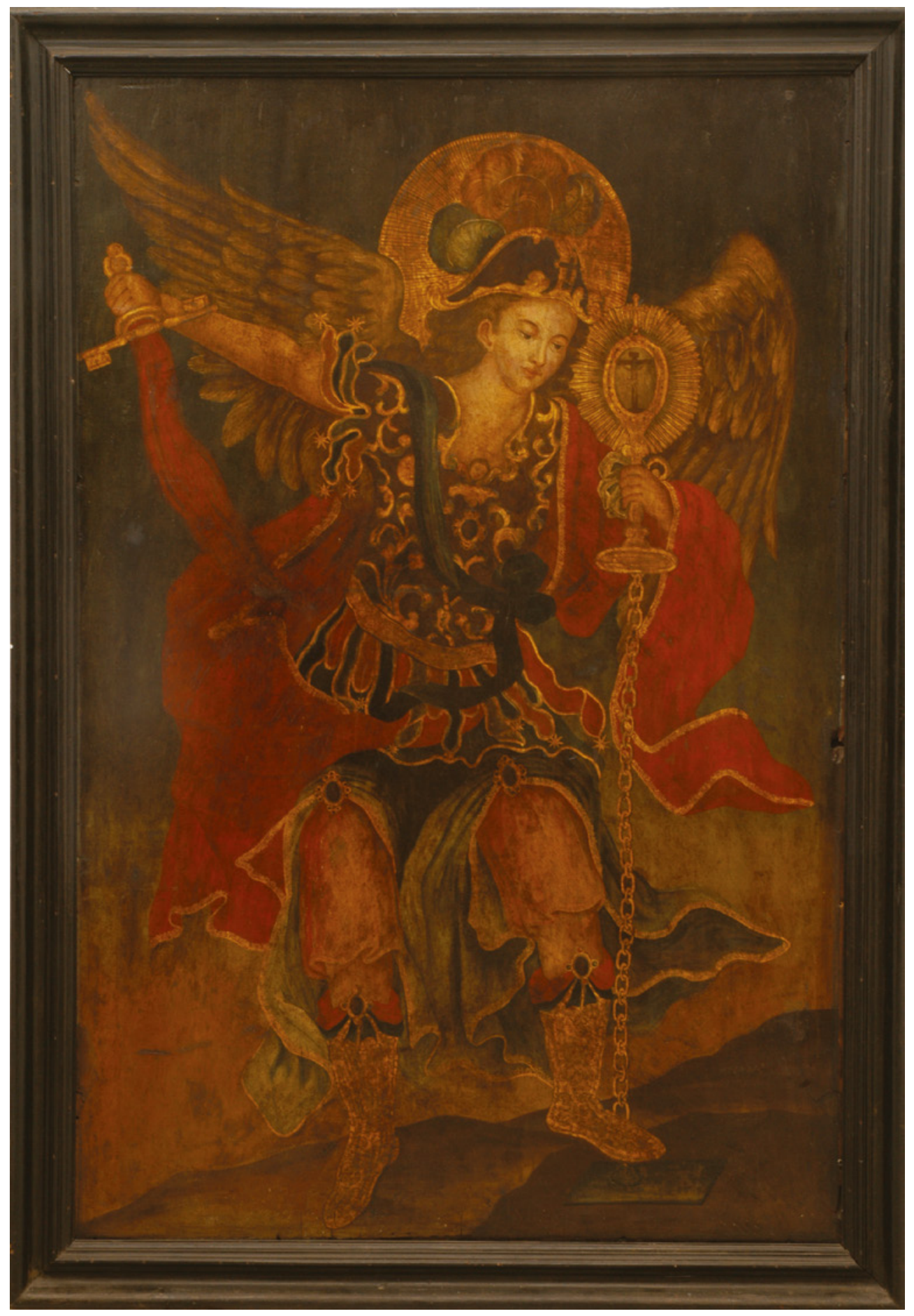

FIGURE 3.15A Jacopo Niwa (attributed), The Archangel St. Michael, c.1614-38, oil on panel (inv. no. P13). Macau, Museum of the Ruins of St. Paul (Museum of Sacred Art and Crypt)

PHOTO: (C DIOCESE OF MACAU, ST. JOSEPH'S SEMINARY, DIOCESAN OFFICE OF HISTORICAL ARCHIVES AND PATRIMONY, DEPARTAMENTO DIOCESANO DE ARQUIVO HISTÓRICOS E PATRIMÓNIO CULTURAL (DDAHPC) 


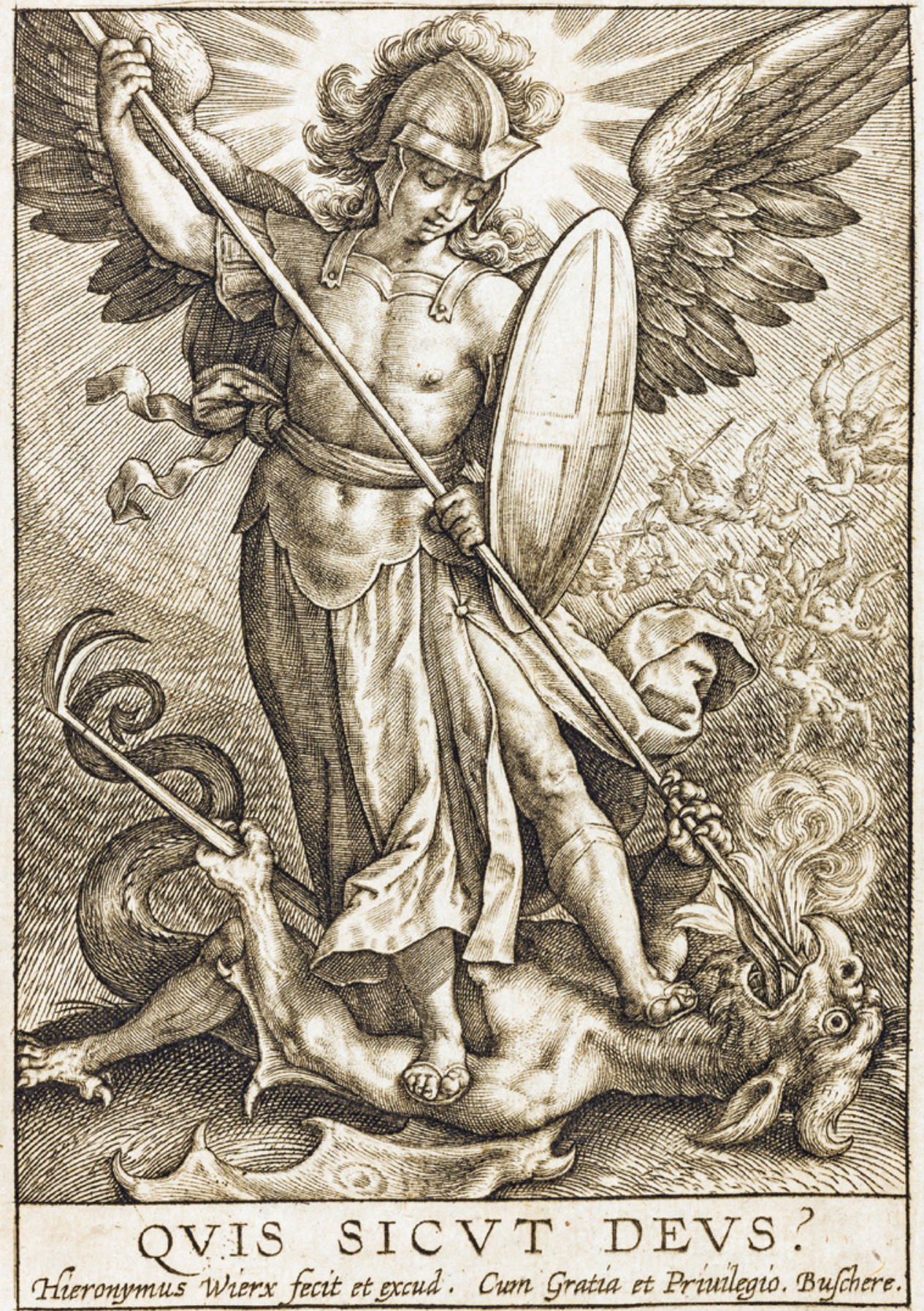

FIGURE 3.15B Hieronymus Wierix, St. Michael Triumphing over the Dragon, before 1619, engraving (call no. EST $8^{\circ}-$ Wierix-M.-H. 1263-S.IV 4012). Brussels, Bibliothèque Royale de Belgique, Prints and Drawings

PHOTO: (C) BIBLIOTHÈQUE ROYALE DE BELGIQUE 


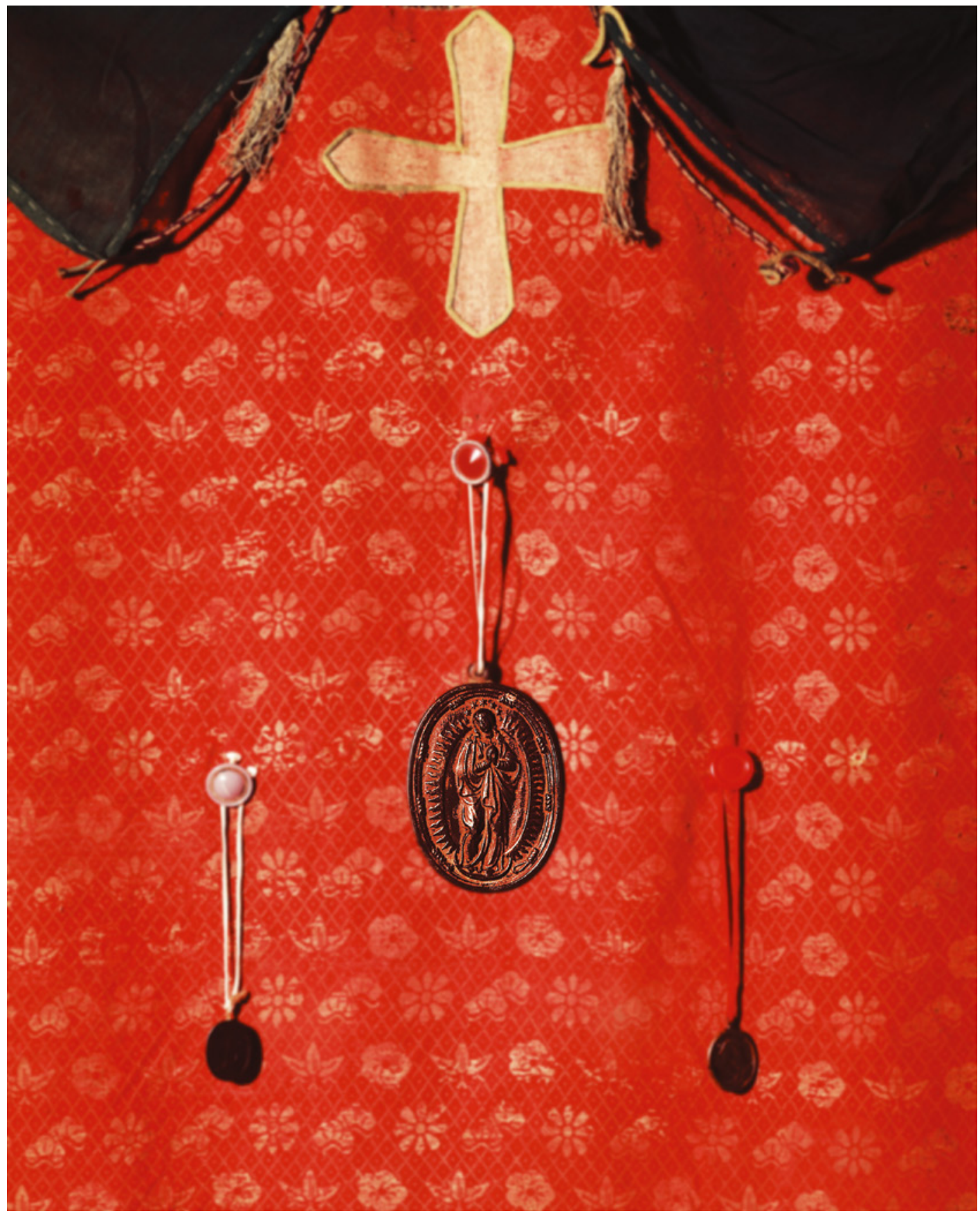

FIGURE 3.16 Our Lady of the Immaculate Conception Fumi-e plaques in Japanese Hidden Christian altars, Ikitsuki Island, $c .1999$

(C) MISAWA PHOTO LIBRARY INC. PHOTO: TADASHI NAKAJYO 
Onn has identified as a fumi-e tablet. ${ }^{289}$ In a rejoinder to the e-fumi ritual, Niwa appropriated the gesture of abjuration to express Christianity's own condemnation of such a practice. Inversion was itself subverted, as the fumi-e relief became the "monstrous double" to the devotional print, in René Girard's (1923-2015) terms, an object betrayed through its likeness, like the quandary of humankind, who must reckon with the engraving's question of "Who is like God?" ("Qvis sicvt Devs?") in the high stakes of semblance. ${ }^{290}$ The painting of The Archangel St. Michael was not alone in its refusal to forswear Christian art; fumi-e plaques were also worshiped at the illicit altars of Hidden Christian homes, valued all the more, from an Ignatian perspective, for being salvaged from a history of desecration that entwined their post-production journey through the world with inquisition, torture, and martyrdom (fig. 3.16). The tools of Christian printmaking had become relics in their own right and could be "baptized" with "San Juan-sama" holy water, wrapped in an ornately brocaded silk robe, and honored with emeritus ("goinkyō-sama") status. ${ }^{291}$ In trans-cultural mimetic reproduction, where a machine curtailed the exclusive reign of the hand in picture-making, the print diaspora could be reinterpreted for paintings, recast as the metal plates of repudiation, and repurposed as relics of Christian suffering.

The final iteration of the western printed image at the farthest points of the early modern world was a ghostly excerpt from the afterlife of images like Hieronymus Wierix's Crucifixion with Our Lady and St. John (figs. 3.17A-B). ${ }^{292}$ The projection of an image, one that recalled the trauma to the Christian devotional image in Japan, preserved the experience of bearing visual witness to suffering in the print's citation of Lamentations 1:12: "See if there is any sorrow like my sorrow" ("Videte si est dolor sicut dolor meus."). A mirror cast the dematerialized print onto a wall, as shown here, its subject matter and pictorial

289 Bailey, Art on the Jesuit Missions in Asia and Latin America, 77; Clement Onn, "Christianity in Japan, 1549-1639," in Christianity in Asia: Sacred Art and Visual Splendour, ed. Alan Chong, exh. cat. (Singapore: Asian Civilisations Museum, 2016), 170-83, here 177. For more on the global iconography of St. Michael, see Thomas DaCosta Kaufmann, "Mastery or Mestizaje? Placing an Interpretation of the Façade of San Lorenzo, Potosí," Toward a Geography of Art, 272-99; Stephanie Porras, "Going Viral? Maerten de Vos's St. Michael the Archangel," in Netherlandish Art in Its Global Context, ed. Thijs Weststeijn, Eric Jorink, and Frits Scholten, Nederlands Kunsthistorisch Jaarboek 66 (Leiden: Brill, 2016), 54-78.

290 René Girard, The Scapegoat, trans. Yvonne Freccero (Baltimore: Johns Hopkins University Press, 1989); Girard, Violence and the Sacred, trans. Patrick Gregory (Baltimore: Johns Hopkins University Press, 1979).

291 Tadashi Nakajyo and Kenichi Tanigawa, Kakure Kirishitan no seiga (Tokyo: Shōgakkan, 1999), 104-7, 130-32, 137; Tagita, Showa jidai no Senpuku Kirishitan, 342-43, pl. after 354.

292 Mauquoy-Hendrickx, Estampes des Wierix, 1:49-5o, pl. 44, fig. 35 o. 
antecedents demarcated by only the haziest of outlines. These ethereal devotional images, half-way between object and vision, were the result of what has been called a "magic mirror," or makyō, a type of object found among Hidden Christian communities in Japan mainly from the second half of the seventeenth century through the nineteenth century, although several families continue to make them today. Mirrors featured prominently in Jesuit circles, since their physical properties were well suited to demonstrate the conceptual ambiguities of mimetic representation. They populate the Imago's emblems: the "Omnibus omnia" interior of the Societatis operarij scene, where the reflection of the variety of humankind expressed divine love; and Archimedes's defense of Syracuse in Ignatius è cathedrâ diuini amoris igne concionem inflammat (Ignatius from his chair inflames the sermon with the fire of divine love), where the instrumentation of sacred truth operated much like a makyös surface (figs. 2.27, 3.18). ${ }^{293}$ The latter vignette depicts the unlikely hero in a waterside fortress, who saves his city by simply raising a mirror to convert a beam of light into a laser capable of igniting a marauding ship. Archimedes's inventive tactics acted as an analogy for the passionate faith of St. Ignatius in the emblem's title, supplying more tools with which to "go forth and set the world on fire" (Ite inflammate omnia."). The technological interventions of press and mirror became the favored material intermediaries between man and God, and the privileged means of broadcasting the tidings of God's love around the world.

In this mode of disruption, the mechanics of "mirror images" abrogated the most basic assumption of imagery: that it be visible to the naked eye. The makyo appeared to be a normal mirror, with a polished, reflective front and a low-relief pastoral scene, such as a crane among trees, on the reverse (fig. 3.19). Its secret image was invisible for much of the object's existence; for as long as the devotional projection could not be seen, its owner could not be accused of harboring Christian sympathies during an inspector's visit. The "magic" lay in the fact that the image was cast and carved in relief, much like a copper plate for an engraving, but now submerged beneath a smooth metal veneer.

293 De Bolland and Henskens, Imago primi saeculi Societatis Iesv, 718; O'Malley, Art, Controversy, and the Jesuits, 634-35. The story of Archimedes's defense of Syracuse was also included in the third mirror, the burning mirror ("Specvlvm vrens.") of David, Duodecim specula aliquando videre desideranti concinnata, and the Frontispiece of Athanasius Kircher's Ars magna lucis et umbrae [The great art of light and shadow] (Rome: Hermann Scheus and Ludovico Grignani, 1646) relied upon the same technology. Koen Vermeir, “Athanasius Kircher's Magical Instruments: An Essay on 'Science,' 'Religion,' and Applied Metaphysics (1602-1680)," Studies in History and Philosophy of Physics 38, no. 2 (2007): 363-40o; Vermeir, "Mirror, Mirror, on the Wall: Aesthetics and Metaphysics of 17thCentury Scientific/Artistic Spectacles," Kritische Berichte 32, no. 2 (2004): 27-38, here 35. 


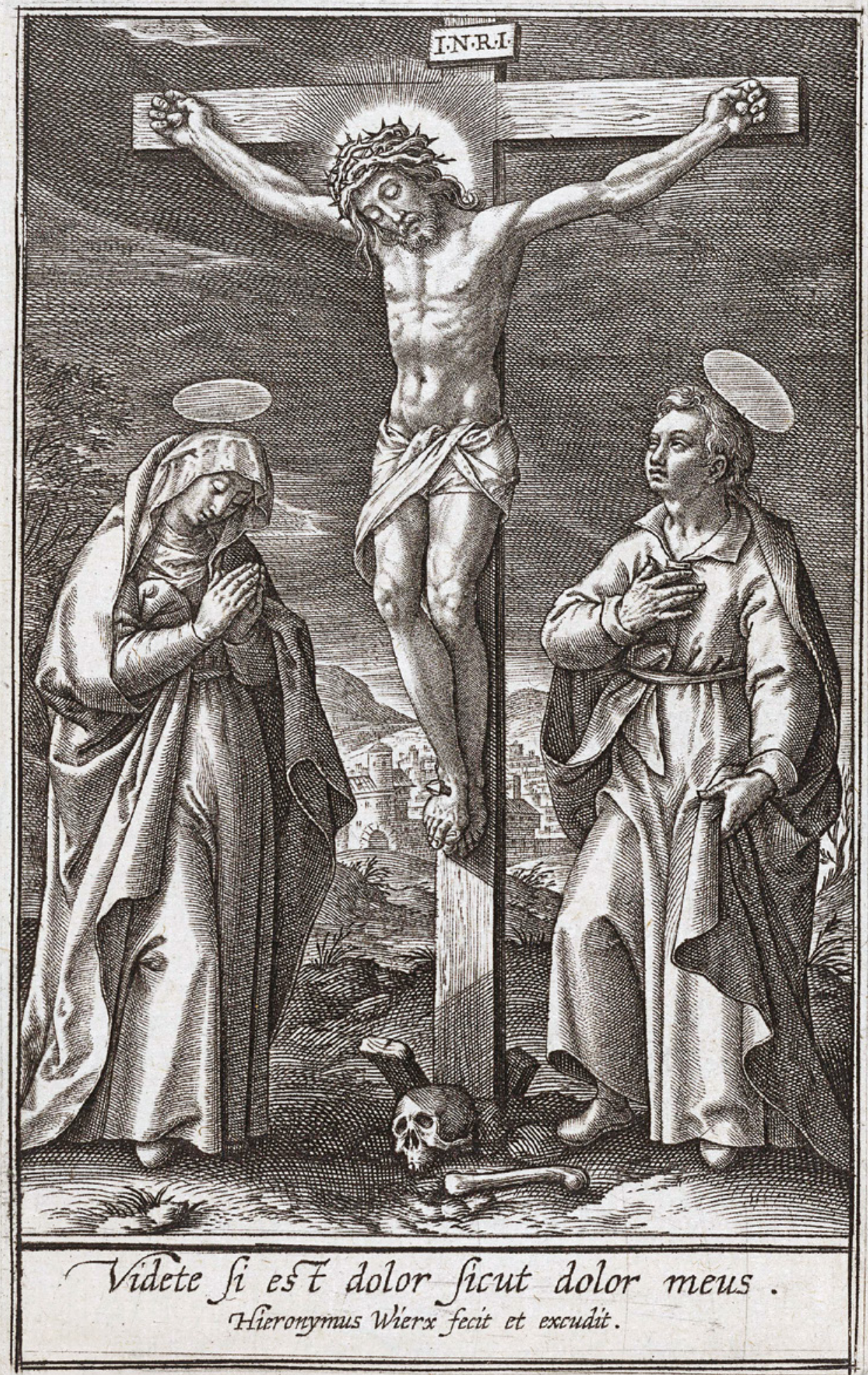


FIGURE 3.17B Projection cast by Shinji Yamamoto, Makyō Mirror, 1989, bronze. Vatican City, Musei Vaticani, Vatican Ethnological Museum

PHото: (C) MIA M. MOCHIZUKI

Hieronymus Wierix, Crucifixion with Our Lady and St.John, before 1619, engraving (inv. no. 1859,0709 ·3082). London, British Museum PHOTO: (C) THE TRUSTEES OF THE BRITISH MUSEUM 


\section{I8. I MAGO PRIMISECVLI SOC. IESV.}

\section{Ignatius è cathedrâ diuini amoris igne concionem inflammat.}

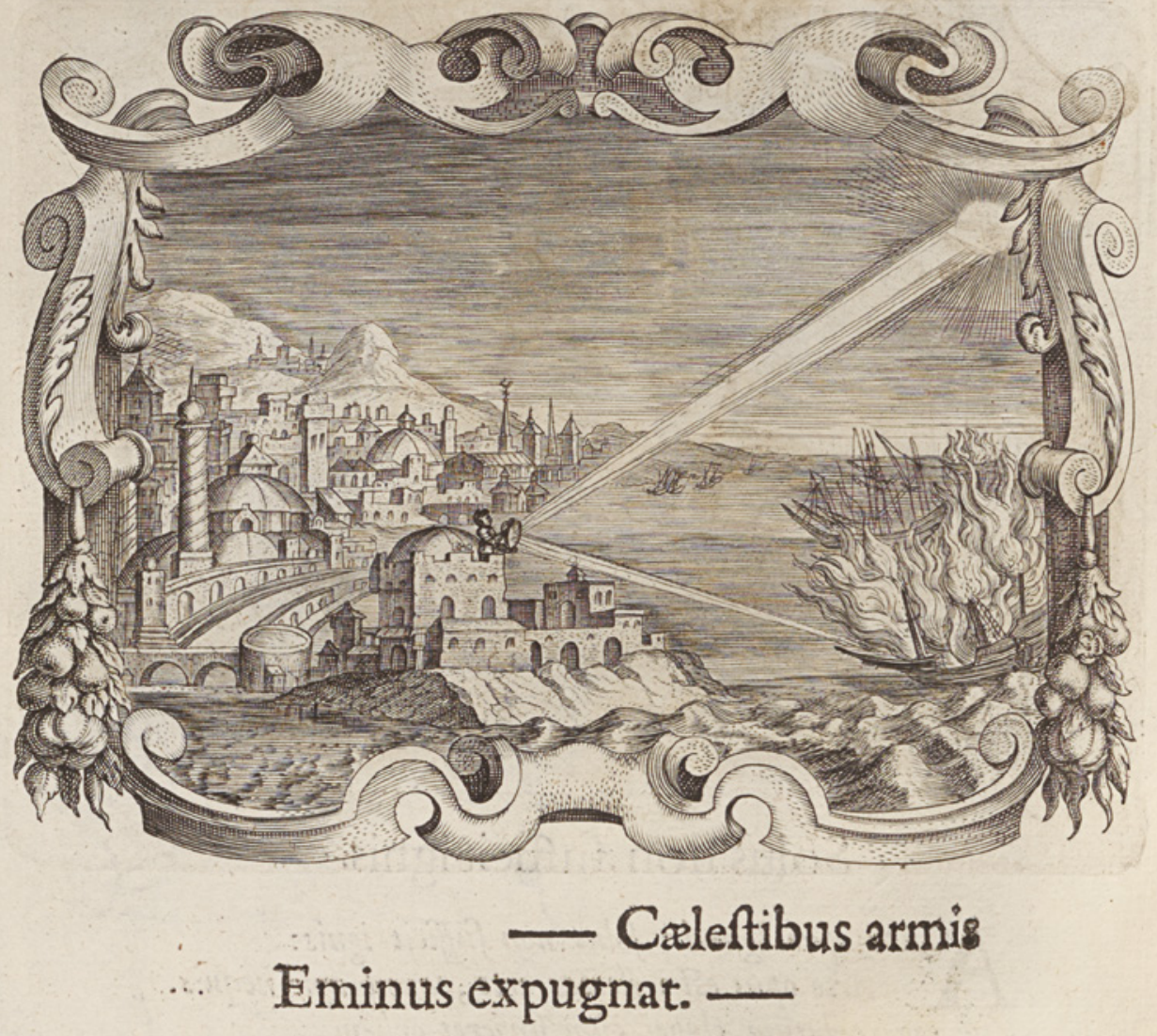

FIGURE 3.18 Andries Pauwels and Cornelis Galle, Ignatius è cathedrâ diuini amoris igne concionem inflammat, in de Bolland and Henskens, eds., Imago primi saeculi Societatis Iesv, 718, engraving (call no. vB 8.556 C). Brussels, Bibliothèque Royale de Belgique, Rare Books PHOTO: (C) BIBLIOTHÈQUE ROYALE DE BELGIQUE

FIGURE 3.19 Japanese Artist, Makyō Mirror, Front and Reverse, eighteenth century, 

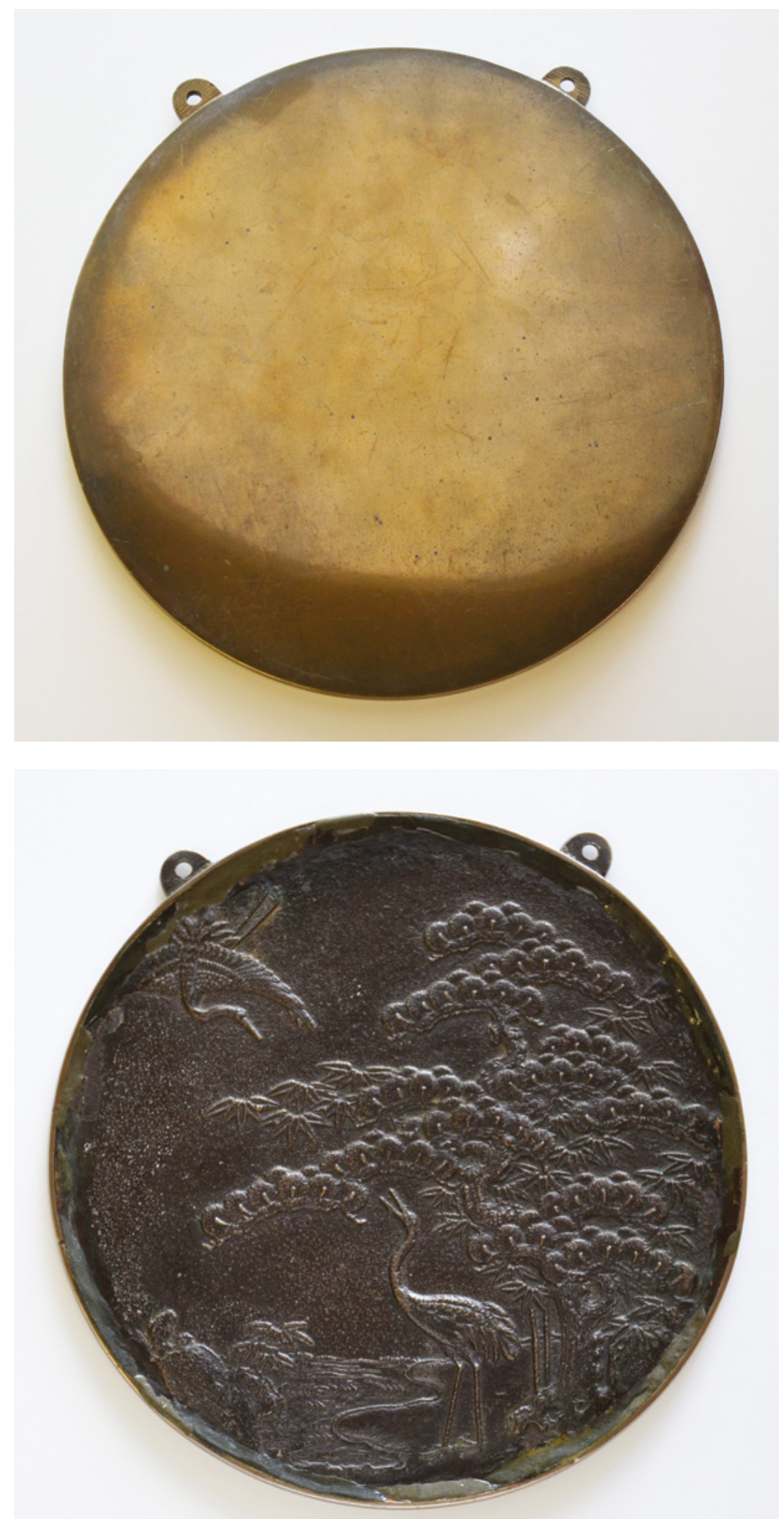

Mia M. Mochizuki - 9789004498228

Downloaded from Brill.come4/26/2023 01:48:39PM 
This hidden facet allowed the makyō to condense the functions of three mirrors in David's Duodecim specula aliquando videre desideranti concinnata (Twelve mirrors arranged for one wishing now at last to see [Antwerp: Plantin Press under Jan Moretus, 1610]): a mirror as a model ("Specvlvm exemplvm."); a false mirror ("Specvlvm fallax."), whose seeming deception actually leads to truth; and most importantly, a "mirror of creatures" ("Specvlvm creatvrarvm."), which linked mimesis to the world. ${ }^{294}$ In the Specvlvm creatvrarvm, a couple kneels before a round mirror, whose cosmic vista of the earth is juxtaposed against a heavenly vision of God, as the first three letters ("A," "B," and " $\mathrm{C}$ ") of the Nadalian key below clarify the contemplation of the invisible through the visible ("Inuisibilium per visibilia / contemplatio.") (fig. 3.20). It was only through the reflection of divine creation, the world via the lens of Genesis, that humankind could see God indirectly, as attested by the surrounding pictorial anecdotes whose glimpses of the celestial occur during mundane daily activities. ${ }^{295}$ Likewise, the makyō mirror employed illusion (illudere) that was both elusive (eludere) and allusive (alludere) to the issues of visibility that continued to plague Reformation objects, paving the way for a contemporary art that Niklas Luhmann (1927-98) has characterized by its reliance on a perceptibility that resides in the boundaries of the invisible, incorporating what it excludes as it draws admiration for this sleight of hand. ${ }^{296}$ The significance

294 Anne-Katrin Sors, Allegorische Andachtsbücher in Antwerpen (Göttingen: Universitätsverlag Göttingen, 2015), 116-38.

295 For example (from left to right, top to bottom): Jacob's ladder bridges heaven and earth (Gn 28:10-22) (D), so Job, standing before the ladder, can pursue a divine path via the created world (F); St. Bernard reflects on God in the woods (E); a man admires the lilies of the field and the birds of the sky (Mt 6:26-28) (H); and a woman studies the "heavenly acre" of the "capable wife's" cornfield (Prv 31:10-31) (G). For more on this image's relationship to the speculative catena on which David structured his Duodecim specula, see Walter S. Melion, "Introduction: Quid est sacramentum?," in Quid est sacramentum? Visual Representation of Sacred Mysteries in Early Modern Europe, 1400-1700, ed. Walter S. Melion, Elizabeth Carson Pastan, and Lee Palmer Wandel, Intersections: Interdisciplinary Studies in Early Modern Culture 65 (Leiden: Brill, 2019), 1-54; Melion, "Meditative Images and the Psychology of the Soul," in Image and Imagination of the Religious Self in Late Medieval and Early Modern Europe, ed. Reindert Falkenburg, Walter S. Melion, and Todd M. Richardson (Turnhout: Brepols, 2008), 1-36.

296 Luhmann, Art as a Social System, 264-68; Mia M. Mochizuki, "The Dutch Text Painting," Word and Image 23 (2007): 72-88; Mochizuki, Netherlandish Image after Iconoclasm; Koen Vermeir, "The Magic of the Magic Lantern (166o-1700): On Analogical Demonstration

FIGURE 3.20 Theodoor Galle, Specvlvm creatvrarvm, in Joannes David, Duodecim specula (Antwerp: Plantin Press under Jan Moretus, 1610), 96, engraving (call no. VB 1.994 1 A RP). Brussels, Bibliothèque Royale de Belgique, Rare Books

PHOTO: (C) BIBLIOTHÈQUE ROYALE DE BELGIQUE 
VIII. SPECVLVM CREATVRARVM.

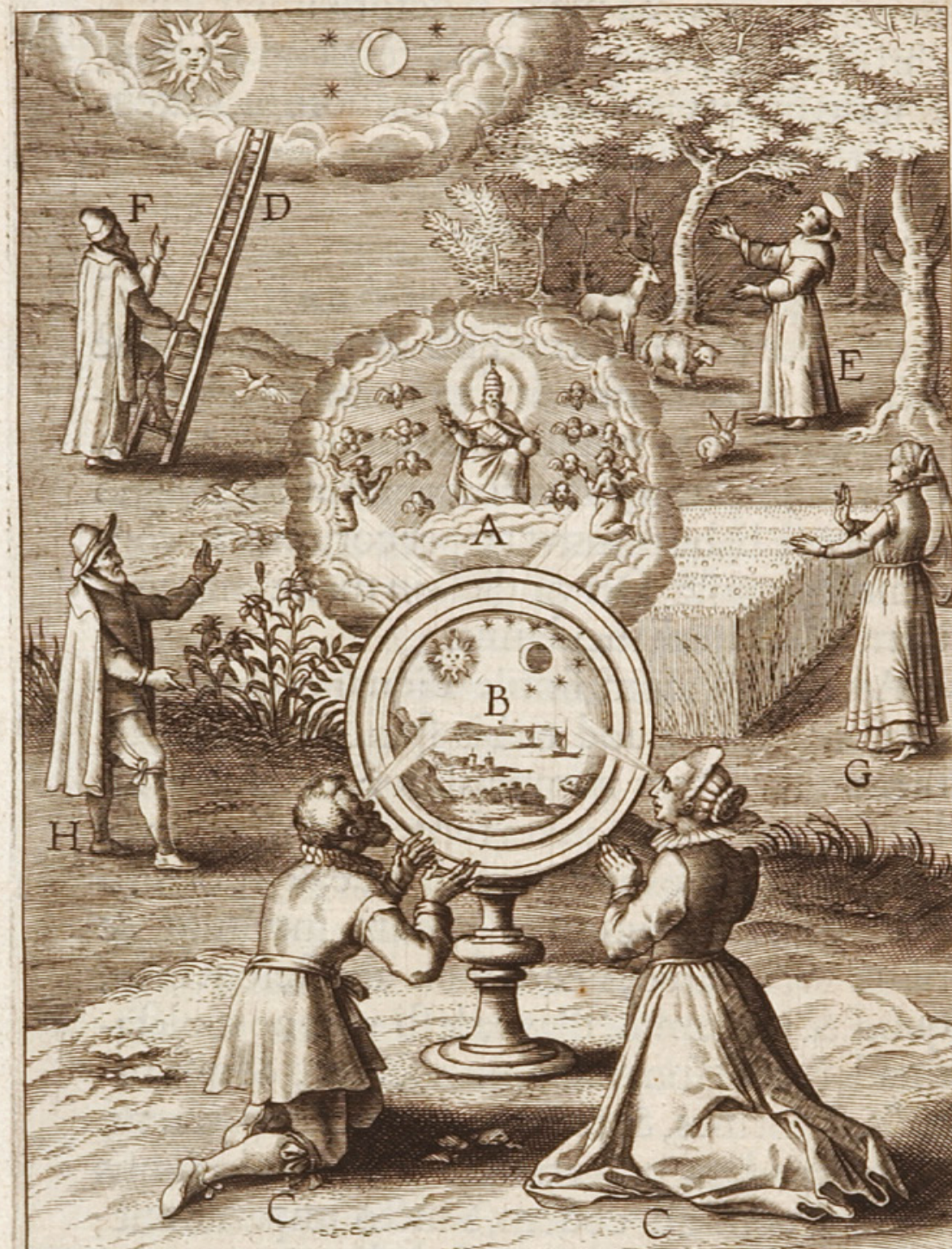

Quot rerum fpecies; SPECVLIS tot, Conditor vnus Cernitur: vtendo gratus vt effe velis .

\begin{tabular}{|c|c|}
\hline $\begin{array}{l}\text { A.B.C. Inuifibitum per vifibitia } \\
\text { D. Scala, ad arcana cali per } \\
\text { E. S. Bernardus inter arbores } \\
\text { diuina contemplans. }\end{array}$ & $\begin{array}{l}\text { F. Iob, quafi per fealam, operum } \\
\text { Dei consideratione quoufque } \\
\text { profecerit. } \\
\text { G. Mulier fortis comfident agrum } \\
\text { calestem, quem comparet. } \\
\text { H. Re/picite litia agri, ot volucres cali. }\end{array}$ \\
\hline
\end{tabular}


of technologies like the mirror for Jesuit picture-making lay in their ability to initiate a Heideggerian notion of "unconcealment" - "Technology is therefore no mere means. Technology is a way of revealing"-and inaugurate a mechanistic view of art that would come to espouse novelty and the incongruous as hallmarks of a modern image. ${ }^{297}$

\subsection{The Subjective Image}

A third contribution should be ascribed to Jesuit art and that was the exploration of the subjective image. Subjectivity in pictures began with contingency, and nowhere was this quality more evident than in the portraiture of saintsin-the-making during canonization campaigns. Antonio Gallonio (1556-16o5), the Oratorian hagiographer and first biographer of St. Filippo Neri (1515-95), pondered how to depict in-process saints in his treatise "How One Should Present Those Who Are Not Canonized" (1596), as Jacopino del Conte (151098) would surely have done for his Portrait of St. Ignatius of Loyola in 1556 (fig. 3.21). ${ }^{298}$ A portrait of St. Ignatius was particularly problematic, since he had famously rejected having his appearance recorded during his lifetime in favor of his behavior in imitatione Christi. ${ }^{299}$ So there was a valid question

and the Visualization of the Invisible," British Journal for the History of Science 38, no. 2 (June 2005): 127-59, here 140, 158.

297 Heidegger, "Frage nach der Technik," 13; Heidegger, "Question concerning Technology," 11-12.

298 "De his quae prestari possunt non canonizatis ad Augustinum Cusanum Cardinalem amplissimi auctore Antonio Gallonio," unpublished ms, Biblioteca Vallicelliana, Rome, MS G. 91, or another copy, MS H. 14, fols. $272^{r}-307^{\text {r }}$; Simon Ditchfield, "Coping with the Beati moderni': Canonization Procedure in the Aftermath of the Council of Trent," in Ite inflammate omnia: Selected Historical Papers from Conferences Held at Loyola and Rome in 2006, ed. Thomas McCoog, S.J. (Rome: Institutum Historicum Societatis Iesu, 2010), 413-39, here 426-27.

299 Despite some claims to the contrary, most portraits of St. Ignatius were not made during his lifetime, with the possible exception of the Portrait of St. Ignatius of Loyola in the Museo Provinciale di Sondrio in Lombardy, Italy, whose later frame testifies that it was a gift from Nicolás de Bobadilla (c.15०9-9o) to Giovanni Maria Guicciardi (1508-96), likely painted after Bobadilla's sketch in Rome in 1543, the year of the donation. The Sondrio Portrait of St. Ignatius of Loyola may no longer have been known to exist by the time of Polanco's writing, since it had been housed in a private collection in Madrid. J. Carlos Coupeau, S.J., "Juan de Polanco's Role as Secretary of Ignatius of Loyola: 'His Memory and Hands," in McCoog, Ite inflammate omnia, 109-27; Heinrich Pfeiffer, s.J., "The Iconography of the Society of Jesus," trans. John C. Traupman, in O'Malley and Bailey, Jesuits and the Arts, 200-28, here 206-8; Wilhelm Schamoni, The Face of the Saints, trans. Anne Fremantle (New York: Pantheon Books, 1947), 134-37; Ursula König-Nordhoff, Ignatius von Loyola: Studien zur Entwicklung einerneuen Heiligen-Ikonographie im Rahmen einer Kanonisationskampagne um 1600 (Berlin: Gebr. Mann Verlag, 1982), 36-37, 67-70, 75 . 


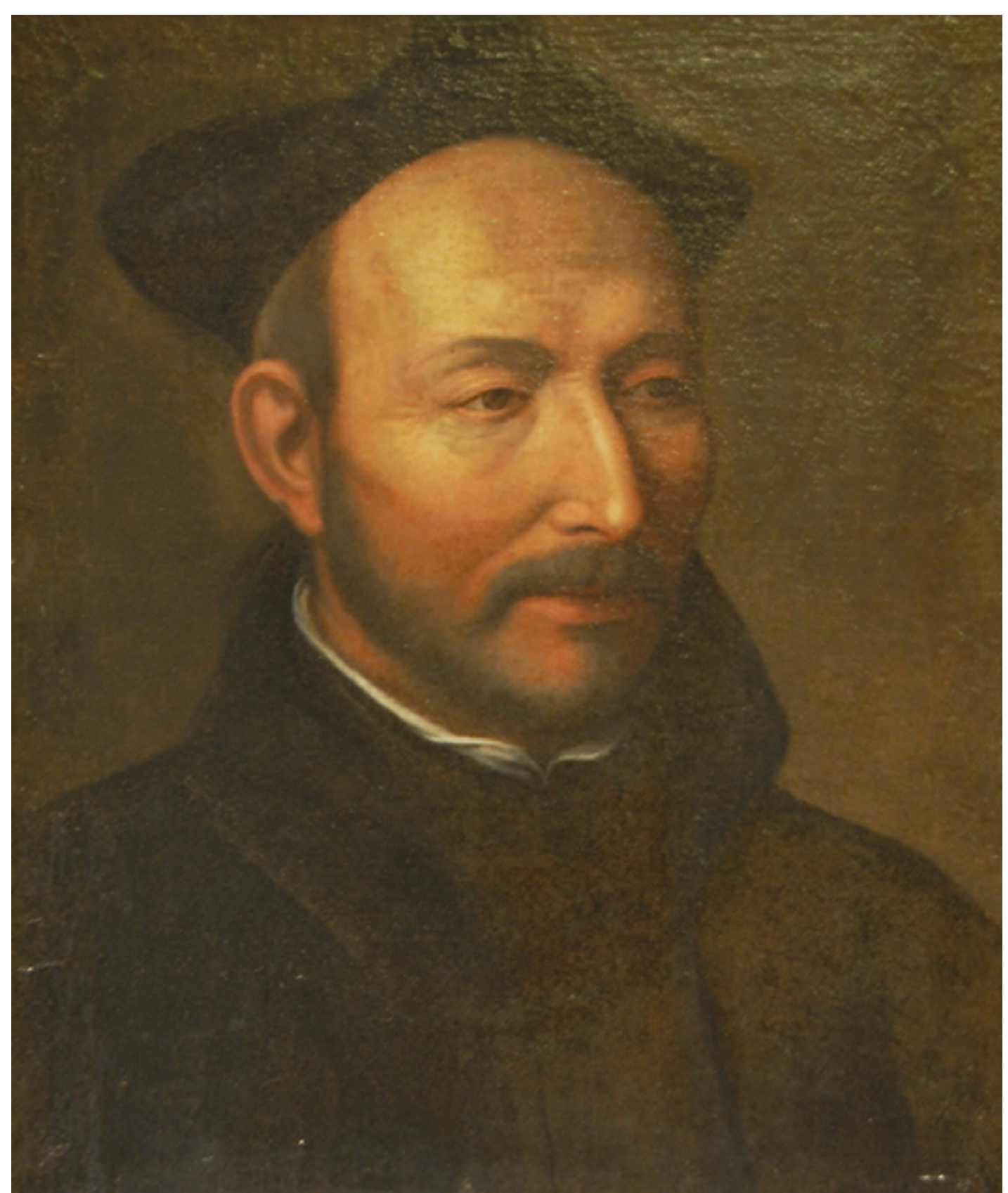

FIGURE 3.21 Jacopino del Conte, Portrait of St. Ignatius of Loyola, 1556, oil on canvas. Rome, Casa Generalizia dei Gesuiti

PHOTO: ( ) ARCHIVUM ROMANUM SOCIETATIS IESU 
whether portraiture was desirable for early Jesuits, and if so, how his likeness could be captured several generations after his death. Ignatius's pragmatic secretary, Polanco, had the foresight to tackle this omission by instructing in a letter (August 6, 1556) that a death mask of St. Ignatius, today housed in the curia of the Society of Jesus in Rome, be made from his body shortly after his passing on July 31,1556 . The death mask of St. Ignatius was then used as the source for del Conte's Portrait of St. Ignatius of Loyola, like much of his early portraiture, and it has long been considered the first "true" painting of St. Ignatius where individualized features were transferred from body to mask to portrait. However, the question remained whether to include a halo. Only saints could be portrayed with the attributes of sanctity, so a nimbus or halo could simply be affixed to the picture post-canonization. Yet some artists seem to have anticipated positive outcomes; as late as October 30, 1626, Pope Urban VIII (1568-1644, r.1623-44) would feel compelled to forbid halos for pictures of those who had not yet been officially beatified or canonized. ${ }^{300}$ Such a decree suggests a canonization date should carry less weight in determining the date of a painting than is often ascribed, and it lends support to the revisionary, and now widely accepted, belief that the need to compile visual evidence of a "cultus publicus" (public cult) prompted more image-making, where saint portraiture largely preceded canonization, rather than vice versa.

300 Although Pope Clement VIII is believed to have tolerated portraits of Xavier with a halo long before beatification, like the miracle-working Portrait of St. Francis Xavier (1603) for the Church of St. Francis Xavier in Kottar on Cape Comorin (Kanyakumari, Tamil Nadu, India), the documentation of his Congregazione de Beati preserves the irritation that could be engendered by local worship of imagery without papal approval, specifically singling out the cults of Carlo Borromeo, Filippo Neri, and Ignatius of Loyola. Ditchfield, "Coping with the Beati moderni,"” 424-28; Miguel Gotor, I beati del Papa: Santità, Inquisizione e obbedienza in età moderna, Biblioteca della "Rivista di storia e letteratura religiosa" 16 (Florence: Leo S. Olschki, 2002), 127-253; Gotor, "La fabbrica dei santi: La riforma urbaniana e il modello tridentino," in Storia d'Italia: Annali 16. Roma, città del papa, ed. Luigi Fiorani and Adriano Prosperi (Turin: Einaudi, 200o), 696-708; König-Nordhoff, Ignatius von Loyola, 3o, 94-96; Maria Cristina Osswald, "Die Entstehung einer Ikonographie des Franz Xaver im Kontext seiner kultischen Verehrung in den Jahren von $155^{2}$ bis 1640," in Franz Xaver: Patron der Missionen; Festschrift zum 45o. Todestag, ed. Rita Haub and Julius Oswald, S.J., Jesuitica 4 (Regensburg: Verlag Schnell \& Steiner, 2002), 6o-8o, here 68; Osswald, "The Iconography and Cult of Francis Xavier, 1552-1640," Archivum historicum Societatis Iesu 71 (July-December 2002): 259-77, here 266; Giovanni Papa, Le cause di canonizzazione nel primo periodo della Congregazione dei Riti (1588-1634), Congregazione delle Cause dei Santi sussidi per lo studio delle cause dei santi 7 (Vatican City: Urbaniana University Press, 2001), 57-63; Georg Schurhammer, s.J., "Die Heiligsprechung Franz Xavers (zum 12. März 1922)," Gesammelte Studien, 4, part 1:467-79, here 467-68, 474-75; Grace A.H. Vlam, "The Portrait of S. Francis Xavier in Kobe," Zeitschrift für Kunstgeschichte 42, no. 1 (1979): 48-6o, here $56-57$. 
Canonization portraits catalyzed the opportunities contingency presented to pictures, releasing objects from the strictures of intentionality. The two highest profile early canonization procedures of the Society of Jesus were those of St. Ignatius of Loyola, the prime initiator of the Society of Jesus, and St. Francis Xavier, the preeminent missionary of the order, who would be canonized together on March 12, 1622 by Pope Gregory XV (1554-1623, r.1621-23) ${ }^{301}$ But they were by no means straightforward. Even before St. Ignatius's formal canonization candidacy had begun, it took three decades, from the start of the reign of Pope Sixtus V (1521-90, r.1585-90) to the death of Pope Clement VIII (1536-1605, r.1592-1605), just to open proceedings. ${ }^{302}$ Representatives of empire-aspiring nations then placed their fingers on the scales at critical junctures; members of other religious orders sought the canonization of their founders, like St. Filippo Neri of the Oratorians (approved) and Cardinal Gian Pietro Carafa (Pope Paul IV, 1476-1559, r.1555-59) of the Theatines (rejected); and brother Jesuits debated how broadly the duties of the superior general should be construed. The Roman Catholic Church itself was just emerging from what Peter Burke has deemed a "crisis of canonization," a sixty-five-year hiatus in canonizations (1523-88) that had only resumed with the formation of the Sacred Congregation of Rites and Ceremonies by Pope Sixtus v (January 22, 1588). ${ }^{303}$ With a thorough grounding in the kairos moment of personal choice from the Spiritual Exercises, Jesuits were well positioned to confront the lengthy periods of uncertainty that were ingrained in the process of portraying new

301 Pope Paul v beatified St. Ignatius of Loyola on July 27, 1609 and St. Francis Xavier on October 25, 1619; they were canonized together, along with St. Teresa of Ávila (or St. Teresa of Jesus, 1515-82), St. Filippo Neri, and St. Isidore the Farmer (c.1070-1130), on March 12, 1622 by Pope Gregory Xv, although the decision was only published the following year by Pope Urban vin (August 6, 1623). Pope Urban viII, Pont. Max. Bulla canonizationis Beati Francisci Xaverii celebratae per Gregorium XV (August 6, 1623), in Monumenta Xaveriana ex autographis vel ex antiquioribus exemplis collecta (Madrid: Typis Augustinus Avrial and Gabrielis Lopez del Horno, 1899-1912), 2:713.

302 König-Nordhoff, Ignatius von Loyola, 34-36. Anthony D. Wright, "La Sua Santità non inclina niente: The Papacy and the Canonization of Ignatius of Loyola," in McCoog, Ite inflammate omnia, $440-55$.

303 The next thirty-four years $(1588-1622)$ would see no fewer than ten canonizations and fifteen beatifications, and the pace picked up from only six formal canonizations in the sixteenth century to twenty-four in the seventeenth century, and twenty-nine in the eighteenth century. Fifty-five saints were approved for canonization from 1588 to 1767 . Peter Burke, "How To Be a Counter-Reformation Saint," in Religion and Society in Early Modern Europe 1500-1800, ed. Kaspar von Greyerz (London: German Historical Institute and George Allen \& Unwin, 1984), here 46-48; Ditchfield, "'Coping with the Beati moderni," 416-19; Simon Ditchfield, "Tridentine Worship and the Cult of Saints," in The Cambridge History of Christianity: Vol. 6; Reform and Expansion 1500-1660, ed. Ronnie Po-chia Hsia (Cambridge: Cambridge University Press, 2007), 201-24, here 202; Gotor, "Fabbrica dei santi," 679-727. 
(modern) saints, or "beati moderni." ${ }^{304}$ After the complications of conveying authenticity in networked images, and the limits of mimesis foregrounded in the technologically produced object, the subjective picture finally acknowledged the role of "chance images" in a society marked by the seismic shifts of Reformation and sustained overseas global encounter that would become a laboratory for many of the issues that would come to define modernity.

The ultimate contingency in Christianity was the crucifixion, and in a counterfactual exercise, the historian of early modern religion Carlos Eire has opined that there would have been no Christianity without the crucifixion, an idea expressed by the Apostle Paul as "no cross, no salvation," and by Karl Rahner as "the cross of the Lord is and remains the fork in the world of human history" ${ }^{305}$ Post-Tridentine scholars recognized that a miasma of indecision hung over the cross: all the Gospel accounts suggested that Jesus could have been set free, and Pontius Pilate himself wanted to do so, if the crowds had not bayed for blood. The philosophy of probabilism, which Jesuits like Francisco de Toledo (1532-96), Gregorio de Valencia (c.1549-16o3), Francisco Suárez (1548-1617), and Gabriel Vázquez (c.1549-1604) helped frame, furnished a theology of contingency that could lay accusations of moral sophistry to rest by mining the aporiae of the cross. ${ }^{306}$ It was this conditional aspect of crucifixion that would be cultivated in images during an age of anxiety, like an anonymous

304 The name "beati moderni" was chosen by Pope Clement VIII to connect post-Reformation saints to their predecessors, while highlighting the decisively papal and universal turn away from canonizations based on long-established ("ab immemorabile tempore") regional cult practice. Ditchfield, "Coping with the Beati moderni," 429; Simon Ditchfield, "How Not to Be a Counter-Reformation Saint: The Attempted Canonization of Pope Gregory X, 1622-45," Papers of the British School of Rome 6o (1992): 379-422, here 395; Ditchfield, "Thinking with Saints: Sanctity and Society in the Early Modern World," Critical Inquiry 35, no. 3 (Spring 2009): 552-84, here 577 .

305 Carlos M.N. Eire, "Pontius Pilate Spares Jesus: Christianity without the Crucifixion," in The Collected What If? Eminent Historians Imagining What Might Have Been, ed. Robert Cowley (New York: G.P. Putnam's Sons, 2001), 448-67, esp. 450-52; Eire, "The Quest for a Counterfactual Jesus: Imagining the West without the Cross," in Unmaking the West: "What-If?" Scenarios That Rewrite World History, ed. Philip E. Tetlock, Richard Ned Lebow, and Geoffrey Parker (Ann Arbor: University of Michigan Press, 2006), 119-42, esp. 119-23, 131-33; K. Rahner, Spiritual Exercises, 234, 236-37.

306 Stefania Tutino, Shadows of Doubt: Language and Truth in Post-Reformation Catholic Culture (Oxford: Oxford University Press, 2014); Tutino, Uncertainty in Post-Reformation Catholicism: A History of Probabilism (Oxford: Oxford University Press, 2018), 52-88. 


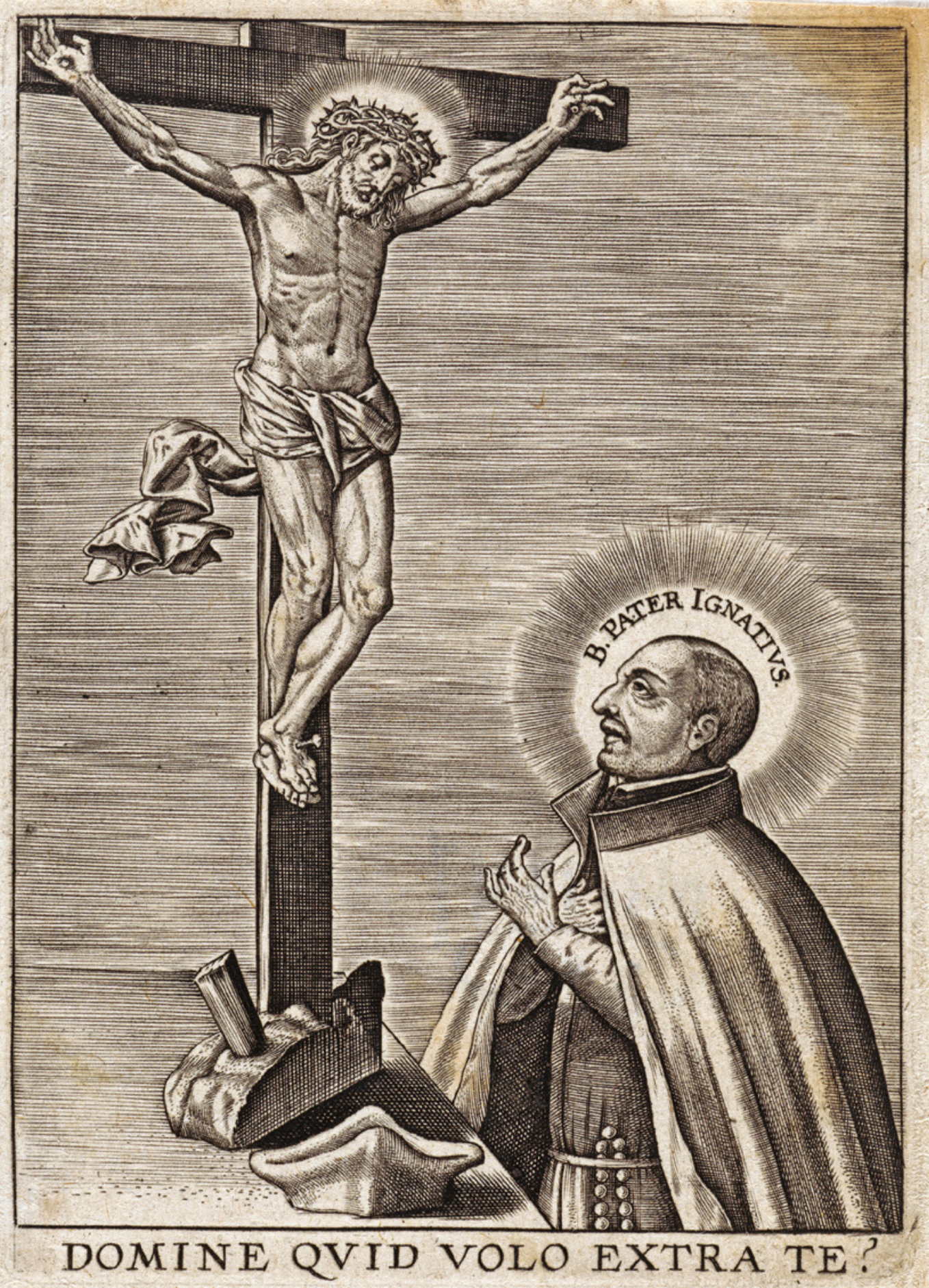


copy made after a Hieronymus Wierix print (fecit), from a de Vos design (invenit), of a Portrait of St. Ignatius with a Crucifix (fig. 3.22). ${ }^{307}$ The staging of St. Ignatius before a raised crucifix evokes verse 53 of the Spiritual Exercises, the culmination of the first week, when the exercitant visualized Christ on the cross as dialogue partner:

Colloquy. Imagine Christ our Lord suspended on the cross before you, and converse with him in a colloquy: How is it that he, although he is the Creator, has come to make himself into a human being? How is that he has passed from eternal life to death here in time, and to die in this way for my sins?

In a similar way, reflect on yourself and ask: What have I done for Christ? What am I doing for Christ? What ought I to do for Christ?

In this way, too, gazing on him in so pitiful a state as he hangs on the cross, speak out whatever comes to your mind. ${ }^{308}$

The skull, usually seen at the foot of the cross as a reference to where Adam lay buried and from whence God will come to redeem humankind, was replaced by the biretta of Jesuit commitment to a reformed world above the rhetorical question: "Lord, what could I desire beyond you?" ("Domine qvid volo extra $t e ? ") .{ }^{309}$ Likewise, Nadal would state: "The [Roman Catholic] Church receives its meaning from the cross of Christ. So also the Society," and more emphatically, "It comes to this: the living of our vocation is in the carrying of the cross. If we fail here, we are quitting the road that leads to the purpose of our vocation."310 Crucifixion played a decisive role throughout the Spiritual Exercises, and Hugo Rahner has condensed the objective of the Exercises into the remodeling of the self on the "crucified Christ." 311 The cross was the tie between the Spiritual Exercises and the systemization of chance in a narrative that revolved around

307 Mauquoy-Hendrickx, Estampes des Wierix, 3, part 1:371, pl. 271, fig. 1843.

308 Fleming, Draw Me into Your Friendship, 48-49; Ganss, Spiritual Exercises of Saint Ignatius, 42; H. Rahner, Ignatius the Theologian, 59.

309 Hugo Rahner, s.J., Greek Myths and Christian Mystery, trans. Brian Battershaw (New York: Biblio \& Tannen Booksellers and Publishers, 1971 [1963]), 61-64.

310 Bangert, Jerome Nadal, 218; Miguel Nicolau, S.J., Pláticas espirituales del P.Jeronimo Nadal, S.I. en Coimbra, ${ }_{1561}$ (Granada: Facultad Teológica de la Compañía de Jesús, 1945), 109; Jerónimo Nadal, P. Hieronymi Nadal orationis obeservationes, ed. Michael [Miguel] Nicolau, S.J. (Rome: Institutum Historicum Societatis Iesu, 1964), 171.

311 H. Rahner, Ignatius the Theologian, 130-33. 
decisions, the exercitant's Election and Christ's resolve to bear the weight of the cross despite the repercussions of disgrace and death. ${ }^{312}$

While the importance of the crucifixion for Jesuits has been recognized, what has yet to be considered is how Ignatius turned the cross into a hermeneutic tool of interactive technology for the visible, thereby crafting what might be termed a "crucifixion economy" for picture-making. It was no accident that the second image hung on the printing press of the Imago's printer-priest was a Crucifixion; the picture was set frontally to catch the viewer's eye, the present into future to the Madonna's past tense (fig. 3.11). Chance opened a mystical space in painting, the place where through the mobilizing of the accidental, the past was "inspirited" with the power of the possible and something more profound was achieved than initially could have been envisioned. The efficacy of the arbitrary lay in its capacity for change, akin to how Aristotle understood the nous as raw aptitude in passage to actuality, that "has no other nature than that of being potential, and before thinking, it is absolutely nothing."313 One of Bolswert's images for Sucquet's Via vitae aeternae - Inspice, \& imitare virtutis N. exemplar, quod tibi à Domino monstratum est (Look and imitate the example of virtue that has been displayed for you by Our Lord) - explicitly extended the logic of crucifixion to the creation of imagery in his adaption of Nadal's pictorial formula (fig. 3.23). ${ }^{314}$ Christ carrying the cross provides the model for the angel-assisted painter in the foreground as Jesus invites others to follow him up the hill ("Venite post me.") to the crucified Christ at the peak; there, the imperative "Look and make a second example [after this]" ("Inspice et fac secun / dum exemplar.") echoes Ignatius's call for portraiture through the imitation of the conduct of Christ.

The crucifixion bestowed an alternate pictorial economy built on the promise of rupture, analogous to de Certeau's emphasis on the generative purpose of the interstitial break in the Spiritual Exercises that would play out in Nadal's Evangelicae. $^{315}$ Georges Didi-Huberman has advocated understanding the

312 St. Ignatius of Loyola, Exercitia spiritualia Sancti Ignatii de Loyola et eorumque directoria, 2:525; H. Rahner, Ignatius the Theologian, 55, 101, 131.

313 Aristotle, On the Soul, Parva naturalia, and On Breath, trans. W.S. Hett, Loeb Classical Library 288, rev. ed. (Cambridge, MA: Harvard University Press, 1957), 164-65, sec. 429a, lines $21-22$.

314 Antoine Sucquet, Via vitae aeternae (vol. 1: Antwerp: Martin Nuyts, 1620, vol. 2: Antwerp: Hendrick Aertssens, 1625), 1:452-59; Steffen Zierholz, "Conformitas crucis Christi: Zum Motiv der Kreuzesnachfolge in der jesuitischen Druckgrafik des 17. Jahrhunderts im Licht der Vision von La Storta," Archivum historicum Societatis Iesu 86 (2017): 49-97; Zierholz, Räume der Reform, 119-32, esp. 129-32.

315 De Certeau, "Espace du désir ou le 'fondement' des Exercices spirituels," 122-24; de Certeau, "Space of Desire," 94-95. 


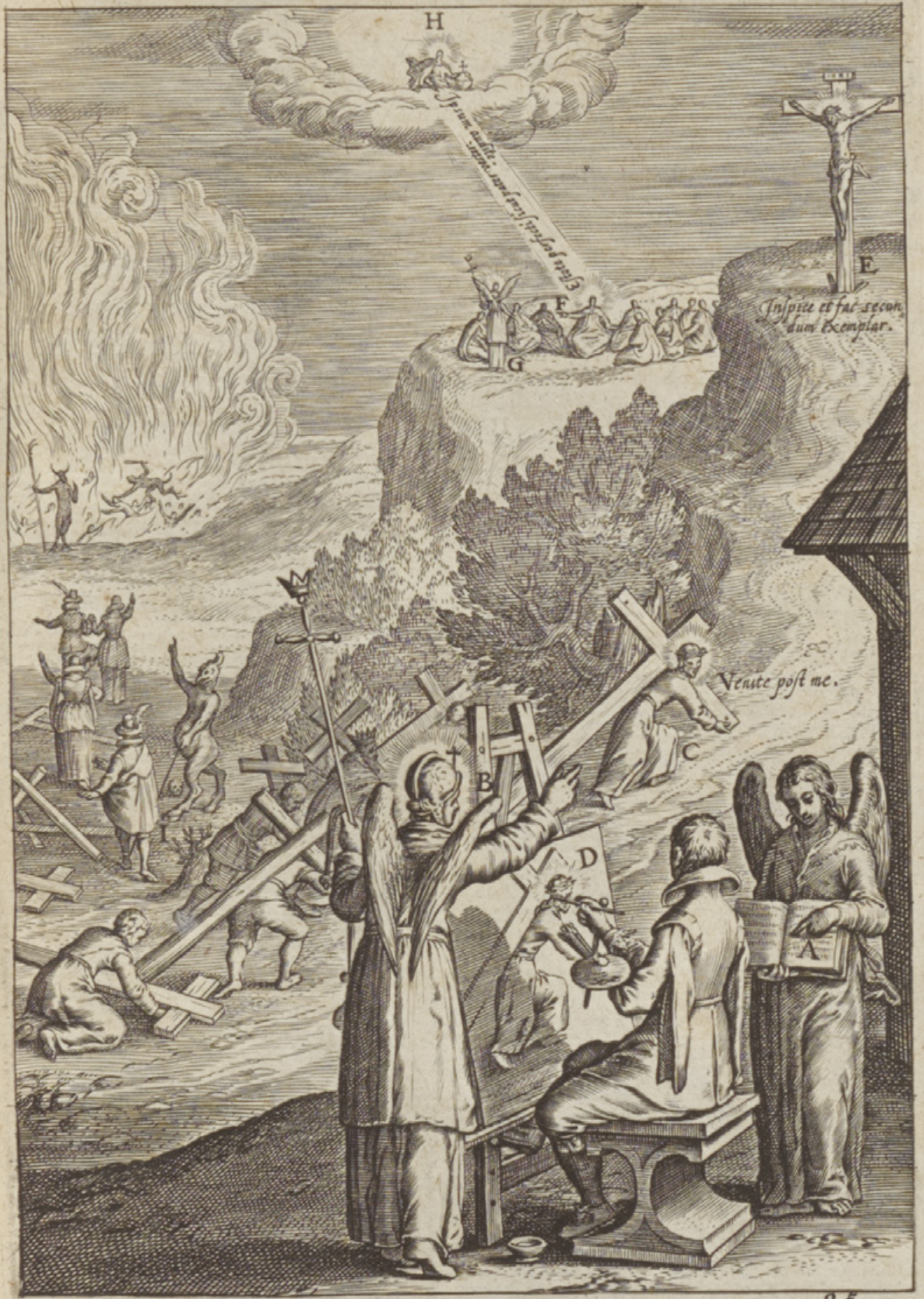

25 
image as rend — the "déchirure," incision, or displacement to offset the detail's certainty-as a break with the logos-centered, iconological methodology of the image as text. ${ }^{316}$ Meditation facilitated access to crucifixion, with the benefit of re-enacting schism in the viewer's time and space, as described by Simone Weil (1909-43): "The function of meditation in itself implies a tearing asunder [...] we cannot conceive of the descent of God towards men or the ascent of men towards God without a tearing asunder." ${ }^{317}$ The portrait had become an assemblage of appearing and disappearing acts, an "eclipse" or transience, a disquiet. ${ }^{318}$ The upshot was that modern western painting, heavily influenced by Christian views of the human figure, only began when humankind no longer experienced him- or herself as a stable, unchanging entity, but rather as a consequence of fateful decisions, be it the fall of man or the no less resonant failures of daily life.

For Jesuits, conformity with the cross entailed a celebration of the world as the key to understanding the self, as seen in the Spiritual Exercises, so images of the "Apostle of the Indies" from outside Europe, like the early seventeenthcentury Portrait of St. Francis Xavier, now in the Kobe City Museum, enhance an understanding of how subjectivity was structured pictorially in three important respects (fig. 3.24). ${ }^{319}$ In this painting, St. Francis Xavier is presented in a

316 Georges Didi-Huberman, Confronting Images: Questioning the Ends of a Certain History of Art, trans. John Goodman (University Park, PA: Pennsylvania State University Press, 2005), 138-228.

317 Simone Weil, Gravity and Grace, trans. Emma Crawford and Mario von der Ruhr (London: Routledge, 2002), 90.

318 Jean-Luc Nancy, Portrait, trans. Sarah Clift and Simon Sparks (New York: Fordham University Press, 2018), 89-92.

319 K. Rahner, "Ignatian Mysticism of Joy in the World," 288, 293. The Kobe Portrait of St. Francis Xavier has been attributed to a Jesuit-trained artist familiar with the Japanese Kanō School of artists, like the Niccolò School's Mancio João Thadeu (1568-1627), who was admitted to the Society in 1606. Vlam, "Portrait of S. Francis Xavier in Kobe," $58-59$. The painting was originally framed in the Japanese hanging scroll (kakemono) style. For conservation analysis, see Nobuyuki Kamba, "Kokuritsu rekishi minzoku hakubutsukan tokutei kenkyū nanban kankei shiryōhan niyoru kōbe shiritsu hakubutsukanzō 'Sei furansisko sabieruzō' no chōsa nikansuru gaiyō," Kōbe shiritsu hakubutsukan kenkyū kiyō

$\leftarrow \quad$ FIGURE 3.23 Boetius Bolswert, Inspice, \& imitare virtutis N. exemplar, quod tibi à Domino monstratum est, in Antoine Sucquet, Via vitae aeternae (vol. 1: Antwerp: Martin III Nuyts, 1620, vol. 2: Antwerp: Hendrick Aertssens, 1625), 1:after 452, engraving (call no. VB 1.999 A RP). Brussels, Bibliothèque Royale de Belgique, Rare Books PHOTO: () BIBLIOTHÈQUE ROYALE DE BELGIQUE 


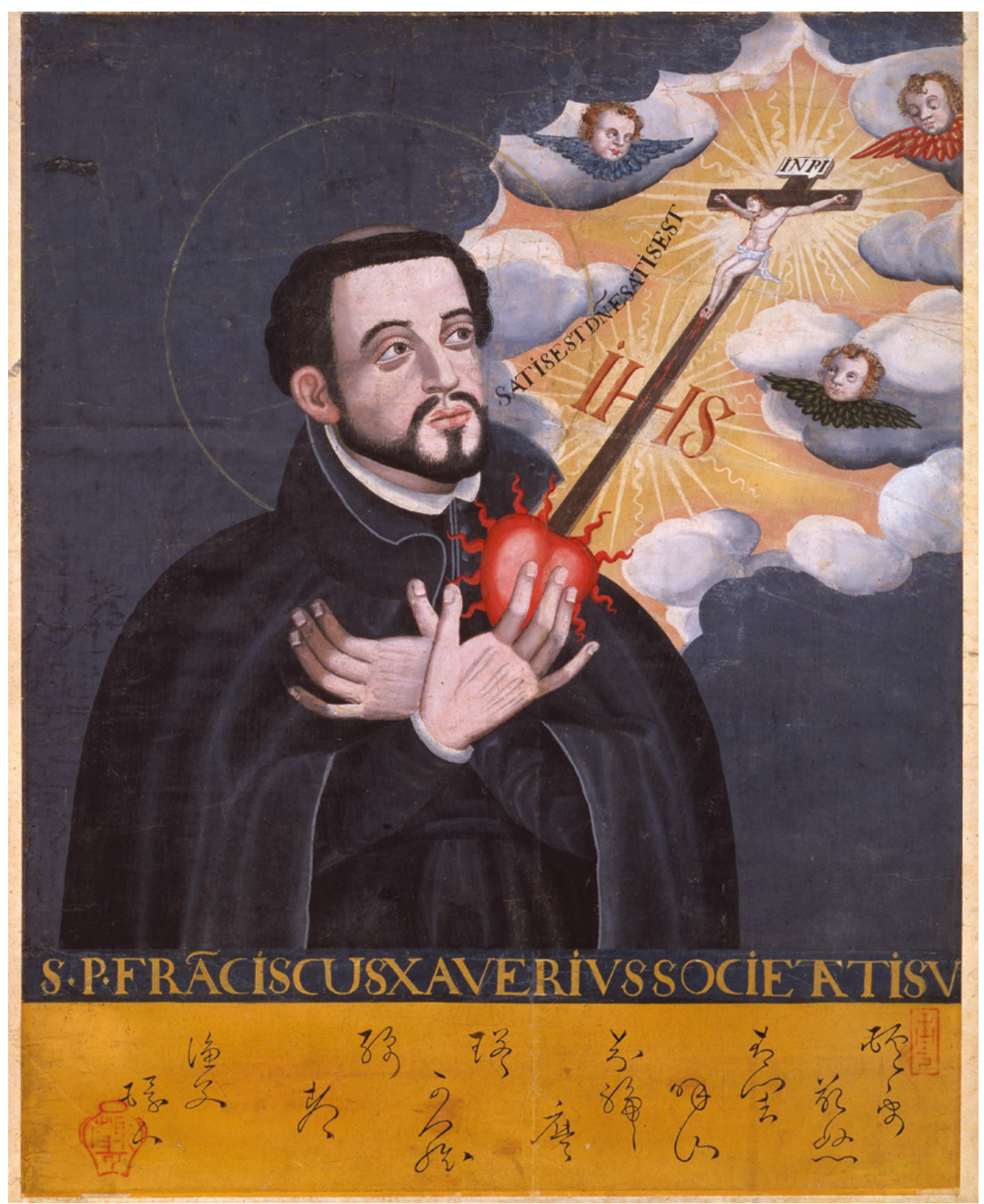

FIGURE 3.24 Niccolò School, Portrait of St. Francis Xavier, early seventeenth century, Japanese colors and ink on paper. Kobe, Kobe City Museum

PHOTO: (C) KOBE CITY MUSEUM 
bust-length portrait, head ringed with a halo and hands crossed at his heart, as a crucifix with an enflamed heart breaks through the clouds, bisecting an "IHS" monogram, below the words "Satis est Domine satis est." (It is enough, Lord, it is enough). First, an often unrecognized aspect of Xavier's contingent canonization process was that it was one of the earliest to arise from extra-European devotion: the feudal lord (daimyō) of Bungo province in eastern Kyushu (part of modern-day Ōita Prefecture), Ōtomo Sōrin (or Ōtomo Yoshishige, 1530-87), had been baptized in 1578 with the baptismal name of Francisco in honor of Xavier, whom he had known as a child. ${ }^{320} \mathrm{He}$ sent a letter requesting Xavier's beatification to Pope Gregory XIII (1502-85, r.1572-85), which was carried by the four young envoys of the first Japanese delegation to Europe, the Tenshō embassy (1582-9o). To support the request, Valignano, who served as the group's initial chaperone, commissioned an "authentic portrait," or vera effigie, of Xavier from his remains in Goa. ${ }^{321}$ In turn, two versions of Xavier's vera effigie were painted, one of which was sent to Rome while the other remained in Goa, maintaining a pictorial hub outside of Europe. ${ }^{322}$ They would become the ground zero for the earliest depictions of Xavier around the world, showing

16 (2000): 1-15, here 8; Akira Tsukahara, "Kōbe shiritsu hakubutsukan shozō 'Sei furanshisuko zabieruzō' no hozon jyōtai to hyōgen kaishaku," Kōbe shiritsu hakubutsukan kenkyū kiyō 35 (March 31, 2019): 3-19, here 6-10.

320 Georg Schurhammer, S.J., "Ein fürstlicher Gönner des hl. Franz Xaver: Ōtomo Yoshishige, König von Bungo," Gesammelte Studien, 4, part 1:327-34; Schurhammer, "Die Heiligsprechung Franz Xavers (zum 12. März 1922)," 467, 474; Schurhammer, "Xavieriusforschung im 16. Jahrhundert zum 30o. Gedenktag der Heiligsprechung (1622-1922) des Hl. Franziskus Xavierius," Gesammelte Studien, 3:57-114, here 82, 105-6; Vlam, "Portrait of S. Francis Xavier in Kobe," 53.

321 The extra-European location of most of Xavier's corporeal relics- the remains of his body had been transported to Goa in 1554, where they would be kept in the Basilica of Bom Jesus, and his right upper arm divided between the Jesuit College of St. Paul in Macau and the Jesuit College of Madre de Deus in Kochi (Kerala, India) in 1619, with only his right forearm sent to the Gesù in Rome in 1614-also shows an appreciation of the global contribution to Xavier's candidacy for sainthood, since Superior General Acquaviva noted in a letter to the provincial of Goa in 1607 that some would have liked the head of Xavier to have been sent to Rome. Osswald, "Entstehung einer Ikonographie des Franz Xaver," 65-67; Osswald, "Iconography and Cult of Francis Xavier, 1552-1640," 263-65; Schamoni, Face of the Saints, 130; Georg Schurhammer, S.J., "Das Bild des Hl. Franz Xaver," Gesammelte Studien, 4, part 1:209-11; Schurhammer, "Das wahre Bild des Hl. Franz Xaver? (zum 3. Dezember)," Gesammelte Studien, 4, part 1:213-15, pl. 5-10.

322 A drawing was made by Manuel Godinho de Erédia (1563-1623), in Goa, $c .1613$, after the lost 1583 Goan vera effigie. Fernando García Gutiérrez, s.J. has suggested a Portrait of St. Francis Xavier in the Cathedral of Tuy, Spain, may be the lost vera effigie sent to Rome, as it formed part of a group of paintings from that city donated to the cathedral on March 5 , 1618. Fernando García Gutiérrez, s.J., "Iconografía de San Francisco Javier en Oriente," Archivum historicum Societatis Iesu 71 (July-December 2002): 279-301, here 282-83, fig. 11; Schurhammer, "Wahre Bild des Hl. Franz Xaver?," 213-15, pl. 5-10. 
how limited conventional center-periphery paradigms can be for this material. The universal arena of a pictorial crucifixion economy ensured the early modern Catholic self was no longer cast as simply a postlapsarian sinner; in the expansion of post-Tridentine religious portraiture to the global stage, the represented person could acquire the agency of subjecthood through the role of chance in artistic production. ${ }^{323}$

Second, the construction of the Kobe Portrait of St. Francis Xavier reveals how partisanship could be subtly intimated in pictures. It is known that at least one copy of the Italian Jesuit Orazio Torsellino's (or Horatius Torsellinus, 154599) De vita Francisci Xaverii (On the life of Francis Xavier [Rome: Luigi Zanetti, 1596]) was in Japan, if not which edition. ${ }^{324}$ However, the printed Frontispiece Portrait of St. Francis Xavier by Theodoor Galle for the first illustrated edition of Torsellino's Vita, with hands grasping the cloth of his tunic on his chest, familiar to many as the first mass-produced image of Xavier and the oldest preserved version of his portrait, was not the source for the Kobe painting (fig. 3.25). Its main model was probably a single-leaf Portrait of St. Francis Xavier with Hands Crossed by Hieronymus Wierix: it shares the same "butterfly" gesture of hands crossed at the wrists and "Satis est" inscription issuing from his mouth (fig. 3.26). ${ }^{325}$ This version derived from the Frontispiece Portrait of St. Francis Xavier for the second edition of Torsellino's Devita Francisci Xaverii (Antwerp:Joachim Trogney, 1596), also by Wierix, that featured the saint in a central oval with four smaller scenes from Xavier's life in the corners. Its attributes referenced a demonstration of Xavier's "heroic virtue" in the garden of the Jesuit College of St. Paul in Goa in 1552, which also explains the insertion of the impassioned heart in the Kobe picture. In a much-repeated anecdote, Xavier's heart burned so intensely while praying that he had to open his cassock, uttering the famous line, "It is enough, Lord, it is enough," as if in Ignatian-inspired rebuttal to the story of Doubting Thomas, who needed to touch Christ's wounds to believe. ${ }^{326}$ Hans-Georg Gadamer's (1900-2002) "occasionality" thesis sheds light on the portraiture of new saints, where content and interpretation were determined "by the occasion for which they are intended, so that they contain more than

323 Sluhovsky, Becoming a New Self, 141; Sluhovsky, "Loyola's Spiritual Exercises and the Modern Self," 228.

324 Tei Nishimura, Namban-bijutsu (Tokyo:Kodansha, 1958), 95-99; Schurhammer, "Xavieriusforschung im 16. Jahrhundert," 87-88, 109-10; Vlam, "Portrait of S. Francis Xavier in Kobe," 54.

325 Mauquoy-Hendrickx, Estampes des Wierix, 3, part 1:362-63, pl. 26o, figs. 18o9-10; Vlam, "Portrait of S. Francis Xavier in Kobe," 54.

326 Georg Schurhammer, s.J., Francis Xavier: His Life, His Times, trans. M. Joseph Costelloe, S.J. (Rome: Institutum Historicum Societatis Iesu, 1973-82), 4:502-4, n. 16; Tsukahara, "Kōbe shiritsu hakubutsukan shozō 'Sei furanshisuko zabieruzō,", 12-14. 


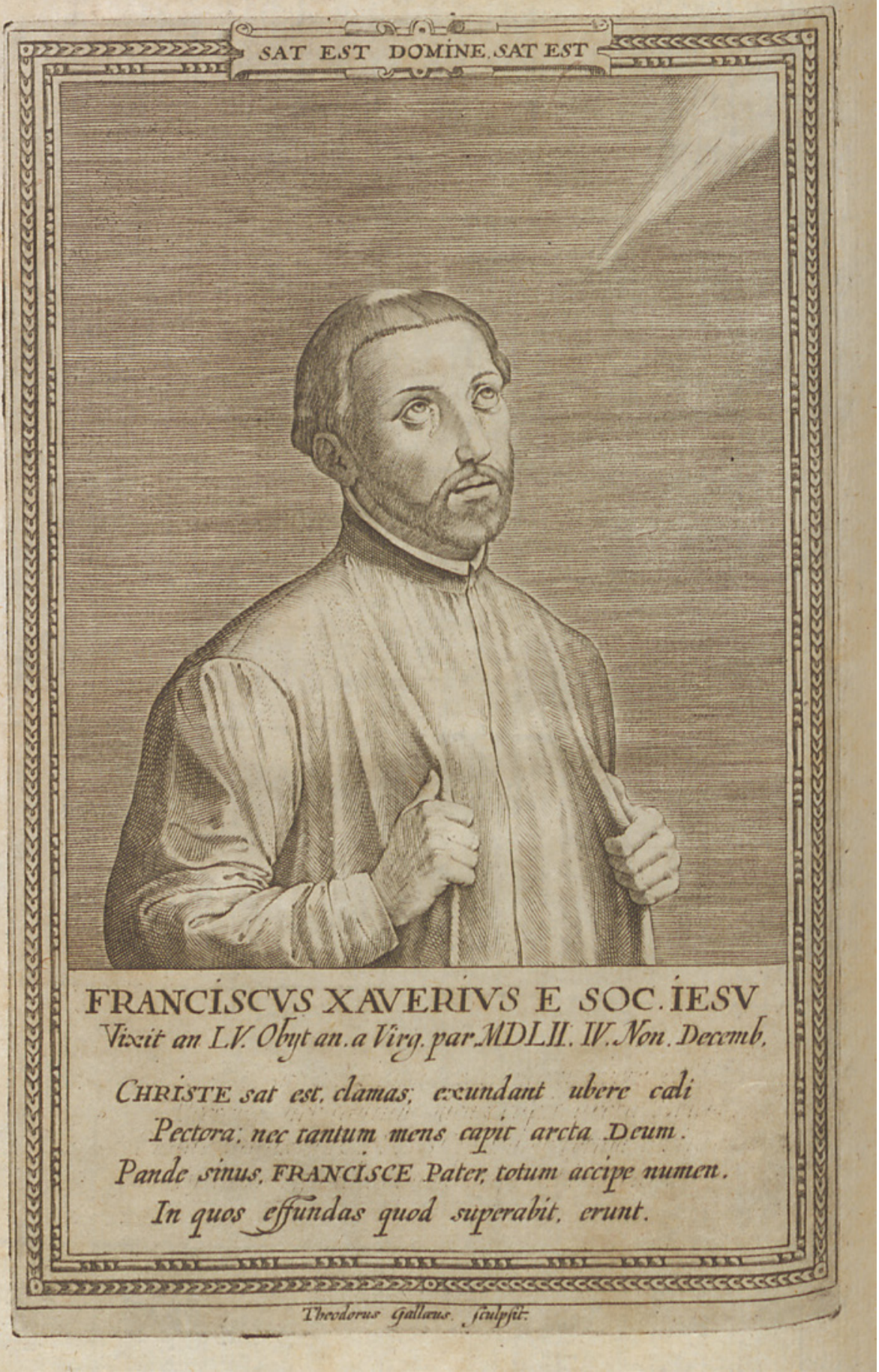

FIGURE 3.25 Theodoor Galle, Frontispiece Portrait of St. Francis Xavier, in Orazio Tursellino, De vita Francisci Xaverii (Rome: Luigi Zanetti, 1596), engraving (call no. *e: 40/244, no. 1). Mainz, Bibliotheken der Stadt Mainz, Wissenschaftliche Stadtbibliothek PHOTO: (C) LANDESHAUPTSTADT MAINZ, AMT FÜR KULTUR UND BIBLIOTHEKEN-WISSENSCHAFTLICHE STADTBIBLIOTHEK 


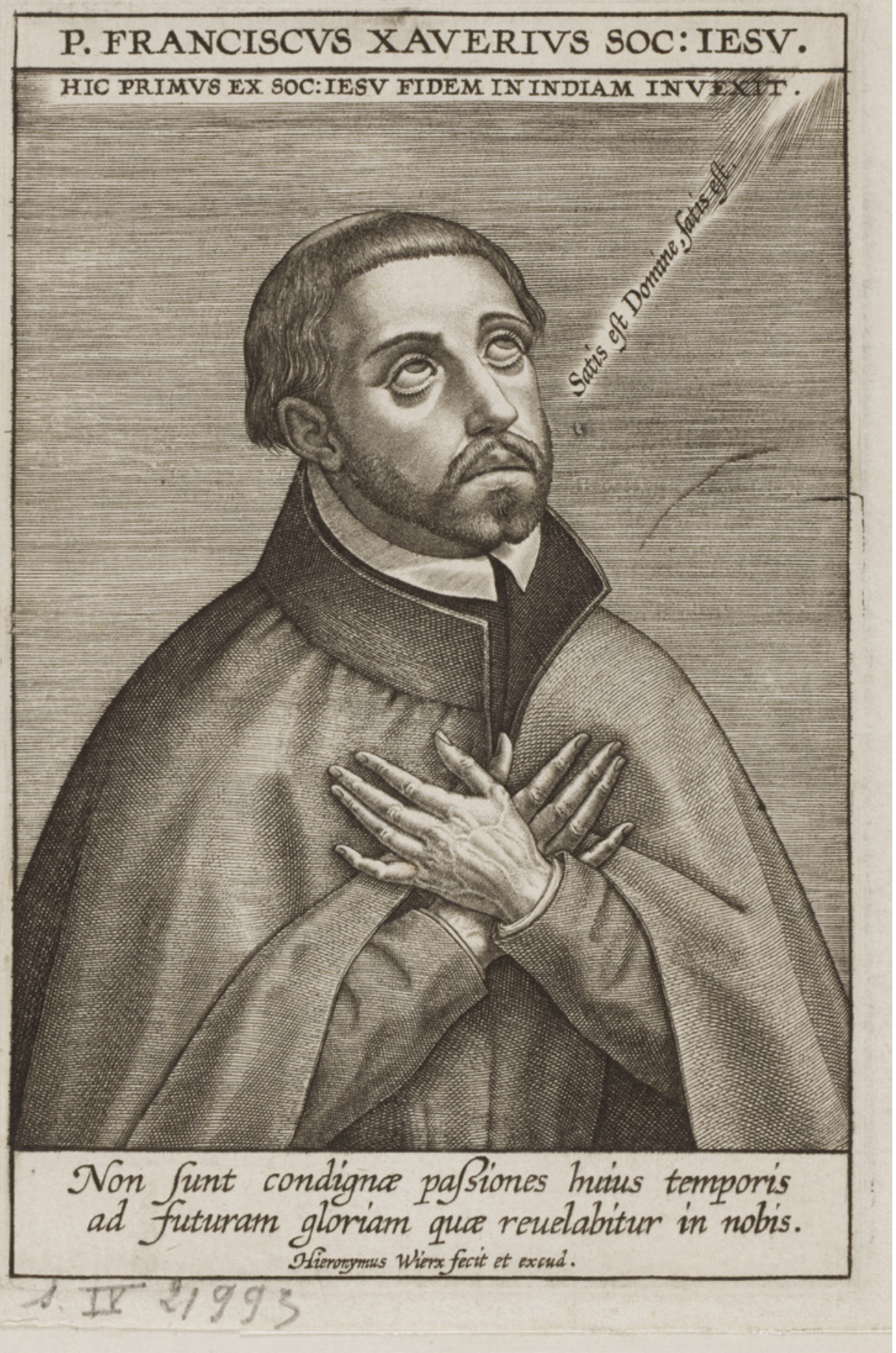

FIgure 3.26 Hieronymus Wierix, Portrait of St. Francis Xavier with Hands Crossed, c.1596-1619, engraving (call no. EST 8º-Wierix-M.-H. 1810-S.IV 21993). Brussels, Bibliothèque Royale de Belgique, Prints and Drawings PHOTO: (C) BIBLIOTHÈQUE ROYALE DE BELGIQUE 
they would without this occasion." ${ }^{327}$ As the twentieth-century artist Francis Bacon (1909-92) has noted, the representation of the crucified Christ needed to convey the specificity of someone who has been "forced by circumstances into a unique situation." ${ }^{328}$ The focus had shifted from the creation of an object and the defining achievements of the saint's life to the independent encounter with the viewer, where a portrait could exploit the provisional quality of the crucifixion to place canonization in the balance before the audience's eyes.

Third, the enflamed heart in the Kobe Portrait of St. Francis Xavier pinpoints how reference to an event could recreate the subjectivity of circumstance, and in Xavier's case, this act was the miracle of the crab. During a formidable storm on the crossing from Ambon Island to the Maluku Islands in Indonesia, legend has it that Xavier threw his personal cross into the turbulent waves, asking God to use it as an instrument for peace. Suddenly the waters stilled, and when Xavier arrived on the beach of Seram Island, he was greeted by a crab bringing his cross back to him, the moment depicted by André Reinoso (fl.1610-41) in his St. Francis Xavier and the Crab Miracle at Seram Island, the thirteenth of twenty scenes from the life of Xavier commissioned for the sacristy of São Roque Church in Lisbon in 1619 (fig. 3.27). ${ }^{329}$ The miracle of the crab was not only thoroughly recounted by the Portuguese soldier Fausto Rodrigues (d.1617) at the witness hearings for Xavier's canonization in Cebu in 1608 and 1613, it was also mentioned in the second Lisbon process in 1616 and in the official papal canonization bull (1623). ${ }^{330}$ The great Xavier scholar Georg Schurhammer, S.J.

327 Hans-Georg Gadamer, Hermeneutik I: Wahrheit und Methode. Grundzüge einer philosophischen Hermeneutik, Hans-Georg Gadamer Gesammelte Werke 1, rev. ed. (Tübingen: Mohr Siebeck, 2010), 149-65; Gadamer, Truth and Method, trans. Joel Weinsheimer and Donald G. Marshall, rev. ed. (New York: Continuum, 2002), 144-59; Nicola Suthor, "Hans-Georg Gadamer: Die Okkasionalität des Porträts (196o)," in Porträt, ed. Rudolf Preimesberger, Hannah Baader, and Nicola Suthor, Geschichte der klassischen Bildgattungen in Quellentexten und Kommentaren 2 (Berlin: Dietrich Reimer Verlag, 1999), 431-39.

328 David Sylvester, ed., Interviews with Francis Bacon (London: Thames and Hudson, 2009), 26.

329 António Meira Marques Henriques, São Francisco Xavier: Vida e lenda/Saint Francis Xavier; Life and Legend (Lisbon: Museu de São Roque/Santa Casa da Misericórdia de Lisboa, 2006), 58-59; Vítor Serrão, The Legend of Saint Francis Xavier by the Painter André Reinoso: Historical, Aesthetic, and Iconological Study of a Series of Baroque Paintings in the Sacristy of Igreja de São Roque, trans. Helena Leuschner (Lisbon: Museu de São Roque/Santa Casa da Misericórdia de Lisboa, 2006), 88-89; Serrão, A lenda de São Francisco Xavier pelo pintor André Reinoso: Estudo histórico, estético e iconológico de um ciclo barroco existente na Sacristia da Igreja de São Roque (Lisbon: Santa Casa da Misericórdia de Lisboa, 1993), $82-83$.

330 Monumenta Xaveriana, 2:713; Osswald, "Entstehung einer Ikonographie des Franz Xaver," 73; Osswald, "Iconography and Cult of Francis Xavier, 1552-1640," 269-70; Georg 


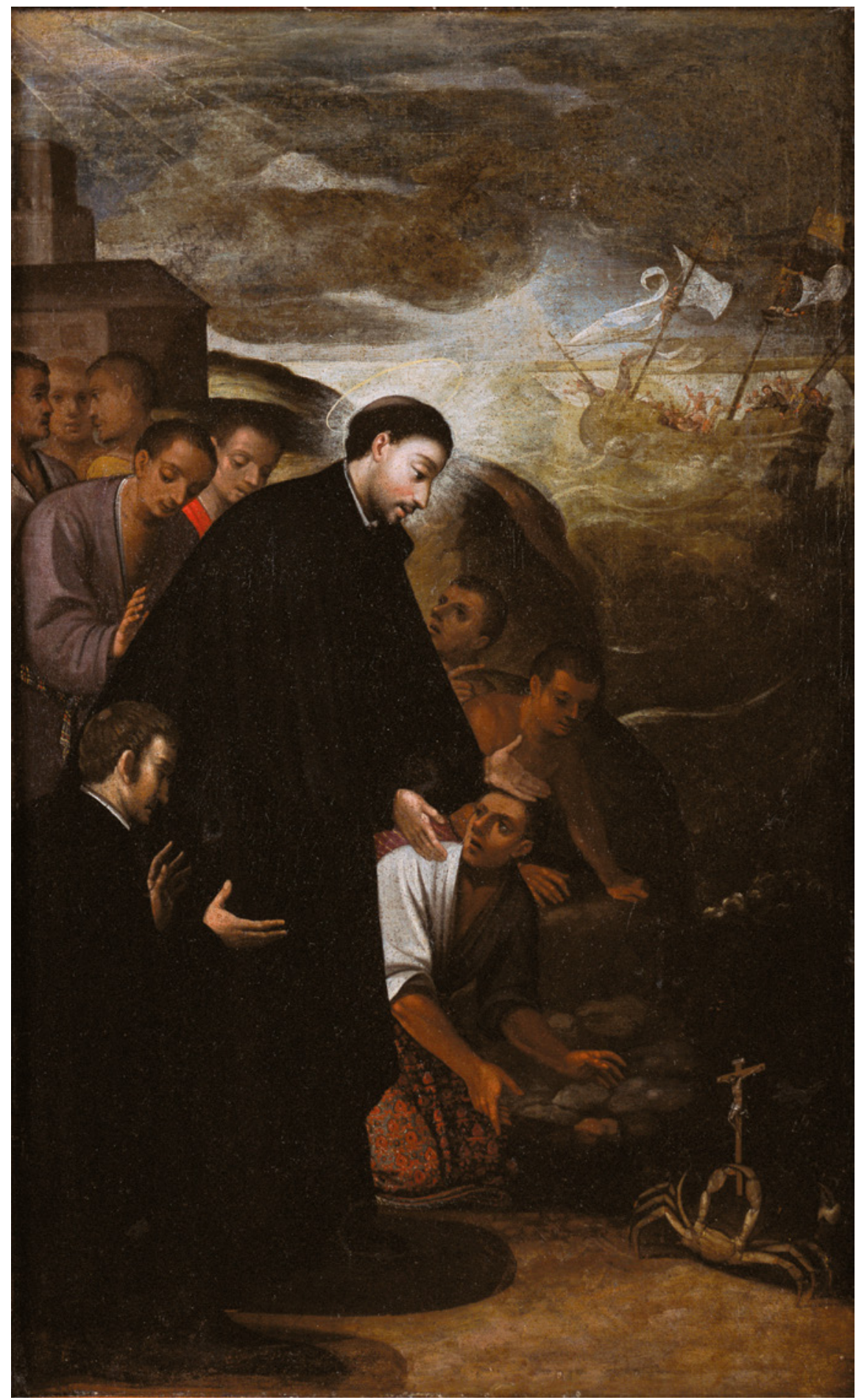

FI GURE 3.27 André Reinoso, St. Francis Xavier and the Crab Miracle at Seram Island, c.1619, oil on canvas (inv. no. 104 JM). Lisbon, Museu de São Roque, Church of São Roque, Sacristy

(C) SANTA CASA DA MISERICÓRDIA DE LISBOA. PHOTO: JÚLIO MARQUES

Mia M. Mochizuki - 9789004498228 Downloaded from Brill.come4/26/2023 01:48:39PM 


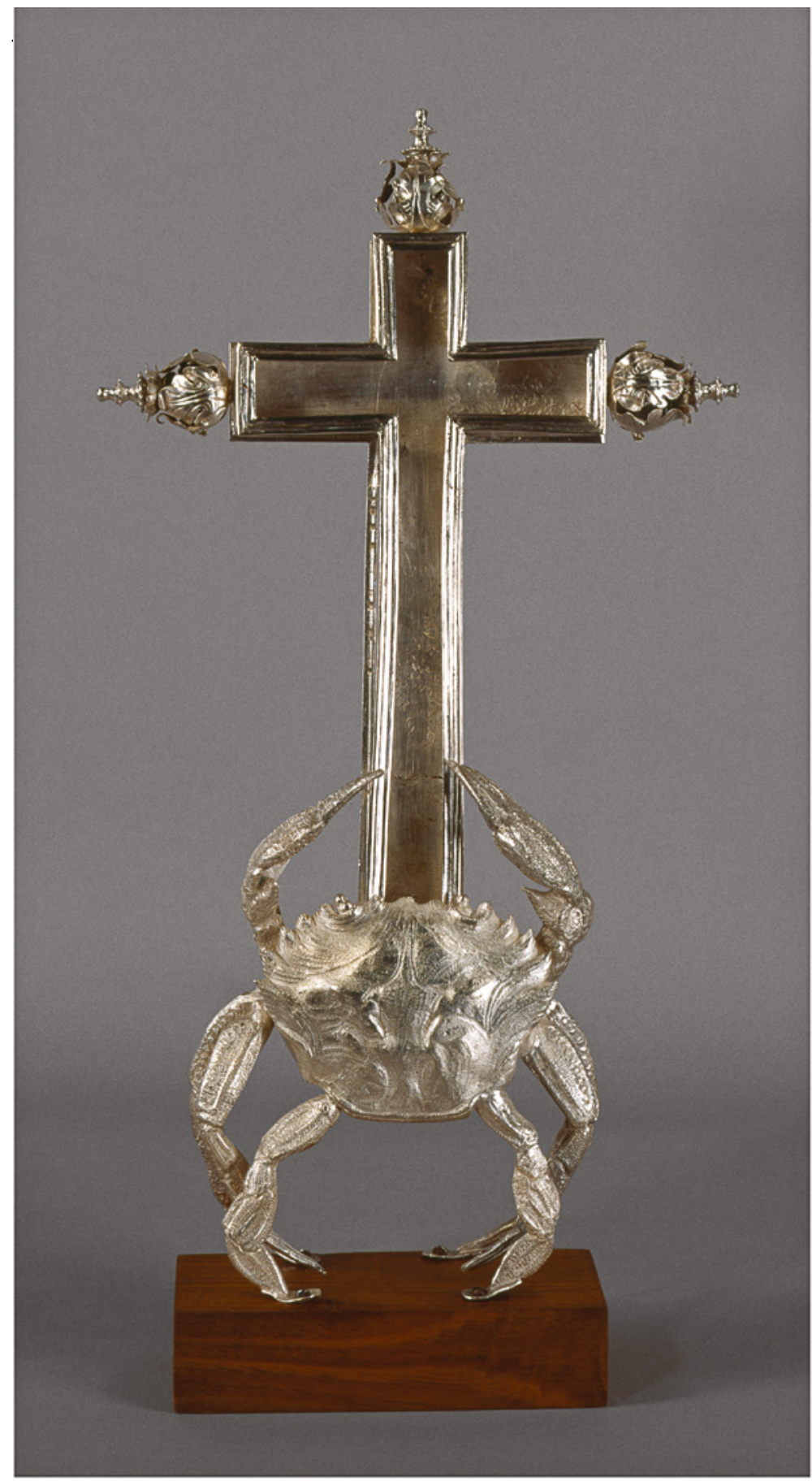

FIgure 3.28 Portuguese Artist, Cross with Crab, seventeenth century, silver (inv. no. 6210; O129). Coimbra, Museu Nacional Machado de Castro (C) DIREÇÃO-GERAL DO PATRIMÓNIO CULTURAL/ARQUIVO DE DOCUMENT AÇÃO FOTOGRÁFICA (DGPC/ADF).

PHOTO: MANUEL PALMA 
(1882-1971) argued that the story of the crab introduced devotion to the crucifix in Japan and was probably an appropriation of a local myth, the miracle itself a response to chance cultural exchange en route. ${ }^{331}$ So crucifixes of Xavier often included a crab at its base, as in a silver Cross with Crab in Coimbra (fig. 3.28). The type suggests how the crucifix in the Kobe Portrait of St. Francis Xavier had come to be attached to a heart: its stylized flames performed double duty as both fiery organ and miraculous crab in a pictorial shorthand for the two distinguishing features of his canonization campaign. ${ }^{332}$ This conflation follows Deleuze's observation in twentieth-century painting that the promotion of doubt meant form became detached from essence, the cardinal point of a crucifixion economy, and instead became tethered to the incident, the changeable, in sum, the contingent, where "Christ is besieged, and even replaced, by accidents." ${ }^{333}$ With a heart-crab motif, the Kobe portrait of this new saint could flicker back and forth between the temporally distinct occasions of canonization and miraculous act, between the status of sanctified and candidate, in a way that tactfully championed subjectivity through the cult of the face. ${ }^{334}$

The face-whose "one hundred square centimeters of the most meaningful and mutable surface on earth" Gottfried Boehm has regarded as the seat of both intimacy and inscrutability — became the embodiment of the subjective

Schurhammer, s.J., "Die Lissabonner Heiligsprechnungsprozesse Franz Xavers," Gesammelte Studien, 4, part 1:419-30, here 426-28.

331 The miracle of the crab bears a number of similarities with the legend of the ninthcentury Buddhist priest Jikaku, who used an image of a god of wisdom, Yakushi Nyorai, to calm the sea, one that was returned to him three years later by an octopus. Other legends of Xavier could also have been appropriations of local folklore encountered on their travels, like the miracle of Xavier turning salt water into fresh water from a Malaysian legend. Henriques, São Francisco Xavier, 50-51; Georg Schurhammer, S.J., "Das Krebswunder Xavers: Eine buddhistische legende?," Gesammelte Studien, 3:537-62, with a table of comparable events in the stories, 545; Schurhammer, "A New Life of Saint Francis Xavier," Gesammelte Studien, 3:129-42, here 138-40; Schurhammer, "Xaveriuslegenden und Wunder kritisch untersucht," Gesammelte Studien, 3:249-70, here 254-57, 265-66; Serrão, Legend of Saint Francis Xavier by the Painter André Reinoso, 80-81; Serrão, Lenda de São Francisco Xavier pelo pintor André Reinoso, 74-75.

332 Vlam understood the flaming heart and crucifix combination as a reference to Xavier pressing the crucifix Ignatius had given him to his breast when he died on December 3, $155^{2}$. Georg Schurhammer, S.J., "Die Kruzifixe des Heilgen Franz Xaver," Gesammelte Studien, 4 , part 1:405-9, pl. 23-24; Vlam, "Portrait of S. Francis Xavier in Kobe," 55-56.

333 Gilles Deleuze, Francis Bacon:The Logic of Sensation, trans. Daniel W. Smith (Minneapolis: University of Minnesota, 2003), 100-1.

334 Donald Weinstein and Rudolph M. Bell, Saints \& Society: The Two Worlds of Western Christendom, 1000-1700 (Chicago: University of Chicago Press, 1982), 143. 
image. ${ }^{335}$ Another printed Portrait of St. Ignatius with a Crucifix by Hieronymus Wierix, now in a close-up view, aligns with Karl Rahner's observation that the desire to communicate with God "face-to-face," in the personhood accented in Nadal's Evangelicae, was fulfilled by the crucifixion (fig. 3.29). ${ }^{336}$ De Certeau has noted how the Spiritual Exercises in general, and the crucifixion in particular, was a narrative of mystery rooted in alterity, one that, due to the Society's commitment to global mission, would come to absorb the faces of other human beings into its equation. ${ }^{337}$ The dissemination of this print in the saint's canonization campaign gave rise to pictures such as a Portrait of Hasekura Tsunenaga with a Crucifix, c.1615, a rare depiction of a non-European Christian in imitatione Ignatii (fig. 3.30). ${ }^{338}$ Now, however, conversion was emphasized over canonization, Tsunenaga portrayed in three-quarter pose with a sword, over cross or biretta, while the crucifix is obscured in profile. The inscription of its source print cited Ignatius's "conversion" when he became a Jesuit, in the spirit of the "all for all" ("Omnibus omnia") motto of the Imago's Societatis operarij emblem: "Everything is done for everyone so that all may benefit. Died in the year of the Lord [15] 56 at the age of sixty-five. Converted [at the age of] thirty-five" ("Omnibus omnia factus est vt omnes lucrifaceret. / Obijt Anno Domini 56. AEtatis 65. Conversus 35."). The "ex-position" of the subject, from the vantage point of crucifixion and a Christian outside Europe, encouraged the viewer to "stand outside him- or herself" and adopt the "exo-," or "outside," as a starting place for interpretation. It was a "way of seeing" congruent with "the ability to conceive otherwise" advocated by the French naval doctor and

335 Gottfried Boehm, "Lebensspur: Zum Bildnis im Zeitalter der Moderne," in Dem Porträt auf der Spur: Serienbild und Variation in Zeiten der Moderne, ed. Patricia Rochard, exh. cat. (Mainz: Internationale Tage/Boehringer Ingelheim, Alten Rathaus der Stadt Ingelheim and Verlag Hermann Schmidt, 2000), 10-23, here 10; Jonathan Cole, About Face (Cambridge, MA: MIT Press, 1998), 201.

336 König-Nordhoff, Ignatius von Loyola, 70-71, 207-14; Mauquoy-Hendrickx, Estampes des Wierix, 3, part 1:370, pl. 271, fig. 1841; K. Rahner, Spiritual Exercises, 114-15.

337 De Certeau, "Espace du désir ou le 'fondement' des Exercices spirituels," 126-28; de Certeau, "Space of Desire," 95-96.

338 Hasekura Tsunenaga (1571-1622) led the second and last delegation to Europe, the Keichō embassy (1613-20), assuming the name "Felipe Francesco Faxicura" when he was baptized by the personal chaplain of Philip III of Spain (1578-1621, r.1598-1621) in Madrid, with the duke of Lerma as his godfather, in 1615, and he was made an honorary citizen of Rome on January 2, 1616. Giuseppe Pittau, s.J. et al., eds., Da Sendai a Roma: Un'ambasceria giapponese a Paolo $V$, exh. cat. (Rome: Museo Nazionale d'Arte Orientale, Museo Nazionale di Castel Sant'Angelo, Museo di Sendai, and Office Move/Associazione Scambi Culturali Internazionali, 1990), 192. 


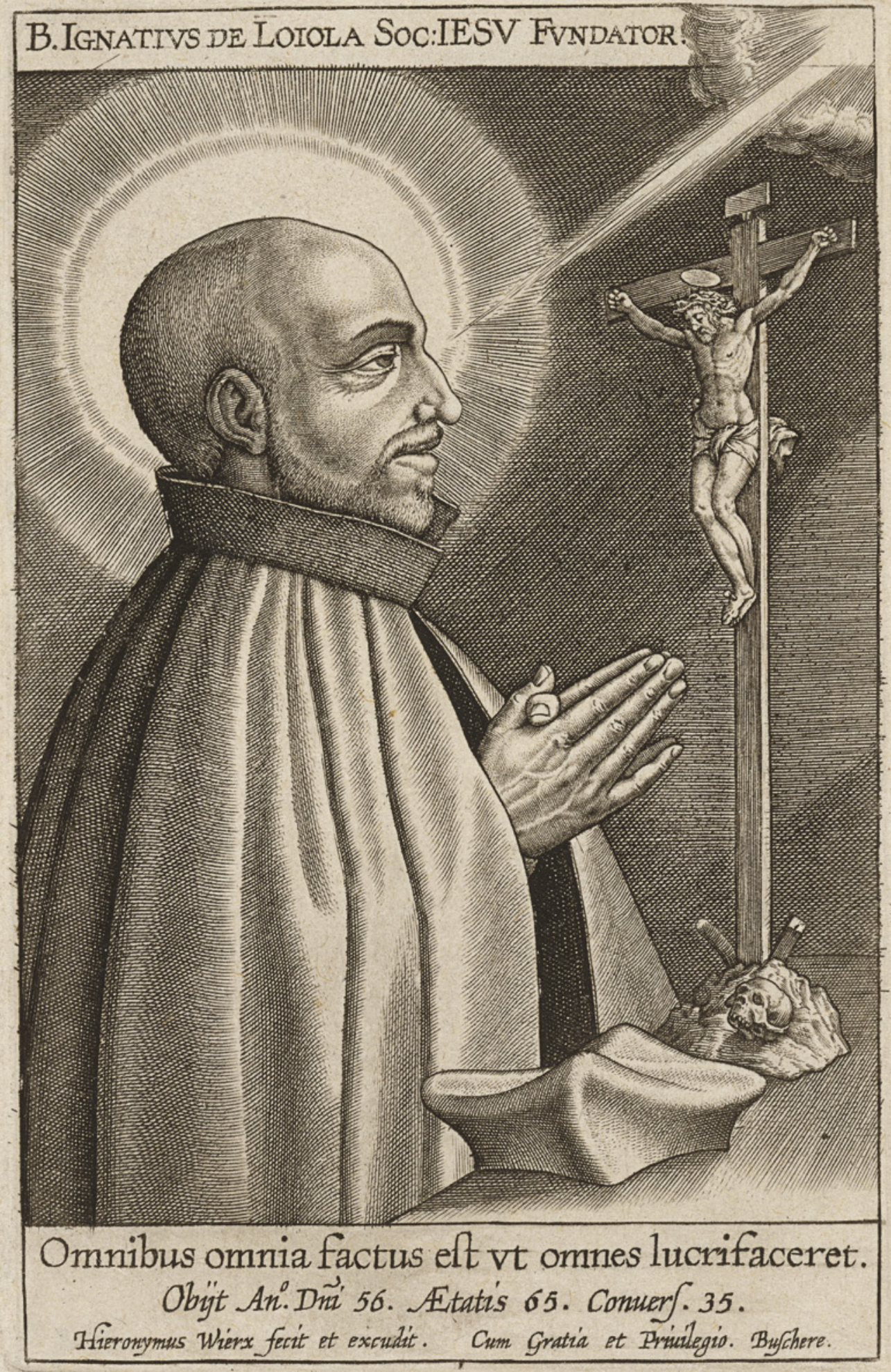




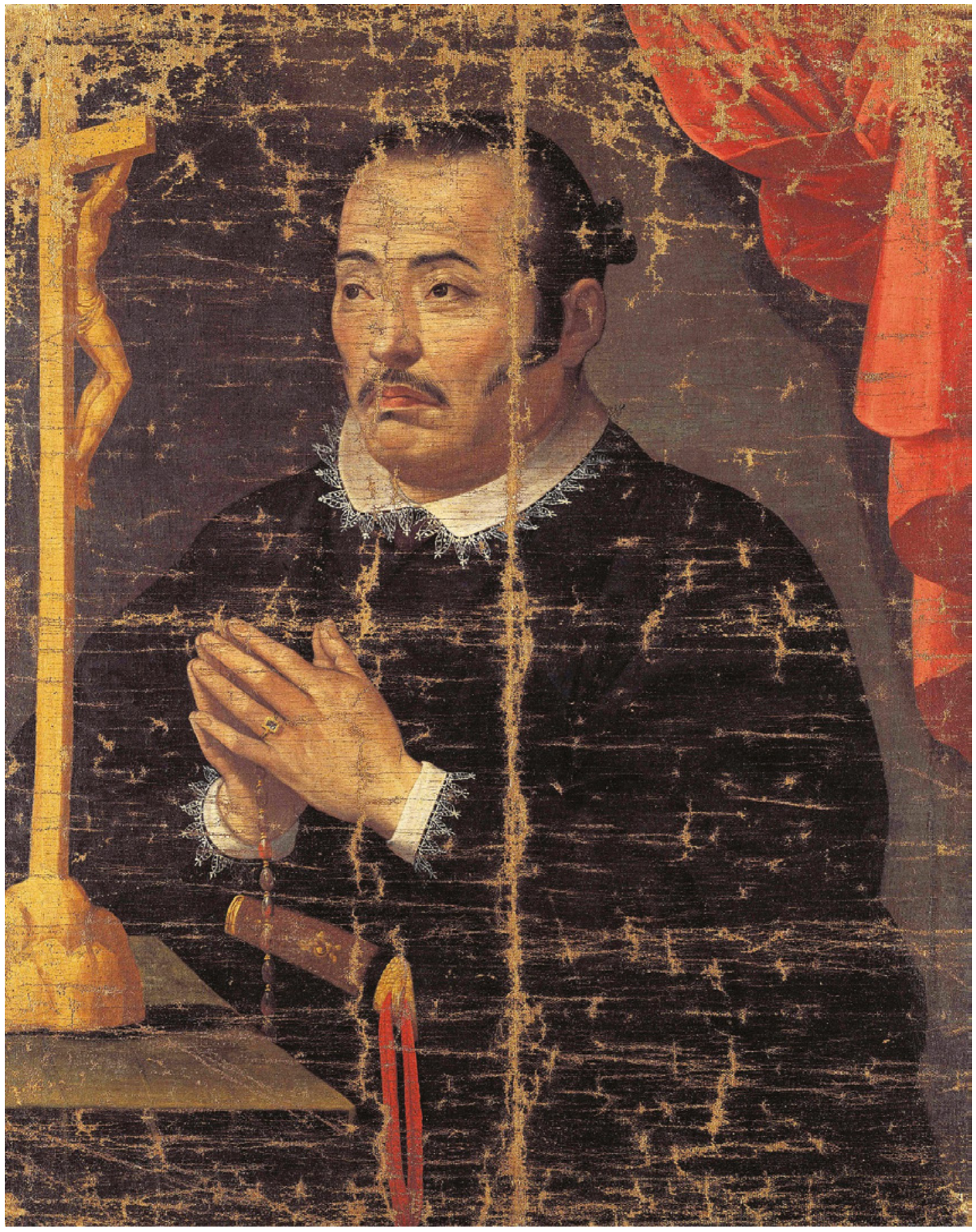

FIGURE 3.30 Niccolò School, Portrait of Hasekura Tsunenaga with a Crucifix, c.1615, oil on canvas. UNESCo Memory of the World Register, National Treasures of Japan Collection, "Materials Related to the Keichō Mission to Europe." Sendai, Sendai City Museum PHOTO: (C) SENDAI CITY MUSEUM

$\leftarrow \quad$ FIGURE $3.29 \quad$ Hieronymus Wierix, Portrait of St. Ignatius with a Crucifix, before 1619, engraving (inv. no. 2006, U. 559). London, British Museum PHOTO: (C) THE TRUSteEs OF THE BRITISH MUSEUM Mia M. Mochizuki - 9789004498228 
ethnographer Victor Segalen (1878-1919), himself educated at Jesuit schools. 339 Crucifixion-indebted exoticism was a by-product of the post-Tridentine universal Roman Catholic Church, and the crucified other can provide an early modern correction to romantic and colonial definitions of the word and a still trenchant defense of humanism today. For Jesuits, the portrait was not only the instantiation of incarnation theology; through overseas experience, they recognized this genre could also metabolize the crucifixion's effect on the individual, to invest imagery with an uncanny "consciousness" born of sacrifice, self, and subjectivity. ${ }^{340}$ The crucifixion economy had reoriented the picture to the internal realities of its personae, where Karl Rahner's description of choice in the Spiritual Exercises - "the actual subjectivity of the subject becomes the theme of the subject's focus, instead of being merely the mode through which the subject realizes itself"-reads much like what would become one of the tenets of modern painting. ${ }^{341}$

\section{Part 4: In Place of a Conclusion}

\subsection{What If There Was No Jesuit Art?}

A last selection brings the discussion full circle to the Gesù in Rome, if this time to the private rooms of St. Ignatius of Loyola in the International College. A memorial portrait, St. Ignatius in His Study, c.16og, by Jusepe de Ribera (1591-1652), suggests that the best way to recover the thought of Ignatius, and by extension the historical Society of Jesus, may be through books (fig. 4.1). The scholarly Ignatius is pictured writing at his desk, pausing to look up at the viewer after completing a page of a manuscript: "Societas Iesu" beneath the heading "A.M.D.G.," the abbreviation for "Ad maiorem Dei gloriam," his appeal for all efforts to serve the greater glory of God. This is a portrait that prompts biography, historiography, and perhaps hagiography. To date, the study of the early modern Society of Jesus has been dominated by a textual perspective, and it is true, Ignatius's biretta sits atop a stack of books, if it is less frequently

339 Kobayashi-Sato and Mochizuki, Gurōbaru jidai no yoake, 122-51; Kobayashi-Sato and Mochizuki, "Perspective and Its Discontents or St. Lucy's Eyes," 21-48; Nancy, Portrait, ix, 14, 18, 20, 41, 59; Victor Segalen, Essay on Exoticism: An Aesthetics of Diversity, trans. and ed. Yaël Rachel Schlick (Durham, NC: Duke University Press, 20o2), 16, 18, 61-64, $67-68,7$.

340 Victor I. Stoichita, The Self-aware Image: An Insight into Early Modern Meta-painting, trans. Anne-Marie Glasheen (Cambridge: Cambridge University Press, 1997).

341 Karl Rahner, S.J., "Being Open to God as Ever Greater," Theological Investigations, 7:25-46, here 38; Sluhovsky, Becoming a New Self, 94. 
FIG URE 4.1 Jusepe de Ribera, St. Ignatius in His Study, c.16o9, oil on canvas. Rome, Collegio Internazionale del Gesù, Rooms of St. Ignatius of Loyola

PHOTO: (C) FOTO VASARI ROMA/ALESSANDRO VASARI (INV. NO. ALV7035-2)

noticed that his hat is placed at the foot of a crucifix, akin to its position in the Wierix engravings at the end of the last chapter (figs. 3.22, 3.29). The presence of a crucifix in St. Ignatius of Loyola in His Study reminds us, however, that there were always at least two threads to Ignatius's legacy, the verbal and the visual. Records of early Jesuits, across a miscellany of documents-letters, institutional papers, spiritual diaries, and indipetae or requests for missionary service-consistently cite the presence of images, from everyday decoration to the pervasive use of imagery, both actual and imagined, as an impetus to prayer and missionary exhortation. Indeed, it is an artistic heritage that the 
twenty-eighth superior general, Pedro Arrupe (1907-91, in office 1965-83), encouraged Jesuits to reclaim after nineteenth- and twentieth-century ambivalence had caused it to be viewed with a degree of circumspection even within the Society. ${ }^{342}$

For every St. Ignatius of Loyola in His Study, there was a St. Francis Xavier Directing the Construction of a Building, by Luca Giordano (1634-1705), that commemorated the passionate energies and excitement of the process of artmaking, and together, these two paintings exemplify two halves of a single critical tradition (fig. 4.2). The hands of Xavier-one arm outstretched, the other lifted in an emphatic beckoning gesture-draw the attention of both the kneeling figure in the lower-left corner and the extra-pictorial viewer to the site of creative work. The light of the Holy Spirit cascades down to illuminate the stages of production, from the heated gesticulations and intense concentration of the men in the right foreground, who debate the pros and cons of a visionary design, to the heavy labor required to bring such plans to fruition behind them. And although the location of the scene is left only vaguely articulated, a plausible reference to the Jesuit Church and College of St. Paul in Goa, it is noteworthy that it is Xavier, the Society's missionary par excellence, who drives the model primarily from outside the center of picture and discourse. Today, this scene acts as a vehement reminder to scholars not to overlook the remnants of a magnificent inheritance, one whose monumental stone ruins have often survived less well than the unassuming slips of paper that have enjoyed the benefit of consistent underestimation. So although it may seem surprising to state, in light of the explosion of the bibliography on Jesuit art in recent decades, compared to the writings of the Society of Jesus, many objects and topics in early modern Jesuit visual culture have yet to receive the critical analysis they richly warrant.

342 The Thirty-First General Congregation of the Society of Jesus, "Section V: The Apostolate, Decree 30; Cultivating the Arts in the Society," 556.3 (November 15, 1966): "The 31st General Congregation, taking into consideration both the tradition of the Society and the signs of the times, and aware of the importance of the arts for building up the kingdom of God, wishes to encourage the activity of its members who toil in this field for the greater glory of God." Pedro Arrupe, s.J., "Art and the Spirit in the Society of Jesus," Studies in the Spirituality of the Jesuits 5, no. 3 (April 1973): 83-92; "Decree 30: Cultivating the Arts in the Society," General Congregation of the Society of Jesus 31 (1965-66); https:// jesuitportal.bc.edu/research/documents/1966_decree3ogc31/ (accessed March 15, 2021); Clement J. McNaspy, S.J., "Art in Jesuit Life," Studies in the Spirituality of the Jesuits 5, no. 3 (April 1973): 93-111; John W. Padberg, S.J., ed., Jesuit Life and Mission Today: The Decrees and Accompanying Documents of the 3ist-35th General Congregations of the Society of Jesus (St. Louis, MO: Institute of Jesuit Sources, 20o9), 28, 179-80. 
But what if Giordano's portrayal of Xavier's efforts to build a Jesuit art were stymied, if there had been no Jesuit art bequeathed to posterity? Like a Christianity without crucifixion, the question applies the principles of fictional absence to underscore decisive turning points in history, an apt "nonending" for a volume meant to support original research, where a conclusion would be premature and possibly antithetical to its objective. The answer, a narrative without Jesuit art, would lead almost certainly to a considerable diminishment of the Society's corpus of non-verbal expression, and arguably, to a loss of the order's internal identification and external recognition. For art history, the baroque would have remained under-conceptualized, perhaps associated with different elements from what are identified with it now, if the category came to exist at all. Most dramatically, there would have been no coherent early modern global artistic creation, just sporadic and circumscribed appearances with a large-scale infrastructure only emerging later, one that would have adhered to the code of other institutions, like the Protestant-inflected mercantile humanism propagated by the Dutch East and West India Companies during the seventeenth century. That the Society of Jesus was able to inaugurate a comprehensive working apparatus over a halfcentury earlier relied on the serendipitous intersection of unique historical conditions: a post-Reformation religious order with a deep-seated commitment to the arts and a vocation to world running headlong into the technological means with which to achieve it. Without the Jesuit investment in art around the globe, western visual culture, indispensable when non-linguistic engagement was at a premium, would have been introduced to societies in different circumstances and with other effects.

My own interest in a continuum of Jesuit art touches on its style and iconography, but only in passing; the primary concern of this book has focused on how it functions. By this I mean not simply didactically and catechetically, approaches that have mainly emulated textual inquiry, but rather how Jesuit art performs both as objects and in a history of art leavened by an early Ignatian spirituality. Three books with innovative uses of imagery-the Spiritual Exercises, the Evangelicae historiae imagines, and the Imago primi saeculi Societatis Iesv-provide insight into the operational principles that Jesuit art would reap. They act as an appeal for a canon that does not favor one medium over another or let an aspect of the tradition serve as a metonymy for the whole. This book therefore concludes, first, with the observation that the print production of the Society of Jesus, a topic largely treated by historians of Northern European art, should be considered a requisite supplement to the classic historiography of Italian architectural history for the formation of a Jesuit art. 


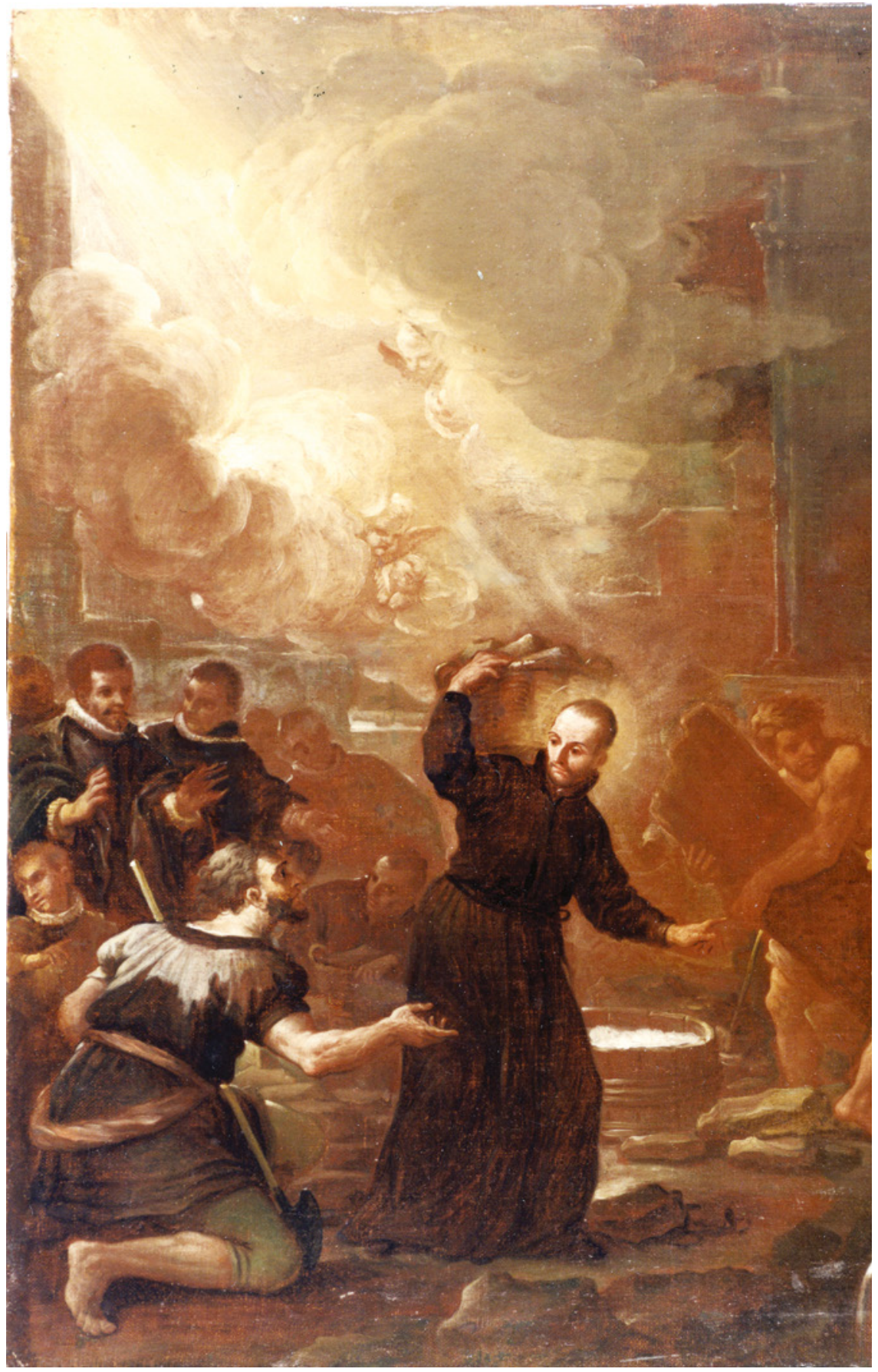

FIGURE 4.2 Luca Giordano, St. Francis Xavier Directing the Construction of a Building, late seventeenth century, oil on canvas (inv. no. 86o.1.577). Ville d'Aix-en-Provence, Musée Granet

(C) MUSÉE GRANET. PHOTO: BERNARD TERLAY 


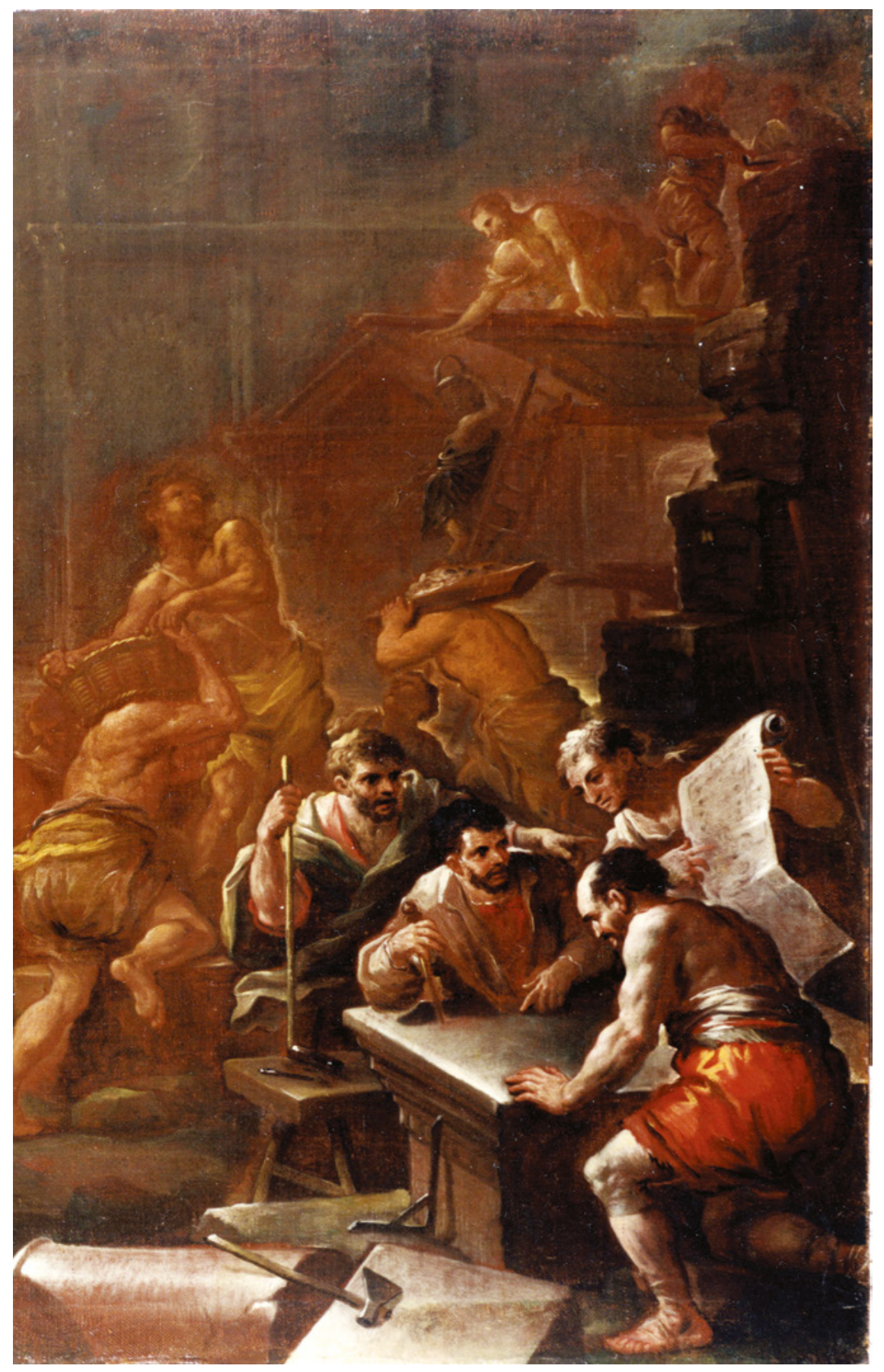


The prominence of prints was due in great part to the worldwide forum in which the Society conducted its activities. Consequently, and second, this study demonstrates the paramount importance of the global aspects of Jesuit art in the order's cultural contribution, apparent in the stylistic and iconographic manifestations of exploration certainly, but especially palpable in the ways Jesuit imagery constructed meaning within the picture plane through the lens of place. Locus and imago were essential, and inseparable, components of Jesuit self-formation. The incorporation of the world into Jesuit art on a structural level was how it connected to the Society's endeavors at large. Jesuits did not simply expand the arena of their ministries geographically when they set up overseas outposts; the post-Tridentine dream of a universal Roman Catholic Church was integral to an Ignatian charism. O'Malley has reminded scholars that the global missions were a cornerstone not only for the history and logistics of the Society, but also for its spirituality: "Any study of early Jesuit spirituality that ignores the enterprises and cultural magnanimity of missioners like these [i.e., Matteo Ricci $\left(155^{2-1610}\right)$ in China or Roberto de Nobili $\left(1577^{-1656)}\right.$ in India] misses a central element of the tradition."343

The effect of this global initiative was an art whose significance extended beyond any one order or particular religion. Thus this account closes, third, with the assertion that Jesuit art matters to art history because the world's first systemic global art production constituted a strategic juncture in the history of representation. Just as Jesuit art formed many a young novice, it shaped modern art in its own image, as assiduously networked, technologically curious, and preternaturally subjective. Its genius lay in its ability to act as a mirror in the "Omnibus omnia" sense of the Imago's Societatis operarij emblem: despite the centuries past and oceans crossed, a global Jesuit art is one of the earliest cases where we have the ability to see something reflected that begins to approach the many faces of ourselves (fig. 2.27). For ultimately, Jesuit art retains its relevance, as timely for the sixteenth as the twenty-first century, because it was a call to explicitly acknowledge a worldview, where to look outward, taking this generation's désenclavement, or opening, of the field to heart methodologically and geographically, was to look forward.

\section{Bibliography}

Alcalá, Luisa Elena, ed. Fundaciones jesuíticas en Iberoamérica. Madrid: Fundación Caja Madrid and Ediciones El Viso, 2002.

343 O'Malley, "Early Jesuit Spirituality," 18. 
Alciato, Andrea. Emblematum liber. Augsburg: Heinrich Steyner, 1531.

Alden, Dauril. The Making of an Enterprise: The Society of Jesus in Portugal, Its Empire and Beyond, 1540-1750. Palo Alto: Stanford University Press, 1996.

Aleni, Giulio. Tian zhu jiang sheng chu xiang jing jie. Jinjiang: Jing Jiao Tang, 1637.

Allgemeine deutsche Real-Encyklopädie für die gebildeten Stände: Conversations-Lexikon. Vol. 7. 9th ed. Leipzig: Brockhaus, 1845 .

Aono, Junko, Sumiko Imai, Mia M. Mochizuki, and Noriko Mochizuki, eds. Utsurō keishō to shikaku geijutsu: Kobayashi Yoriko-sensei taishoku kinen ronbun-shū. Tokyo: Yasaka Shobo, 2019.

Appuhn-Radtke, Sibylle. "Ordensapologetik als Movens positivistischer Erkenntnis: Joseph Braun S.J. und die Barockforschung.” Archivum historicum Societatis Iesu 79 (2010): 299-320.

Appuhn-Radtke, Sibylle. Das Thesenblatt im Hochbarock: Studien zu einer graphischen Gattung am Beispiel der Werke Bartholomäus Kilians. Weißenhorn: Anton H. Konrad Verlag, 1988.

Archivum historicum Societatis Iesu. Rome: Archivum Romanum Societatis Iesu, 1932present. http://www.sjweb.info/arsi/en/publications/ahsi/ (accessed March 15, 2021).

Aristotle. Art of Rhetoric. Translated by John Henry Freese and revised by Gisela Striker. Loeb Classical Library 193. Rev. ed. Cambridge, MA: Harvard University Press, 2020.

Aristotle. On the Soul, Parva naturalia, and On Breath. Translated by W.S. Hett. Loeb Classical Library 288. Rev ed. Cambridge, MA: Harvard University Press, 1957 [1936]. Arrupe, Pedro, s.J. "Art and the Spirit in the Society of Jesus." Studies in the Spirituality of the Jesuits 5, no. 3 (April 1973): 83-92.

Aschenbrenner, George, s.J. "Becoming Whom We Contemplate." The Way, Supplement $5^{2}$ (Spring 1985): 30-42.

Aschenbrenner, George, s.J. Consciousness Examen. Chicago: Loyola Press, 2007.

Bailey, Gauvin Alexander. The Andean Hybrid Baroque: Convergent Cultures in the Churches of Colonial Peru. Notre Dame, IN: University of Notre Dame Press, 2010.

Bailey, Gauvin Alexander. Art on the Jesuit Missions in Asia and Latin America, 15431773. Toronto: University of Toronto Press, 1999.

Bailey, Gauvin Alexander. Between Renaissance and Baroque: Jesuit Art in Rome, 15651610. Toronto: University of Toronto Press, 2003.

Bangert, William, s.J. Jerome Nadal, S.J., 1507-1580: Tracking the First Generation of Jesuits. Edited by Thomas M. McCoog, S.J. Chicago: Loyola University Press, 1992.

Barbieri, Sergio. Empresas sacras jesuíticas: Córdoba, Argentina. Historia de la arquitectura de Córdoba 5. Cordoba: Fundación Central, 2003.

Barletta, Vincent, ed. "The Lusophone Baroque." Ellipsis: Journal of the American Portuguese Studies Association, Special Issue, 12 (2014).

Barnet, Sylvan. A Short Guide to Writing about Art. 11th ed. Boston: Pearson Education, $2013[1981]$. 
Barrett, Denis Cyril, s.J. “A 'Jesuit Style' in Art?” Studies: An Irish Quarterly Review 45, no. 179 (Autumn 1956): 335-41.

Barry, William A., s.J. Finding God in All Things: A Companion to the Spiritual Exercises of St. Ignatius. Notre Dame, IN: Ave Maria Press, 1991.

Bartoli, Daniello. Degli uomini e de' fatti della Compagnia di Gesù: Memorie istoriche del p. Daniello Bartoli della medesima Compagnia; Opera postuma. 5 Vols. Turin: Giacinto Marietti, $1847-56$.

Bartoli, Daniello. Dell'historia della Compagnia di Giesù: Il Giappone, seconda parte dell'Asia. Rome: Ignazio de' Lazzari, 166o.

Baumstark, Reinhold, ed. Rom in Bayern: Kunst und Spiritualität der ersten Jesuiten. Exhibition Catalog. Munich: Bayerisches Nationalmuseum, 1997.

Begheyn, Paul, s.J., Bernard Deprez, Rob Faesen, s.J., and Leo Kenis, eds. Jesuit Books in the Low Countries, 1540-1773: A Selection from the Maurits Sabbe Library. Leuven: Peeters, 2009.

Belting, Hans. Likeness and Presence: A History of the Image before the Era of Art. Translated by Edmund Jephcott. Chicago: University of Chicago Press, 1994.

Belting, Hans, Andrea Buddensieg, and Peter Weibel, eds. The Global Contemporary and the Rise of New Art Worlds. Cambridge, MA: MIT Press, 2013.

Benjamin, Walter. Gesammelte Schriften. Edited by Rolf Tiedemann and Hermann Schweppenhäuser. 14 Vols. 8th ed. Frankfurt am Main: Suhrkamp Verlag, 2017 [1972-91].

Benjamin, Walter. Illuminations. Edited and translated by Hannah Arendt. New York: Schocken Books, 1969.

Benjamin, Walter. Selected Writings. Edited by Michael W. Jennings, Marcus Bullock, Howard Eiland, and Gary Smith, and translated by Rodney Livingstone, Edmund Jephcott, and Howard Eiland. 5 Vols. Cambridge, MA: Harvard University Press, 1996-2003.

Bernard-Maître, Henri, s.J. "L'art chrétien en Chine du temps du Père Matthieu Ricci." Revue d'histoire des missions 12 (June 1935): 199-229.

Bhabha, Homi. The Location of Culture. London: Routledge, 1994.

Boer, Wietse de, Karl A.E. Enenkel, and Walter S. Melion, eds. Jesuit Image Theory. Intersections: Interdisciplinary Studies in Early Modern Culture 45. Leiden and Boston: Brill, 2016.

Bohner, Alfred. "Tenchi hajimari no koto: Wie Himmel und Erde entstanden." Monumenta Nipponica 1, no. 2 (July 1938): 465-514.

Bolland, Jean de, and Godfried Henskens, eds. Imago primi saeculi Societatis Iesv. Antwerp: Plantin Press under Balthasar Moretus, 1640.

Borja y Enríquez, duque de Gandia, Juan de. Sanctus Franciscus Borgia, quartus Gandiae dux et Societatis Jesu praepositus generalis tertius (Monumenta Borgia). Edited by Cecilio Gómez Rodeles, S.J. 5 Vols. Madrid: Typis Augustinus Avrial and Gabrielis Lopez del Horno, 1894-1911. 
Boschloo, Anton W.A., Jacquelyn N. Coutré, Stephanie S. Dickey, and Nicolette C. Sluijter-Seijffert, eds. Aemulatio: Imitation, Emulation, and Invention in Netherlandish Art from 1500 to 1800; Essays in Honor of Eric Jan Sluijter. Zwolle: Waanders, 2011.

Bösel, Richard. Jesuitenarchitektur in Italien, 1540-1773: 1. Die Baudenkmäler der römischen und der neapolitanischen Ordensprovinz. Vienna: Verlag der Österreichischen Akademie der Wissenschaften, 1985.

Bösel, Richard. Orazio Grassi: Architetto e matematico gesuita; Un album conservato nell'Archivio della Pontificia Università Gregoriana a Roma. Rome: Argos, 2004.

Bösel, Richard. "Typus und Tradition in der Baukultur gegenreformatorischen Orden." Römische historische Mitteilungen 31 (1989): 239-53.

Bösel, Richard, and Lydia Salviucci Insolera, eds. Artifizi della metafora: Saggi su Andrea Pozzo. Rome: Artemide, 2011.

Bösel, Richard, and Lydia Salviucci Insolera, eds. Mirabili disinganni: Andrea Pozzo (Trento 1642-Vienna 1709); Pittore e architetto gesuita. Exhibition catalog. Rome: Istituto Nazionale per la Grafica, 2010.

Bösel, Richard, and Herbert Karner. Jesuitenarchitektur in Italien, 1540-1773: 2. Die Baudenkmäler der mailändischen Ordensprovinz. Vienna: Verlag der Österreichischen Akademie der Wissenschaften, 2007.

Bosmans, Henri, s.J. "Théodore Moretus de la Compagnie de Jésus, mathématicien (1602-1667): D’après sa correspondance et ses manuscrits." De Gulden Passer 6 (1928): 57-162.

Bothmer, Hans-Caspar von, Klaus Güthlein, and Rudolf Kuhn, eds. Festschrift Lorenz Dittmann. Frankfurt am Main: Peter Lang, 1994.

Bovio, Carlo. Ignatius insignium epigrammatum et elogiorum centuriis expressus. Rome: Ignazio de' Lazzari, 1655 .

Bowen, Karen L., and Dirk Imhof. "Publishing and Selling Jerónimo Nadal's TrendSetting Evangelicae historiae imagines and Adnotationes et meditationes in evangelia: Dealings with the Moretuses, 1595-1645." The Library, 7 th series, 20, no. 3 (September 2019): 307-39.

Branteghem, Willem van. Dat leven ons Heeren Christi Iesu figuerlijk wten text der vier Euangelisten. Antwerp: Mattheus Crom, 1537.

Braun, Joseph, s.J. Die belgischen Kirchenbauten: Ein Beitrag zur Geschichte des Kampfes zwischen Gotik und Renaissance. Freiburg im Breisgau: Herdersche Verlagshandlung, 1907. https://archive.org/stream/diebelgischenjesoobrau (accessed March 15, 2020).

Braun, Joseph, s.J. Die Kirchenbauten der deutschen Jesuiten. 2 Vols. Freiburg im Breisgau: Herdersche Verlagshandlung, 1908-1910. https://archive.org/details/bub _gb_nhdh9oB_kSsC (Vol. 1) and https://archive.org/details/diekirchenbauteno2bra uuoft (Vol. 2) (accessed March 15, 2021).

Braun, Joseph, s.J. Spaniens alte Jesuitenkirchen: Ein Beitrag zur Geschichte der nachmittelalterlichen kirchlichen Architektur in Spanien. Freiburg im Breisgau: 
Herdersche Verlagshandlung, 1913. https://archive.org/stream/spaniensaltejesuoo brauuoft (accessed March 15, 2021).

Braund, Susanna Morton, ed. and trans. Juvenal and Persius. Loeb Classical Library 91. Cambridge, MA: Harvard University Press, 2004.

Bricarelli, Carlo, s.J. "Le chiese degli antichi gesuiti in Germania." La civiltà cattolica 61, no. 4, issue 1449 (1910): 338-43.

Burckhardt, Jacob. Briefe. Edited by Max Burckhardt. 11 Vols. Basel: Benno Schwabe, 1949-66.

Burckhardt, Jacob. De Cicerone. Basel: Schweighauser'sche Verlagsbuchhandlung, 1855.

Burckhardt, Jacob. De Cicerone. Edited by Heinrich Wölfflin. Gesamtausgabe 3 and 4. Stuttgart: Deutsche Verlags-Anstalt, 1933.

Buser, Thomas. “Jerome Nadal and Early Jesuit Art in Rome." Art Bulletin 58, no. 3 (1976): 424-33.

Butler, Alban. Butler's Lives of the Saints. Edited by Herbert J. Thurston, s.J., and Donald Attwater. 4 Vols. Rev. ed. Allen, TX: Christian Classics, 1996.

Caamaño, Jesús M., ed. Relaciones artísticas entre Portugal y España. Valladolid: Junta de Castilla y León, Consejería de Educación y Cultura, 1986.

Camões, Luís Vaz de. Os Lusíadas. Edited by Emanuel Paulo Ramos. Porto: Porto Editora, 2006.

Camões, Luís Vaz de. The Lusiads. Translated by Landeg White. Oxford: Oxford University Press, 1997.

Campa, Pedro F., and Peter M. Daly, eds. Emblematic Images \& Religious Texts: Studies in Honor of G. Richard Dimler, S.J. Early Modern Catholicism and the Visual Arts Series 2. Philadelphia: St. Joseph's University Press, 2010.

Canisius, Peter. Commentarium de Verbi Dei corruptelis. Ingolstadt: David Schneider, 1573.

Canisius, Peter. Institutiones Christianae pietatis, seu parvus catechismus Catholicorum. Antwerp: Christophe Plantin, 1574 [1566].

Canisius, Peter. De Maria Virgine incomparabiliet Deigenitrice sacrosancta libriquinque. Ingolstadt: David Schneider, 1577.

Centro Interuniversitário de História da Espiritualidade and Instituto de Cultura Portuguesa, Universidade de Porto, ed. A Companhia de Jesus na Península Ibérica nos sécs. XVI e XVII: Espiritualidade e cultura; Actas do colóquio internacional, maio 2004. Porto: Universidade de Porto, 2004.

Certeau, Michel de, s.J. "L'espace du désir ou le 'fondement' des Exercices spirituels." Christus 20, no. 77 (January 1973): 118-28.

Certeau, Michel de, s.J. Histoire et psychanalyse entre science et fiction. Paris: Éditions Gallimard, 1987 .

Certeau, Michel de, s.J. “The Space of Desire." Translated by Michelle Suderman. “Arte y espiritualidad jesuitas." Artes de México, Edición Especial, 70 (2004): 93-96. 
Chong, Alan, ed. Christianity in Asia: Sacred Art and Visual Splendour. Exhibition catalog. Singapore: Asian Civilisations Museum, 2016.

Chorpenning, Joseph F., O.s.F.s., ed. Emblemata sacra: Emblem Books from the Maurits Sabbe Library, Katholieke Universiteit Leuven. Exhibition catalog. Philadelphia: St. Joseph's University Press, 2006.

Christ, Yvan. “Le ‘style jésuite' n'existe pas.” Jardin des arts 86 (1962): 44-49.

Christin, Olivier, Fabrice Flückiger, and Naïma Ghermani, eds. Marie mondialisée: L'atlas Marianus de Wilhelm Gumppenberg et les topographies sacrées de l'époque moderne. Neuchâtel: Éditions Alphil-Presses Universitaires Suisses, 2014.

Cienfuegos, Álvaro. La heroyca vida, virtudes y milagros del grande S. Francisco de Borja. Madrid: La Viuda de Juan García Infanzón, 1717.

Cole, Jonathan. About Face. Cambridge, MA: MIT Press, 1998.

Conwell, Joseph F., s.J. Walking in the Spirit: A Reflection on Jerónimo Nadal's Phrase "Contemplative Likewise in Action." St. Louis, MO: Institute of Jesuit Sources, 2003.

Corsi, Elisabetta. La fábrica de las ilusiones: Los jesuitas y la difusión de la perspectiva lineal en China (1698-1766). Mexico City: El Colegio de México, Centro de Estudios de Asia y África, 2004.

Costere, Frans de. Vyftich meditatien van de gantsche historie der Passie en des lijdens Ons Heeren Jesu Christi. Antwerp: Christophe Plantin, 1587.

Cowley, Robert, ed. The Collected What If? Eminent Historians Imagining What Might Have Been. New York: G.P. Putnam's Sons, 2001.

Coupeau, Carlos, S.J. From Inspiration to Invention: Rhetoric in the Constitutions of the Society of Jesus. St. Louis, MO: Institute of Jesuit Sources, 2010.

Dacos, Nicole, and Cécile Dulière, eds. Italia Belgica. Institut Historique Belge de Rome Études d'Histoire de l'Art 9. Turnhout: Brepols, 2005.

Dainville, François de, s.J. "La légende du style jésuite." Études: Revue fondée en 1856 par des pères de la Compagnie de Jésus 88, no. 287 (October-December 1955): 3-16. https://gallica.bnf.fr/ark:/12148/bpt6k5720o89o.r=dainville?rk=21459;2 (accessed March 15, 2021).

D’Alleva, Anne. Look! The Fundamentals of Art History. 3rd ed. Boston: Prentice Hall, 2010 [2003].

Dalwood, Dexter, Suzanne Preston Blier, Daniela Bohde, Helen C. Evans, Sarah E. Fraser, Thomas Habinek, Tom Huhn, Jeanette Kohl, Niklaus Largier, Peter Mack, and Alex Potts. "Notes from the Field: Mimesis." Art Bulletin 95, no. 2 (June 2013): 190-211.

Daly, Peter M. The Emblem in Early Modern Europe: Contributions to the Theory of the Emblem. Farnham: Ashgate, 2014.

Daly, Peter M., and G. Richard Dimler, s.J. Corpus librorum emblematum: The Jesuit Series. 6 Vols. Montreal and Toronto: McGill-Queen's University and University of Toronto Press, 1997-present. 
Daly, Peter M., and G. Richard Dimler, s.J. The Jesuit Emblem in the European Context. Early Modern Catholicism and the Visual Arts Series 14. Philadelphia: St. Joseph's University Press, 2016.

David, Jan. Duodecim specula aliquando videre desideranti concinnata. Antwerp: Plantin Press under Jan Moretus, 1610.

David, Jan. Occasio arrepta, neglecta. Antwerp: Jan Moretus, 1605.

David, Jan. Paradisus sponsi et sponsae [...] et Pancarpium Marianum. Antwerp: Plantin Press under Jan Moretus, 1607.

David, Jan. Veridicus Christianus. Antwerp: Plantin Press under Jan Moretus, 1601.

Debray, Régis. Media Manifestos: On the Technological Transmission of Cultural Forms. Translated by Eric Rauth. London: Verso, 1996.

Dekoninck, Ralph. Ad imaginem: Statuts, fonctions et usages de l'image dans la littérature spirituelle jésuite. Geneva: Droz, 2005.

Dekoninck, Ralph. "La passion des images: La traversée des images jésuites entre Ancien et Nouveau Mondes." De zeventiende eeuw 21, no. 1 (2005): 49-63.

Dekoninck, Ralph, Juan Carlos Estenssoro, Pierre Antoine Fabre, and Walter S. Melion, eds. Genèse, structure et postérité des Evangelicae historiae imagines de Jérôme Nadal. Paris and Rome: École Française de Rome, forthcoming.

Dekoninck, Ralph and Agnès Guiderdoni-Bruslé, eds. Emblemata sacra: rhétorique et herméneutique du discours sacré dans la littérature en images. Imago Figurata Studies 7. Turnhout: Brepols, 2007.

D’Elia, Pasquale M., s.J. Le origini dell'arte cristiana cinese (1583-1640). Rome: Reale Accademia d'Italia, 1939 .

D’Elia, Pasquale M., s.J. “La prima diffusione nel mondo dell'immagine di Maria 'Salus Populi Romani'" Fede e arte 2 (October 1954): 301-11.

Deleuze, Gilles. Difference and Repetition. Translated by Paul Patton. New York: Columbia University Press, 1994.

Deleuze, Gilles. Francis Bacon: The Logic of Sensation. Translated by Daniel W. Smith. Minneapolis: University of Minnesota, 2003.

D’Episcopo, Francesco, ed. S. Bernardino di Siena, predicatore e pellegrino: Atti del Convegno nazionale di studi bernardiniani, Maiori, 20-22 giugno, 1980. Galatina: Congedo Editore, 1985 .

Didi-Huberman, Georges. Confronting Images: Questioning the Ends of a Certain History of Art. Translated by John Goodman. University Park, PA: Pennsylvania State University Press, 2005.

Dietz, Feike, Adam Morton, Lien Roggen, Els Stronks, and Marc Van Vaeck, eds. Illustrated Religious Texts in the North of Europe, 1500-1800. Farnham: Ashgate, 2014.

Dimler, G. Richard, s.J. The Jesuit Emblem: A Bibliography of Secondary Literature with Select Commentary and Descriptions. AMs Studies in the Emblem 19. New York: AMS Press, 2005. 
Dimler, G. Richard, s.J. Studies in the Jesuit Emblem. Ams Studies in the Emblem 18. New York: AMs Press, 2007.

Diniz, Sofia. "A arquitectura da Companhia de Jesus no Japão: A criação de um espaço religioso cristão no Japão dos séculos XVI e XVII.” MA thesis, Universidade Nova de Lisboa, 2007.

Diniz, Sofia. "Jesuit Buildings in China and Japan: A Comparative Study." Bulletin of Portuguese-Japanese Studies 3 (2001): 107-28.

Ditchfield, Simon. “Getting beyond 'Jesuit Thinking': The Désenclavement of Jesuit Studies Twenty Years On; Where We Are Now; A Consideration of Ines G. Županov, ed., The Oxford Handbook of the Jesuits (Oxford: Oxford University Press, 2019)." Journal of Jesuit Studies 7, no. 2 (2020): 311-22.

Ditchfield, Simon. "How Not to Be a Counter-Reformation Saint: The Attempted Canonization of Pope Gregory X, 1622-45." Papers of the British School of Rome 6o (1992): 379-422.

Ditchfield, Simon. "Thinking with Saints: Sanctity and Society in the Early Modern World." Critical Inquiry 35, no. 3 (Spring 2009): 552-84.

Ditchfield, Simon, Charlotte Methuen, and Andrew Spicer, eds. Translating Christianity. Cambridge: Ecclesiastical History Society, 2017.

Donnelly, John Patrick, s.J., ed. and trans. Jesuit Writings of the Early Modern Period 1540-1640. Indianapolis: Hackett Publishing Company, 2006.

Dru, Alexander, ed. The Letters of Jacob Burckhardt. New York: Pantheon, 1955.

Duhr, Bernhard, s.J. Geschichte der Jesuiten in den Ländern deutscher Zunge im XVI. Jahrhundert. 4 Vols. Freiburg im Breisgau: Herdersche Verlagshandlung, 1907-28.

Dür, Emil. Jacob Burckhardt als politischer Publizist. Edited by Werner Kaegi. Zurich: Fretz \& Wasmuth, 1937 .

Endean, Philip, s.J. Karl Rahner and Ignatian Spirituality. Oxford Theological Monographs. Oxford: Oxford University Press, 2001.

Enenkel, Karl A.E. The Invention of the Emblem Book and the Transmission of Knowledge, ca.1510-1610. Leiden and Boston: Brill, 2019.

Enenkel, Karl, and Walter Melion, eds. Meditatio: Refashioning the Self; Theory and Practice in Late Medieval and Early Modern Intellectual Culture. Intersections: Interdisciplinary Studies in Early Modern Culture 17. Leiden and Boston: Brill, 2011.

Executive Committee 45oth Anniversary of the Arrival of St. Francis Xavier in Japan, ed. St. Francis Xavier: An Apostle of the East. 2 Vols. Tokyo: Sophia University Press, 1999-2000.

Evennett, H. Outram. The Spirit of the Counter-Reformation: The Birkbeck Lectures in Ecclesiastical History Given in the University of Cambridge in May 1951. Edited by John Bossy. Cambridge: Cambridge University Press, 1968.

Fabre, Pierre Antoine. "Dossiers bibliographiques: Histoire des arts visuels." Revue de synthèse, 4th series, nos. 2-3 (April-September 1999): 462-68. 
Fabre, Pierre Antoine. Ignace de Loyola, le lieu de l'image: Le problème de la composition de lieu dans les pratiques spirituelles et artistiques jésuites de la seconde moitié duXVI siècle. Paris: J. Vrin, 1992.

Fabre, Pierre Antoine, and Antonella Romano. "Présentation." Revue de synthèse, 4th series, nos. 2-3 (April-September 1999): 247-6o.

Fabre, Pierre Antoine, and Flavio Rurale, eds. The Acquaviva Project: Claudio Acquaviva's Generalate (1581-1615) and the Emergence of Modern Catholicism. Chestnut Hill, MA: Institute of Jesuit Sources, Boston College, 2017.

Falkenburg, Reindert, Walter S. Melion, and Todd Richardson, eds. Image \& Imagination of the Religious Self in Late Medieval and Early Modern Europe. Turnhout: Brepols, 2008.

Feo, Vittorio de, and Valentino Martinelli, eds. Andrea Pozzo. Milan: Electa, 1996.

Fernández, Victor M., Jorge de Torres, Andreu Martínez d'Alòs-Moner, and Carlos Cañete. The Archaeology of the Jesuit Missions in Ethiopia (1557-1632). Jesuit Studies 10. Leiden and Boston: Brill, 2017.

Fernie, Eric, ed. Art History and Its Methods: A Critical Anthology. London: Phaidon Press, 1995 .

Fiorani, Luigi, and Adriano Prosperi, eds. Storia d'Italia: Annali 16; Roma, città del papa. Turin: Einaudi, 2000.

Fleming, Alison C., ed. “Jesuit Visual Culture." Journal of Jesuit Studies 6, no. 2 (Spring 2019).

Fleming, David L., s.J., ed. Draw Me into Your Friendship: A Literal Translation and a Contemporary Reading of the Spiritual Exercises. Studies on Jesuit Topics 17. St. Louis, MO: Institute of Jesuit Sources, 1996.

Flood, Finbarr B. Objects of Translation: Material Culture and Medieval "Hindu-Muslim" Encounter. Princeton: Princeton University Press, 2009.

Frois, Luís. Lettera annua del Giappone dell'anno 1596. Rome: Luigi Zanetti, 1599.

Frois, Luís. Lettera del Giappone degli anni 1591 et 1592. Rome: Luigi Zanetti, 1595.

Fuchs, Barbara. Mimesis and Empire: The New World, Islam, and European Identities. Cambridge: Cambridge University Press, 2001.

Fullam, Lisa. "Juana, S.J.: The Past (and Future?) Status of Women in the Society of Jesus." Studies in the Spirituality of Jesuits 31, no. 5 (November 1999): 1-39.

Fumaroli, Marc. L'âge de l'éloquence: Rhétorique et "res literaria" de la Renaissance au seuil de l'époque classique. Geneva: Librairie Droz, 2009.

Fumaroli, Marc. L'école du silence: Le sentiment des images au XVII siècle. Paris: Flammarion, 1998.

Gadamer, Hans-Georg. Hermeneutik I. Wahrheit und Methode: Grundzüge einer philosophischen Hermeneutik. Hans-Georg Gadamer Gesammelte Werke 1. Rev. ed. Tübingen: Mohr Siebeck, 2010.

Gadamer, Hans-Georg. Truth and Method. Translated by Joel Weinsheimer and Donald G. Marshall. Rev. ed. New York: Continuum, 2002 [1989]. 
Gailhabaud, Jules. Denkmäler der Baukunst. Edited by Ludwig Lohde. 4 Vols. Hamburg: J.A. Meissner, $185^{2}$.

Gailhabaud, Jules. Monuments anciens et modernes: Collection formant une histoire de l'architecture des differents peuples à toutes les époques. 4 Vols. Paris: F. Didot, 1846-5o.

Ganss, George E., s.J., ed. and trans. The Spiritual Exercises of Saint Ignatius: A Translation and a Commentary. Chicago and St. Louis, MO: Loyola Press and Institute of Jesuit Sources, 1992.

Giard, Luce, and Louis de Vaucelles, s.J., eds. Les jésuites à l'âge baroque 1540-1640. Grenoble: Jérôme Millon, 1996.

Gilmont, Jean-François, s.J. Les écrits spirituels des premiers jésuites: Inventaire commenté. Studia ad Historiam Societatis Iesu 3. Rome: Institutum Historicum Societatis Iesu, 1961.

Girard, René. The Scapegoat. Translated by Yvonne Freccero. Baltimore: Johns Hopkins University Press, 1989 [1986].

Girard, René. Violence and the Sacred. Translated by Patrick Gregory. Baltimore: Johns Hopkins University Press, 1979 [1977].

Gleason, Robert W., s.J., ed. Contemporary Spirituality. New York: Macmillan, 1968.

Godwin, Joscelyn. Athanasius Kircher's Theatre of the World: His Life, Work, and the Search for Knowledge. Rochester, NY: Inner Traditions, 2009.

Goethem, Herman Van, ed. Antwerpen en de Jezuïeten, 1562-2002. Antwerp: UfSIA, 2002.

Goff, Jacques Le, and Pierre Nora, eds. Faire de l'histoire. 3 Vols. Paris: Gallimard, 1974.

Gomes, Paulo Varela. Whitewash, Red Stone: A History of Church Architecture in Goa. New Delhi: Yoda Press, 2011.

Gómez, Pedro. Lettera annua del Giappone dal marzo del 1593 fino al marzo del 1594. Rome: Luigi Zanetti, 1597.

Gossman, Lionel. Basel in the Age of Burckhardt: A Study in Unseasonable Ideas. Chicago: University of Chicago Press, 2000.

Gotor, Miguel. I beati del papa: Santità, Inquisizione e obbedienza in età moderna. Biblioteca della "Rivista di storia e letteratura religiosa" 16. Florence: Leo S. Olschki, 2002.

Göttler, Christine, and Mia M. Mochizuki, eds. The Nomadic Object: The Challenge of World for Early Modern Religious Art. Intersections: Interdisciplinary Studies in Early Modern Culture 53. Leiden and Boston: Brill, 2018.

Göttler, Christine, Bart Ramakers, and Joanna Woodall, eds. Trading Values in Early Modern Antwerp. Nederlands Kunsthistorisch Jaarboek 64. Leiden and Boston: Brill, 2014.

Gramatowski, Wiktor, s.J. Jesuit Glossary: Guide to Understanding the Documents. Translated by Camilla Russell. Rev. ed. Rome: Archivum Romanum Societatis Iesu, 2013. http://www.sjweb.info/arsi/documents/glossary.pdf (accessed March 15, 2021). 
Greyerz, Kaspar von, ed. Religion and Society in Early Modern Europe 1500-1800. London: German Historical Institute and George Allen \& Unwin, 1984.

Grote, Andreas, ed. Macrocosmos in Microcosmo: Die Welt in der Stube; Zur Geschichte des Sammelns 1450 bis 1800. Opladen: Leske und Budrich, 1994.

Guibert, Joseph de, s.J. The Jesuits: Their Spiritual Doctrine and Practice; A Historical Study. Edited by George E. Ganss, s.J., and translated by William J. Young, s.J. St. Louis, MO: Institute of Jesuit Sources, 1986 [1964].

Guillaume, Jean, ed. L'église dans l'architecture de la Renaissance: Actes du colloque tenu à Tours du 28 au 31 mai 199o. Paris: Picard, 1995.

Gumppenberg, Wilhelm, s.J. Atlas Marianus. Munich: Johann Jaecklin, 1672.

Guo, Nanyan, ed. Kirishitan ga hiraita Nihongo bungaku: Tagengo tabunka kouryū no engen. Tokyo: Akashi Shoten, 2017.

Gutiérrez, Fernando García, s.J. "Iconografía de San Francisco Javier en Oriente." Archivum historicum Societatis Iesu 71 (July-December 2002): 279-301.

Hadot, Pierre. Philosophy as a Way of Life: Spiritual Exercises from Socrates to Foucault. Edited by Arnold I. Davidson and translated by Michael Chase. Oxford: Blackwell, 1995 .

Hall, Marcia B., and Tracy E. Cooper, eds. The Sensuous in the Counter-Reformation Church. Cambridge: Cambridge University Press, 2013.

Harrington, Ann M. Japan's Hidden Christians. Chicago: Loyola University Press, 1993. Haub, Rita, and Julius Oswald, s.J., eds. Franz Xaver: Patron der Missionen; Festschrift zum 45o. Todestag. Jesuitica 4. Regensburg: Verlag Schnell \& Steiner, 2002.

Heal, Bridget. The Cult of the Virgin Mary in Early Modern Germany: Protestant and Catholic Piety, 1500-1648. Cambridge: Cambridge University Press, 2014.

Heal, Bridget, and Joseph Koerner, eds. "Art and Religious Reform in Early Modern Europe." Art History, Special Issue on the 5ooth Anniversary of the Lutheran Reformation, 4O, no. 2 (April 2017). https://onlinelibrary.wiley.com/toc/14678365/ 2017/40/2 (accessed March 15, 2021).

Heidegger, Martin. Gesamtausgabe: I. Abteilung; Veröffentlichte Schriften 1910-1976; Vol. 7 Vorträge und Aufsätze. Edited by Friedrich-Wilhelm von Herrmann. Frankfurt am Main: Verlag Vittorio Klostermann, 2000.

Heidegger, Martin. The Question concerning Technology and Other Essays. Translated by William Lovitt. New York: Harper \& Row, 1977.

Heldman, Marilyn, Stuart C. Munro-Hay, and Roderick Grierson, eds. African Zion: The Sacred Art of Ethiopia. Exhibition catalog. Baltimore: Walters Art Gallery, 1993.

Henriques, Ana de Castro, ed. Portugal and the World in the 16th and 17th Centuries. Exhibition catalog. Lisbon: Museu Nacional de Arte Antiga, 20o9.

Henriques, António Meira Marques. "A devoção jesuíta a Nossa Senhora de S. Lucas: Estudo de dois quadros do Museu de São Roque." Brotéria 176 (February 2013): $15^{2-6 o .}$ 
Henriques, António Meira Marques. São Francisco Xavier: Vida e lenda/Saint Francis Xavier; Life and Legend. Lisbon: Museu de São Roque/Santa Casa da Misericórdia de Lisboa, 2006.

Herbermann, Charles G. et al., eds. The Catholic Encyclopedia. 15 Vols. New York: Robert Appleton Co., 1907-14.

Hernán, Enrique García, and María del Pilar Ryan, eds. Francisco de Borja y su tiempo: Política, religión y cultura en la edad moderna. Valencia and Rome: Albatros Ediciones and Institutum Historicum Societatis Iesu, 2011.

Hinde, John R. Jacob Burckhardt and the Crisis of Modernity. Montreal: McGill-Queen's University Press, 2000.

Hirakawa, Kayo, ed. Sacred and Profane in Early Modern Art. Kyoto Studies in Art History 1. Kyoto: Kyoto University, 2016.

Hoffmann, Hermann. "Der Breslauer Mathematiker Theodor Moretus S.J. (1601-1667)." Schlesische Gesellschaft für Vaterländische Cultur 107 (1934): 118-55.

Homann, Frederick A., s.J., ed. and trans. Jerome Nadal, S.J.: Annotations and Meditations on the Gospels. 3 Vols. Philadelphia: St. Joseph's University Press, 2003-7.

Horn, Andrew. Andrea Pozzo and the Religious Theatre of the Seventeenth Century. Early Modern Catholicism and the Visual Arts Series 18. Philadelphia: St. Joseph's University Press, 2019.

Hsia, Ronnie Po-chia, ed. The Cambridge History of Christianity: Vol. 6; Reform and Expansion 1500-1660. Cambridge: Cambridge University Press, 2007.

Hugo, Herman. Pia desideria, emblematis, elegiis et affectibus SS. Patrum illustrata. Antwerp: Boetius Bolswert and Hendrik Aertssens, 1624.

Ignatius of Loyola. The Constitutions of the Society of Jesus. Edited by George Ganss, S.J. St. Louis, MO: Institute of Jesuit Sources, 1970.

Ignatius of Loyola. Exercitia spiritualia Sancti Ignatii de Loyola et eorumque directoria. 2 Vols. Rev. ed. Rome: Monumenta Historica Societatis Iesu, 1955.

Ignatius of Loyola. Geestelycke oeffeninghen vanden H. vader Ignatius van Loyola. Antwerp: Michiel Cnobbaert, 1673 .

Ignatius of Loyola. Letters and Instructions. Edited and translated by Martin E. Palmer, S.J., John W. Padberg, S.J., and John L. McCarthy, S.J. St. Louis, MO: Institute of Jesuit Sources, 2006.

Ignatius of Loyola. Monumenta Ignatiana ex autographis vel ex antiquioribus exemplis collecta: Monumenta Constitutionum praevia. 4 Vols. Rome: Monumenta Historica Societatis Iesu, 1934-38, 1948.

Ignatius of Loyola. Spiritual Exercises. Edited and translated by Joseph A. Munitz, s.J., and Philip Endean, s.J. Rev. ed. London: Penguin, 2004.

Ignatius of Loyola. Sancti Ignatii de Loyola Societatis Iesu fundatoris epistolae et instructiones. 12 Vols. Rome: Monumenta Historica Societatis Iesu, 1964-68 [19o3-11]. 
Ignatius of Loyola. Scripta de Sancto Ignatio de Loyola Societatis Iesu fondatore. 3 Vols.

Rev. ed. Rome: Monumenta Historica Societatis Iesu, 1943-6o.

Ignatius of Loyola. The Spiritual Exercises and Selected Works. Edited and translated by

George E. Ganss, s.J. Classics of Western Spirituality. New York: Paulist Press, 1991.

Illustrated Catalogue of Tokyo National Museum: Kirishitan Objects; Christian Relics in Japan 16th-19th Century. Rev. ed. Tokyo: Tokyo National Museum, 2001.

Imhof, Paul, s.J., ed. Ignatius of Loyola. Translated by Rosaleen Ockenden. London: Collins, 1979 .

Imorde, Joseph, Fritz Neumeyer, and Tristan Weddigen, eds. Barocke Inszenierung: Akten des Internationalen Forschungscolloquiums an der Technischen Universität Berlin 20.-22. June 1996. Emsdetten: Edition Imorde, 1999.

Insolera, Lydia Salviucci. "Le illustrazioni per gli Esercizi spirituali intorno al 16oo." Archivum historicum Societatis Iesu 6o (1991): 161-217.

Insolera, Lydia Salviucci. L'imago primi saeculi (1640) e il significato dell'immagine allegoria nella Compagnia di Gesù: Genesi e fortuna del libro. Rome: Editrice Pontificia Università Gregoriana, 2004.

Insolera, Manuel, and Lydia Salviucci Insolera. La spiritualité en images aux Pays-Bas Méridionaux dans les livres imprimés des XVI et XVII e siècles conservés à la Bibliotheca Wittockiana. Miscellanea Neerlandica 13. Exhibition catalog. Leuven: Peeters, 1996.

Instituto de Estudios Iconográficos, ed.Lecturas de historia de arte:Vol. 4.Vitoria-Gasteiz: Instituto de Estudios Iconográficos Ephialte, 1994.

Iparraguirre, Ignacio, S.J., ed. Directoria Exercitiorum spiritualium (1540-1599). Monumenta Historica Societatis Iesu 76. Rome: Monumenta Historica Societatis Iesu, 1955 .

Iparraguirre, Ignacio, s.J., ed. Historia de la práctica de los Ejercicios espirituales de San Ignacio de Loyola. 3 Vols. Bilbao and Rome: El Mensajero del Corazón de Jesús and Institutum Historicum Societatis Iesu, 1946-73.

Irwin, David, ed. Winckelmann: Writings on Art. London: Phaidon Press, 1972.

Jennes, Jozef, c.I.C.M. Invloed der vlaamsche prentkunst in Indië, China en Japan tijdens de XVI e en XVII eeuw. Leuven: Davidfonds, 1943.

Jones, Pamela M., Barbara Wisch, and Simon Ditchfield, eds. A Companion to Early Modern Rome 1492-1692. Leiden and Boston: Brill, 2019.

Jones, Pamela M., and Thomas Worcester, s.J., eds. From Rome to Eternity: Catholicism and the Arts in Italy, c.1550-1650. Leiden and Boston: Brill, 2002.

Joselit, David. After Art. Princeton: Princeton University Press, 2013.

Journal ofJesuit Studies. Leiden and Boston: Brill, 2014-present. https://brill.com/view/ journals/jjs/jjs-overview.xml (accessed March 15, 2021).

Kaegi, Werner. Jacob Burckhardt: Eine Biographie. 7 Vols. Basel: Benno Schwabe, 1947-77. 
Kamba, Nobuyuki. “Kirishitan kaiga no seisaku gijutsu to zairyō (1): Ōsaka-fu Ibaraki-shi ni oite hakken sareta sakuhin." Tōkyō Kokuritsu Hakubutsukan kiyō 42 (2006): 5-122.

Kamba, Nobuyuki. "Kokuritsu rekishi minzoku hakubutsukan tokutei kenkyū nanban kankei shiryōhan niyoru kōbe shiritsu hakubutsukanzō 'Sei furansisko sabieruzō' no chōsa nikansuru gaiyō." Kōbe shiritsu hakubutsukan kenkyū kiyō 16 (2000): 1-15.

Kaplan, Benjamin J., Marybeth Carlson, and Laura Cruz, eds. Boundaries and Their Meanings in the History of the Netherlands. Leiden and Boston: Brill, 2009.

Kataoka, Yakichi. Fumie: Kinkyō no rekishi. NHK Bukkusu 9o. 2nd ed. Tokyo: Nihon Hōsō Shuppan Kyōkai, 1977.

Kaufmann, Thomas DaCosta. Toward a Geography of Art. Chicago: University of Chicago Press, 2004.

Keener, Frederick M., ed. Virgil's Aeneid: Translated by John Dryden. London: Penguin, 1997.

Kertzer, David I. The Pope and Mussolini: The Secret History of Pius XI and the Rise of Fascism in Europe. New York: Random House, 2014.

Kircher, Athanasius. Ars magna lucis et umbrae. Rome: Hermann Scheus and Ludovico Grignani, 1646.

Kley, Dale K. Van. Reform Catholicism and the International Suppression of the Jesuits in Enlightenment Europe. New Haven: Yale University Press, 2018.

Kobayashi-Sato, Yoriko, and Mia M. Mochizuki. Gurōbaru jidai no yoake: Nichiō bunka no deai, kosaku to sono zanshō 1541-1853. Kyoto: Koyo Shobo, 2017.

Kokushi Daijiten. 17 Vols. Tokyo: Yoshikawa Kōbunkan, 1979-97.

König-Nordhoff, Ursula. Ignatius von Loyola: Studien zur Entwicklung einer neuen Heiligen-Ikonographie im Rahmen einer Kanonisationskampagne um 1600 . Berlin: Gebr. Mann Verlag, 1982.

Körner, Hans. Der früheste deutsche Einblattholzschnitt. Mittenwald: Mäander Kunstverlag, 1979.

Koschorke, Klaus, Frieder Ludwig, and Mariano Delgado, eds. A History of Christianity in Asia, Africa, and Latin America, 1450-1990: A Documentary Sourcebook. Grand Rapids, MI: William B. Eerdmans, 2007.

Kubler, George. Portuguese Plain Architecture: Between Spices and Diamonds, 1521-1706. Middletown, CT: Wesleyan University Press, 1972.

Kupfer, Marcia, ed. The Passion Story: From Visual Representation to Social Drama. University Park, PA: Pennsylvania State University Press, 2008.

Lacan, Jacques. The Seminar of Jacques Lacan: Book XI; The Four Fundamental Concepts of Psychoanalysis. Edited by Jacques-Alain Miller and translated by Alan Sheridan. New York: W.W. Norton \& Company, 1998 [1981].

Lang, Susanne. Bilder zur Mission: Die jesuitische Literatur und ihre Illustration. Petersberg: Michael Imhof Verlag, 2012.

Latour, Bruno. Reassembling the Social: An Introduction to Actor-Network-Theory. Oxford: Oxford University Press, 2005. 
Laures, Johannes, s.J. Kirishitan Bunko: A Manual of Books and Documents on the Early Christian Mission in Japan. Rev. ed. Tokyo: Sophia University Press, 1957.

Lea, Joseph P., ed. Jerome Nadal, S.J.: Annotations and Meditations on the Gospels; Cumulative Index. Philadelphia: St. Joseph's University Press, 2014.

Lehmann, Ann-Sophie, Frits Scholten, and H. Perry Chapman, eds. Meaning in Materials, 1400-1800. Nederlands Kunsthistorisch Jaarboek 62. Leiden and Boston: Brill, 2012.

Leibsohn, Dana, and Jeanette Favrot Peterson, eds. Seeing across Cultures in the Early Modern Period. Farnham: Ashgate, 2012.

Levy, Evonne. "Architecture and Religion in Seventeenth-Century Rome." Studiolo 2 (2003): 219-53.

Levy, Evonne. Baroque and the Political Language of Formalism (1845-1945): Burckhardt, Wölfflin, Gurlitt, Brinckmann, Sedlmayr. Basel: Schwabe Verlag, 2015.

Levy, Evonne. "Early Modern Jesuit Arts and Jesuit Visual Culture." Journal of Jesuit Studies 1, no. 1 (2014): 66-87.

Levy, Evonne. "The Institutional Memory of the Roman Gesù: Plans for Renovation in the 1670 os by Carlo Fontana, Pietro da Cortona and Luca Berrettini." Römisches Jahrbuch der Bibliotheca Hertziana 33 (1999-2000): 373-426.

Levy, Evonne. Propaganda and the Jesuit Baroque. Berkeley: University of California Press, 2004.

Lippiello, Tiziana, and Roman Malek, eds. "Scholar from the West": Giulio Aleni S.J. (1582-1649) and the Dialogue between Christianity and China. Nettetal: Steyler Verlag, 1997.

Lombaerde, Piet, ed. Innovation and Experience in the Early Baroque in the Southern Netherlands: The Case of the Jesuit Church in Antwerp. Turnhout: Brepols, 2008.

Lucas, Thomas M., s.J. Landmarking: City, Church, and Jesuit Urban Strategy. Chicago: Loyola Press, 1997.

Lucas, Thomas M., s.J., ed. Saint, Site, and Sacred Strategy: Ignatius, Rome, and Jesuit Urbanism. Exhibition catalog. Vatican City: Biblioteca Apostolica Vaticana, 1990.

Lucca, Denis De. Jesuits and Fortifications: The Contributions of the Jesuits to Military Architecture in the Baroque Era. Leiden and Boston: Brill, 2012.

Lukács, László, S.J., ed. Ratio atque institutio studiorum Societatis Iesu (1586, 1591, 1599). Rome: Institutum Historicum Societatis Iesu, 1986.

Ludolph of Saxony. Vita Christi. Cologne and Strasbourg: Arnold ter Hoernen, [c.1472] and Heinrich Eggestein, 1474.

Luhmann, Niklas. Art as a Social System. Stanford: Stanford University Press, 2000.

Mâle, Émile. L'art religieux de la fin du XVI siècle, du XVII siècle et du XVIII ${ }^{e}$ siècle: Étude sur l'iconographie après le Concile de Trente, Italie-France-Espagne-Flandres. Rev. ed. Paris: Librairie Armand Colin, 1951. 
Manning, John, and Marc Van Vaeck, eds. The Jesuits and the Emblem Tradition: Selected Papers of the Leuven International Emblem Conference 18-23 August 1996. Imago Figurata Studies 1A. Turnhout: Brepols, 1999.

Marcolini, Egidio, s.J. Mater divinae gratiae: La Madonna del noviziato nella provincia Veneto-Milanese della Compagnia di Gesù. Padua: Tipografia Antoniana, 1941.

Marin, Louis. On Representation. Translated by Catherine Porter. Palo Alto: Stanford University Press, 2001.

Marlowe, Christopher. Doctor Faustus and Other Plays. Edited by David Bevington and Eric Rasmussen. Oxford: Oxford University Press, 1995.

Martins, Fausto Sanches. "Notícia sobre o autor e a data do quadro da 'Virgem S. Lucas' do Colégio de Coimbra." Lusitana Sacra, 2nd series, 5 (1993): 121-35.

Maryks, Robert A., ed. Brill Research Perspectives in Jesuit Studies. Leiden and Boston: Brill, 2018-present. https://brill.com/view/serial/RPJSS (accessed March 15, 2021).

Maryks, Robert A., ed. A Companion to Ignatius of Loyola. Brill's Companions to the Christian Tradition: A Series of Handbooks and Reference Works on the Intellectual and Religious Life of Europe, 500-180o, 52. Leiden and Boston: Brill, 2014.

Maryks, Robert A., ed. A Companion to Jesuit Mysticism. Brill's Companions to the Christian Tradition: A Series of Handbooks and Reference Works on the Intellectual and Religious Life of Europe, 500-180o, 78. Leiden and Boston: Brill, 2017.

Maryks, Robert A. "From the IJssel Valley to Paris and Rome via Montserrat." Church History and Religious Culture 101, no. 1 (February 2021): 33-6o.

Maryks, Robert A., ed. Jesuit Historiography Online. Leiden and Boston: Brill, 2016present. https://referenceworks.brillonline.com/browse/jesuit-historiography-online (accessed March 15, 2021).

Maryks, Robert A., ed. "Jesuit Studies." Leiden and Boston: Brill, 2013-present. https:// brill.com/view/serial/JS (accessed March 15, 2021).

Massing, Jean Michel. “Jerome Nadal's Evangelicae historiae imagines and the Birth of Global Imagery." Journal of the Warburg and Courtauld Institutes 80 (2017): 161-220.

Mauquoy-Hendrickx, Marie. Les estampes des Wierix. 4 Vols. Brussels: Bibliothèque Royale Albert I ${ }^{\mathrm{er}}$, 1978-83.

Mauquoy-Hendrickx, Marie. "Les Wierix illustrateurs de la Bible dite de Natalis." Quaerendo 6 (1976): 28-63.

McCall, John E. "Early Jesuit Art in the Far East." Artibus Asiae 10 (1947): 121-37, 216-33, 283-301; 11 (1948): 45-69; 17 (1954): 39-54.

McCoog, Thomas, s.J., ed. Ite inflammate omnia: Selected Historical Papers from Conferences Held at Loyola and Rome in 2006. Rome: Institutum Historicum Societatis Iesu, 2010.

McCoog, Thomas, s.J., ed. With Eyes and Ears Open: The Role of Visitors in the Society of Jesus. Jesuit Studies 21. Leiden and Boston: Brill, 2019. 
McNaspy, Clement J., S.J. “Art in Jesuit Life." Studies in the Spirituality of the Jesuits 5, no. 3 (April 1973): 93-111.

Meijer, Bert W., ed. Northern Landscapes on Roman Walls: The Frescoes of Matthijs and Paul Bril. Exhibition catalog. Florence: Centro Di della Edifimi, 2003.

Meissner, William W., s.J. To the Greater Glory: A Psychological Study of Ignatian Spirituality. Milwaukee, WI: Marquette University Press, 2013 [1999].

Melion, Walter S. The Meditative Art: Studies in the Northern Devotional Print, 1550-1625. Early Modern Catholicism and the Visual Arts Series 1. Philadelphia: St. Joseph's University Press, 2009 .

Melion, Walter S., and Lee Palmer Wandel, eds. Early Modern Eyes. Intersections: Interdisciplinary Studies in Early Modern Culture 13. Leiden and Boston: Brill, 2009.

Melion, Walter S., Elizabeth Carson Pastan, and Lee Palmer Wandel, eds. Quid est sacramentum? Visual Presentation of Sacred Mysteries in Early Modern Europe, 14001700. Intersections: Interdisciplinary Studies in Early Modern Culture 65. Leiden and Boston: Brill, 2019.

Melloni, Javier, S.J. The Exercises of St. Ignatius and Traditions of the East. Translated by Michael Kirwan, s.J. Leominster and New Malden: Gracewing and Inigo Enterprises, 2013.

Mercier, Jacques. "Les sources iconographiques occidentales du cycle de la vie du Christ dans la peinture éthiopienne du dix-huitième siècle." Journal Asiatique 287, no. 2 (1999): 375-94.

Mochizuki, Mia M. “The Dutch Text Painting.” Word and Image 23 (2007): 72-88.

Mochizuki, Mia M. "A Global Eye: The Perception of Place in a Pair of Tokugawa World Map Screens." Japan Review 29 (2016): 69-119.

Mochizuki, Mia M. "Global na me: Tokugawa-ke Bankoku Ezu byobu ni okeru basyo no ninshiki." Bïutsushi Ronsō: Tōkyō Daigaku Bungakubu Bijutsushi Kenkyūshitsu $3^{2}$ (March 2016): 100-52.

Mochizuki, Mia M. The Netherlandish Image after Iconoclasm, 1566-1672: Material Religion in the Dutch Golden Age. Aldershot: Ashgate, 2008.

Moisy, Pierre. Les églises des jésuites de l'ancienne assistance de France. Bibliotheca Instituti Historici Societatis Iesu 12. 2 Vols. Rome: Institutum Historicum Societatis Iesu, 1958.

Moisy, Pierre. "Martellange, Derand et le conflit du baroque." Bulletin monumental 11o, no. 3 (1952): 237-61.

Moisy, Pierre. "Le recueil des plans jésuites de Quimper: Nouvelle étude." Bulletin de la Société de l'Histoire de l'Art Français (1950): 70-84.

Molina, J. Michelle. To Overcome Oneself: The Jesuit Ethic and Spirit of Global Expansion, 1520-1767. Berkeley: University of California Press, 2013.

Montenay, Georgette de. Emblemes ou devises chretiennes. Lyon: Jean Marcorelle, $[c .1567-71]$. 
Monumenta Xaveriana ex autographis vel ex antiquioribus exemplis collecta. 2 Vols. Madrid: Typis Augustinus Avrial and Gabrielis Lopez del Horno, 1899-1912.

Moran,Joseph F. The Japanese and the Jesuits: Alessandro Valignano in Sixteenth-Century Japan. London: Routledge, 1993.

Moretus, Theodor. Principatus incomparabilis primi filii hominis, Messiae, et primae parentis Matris Virginis in conceptione illius immaculata exhibitus. Cologne: Johann Busäus, 1671.

Mormando, Franco, ed. Saints and Sinners: Caravaggio and the Baroque Image. Exhibition catalog. Chestnut Hill, MA: McMullen Museum of Art, Boston College, 1999.

Münch, Birgit Ulrike. Geteiltes Leid: Die Passion Christi in Bildern und Texten der Konfessionalisierung. Regensburg: Schnell \& Steiner, 2009.

Nadal, Jerónimo. Adnotationes et meditationes in Evangelia quae in sacrosancto Missae sacrificio toto anno leguntur. Antwerp: Martin II Nuyts, 1595.

Nadal, Jerónimo. Epistolae P. Hieronumi Nadal Societatis Iesu, ab anno 1546 ad 1577.5 Vols. Madrid and Rome: Typis Gabrielis Lopez del Horno and Monumenta Historica Societatis Iesu, 1898-1962.

Nadal, Jerónimo. P. Hieronymi Nadal orationis obeservationes. Edited by Michael [Miguel] Nicolau, S.J. Rome: Institutum Historicum Societatis Iesu, 1964.

Nakajyo, Tadashi, and Kenichi Tanigawa. Kakure Kirishitan no seiga. Tokyo: Shōgakkan, 1999.

Nancy, Jean-Luc. Portrait. Translated by Sarah Clift and Simon Sparks. New York: Fordham University Press, 2018.

Nelis, Jan, Anne Morelli, and Danny Praet, eds. Catholicism and Fascism in Europe 19181945. Hildesheim: Georg Olms Verlag, 2015.

Nelson, Robert S., and Richard Schiff, eds. Critical Terms for Art History. 2nd ed. Chicago: University of Chicago Press, 2003.

Nicolas, Antonio T de. Powers of Imagining: Ignatius de Loyola; A Philosophical Hermeneutic of Imagining through the Collected Works of Ignatius de Loyola with a Translation of These Works. Albany, NY: State University of New York Press, 1986.

Nicolau, Miguel, s.J. Jerónimo Nadal S.I. (1507-1580): Sus obras y doctrinas espirituales. Madrid: Consejo Superior de Investigaciones Científicas, 1949.

Nicolau, Miguel, S.J. Pláticas espirituales del P. Jeronimo Nadal, S.I. en Coimbra, 1567. Granada: Facultad Teológica de la Compañía Jesús, 1945.

Niemetz, Michael. Antijesuitische Bildpublizistick in der Frühen Neuzeit: Geschichte, Ikonographie und Ikonologie. Jesuitica: Quellen und Studien zu Geschichte, Kunst, und Literatur der Gesellschaft Jesu im deutschsprachigen Raum 13. Regensburg: Schnell \& Steiner, 2008.

Nishimura, Tei. Namban-bijutsu. Tokyo: Kodansha, 1958.

Nishimura, Tei. Nihon shoki yōga no kenkyū. Osaka: Zenkoku Shobō, 1945. 
North, Michael, ed. Artistic and Cultural Exchanges between Europe and Asia, 1400-1900: Rethinking Markets, Workshops, and Collections. Farnham: Ashgate, 2010.

O'Malley, John W., s.J., ed. Art, Controversy, and the Jesuits: The Imago primi saeculi (1640). Early Modern Catholicism and the Visual Arts Series 12. Philadelphia: St. Joseph's University Press, 2015 .

O'Malley, John W., s.J., ed. Constructing a Saint through Images: The 1609 Illustrated Biography of Ignatius of Loyola. Philadelphia: St. Joseph's University Press, 2008.

O’Malley, John W., s.J. The First Jesuits. Cambridge, MA: Harvard University Press, 1993.

O'Malley, John W., s.J. "Past, Present, and Future of Jesuit Studies: Historiographical Thoughts." Journal of Jesuit Studies 5, no. 4 (Winter 2018): 501-10.

O'Malley, John W., s.J. Religious Culture in the Sixteenth Century. Aldershot: Ashgate, 1993.

O’Malley, John W., s.J. Saints or Devils Incarnate? Studies in Jesuit History. Jesuit Studies 1. Leiden and Boston: Brill, 2013.

O'Malley, John W., s.J. “To Travel to Any Part of the World: Jerónimo Nadal and the Jesuit Vocation." Studies in the Spirituality of Jesuits 16, no. 2 (March 1984): iv, 1-20.

O'Malley, John W., s.J., and Gauvin Alexander Bailey, eds. The Jesuits and the Arts, 15401773. Philadelphia: Saint Joseph's University Press, 2005.

O'Malley, John W., s.J., Gauvin Alexander Bailey, Steven J. Harris, and T. Frank Kennedy, s.J., eds. The Jesuits: Cultures, Sciences, and the Arts, 1540-1773. Toronto: University of Toronto Press, 1999.

O'Malley, John W., s.J., Gauvin Alexander Bailey, Steven J. Harris, and T. Frank Kennedy, s.J., eds. The Jesuits II: Cultures, Sciences, and the Arts, 1540-1773. Toronto: University of Toronto Press, 2006.

O’Malley, John W., s.J., John W. Padberg, s.J., and Vincent T. O'Keefe, s.J., eds. Jesuit Spirituality: A Now and Future Resource. Chicago: Loyola Press, 1990.

O'Reilly, Terence. From Ignatius Loyola to John of the Cross: Spirituality and Literature in Sixteenth-Century Spain. Aldershot: Variorum, 1995.

O'Reilly, Terence. The Spiritual Exercises of Saint Ignatius of Loyola: Contexts, Sources, Reception. Jesuit Studies 31. Leiden and Boston: Brill, 2020.

Ojeda, Almerindo E., and Alfonso Ortiz Crespo, eds. De Augsburgo a Quito: Fuentes grabadas del arte jesuita quiteño del siglo XVIII. Exhibition catalog. Quito:Fundación Iglesia de la Compañia de Jesús, 2015.

Oliveira, Maria Helena, Teresa Freitas Morna, Maria Jõao Ferreira, and Maria Madalena Requixa, eds. Museum of São Roque. Translated by Thomas E. Fisher. Lisbon: Santa Casa da Misericórdia de Lisboa, 2008.

Orenstein, Nadine M. Hendrick Hondius and the Business of Prints in Seventeenth-Century Holland. Studies in Print and Printmaking 1. Rotterdam: Sound \& Vision, 1996.

Osano, Shigetoshi, and Milosz Wozny, eds. Between East and West: Reproductions in Art. Proceedings of the 2013 CIHA Colloquium in Naruto, Japan, Tokyo, January 15-18, 2013. Krakow: Institute for Art Historical Research/IRSA, 2014. 
Osswald, Maria Cristina. "The Iconography and Cult of Francis Xavier, 1552-1640." Archivum historicum Societatis Iesu 71 (July-December 2002): 259-77.

Osswald, Maria Cristina. Written in Stone:Jesuit Buildings in Goa and Their Artistic and Architectural Features. Saligao: 1556 and Golden Heart Emporium Book Shop, 2013.

Ostrow, Steven F. Art and Spirituality in Counter-Reformation Rome: The Sistine and Pauline Chapels in S. Maria Maggiore. Cambridge: Cambridge University Press, 1996.

Oy-Marra, Elisabeth, and Volker R. Remmert, eds. Le monde est une peinture:Jesuitische Identität und die Rolle der Bilder. Berlin: Akademie Verlag, 2011.

Padberg, John W., s.J., ed. The Constitutions of the Society of Jesus and Their Complementary Norms. St. Louis, MO: Institute of Jesuit Sources, 1996.

Padberg, John W., S.J., ed. Jesuit Life and Mission Today: The Decrees and Accompanying Documents of the 31st-35th General Congregations of the Society of Jesus. St. Louis, MO: Institute of Jesuit Sources, 2009.

Padberg, John W., s.J., Martin D. O'Keefe, s.J., and John L. McCarthy, s.J., eds. For Matters of Greater Moment: The First Thirty Jesuit General Congregations; A Brief History and a Translation of the Decrees. St. Louis, MO: Institute of Jesuit Sources, 1994.

Palmer, Martin E., s.J., ed. and trans. On Giving the Spiritual Exercises: The Early Jesuit Manuscript Directories and the Official Directory of 1599. Jesuit Primary Sources in English Translation 14. St. Louis, MO: Institute of Jesuit Sources, 1996.

Paluzzi, Carlo Galassi. Storia segreta dello stile dei gesuiti. Rome: Francesco Mondini Editore, 1951.

Panofsky, Erwin. Early Netherlandish Painting: Its Origins and Character. 2 Vols. Cambridge, MA: Harvard University Press, 1947.

Panofsky, Erwin. Meaning in the Visual Arts. Chicago: University of Chicago Press, 1982 [1955].

Panofsky, Erwin. Perspective as Symbolic Form. Translated by Christopher S. Wood. New York: Zone Books, 2012 [1991].

Panofsky, Erwin. Studies in Iconology: Humanistic Themes in the Art of the Renaissance. Rev. ed. London: Routledge, 2019.

Panvinio, Onofrio. De praecipius urbis Romae, sanctioribusque, basilicis, quas septem ecclesias vulgo vocant. Rome: Heirs of Antonio Blado, 1570.

Papa, Giovanni. Le cause di canonizzazione nel primo periodo della Congregazione dei Riti (1588-1634). Congregazione delle Cause dei Santi sussidi per lo studio delle cause dei santi 7. Vatican City: Urbaniana University Press, 2001.

Patetta, Luciano, and Stefano Della Torre, eds. L'architettura della Compagnia di Gesù in Italia: XVI-XVIII secolo; Atti del convegno Milano, Centro Culturale S. Fedele, 24-27 ottobre 199o. Genoa: Marietti, 1992.

Pecchiai, Pio, s.J. Il Gesù di Roma. Rome: Società Grafica Romana, $195^{2}$.

Pereira, José. The Architecture of Portuguese India. New Delhi: Books \& Books, 1995.

Pereira, José. Churches of Goa. New Delhi: Oxford University Press, 2001. 
Peters, William A.M., S.J. The Spiritual Exercises of St. Ignatius: Exposition and Interpretation. 4th ed. Rome: Centrum Ignatianum Spiritualitatis, 1980 [1967].

Pierce, James Smith. From Abacus to Zeus: A Handbook of Art History. 7 th ed. Upper Saddle River, NJ: Pearson Prentice Hall, 2004 [1968].

Pieterse, Jan Nederveen. Globalization and Culture: Global Mélange. New York: Rowan and Littlefield, 2003 .

Pietrasanta, Sylvestro. De symbolis heroicis libri IX. Antwerp: Plantin Press under Balthasar Moretus, 1634.

Pirri, Pietro, s.J. "L'architetto Bartolomeo Ammannati e i gesuiti." Archivum historicum Societatis Iesu 12 (1943): 5-57.

Pirri, Pietro, s.J. Giovanni Tristano e i primordi della architettura gesuitica. Rome: Institutum Historicum Societatis Iesu, 1955.

Pirri, Pietro, S.J. Giuseppe Valeriano S.I., architetto e pittore 1542-1596. Rome: Institutum Historicum Societatis Iesu, 1970.

Pirri, Pietro, s.J. "Intagliatori gesuiti italiani dei secoli XVI e XVII." Archivum historicum Societatis Iesu 21 (1952): 3-59.

Pirri, Pietro, s.J. "La topografia del Gesù di Roma e le vertenze tra Muzio Muti e S. Ignazio." Archivum historicum Societatis Iesu 10 (1941): 177-217.

Pirri, Pietro, S.J., and Pietro di Rosa, S.J. "Il P. Giovanni de Rosis (1538-1610) e la sviluppo dell'edilizia gesuitica." Archivum historicum Societatis Iesu 44 (1975): 3-104.

Pittau, Giuseppe, s.J. et al., eds. Da Sendai a Roma:Un'ambasceria giapponese a Paolo V. Exhibition catalog. Rome: Museo Nazionale d'Arte Orientale, Museo Nazionale di Castel Sant'Angelo, Museo di Sendai, and Office Move/Associazione Scambi Culturali Internazionali, 199 o.

Poirters, Adriaen, ed. Af-beeldinghe van d'eerste eeuwe der Societeyt Iesu. Antwerp: Plantin Press under Balthasar Moretus, 1640.

Pon, Lisa. "Place, Print, and Miracle: Forli's Madonna of the Fire as Functional Site." Art History 31, no. 3 (June 2008): 303-21.

Pon, Lisa. Printed Icon: Forli's Madonna of the Fire in Early Modern Italy. Cambridge: Cambridge University Press, 2015.

Poncelet, Alfred, s.J. Histoire de la Compagnie de Jésus dans les anciens Pays-Bas: Part 1 , Histoire générale. Brussels: Lamertin, 1926.

Porteman, Karel. Emblematic Exhibitions (Affixiones) at the Brussels Jesuit College (1630-1685): A Study of the Commemorative Manuscripts (Royal Library, Brussels). Brussels and Turnhout: Royal Library and Brepols, 1996.

Porteman, Karel. Inleiding tot de Nederlandse emblemataliteratuur. Groningen: WoltersNoordhoff, 1977.

Porteman, Karel. "The Use of the Visual in Classical Jesuit Teaching and Education." Paedagogica historica 36, no. 1 (2000): 179-96. 
Pozzo, Andrea. Perspectiva pictorum et architectorum. Rome: Jan Jakub Komárek, 1693-1700.

Pozzo, Andrea. Perspective in Architecture and Painting: An Unabridged Reprint of the English-and-Latin Edition of the 1693 Perspectiva pictorum et architectorum. Mineola, NY: Dover Publications, 1989.

Pozzo, Andrea. Shixue. Beijing: Nian Xiyao, 1729.

Praz, Mario. Studies in Seventeenth-Century Imagery. Rome: Edizioni di Storia e Letteratura, 1964.

Preimesberger, Rudolf, Hannah Baader, and Nicola Suthor, eds. Porträt. Geschichte der klassischen Bildgattungen in Quellentexten und Kommentaren 2. Berlin: Dietrich Reimer Verlag, 1999.

Prieto, Beatriz Hernán-Gómez. "Polémica en torno a los orígenes de la arquitectura de los jesuitas y la posible aceptación de un estilo." ma thesis, University of Oviedo, 1976.

Promey, Sally M., ed. Sensational Religion: Sensory Cultures in Material Practice. New Haven: Yale University Press, 2014.

Puhl, Louis J., s.J., ed. The Spiritual Exercises of St. Ignatius: Based on Studies in the Language of the Autograph. Chicago: Newman Press, 1951.

Il quarto centenario della costituzione della Compagnia di Gesù: Conferenze commemorative tenute all'Università Cattolica del Sacro Cuore, 2-11 maggio 1941. Pubblicazioni della Università Cattolica del Sacro Cuore 5. Scienze Storiche 19. Milan: Società Editrice "Vita e Pensiero," 1941.

Rabbow, Paul. Seelenführung: Methodik der Exerzitien in der Antike. Munich: KöselVerlag, 1954.

Rahner, Hugo, s.J. Greek Myths and Christian Mystery. Translated by Brian Battershaw. New York: Biblio \& Tannen Booksellers and Publishers, 1971 [1963].

Rahner, Hugo, s.J. Ignatius the Theologian. Translated by Michael Barry. New York: Herder \& Herder, 1968.

Rahner, Hugo, S.J. The Spirituality of St. Ignatius Loyola: An Account of Its Historical Development. Translated by Francis John Smith, s.J. Westminster: Newman Press, 1953.

Rahner, Karl, s.J. The Dynamic Element in the Church. New York: Herder \& Herder, 1964. Rahner, Karl, s.J. Spiritual Exercises. Translated by Kenneth Baker, s.J. South Bend: St. Augustine's Press and Deutsche Provinz der Jesuiten, 2014 [1967].

Rahner, Karl, s.J. Theological Investigations. London: Darton, Longman \& Todd, 1961-92.

Rasmussen, Steen Eiler. Experiencing Architecture. Cambridge, MA: MIT Press, 1995 [1959].

Réau, Louis. Iconographie de l'art chrétien. 6 Vols. Paris: Presses Universitaires de France, $1955^{-59}$. 
Reese, Thomas, ed. Studies in Ancient American and European Art. New Haven: Yale University Press, 1986.

Rheinbay, Paul, s.A.c. Biblische Bilder für den inneren Weg: Das Betrachtungsbuch des Ignatius-Gefährten Hieronymus Nadal. Egelsbach: Hänsel-Hohenhausen, 1995.

Ribadeneyra, Pedro de. Vida del padre Francisco de Borja. Madrid: Pedro Madrigal, 1592. Ribadeneyra, Pedro de. Vida del padre Ignacio de Loyola, fundador de la religión de la Compañía de Iesus y de los padres maestro Diego Laynezy Francisco de Borja. Madrid: Pedro Madrigal, 1594.

Ribadeneyra, Pedro de. Vita Francisci Borgiae. Antwerp: Joachim Trogney, 1598.

Rickaby, Joseph, s.J., ed. The Spiritual Exercises of St. Ignatius Loyola: Spanish and English with a Continuous Commentary. London: Burns \& Oates, 1915.

Riedl, Peter Anselm. Die Heidelberger Jesuitenkirche und die Hallenkirchen des 17. und 18. Jahrhunderts in Süddeutschland. Heidelberg: Carl Winter, Universitätsverlag, 1956.

Riles, Annelise. The Network Inside Out. Ann Arbor: University of Michigan Press, 200.

Robertson, Clare. Il Gran Cardinale: Alessandro Farnese, Patron of the Arts. New Haven: Yale University Press, 1992.

Rocha, João da. Song nianzhu guicheng. Nanjing: Society of Jesus, [c.1619-23].

Rochard, Patricia, ed. Dem Porträt auf der Spur: Serienbild und Variation in Zeiten der Moderne. Exhibition catalog. Mainz: Internationale Tage/Boehringer Ingelheim, Alten Rathaus der Stadt Ingelheim and Verlag Hermann Schmidt, 2000.

Rooses, Max. "De Plaatsnijders der Evangelicae historiae imagines." Oud Holland 6 (1888): $277-88$.

Rosenthal, Earl. "The Invention of the Columnar Device of Emperor Charles V at the Court of Burgundy in Flanders in 1516." Journal of the Warburg and Courtauld Institutes 36 (1973): 198-23o.

Rosenthal, Earl. "Plus ultra, Non plus ultra, and the Columnar Device of Emperor Charles V." Journal of the Warburg and Courtauld Institutes 34 (1971): 204-28.

Rowland, Ingrid. The Divine Spark of Syracuse. Mandel Lectures in the Humanities. Waltham, MA: Brandeis University Press, 2019.

Sabbe, Maurits. De Meesters van de Gulden Passer: Christoffel Plantin, Aartsdrukker van Philips II, en zijn opvolgers, de Moretussen. Rotterdam: Ad. Donker, 1978.

Sale, Giovanni, s.J. Pauperismo architettonico e architettura gesuitica. Rome:Jaca Book, 2001.

San Juan, Rose Marie. Vertiginous Mirrors: The Animation of the Visual Image and Early Modern Travel. Manchester: Manchester University Press, 2011.

Sardo, Eugenio Lo, ed. Iconismi e mirabilia da Athanasius Kircher. Tecnica Curiosa 2. Rome: Edizioni dell'Elefante, 1999.

Saunders, Alison, and Peter Davidson. eds. Visual Words and Verbal Pictures: Essays in Honour of Michael Bath. Glasgow: Glasgow Emblem Studies, 2005.

Scaduto, Mario, s.J. L'opera di Francesco Borgia 1565-1572. Rome: La Civiltà Cattolica, 1992. 
Schall von Bell, Johann Adam. Jincheng shuxiang. Beijing: Society of Jesus, 1640.

Schamoni, Wilhelm. The Face of the Saints. Translated by Anne Fremantle. New York: Pantheon Books, 1947.

Schepper, Marcus de, and Francine de Nave, eds. Ex officina Plantiniana Moretorum: Studies over het drukkergeslacht Moretus. De Gulden Passer, Special Issue, 74. Antwerp: Vereeniging der Antwerpsche Bibliophielen, 1996.

Scherer, Heinrich. Atlas novus exhibens orbem terraqueum per naturae opera, historiae novae ac veterus monumenta, artisque geographicae leges et praecepts. 7 Vols. Dillingen an der Donau and Frankfurt am Main: August Vindel and Johann Caspar Bencard, 1702-10.

Schroeder, Henry Joseph, O.P., ed. The Canons and Decrees of the Council of Trent. Rev. ed. Charlotte, NC: TAN Books, 1978.

Schütte, Josef Franz, s.J. "Christliche Japanische Literatur, Bilder und Druckblätter in einem unbekannten Vatikanischen Codex aus dem Jahre 1591." Archivum historicum Societatis Iesu 9 (1940): 226-80.

Schurhammer, Georg, s.J., ed. Francis Xavier: His Life, His Times. Translated by M. Joseph Costelloe, s.J. 4 Vols. Rome: Institutum Historicum Societatis Iesu, 1973-82.

Schurhammer, Georg, s.J. Gesammelte Studien. Edited by László Szilas, S.J. 4 Vols. Rome: Institutum Historicum Societatis Iesu, 1963-65.

Schwager, Klaus. "La chiesa del Gesù del Vignola." Bollettino del Centro Internazionale di Studi d'Architettura Andrea Palladio 19 (1977): 251-71.

Sebastian, Santiago. El barroco iberoamericano: Mensaje iconográfico. Madrid: Encuentro, 1990.

Segalen, Victor. Essay on Exoticism: An Aesthetics of Diversity. Edited and translated by Yaël Rachel Schlick. Durham, NC: Duke University Press, 2002 [1978].

Serbat, Louis. "L'architecture gothique des jésuites au XVII ème siècle." Bulletin monumental 66 (1902): 315-70; 67 (1903): 84-134.

Serrão, Vítor. The Legend of Saint Francis Xavier by the Painter André Reinoso: Historical, Aesthetic, and Iconological Study of a Series of Baroque Paintings in the Sacristy of Igreja de São Roque. Translated by Helena Leuschner. Lisbon: Museu de São Roque/ Santa Casa da Misericórdia de Lisboa, 2006.

Serrão, Vítor. A lenda de São Francisco Xavier pelo pintor André Reinoso: Estudo histórico, estético e iconológico de um ciclo barroco existente na Sacristia da Igreja de São Roque. Lisbon: Santa Casa da Misericórdia de Lisboa, 1993.

Serres, Michel, and Bruno Latour. Conversations on Science, Culture, and Time. Translated by Roxanne Lapidus. Ann Arbor: University of Michigan, 1995.

Shimada, Takau, and Yuriko Shimada. Fumie: Gaikokujin ni yoru fumie no kiroku. Tokyo: Yūshōdō Shuppan, 2007 [1994]. 
Shore, Paul, s.J. "The Vita Christi of Ludolph of Saxony and Its Influence on the Spiritual Exercises of Ignatius of Loyola." Studies in the Spirituality of Jesuits 30, no. 1 (January 1998): 1-32.

Sievernich, Michael, s.J., and Günter Switek, S.J., eds. Ignatianisch: Eigenart und Methode der Gesellschaft Jesu. Freiburg im Breisgau: Herder, 1990.

Sigurdson, Richard. Burckhardt's Social and Political Thought. Toronto: University of Toronto Press, 2004.

Sluhovsky, Moshe. Becoming a New Self: Practices of Belief in Early Modern Catholicism. Chicago: University of Chicago Press, 2018.

Sluhovsky, Moshe. "St. Ignatius of Loyola's Spiritual Exercises and Their Contribution to Modern Introspective Subjectivity." Catholic Historical Review 99, no. 4 (October 2013): 649-74.

Smith, Jeffrey Chipps. Sensuous Worship: Jesuits and the Art of the Early Catholic Reformation in Germany. Princeton: Princeton University Press, 2002.

Sors, Anne-Katrin. Allegorische Andachtsbücher in Antwerpen. Göttingen: Universitätsverlag Göttingen, 2015 .

Spence, Jonathan D. The Memory Palace of Matteo Ricci. New York: Penguin, 1984.

Spengler, Dietmar. "Die Ars Jesuitica der Gebrüder Wierix." Wallraf-Richartz-Jahrbuch 57 (1996): 161-94.

Spica, Anne-Elisabeth. "Les jésuites et l'emblématique." XVII ${ }^{e}$ siècle 237 (2007): 633-51.

Spica, Anne-Elisabeth. Symbolique humaniste et emblématique: L'évolution et les genres (1580-1700). Paris: Champion, 1996.

Standaert, Nicolas, s.J. "Chinese Prints and Their European Prototypes: Schall's Jincheng shuxiang." Print Quarterly 23 (2006): 231-53.

Standaert, Nicolas, s.J. "The Composition of Place: Creating Space for an Encounter." The Way 46, no. 1 (January 2007): 7-20.

Standaert, Nicolas, s.J. An Illustrated Life of Christ Presented to the Chinese Emperor: The History of the Jincheng shuxiang (1640). Sankt Augustin: Institut Monumenta Serica, 2007.

Stelling, Lieke, Harald Hendrix, and Todd M. Richardson, eds. The Turn of the Soul: Representations of Religious Conversion in Early Modern Art and Literature. Leiden and Boston: Brill, 2012.

Stijnman, Ad. Engraving and Etching, 1400-2000: A History of the Development of Manual Intaglio Printmaking Processes. Houten: Hes \& De Graaf Publishers, 2012.

Stock, Jan Van der, ed. Hollstein's Dutch and Flemish Etchings, Engravings and Woodcuts, 1450-1700. The Wierix Family. Book Illustrations. Vols. 70-71. 2 Parts. Ouderkerk aan den IJssel: Sound \& Vision Publishers, 2006-7.

Stoichita, Victor I. The Self-aware Image: An Insight into Early Modern Meta-painting. Translated by Anne-Marie Glasheen. Cambridge: Cambridge University Press, 1997. 
Suau, Pierre, s.J. Histoire de Saint François de Borgia, troisième général de la Compagnie de Jésus (1510-1572). Paris: Gabriel Beauchesne \& Cie, 1910.

Sucquet, Antoine. Via vitae aeternae. Vol. 1: Antwerp: Martin III Nuyts, 1620. Vol. 2: Antwerp: Hendrick Aertssens, 1625.

Sylvester, David, ed. Interviews with Francis Bacon. London: Thames and Hudson, 2009 [1987].

Tagita, Kōya. Showa jidai no Senpuku Kirishitan. Tokyo: Nihon Gakujutsu Shinkōkai, 1954.

Tapié, Alain, ed. Baroque, vision jésuite: Du Tintoret à Rubens. Exhibition catalog. Caen: Musée des Beaux-Arts, 2003.

Taussig, Michael. Mimesis and Alterity: A Particular History of the Senses. New York: Routledge, 1993 .

Taylor, John. A Delicate, Dainty, Damnable Dialogue, between the Devill and a Jesuite. London: I.H. [Thomas Banks], 1642.

Telesko, Werner, and Herbert Karner, eds. Die Jesuiten in Wien: Zur Kunst- und Kulturgeschichte der Österreichischen Ordensprovinz der Gesellschaft Jesu im 17. und 18. Jahrhunderts. Vienna: Österreichisches Akademie der Wissenschaften, 2003.

Terhalle, Johannes. S. Andrea al Quirinale von Gian Lorenzo Bernini in Rom. Weimar: Verlag und Datenbank für Geisteswissenschaften, 2011.

Tetlock, Philip E., Richard Ned Lebow, and Geoffrey Parker, eds. Unmaking the West: “What-If?” Scenarios That Rewrite World History. Ann Arbor: University of Michigan Press, 2006.

Torsellino, Orazio. De vita Francisci Xaverii. Antwerp: Joachim Trogney, 1596.

Torsellino, Orazio. De vita Francisci Xaverii. Rome: Luigi Zanetti, 1596.

Traub, George W., s.J., ed. An Ignatian Spirituality Reader: Contemporary Writings on St. Ignatius of Loyola, the Spiritual Exercises, Discernment, and More. Chicago: Loyola Press, 2008.

Tsukahara, Akira. "Kōbe shiritsu hakubutsukan shozō 'Sei furanshisuko zabieruzō' no hozon jyōtai to hyōgen kaishaku." Kōbe shiritsu hakubutsukan kenkyū kiyō 35 (March 31, 2019): 3-19.

Tutino, Stefania. Shadows of Doubt: Language and Truth in Post-Reformation Catholic Culture. Oxford: Oxford University Press, 2014.

Tutino, Stefania. Uncertainty in Post-Reformation Catholicism: A History of Probabilism. Oxford: Oxford University Press, 2018.

Tuttle, Richard J. et al., eds. Jacopo Barozzi da Vignola. Milan: Electa, 2002.

Uribe, Leonardo Ramírez. "El retablo del Rapto de la Iglesia de San Ignacio (Bogotà)." Apuntes 16 (1980): 43-48.

Vallery-Radot, Jean. Le recueil des plans d'édifices de la Compagnie de Jésus conservé à la Bibliothèque National de Paris. Rome: Institutum Historicum Societatis Iesu, 196o. 
Vermeir, Koen. “Athanasius Kircher's Magical Instruments: An Essay on 'Science,' 'Religion' and Applied Metaphysics (1602-1680)." Studies in History and Philosophy of Physics 38, no. 2 (2007): 363-400.

Vermeir, Koen. "The Magic of the Magic Lantern (166o-170o): On Analogical Demonstration and the Visualization of the Invisible." British Journal for the History of Science 38, no. 2 (June 2005): 127-59.

Vermeir, Koen. "Mirror, Mirror, on the Wall: Aesthetics and Metaphysics of 17 thCentury Scientific/Artistic Spectacles." Kritische Berichte 32, no. 2 (2004): 27-38.

Viller, Marcel, s.J., ed. Dictionnaire de spiritualité ascétique et mystique doctrine et histoire. 21 Vols. Paris: Beauchesne, 1937-95.

Virgil. Eclogues, Georgics, Aeneid I-VI. Translated by H. Rushton Fairclough and revised by G.P. Goold. Loeb Classical Library 63. Rev. ed. Cambridge, MA: Harvard University Press, 1999.

Vlam, Grace A.H. "The Portrait of S. Francis Xavier in Kobe." Zeitschrift für Kunstgeschichte 42, no. 1 (1979): 48-6o.

Wadell, Maj-Brit. "The Evangelicae historiae imagines: The Designs and Their Artists." Quaerendo 10 (1980): 279-91.

Wadell, Maj-Brit. Evangelicae historiae imagines: Entstehungsgeschichte und Vorlagen. Gothenburg Studies in Art and Architecture 3. Gothenburg: Eric Lindgrens Boktryckeri, 1985 .

Wakakuwa, Midori. Seibozō no tōrai. Tokyo: Seidosha, 2008.

Wang, Lianming. Jesuitenerbe in Peking: Sakralbauten und transkulturelle Räume, 160o1800. Heidelberg: Universitätsverlage Winter, 2020.

Warnke, Martin. "Italienische Bildtabernakel bis zum Frühbarock." Münchner Jahrbuch der bildenden Kunst 19 (1968): 61-102.

Weibel, Walther. Jesuitismus und Barockskulptur in Rom. Strassburg: Heitz \& Mündel, 1909.

Weil, Simone. Gravity and Grace. Translated by Emma Crawford and Mario von der Ruhr. London: Routledge, 2002.

Weinstein, Donald, and Rudolph M. Bell. Saints \& Society: The Two Worlds of Western Christendom, 1000-1700. Chicago: University of Chicago Press, 1982.

Weisbach, Werner. Der Barock als Kunst der Gegenreformation. Berlin: P. Cassirer, 1921. Weston, Victoria, ed. Portugal, Jesuits, and Japan: Spiritual Beliefs and Earthly Goods. Exhibition catalog. Boston: McMullen Museum of Art, Boston College, 2013.

Weststeijn, Thijs, Eric Jorink, and Frits Scholten, eds. Netherlandish Art in Its Global Context. Nederlands Kunsthistorisch Jaarboek 66. Leiden and Boston: Brill, 2016.

Whelan, Christal, ed. The Beginning of Heaven and Earth: The Sacred Book of Japan's Hidden Christians. Honolulu: University of Hawai'i Press, 1996. 
Wilt, Adrianus de, s.J. "Enkele leden van de familie Plantin en de Annuntiaten." De Gulden Passer 38 (1960): 140-50.

Winckelmann, Johann Joachim. Geschichte der Kunst des Altertums. Dresden: Walther, 1764 .

Winckelmann,JohannJoachim. The Historyof Ancient Art. Translated by G. Henry Lodge. Boston: Houghton Mifflin, 188o.

Wittkower, Rudolf, and Irma B. Jaffe, eds. Baroque Art: The Jesuit Contribution. New York: Fordham University Press, 1972.

Wolf, Gerhard. "Porta Regina, Cappella Ferreri und die 'Imagines supra Portam': Ein Ort und seine Bilder in Santa Maria Maggiore zu Rom." Arte medievale, 2nd series, 5, no. 1 (1991): 117-53.

Wolf, Gerhard. Salus Populi Romani: Die Geschichte römischer Kultbilder im Mittelalter. Weinheim: vcH, Acta Humaniora, 199 o.

Wölfflin, Heinrich. Kunstgeschichte Grundbegriffe: Das Problem der Stilentwicklung in der neueren Kunst. Munich: Friedrich Bruckmann, 1915.

Wölfflin, Heinrich. Principles of Art History: The Problem of the Development of Style in Later Art. Translated by Marie D.M. Hottinger. New York: Dover, 1950.

Wolk-Simon, Linda, ed. The Holy Name: Art of the Gesù; Bernini and His Age. Early Modern Catholicism and the Visual Arts 17. Exhibition catalog. Philadelphia: St. Joseph's University Press, 2018.

Worcester, Thomas, s.J., ed. The Cambridge Companion to the Jesuits. Cambridge: Cambridge University Press, 2008.

Worcester, Thomas, s.J., ed. The Cambridge Encyclopedia of the Jesuits. Cambridge: Cambridge University Press, 2017.

Zamora, María Isabel Álvaro, Javier Ibáñez Fernández, and Jesús Criado Mainar, eds. La arquitectura jesuítica: Actas del simposio internacional celebrado en Zaragoza el 9, 10, y 11 de diciembre de 2010. Zaragoza: Institución "Fernando el Católico," 2012.

Zierholz, Steffen. "Conformitas crucis Christi: Zum Motiv der Kreuzesnachfolge in der jesuitischen Druckgrafik des 17. Jahrhunderts im Licht der Vision von La Storta.” Archivum historicum Societatis Iesu 86 (2017): 49-97.

Zierholz, Steffen. Räume der Reform: Kunst und Lebenskunst der Jesuiten in Rom, 1580170o. Berlin: Gebr. Mann Verlag, 2019.

Županov, Ines G., ed. The Oxford Handbook of the Jesuits. Oxford: Oxford University Press, 2019. 